\title{
AVALIAÇÃO DA NEBULIZAÇÃO E ABERTURA DE CORTINAS NA REDUÇÃO DA TEMPERATURA DO AR EM AMBIENTE PROTEGIDO
}

RAQUEL APARECIDA FURLAN

Tese apresentada à Escola Superior de Agricultura "Luiz de Queiroz", Universidade de São Paulo, para obtenção do título de Doutor em Agronomia, Área de Concentração: Irrigação e Drenagem.

PIRACICABA

Estado de São Paulo - Brasil

Janeiro - 2001 


\title{
AVALIAÇÃO DA NEBULIZAÇÃO E ABERTURA DE CORTINAS NA REDUÇÃO DA TEMPERATURA DO AR EM AMBIENTE PROTEGIDO
}

\section{RAQUEL APARECIDA FURLAN}

Engenheiro Agrônomo

\author{
Orientador: Prof. Dr. MARCOS VINÍCIUS FOLEGATTI
}

Tese apresentada à Escola Superior de Agricultura "Luiz de Queiroz", Universidade de São Paulo, para obtenção do título de Doutor em Agronomia, Área de Concentração: Irrigação e Drenagem.

PIRACICABA

Estado de São Paulo - Brasil

Janeiro - 2001 
Dados Internacionais de Catalogação na Publicação (CIP) DIVISÃO DE BIBLIOTECA E DOCUMENTAÇÃO - Campus "Luiz de Queiroz"/USP

Furlan, Raquel Aparecida

Avaliação da nebulização e abertura de cortinas na redução da temperatura do ar em ambiente protegido / Raquel Aparecida Furlan. - Piracicaba, 2001.

146 p. : il.

Tese (doutorado) - Escola Superior de Agricultura Luiz de Queiroz, 2001. Bibliografia.

1. Cultivo protegido 2. Efeito de temperatura 3. Estufa 4. Nebulização 5. Redução 6. Temperatura do ar I. Título 
Aos meus pais, Edenir Pedro Furlan e Maria de Lourdes G. Furlan, e a Rosni Parolina pelo apoio, amor e incentivo durante toda essa etapa da minha vida,

Dedico e Ofereço 


\section{AGRADECIMENTOS}

A Deus, pela minha vida.

À Escola Superior de Agricultura "Luiz de Queiroz" - ESALQ/USP - através do Departamento de Engenharia Rural, pela oportunidade de realizar o curso de pósgraduação.

Ao professor orientador Dr. Marcos Vinícius Folegatti, por ter participado durante todo o processo de elaboração e execução desse trabalho sempre com muita dedicação, incentivo e amizade.

À Coordenação de Aperfeiçoamento de Pessoal de Nível Superior - CAPES, pela concessão da bolsa de estudos.

A todos os professores do departamento de Engenharia Rural e departamento de Ciências Exatas da ESALQ, pela colaboração e atenção sempre dispensada, em especial aos Professores Nilson Augusto Villa Nova, Paulo César Sentelhas e Prof. Iran J. O. Silva, pela disponibilidade para esclarecer dúvidas, pelas sugestões e cordialidade.

À Regina Célia Matos Pires, pelas sugestões e pela amizade.

Aos amigos Luis Fernando S. M. Campeche, Fabiano Chaves da Silva e Alexandre B. Heinemann, pela colaboração na execução desse trabalho.

Aos amigos Adriana Ramos, Nádia F. Rossi, Tamara M. Gomes, Fátima C. Rezende, Renata Furlan, Roberta Furlan Marcchiori, Selma Magiotto, Enio Faria França e Silva, Vital Pedro S. Paz, Leonardo Duarte B. Silva, Jarbas Honório de Miranda e Adriano J. Soares, pelos bons momentos de convivência e amizade. 
Aos funcionários do Departamento de Engenharia Rural, Gilmar Batista Grigolon, Hélio Toledo Gomes, Antônio César Souza Rocha, Antonio Gozzo, Juarez R. Amaral, Vanda Macedo Zambello, Sandra Regina Thompson Silveira Mello e Davilmar Aparecida Domingues Collevatti, Vera Lúcia José Miguel e aos ex-funcionários José Figueiredo e Adilson A. Rodrigues.

Aos colegas e amigos do curso de pós-graduação em Irrigação e Drenagem pelo convívio sempre enriquecedor.

A todos aqueles que contribuíram em qualquer etapa para a realização deste trabalho. 


\section{SUMÁRIO}

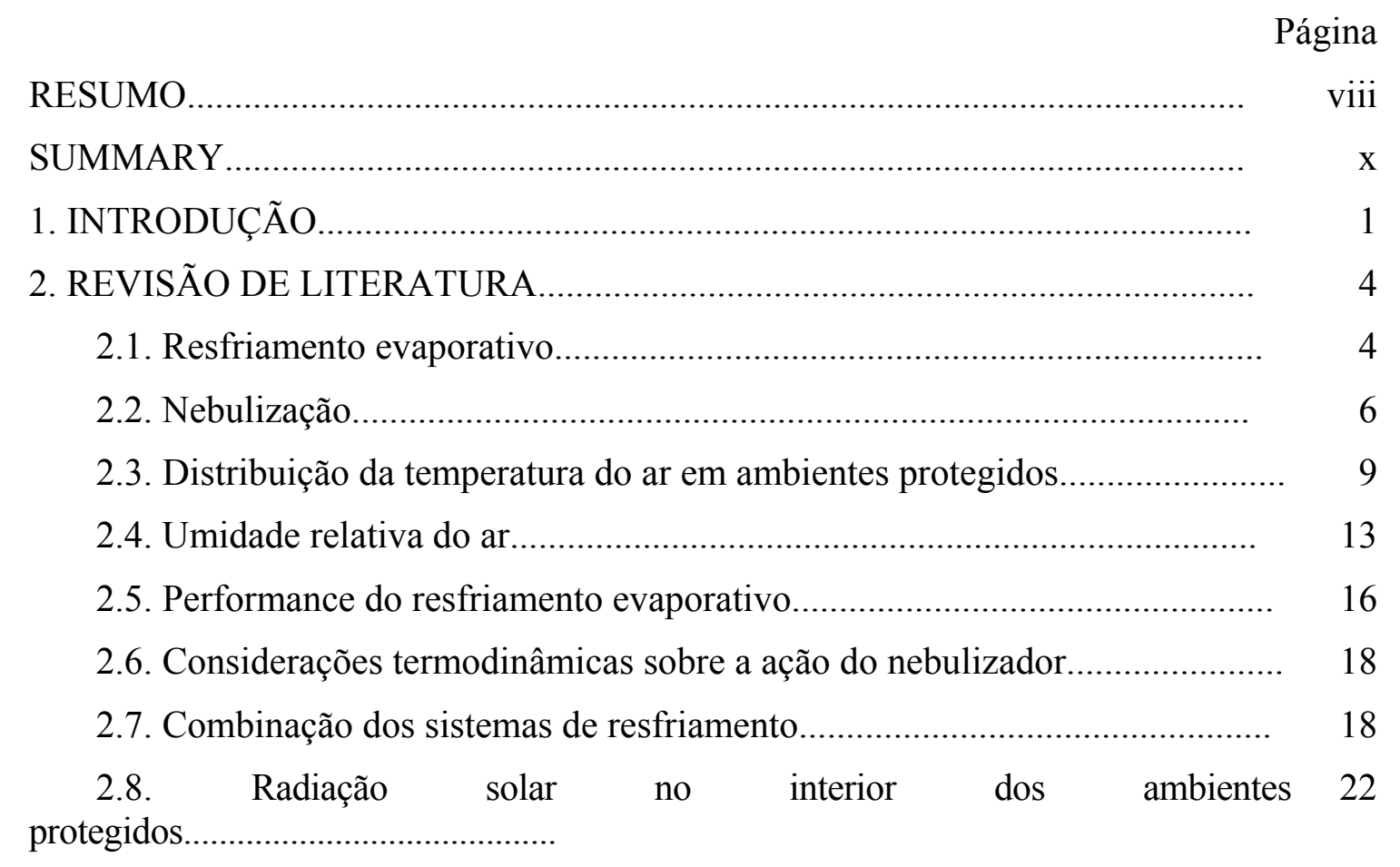

2.9. Efeito estufa................................................................................................. 23

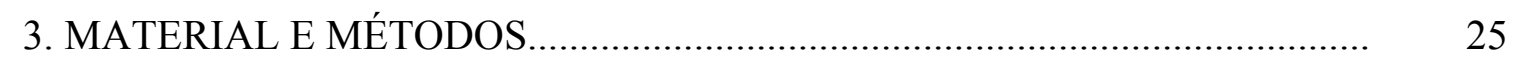

3.1. Caracterização do local e período de experimentação............................... 25

3.2. Variáveis meteorológicas internas e externas.......................................... 27

3.2.1. Temperatura do ar no ambiente protegido..................................... 27

3.2.2. Umidade relativa do ar no ambiente protegido.............................. 29

3.2.3. Radiação solar e fluxo de calor no solo no ambiente 30 protegido..........

3.2.4. Variáveis meteorológicas externas............................................... 31

3.3. Sistema de nebulização........................................................................ 31

3.4. Distribuição vertical e horizontal de temperatura do ar (isotermas) em ambientes protegidos. 
3.5. Manejo de cortinas e nebulização no ambiente protegido.......................... 33

3.6. Utilização de água a diferentes temperaturas............................................ 35

4. RESULTADOS E DISCUSSÃO.............................................................. 37

4.1. Variação da temperatura e umidade relativa do ar e da radiação líquida....................................................................................... 37

4.2. Efeito do manejo de cortinas e nebulização em ambientes 42 protegidos..........

4.2.1. Efeito da abertura de cortinas laterais e zenitais na temperatura do

ar

4.2.1.1. Variação da temperatura do ar......

4.2.1.2. Variação vertical e horizontal de temperatura do ar.

4.2.2. Nebulização e redução da temperatura do ar no ambiente protegido.

4.2.2.1. Cortinas fechadas......................................................... 50

4.2.2.1.1. Variação da temperatura do ar............................ 50

4.2.2.1.2. Variação vertical e horizontal de temperatura do ar.

4.2.2.2. Cortinas laterais abertas.................................................. 58

4.2.2.2.1 Distribuição temporal de temperatura do ar........... 58

4.2.2.2.2. Variação vertical e horizontal de temperatura do ar.

4.2.3. Efeito da abertura das cortinas e da nebulização na redução da temperatura do ar nos ambientes protegidos

4.2.3.1. Cortinas laterais abertas a $1,0 \mathrm{~m}$ de altura em relação ao nível solo.

4.2.3.1.1. Variação da temperatura do ar.

4.2.3.1.2. Variação vertical e horizontal de temperatura do

ar

4.2.3.2. Cortinas laterais abertas a 2,0m de altura em relação ao nível solo. 
4.2.3.2.2. Variação vertical e horizontal de temperatura do ar.

4.2.4. Efeito da abertura de cortinas zenitais, com diferentes alturas de abertura de cortinas laterais.

4.2.4.1. Cortinas laterais abertas a $0,5 \mathrm{~m}$ de altura

4.2.4.1.1. Variação da temperatura do ar.

4.2.4.1.2. Variação vertical e horizontal de temperatura do ar........

4.2.4.2. Cortinas laterais abertas a $1,0 \mathrm{~m}$ de altura

4.2.4.2.1. Variação da temperatura do ar.

4.2.4.2.2. Variação vertical e horizontal de temperatura do ar.

4.2.4.3. Cortinas laterais abertas a 2,0m de altura

4.2.4.3.1. Variação da temperatura do ar.

4.2.4.3.2. Variação vertical e horizontal de temperatura do ar.

4.2.4.4. Cortinas laterais abertas a 3,0m de altura

4.2.4.4.1. Variação da temperatura do ar.

4.2.4.4.2. Variação vertical e horizontal de temperatura do ar.

4.2.5. Abertura de cortinas laterais a diferentes alturas.

4.2.5.1. Abertura da cortina lateral a $2,5 \mathrm{~m}$ comparada com abertura a 1,0m de altura em relação ao nível do solo.

4.2.5.1.1. Variação da temperatura do ar.

4.2.5.1.2. Variação vertical e horizontal de temperatura do ar.

4.2.5.2. Abertura das cortinas laterais abertas a $2,5 \mathrm{~m}$ comparada com abertura da cortina lateral aberta a $1,0 \mathrm{~m}$ de altura e nebulização.

4.2.5.2.1. Variação da temperatura do ar.

4.2.5.2.2. Variação vertical e horizontal de temperatura do ar.

4.2.6. Efeito da utilização de água resfriada na 133 nebulização. 


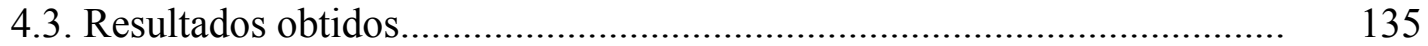

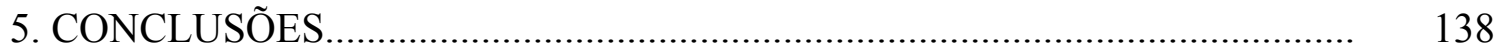

6. REFERÊNCIAS BIBLIOGRÁFICAS........................................................ 140 


\title{
AVALIAÇÃO DA NEBULIZAÇÃO E ABERTURA DE CORTINAS NA REDUÇÃO DA TEMPERATURA DO AR EM AMBIENTE PROTEGIDO
}

\author{
Autor: RAQUEL APARECIDA FURLAN \\ Orientador: PROF. DR. MARCOS VINÍCIUS FOLEGATTI
}

\section{RESUMO}

O objetivo geral desse trabalho foi o de avaliar o efeito de diferentes manejos de cortinas e sistemas de resfriamento na redução da temperatura do ar interna de ambientes protegidos. Esse trabalho foi realizado em ambientes protegidos com solo nu na área experimental do Departamento de Engenharia Rural, da Escola Superior de Agricultura "Luiz de Queiroz", da Universidade de São Paulo em Piracicaba, SP. Os ambientes protegidos foram instalados no sentido leste-oeste, com dimensões de $6,4 \mathrm{~m}$ de largura por 17,5 m de comprimento. A avaliação da distribuição espacial da temperatura do ar (em graus centígrados) no interior do ambiente protegido foi avaliada através da medição com termopares (cobre-constantã) instalados formando malhas, com espaçamento horizontal entre eles de 3,0m e nas alturas de $0,5 \mathrm{~m}, 1,0 \mathrm{~m}, 2,0 \mathrm{~m}, 3,0 \mathrm{~m}$ e $4,0 \mathrm{~m}$ em relação ao solo, constituindo um conjunto de 78 pontos de amostragem. Os valores de temperatura do ar foram armazenados em um sistema de aquisição de dados. A nebulização em ambientes protegidos mostrou-se eficaz no processo de redução de temperaturas do ar durante o seu acionamento. A combinação do manejo de cortinas e nebulização foi o sistema mais eficiente na redução de temperatura do ar e pode reduzir 
a temperatura do ar no ambiente protegido a níveis muito próximos à temperatura do ar externa e em alguns casos a temperaturas abaixo da mesma. O efeito na redução de temperatura média do ar no ambiente protegido causado pela abertura da janela zenital foi maior com a menor abertura das cortinas laterais devido ao processo convectivo ou "efeito termo-sifão". A distribuição da temperatura média do ar no ambiente protegido com as cortinas laterais abertas a 3,0m de altura praticamente não foi modificada pela abertura da cortina zenital, principalmente quando a velocidade de vento externo era superior a 2,0m/s. A análise da distribuição da temperatura do ar por meio de isotermas permitiu uma visão global instantânea do processo de redução de temperatura do ar. Através das isotermas observou-se que a distribuição de temperatura do ar no ambiente protegido não é homogênea e a escolha do local ideal para instalação de sensores para medidas dos elementos meteorológicos é um aspecto importante a ser considerado. Nesse estudo, o sensor que correspondeu a medida de temperatura média do ar no ambiente protegido com as cortinas laterais fechadas estava localizado no centro do ambiente protegido, a 1,0m de altura em relação ao nível do solo. 


\title{
EVALUATION OF FOG AND HANDLING CURTAINS TO REDUCE AIR TEMPERTAURE IN A PLASTIC GREENHOUSE
}

\author{
Author: RAQUEL APARECIDA FURLAN \\ Adviser: PROF. DR. MARCOS VINÍCIUS FOLEGATTI
}

\section{SUMMARY}

The objective of this study was to evaluate different managements, such as fog and handling curtains, to reduce air temperature in a plastic greenhouse. The experiment was conducted in two plastic greenhouses installed in an East-West direction and located at the Department of Rural Engineering, "Escola Superior de Agricultura Luiz de Queiroz”, University of São Paulo, Piracicaba, São Paulo State. The plastic greenhouses have a dimension of $6.4 \mathrm{~m}$ width and $17.5 \mathrm{~m}$ of length. The air temperature $\left({ }^{\circ} \mathrm{C}\right)$ spatial distribution was measured using 78 thermopar sensors installed in a grid of $3.0 \mathrm{~m}$ horizontally and five different high, 0.5, 1.0, 2.0, 3.0 and 4.0m. The sensors were connected to a data logger system and the data were stored there. The fog system showed a good efficiency to decrease the greenhouse air temperature. A combination of fog system and handling curtains was the most efficient management to decrease the plastic greenhouse air temperature. Due to the convection process, the opened of zenith curtains showed efficient to decrease the plastic greenhouse temperature only when the side curtains is not totally opened. The air temperature distribution was not modified when the side curtains were opened from $3.0 \mathrm{~m}$ of the soil and the wind speed outside was higher than $2.0 \mathrm{~m} / \mathrm{s}$. 
Isotherms lines were determined and described the spatial distribution of plastic greenhouse air temperature. Through the isotherms lines were observed that the spatial distribution of plastic greenhouse air temperature was not homogeneous. Due to this fact, the places to install the sensors are an important factor to be considered. In this study, the sensor that showed the average value of greenhouse air temperature was located in the middle of the plastic greenhouse, and $1.0 \mathrm{~m}$ of high. 


\section{INTRODUÇÃO}

De acordo com Bliska Jr. \& Honório (1996), cultivo protegido e plasticultura são termos que se confundem devido ao material industrializado à base de plástico empregado no auxílio da produção agrícola. O termo plasticultura é um termo inadequado que se consagrou para definir o uso do plástico na agricultura, como revestimento para canais de irrigação, lonas para silos, embalagens de transporte e comercialização, mulching, estufas, etc. Já cultivo protegido representa a técnica de proteção contra intempéries climáticas como a chuva e o vento.

Em 1951 surgiu no Japão, o primeiro filme de PVC para emprego agrícola. Mais tarde, em 1955, as películas de PVC foram utilizadas na fumigação de solo e silagem forrageira. Em 1958, a França iniciou experiências com abrigos e cobertura morta de solo usando filmes de polietileno de baixa densidade (PEBD). Os pequenos túneis deram certo e rapidamente se espalharam em todo o mundo ficando conhecidos como "túneis de Nantes", por terem sido desenvolvidos na cidade de Nantes. A partir de então a utilização do plástico nas atividades agrícolas assumiu grande importância e suas aplicações se diversificaram.

No Brasil, a utilização do polietileno na agropecuária passou a ser pesquisada, experimentada e difundida a partir de 1970, num trabalho conjunto entre iniciativa privada e órgãos oficiais de pesquisa agrícola e extensão rural, originando o aparecimento de uma tecnologia nacional, própria para a solução de nossos problemas rurais, levando

obviamente em consideração nossas condições climáticas e práticas agrícolas em uso (Siqueira, 1996 e Goto, 1993).

A partir dos anos 80, houve grande desenvolvimento da plasticultura nacional. Anteriormente usada sobretudo para a produção de flores, essa técnica passou a fazer parte 
também da produção de alimentos, basicamente hortaliças, como alface, abobrinha, pepino, melão, pimentão, feijão-vagem, tomate e morango. De acordo com levantamento efetuado em 1999, cerca de 1390ha foram cultivados com hortaliças em ambientes protegidos no Brasil no ano de 1998. São Paulo, Paraná e Rio Grande do Sul foram os estados com maior área de produção. Dentre as hortaliças mais cultivadas destacaram-se o pimentão, a alface, o tomate e o pepino. Na área científica, a utilização de ambientes protegidos ocupava um espaço de 40ha aproximadamente (Vecchia \& Koch, 1999).

Nas Regiões Sul e Sudeste, principalmente no Estado de São Paulo, tem ocorrido grande interesse de produtores em busca de novas tecnologias para o cultivo em ambiente protegido por se mostrarem vantajoso, possibilitando o aumento da produtividade, melhor qualidade dos produtos, produção fora de épocas convencionais e melhor preço.

Entre as culturas cultivadas em ambiente protegido destaca-se a floricultura como a atividade que mais tem investido em tecnologia de produção no país, devido principalmente ao alto valor econômico que este produto atinge e do elevado nível de exigência do mercado consumidor.

Sendo assim, com o cultivo de flores e hortaliças em ambiente protegido em pleno crescimento, a demanda por informações tecnológicas de manejo nas nossas condições climáticas é crescente.

Um aspecto a ser estudado sobre o cultivo em ambiente protegido nas regiões tropicais e subtropicais é a atenuação de altas temperaturas que são prejudiciais ao crescimento e produção de algumas culturas. Em geral, altas temperaturas do ar no interior de ambientes protegidos, diminui o rendimento e a qualidade dos produtos, chegando a produzir, em alguns casos extremos a morte de plantas.

O objetivo geral desse trabalho foi o de avaliar o efeito de diferentes manejos de cortinas e sistemas de resfriamento na redução da temperatura do ar interna de ambientes protegidos.

Os objetivos específicos desse trabalho foram o de analisar a influência de:

- Diferentes alturas das aberturas de cortinas laterais na redução da temperatura do ar interna; 
- Abertura e fechamento da janela zenital na redução da temperatura do ar interna;

- Sistema de resfriamento adiabático evaporativo na redução da temperatura do ar interna;

- Sistema de resfriamento adiabático evaporativo, com água resfriada, na redução da temperatura do ar interna;

- Manejos combinados e interativos na redução da temperatura do ar interna. 


\section{REVISÃO DE LITERATURA}

\subsection{Resfriamento evaporativo.}

Os sistemas de resfriamento evaporativo consistem em mudar o ponto do estado psicrométrico do ar para maior umidade e menor temperatura, mediante o contato do ar com uma superfície umedecida ou líquida, ou com água aspergida ou pulverizada. Como a pressão de vapor do ar insaturado a ser resfriado é menor que a da água de contato, ocorre a vaporização da água (Wiersma \& Short, 1983). O calor necessário para esta mudança de fase, de água líquida para vapor d’água, é cedido pelo ar que apresenta, então, decréscimo em sua temperatura. O calor requerido para a vaporização da água é fornecido pelo ar, com redução do calor sensível do mesmo e aumento do calor latente da água, sendo mantida constante a entalpia do sistema (Fehr et al., 1982) e aumentando a quantidade de vapor de água (Montero et al., 1990). O resfriamento evaporativo é um processo adiabático, ou seja, não há nenhum ganho ou perda de calor e, portanto, a energia requerida para evaporar a água é suprida pelo ar com conseqüente umidecimento do ar insaturado e redução da temperatura de bulbo seco (Abreu et al., 1999). De acordo com Baêta \& Souza (1997) em um resfriamento evaporativo adiabático, nenhum calor externo é adicionado durante o processo e o conteúdo total de calor não varia. Há simplesmente uma mudança adiabática de calor sensível para calor latente, porém, ocasionando uma mudança ambiental que melhora de forma considerável as condições de conforto.

A eficiência de aplicação do sistema de resfriamento evaporativo depende da diferença entre as temperaturas do bulbo seco e do bulbo úmido (depressão 
psicrométrica) observada na região. Em regiões com depressão psicrométrica variando de 7,0 a $9,0^{\circ} \mathrm{C}$, foram observadas quedas de temperatura de 4,0 a $7,0^{\circ} \mathrm{C}$, enquanto que, para depressões de 14,0 a $17,0^{\circ} \mathrm{C}$, as quedas de temperatura variaram de 8,0 a $11,0^{\circ} \mathrm{C}$ (Whitaker, 1979).

Montero et al. (1990) estudaram o efeito do sistema de resfriamento por nebulização no ambiente gerado pelo ambiente protegido, durante o verão de 1989 . Os dois ambientes protegidos usados no experimento foram cobertos com um filme multiEVA e uma tela de sombreamento aluminizada transmitindo 45,0\% da radiação solar incidente, tendo as dimensões de 19,2 x 12,0m. O sistema de nebulização foi instalado em um dos ambientes protegidos utilizando-se 26 bocais. Nos dois ambientes protegidos foram cultivados Cyclamen persicum. Os resultados mostraram que o resfriamento evaporativo dos ambientes protegidos abaixou sua temperatura do ar em $3,0^{\circ} \mathrm{C}$ na média, quando se comparou com o ambiente protegido controle. A redução máxima de temperatura durante dias de sol foi de $5,0^{\circ} \mathrm{C}$, com conseqüente aumento da umidade relativa, que se manteve em $85,0 \%$ nos ambientes com sombreamento.

Para o correto manejo das culturas em ambientes protegidos, é preciso estudar a evapotranspiração das principais culturas cultivadas nesta condição, uma vez que a evapotranspiração é um componente importante no balanço de energia diário. Neste aspecto, comentam Montero et al. (1990), a cultura de Cyclamen, por exemplo, absorve cerca de $16,0 \%$ da radiação líquida no processo de evapotranspiração, enquanto que a cultura do tomate absorve cerca de 50,0\%.

A ventilação natural e o resfriamento por nebulização são processos que afetam a energia armazenada em ambientes protegidos. Se a renovação de ar é elevada, pode-se chegar a uma elevada transpiração das plantas levando-as ao estresse e se a renovação de ar for baixa não há trocas com o ambiente externo, ocorrendo uma condição de elevada umidade relativa o que pode ser desfavorável à cultura pela redução da transpiração e pelo aumento de doenças (Baille ${ }^{1}$, citado por Montero et al. 1990)

\footnotetext{
${ }^{1}$ BAILLE, A. La climatisation des serres en periode estivale. Sem. AGRO-VETP. Athénes. P. 14-18, november, 1988.
} 
Montero \& Antón (1994), relatam quatro fatores que influenciam a redução de temperatura: ventilação ou renovação do ar, evapotranspiração da cultura, radiação solar e evaporação de água dentro do ambiente protegido. Uma equação simplificada deste processo pode ser escrita, como a seguir:

Rint + Hci $=$ Vent + LE + Evap

Em que:

Rint: energia solar transmitida e absorvida no ambiente protegido

Hci: calor transferido por condução para o ar do ambiente protegido pela cobertura

Vent: energia transferida do ambiente protegido por ventilação

LE: energia usada na transpiração da cultura

Evap: energia consumida para evaporar água do dispositivo de resfriamento evaporativo.

Os principais sistemas de resfriamento evaporativo, consistem basicamente dos sistemas de "pad cooling" ou "pad fan" e nebulização (baixa e alta pressão). Os sistemas de "pad cooling" ou "pad fan" requerem ventilação mecânica para forçar o ar através dos painéis evaporativos e nos sistemas de nebulização podem ser empregados a ventilação natural ou mecânica. Os painéis evaporativos são geralmente de material especial de celulose ou argila expandida, mantidos constantemente umedecidos, através do qual o ar passa e resfria-se antes de entrar no ambiente. Alguns produtores utilizam o sistema de aspersão sobre a cobertura para minimizar o efeito da carga térmica radiante (Abreu, 1999).

\subsection{Nebulização}

A principal vantagem do sistema de resfriamento por nebulização é a uniformidade de resfriamento em todo o ambiente, eliminando a necessidade de ventilação de ar forçada, resultando em um resfriamento mais efetivo e de fácil adaptação em ambiente protegido. Entretanto, apresenta as desvantagens de ter um custo 
de instalação alta, necessidade do uso de água de qualidade excelente, aumento da ferrugem nas estruturas metálicas e nos equipamentos do ambiente protegido. Montero \& Antón (1994), salientam também que o tamanho da gota é muito importante e que deve ter no máximo 10 microns de diâmetro para evitar o problema de molhamento das plantas. Uma das vantagens do sistema de resfriamento por nebulização citado por Alpi \& Tognoni (1991), é que este sistema permite o resfriamento em ambientes protegidos sem a necessidade de criar sombra e ao mesmo tempo permite baixas temperaturas e fortes intensidades de luz, permitindo no verão, boas condições para muitas espécies de plantas, tanto ornamentais como hortícolas.

Montero \& Antón (1994) comparando a temperatura do ar externo e interno de ambientes protegidos similares, observaram que em um dia de verão em Barcelona, com umidade relativa média de 59,0\%, ao meio dia, a temperatura no ambiente protegido com nebulização era 2,0 a $3,0^{\circ} \mathrm{C}$ menor que o ambiente externo, enquanto que no ambiente protegido controle era aproximadamente $6,0^{\circ} \mathrm{C}$ acima da temperatura externa.

A eficiência do sistema de nebulização claramente diminui em áreas úmidas (Montero \& Antón, 1994; Fang, 1995). Os valores de umidade relativa do ar no interior dos ambientes protegidos são muito variáveis e estão intimamente relacionados aos valores de temperatura do ar. Assim, para um mesmo conteúdo de vapor de água no ar, a umidade relativa é inversamente proporcional à temperatura (Seeman, 1979). A ocorrência de chuva, por sua vez, elevaria a concentração de vapor de água no ambiente, elevando a tensão de vapor e a umidade relativa do ar e diminuindo o déficit de saturação. Desta forma, o efeito de resfriamento por evaporação ficaria reduzido.

Entretanto, o resfriamento por evaporação é o mais efetivo método para baixar a temperatura do ar, tanto em ambientes protegidos em áreas secas como em áreas úmidas durante as primeiras fases do desenvolvimento da cultura (Montero \& Antón, 1994).

Em Taiwan, onde a umidade relativa é continuamente alta, o manejo de ambiente protegido adotado é o de manter a taxa de renovação de ar por ventilação de 1,5 volumes por minuto (Fang, 1995). 
Considerando-se a inter-relação entre os fatores que afetam a temperatura do ar do ambiente protegido, o controle ambiental durante as horas de sol é difícil. Dos quatro fatores básicos que afetam a temperatura do ar a radiação solar interna e a adição de umidade por evaporação de água são facilmente medidos ou calculados mas a taxa de ventilação e a taxa de transpiração apresentam certas dificuldades de quantificação. A precisão diminui à medida que não sabemos corretamente a taxa de ventilação externa ao ambiente e da mesma forma desconhecemos a taxa de consumo de água das culturas em uma escala curta de tempo (Montero \& Antón, 1994). Da mesma forma, Farias et al. (1993), observaram que o efeito da cobertura plástica sobre a temperatura e umidade relativa do ar está intimamente relacionado com as condições atmosféricas do ambiente externo. Assim, em dias chuvosos ou nublados ou de ventos fortes e frios, o efeito da nebulização sobre a redução de temperatura no interior de ambientes protegidos, será menor que em dias claros de céu aberto e de alta incidência de radiação solar.

O sistema com nebulização tem a mais alta eficácia entre todos os métodos de resfriamento evaporativo se a eficiência do bocal for alta e se a vazão e a pressão estiverem de acordo com as recomendações do fabricante, de forma que haja garantia de um bom desempenho do sistema. Entretanto, o sistema apresenta desvantagens tais como, requerer alta qualidade da água, alta pressão da bomba, alta qualidade dos bocais, conduzindo a um alto custo operacional e inicial. $\mathrm{O}$ atomizador trouxe a alternativa de introduzir uma boa qualidade de névoa sem as desvantagens mencionadas acima, no entanto, precisa operar com ventiladores exaustores e recirculadores para promover a troca de ar (Fang, 1995).

Al-Jamal (1994) analisando a distribuição temporal da temperatura do ar no interior do ambiente protegido comercial equipado com sistema de resfriamento evaporativo "pad" no sudoeste da Jordânia, constatou que em ambiente protegido fechado, a temperatura do ar não coincide com a temperatura ambiente máxima, devido a distribuição da radiação solar durante o dia. Constatou que para condição de mesma umidade relativa, houve maior resfriamento quanto maior a taxa de renovação de ar e que para uma mesma taxa de renovação de ar, houve maior resfriamento do ar com menor umidade relativa. 
2.3. Distribuição da temperatura em ambientes protegidos

Vários fatores influenciam a temperatura do ar em ambientes protegidos tais como: ângulo de incidência da radiação solar, tipo de cobertura plástica, tipo de solo, tamanho e volume do ambiente protegido (Seeman, 1979). Al-Jamal (1994), acrescenta que a temperatura do ar no interior do ambiente protegido é também função da hora do dia e da distribuição de radiação solar durante o dia.

A temperatura do ar no interior do ambiente protegido está intimamente ligada ao seu balanço de energia. Depende, portanto, dos processos de incidência da radiação solar, reflexão e reirradiação pelos objetos no interior do ambiente protegido, condução através da cobertura e paredes, renovação do ar e troca de calor com o solo (Farias et al., 1993). Desta forma, características que afetam tais processos de ganho e perda de energia, como volume de ar do ambiente protegido, condição atmosférica externa, área da superfície coberta, também condicionarão a temperatura do ar em ambientes protegidos.

Na região Sudeste, Faria Júnior et al. (1993) não encontraram diferenças entre ambiente protegido tipo capela e tipo teto em arco, cobertas com PEBD $75 \mu$, quanto à temperatura média, mínima e máxima, que foram, em média de $32,2^{\circ} \mathrm{C}, 21,8^{\circ} \mathrm{C}$ e $40,7^{\circ} \mathrm{C}$, respectivamente. Entretanto, os ambientes protegidos proporcionaram maiores temperaturas máximas em comparação com o ambiente externo. Pezzopane et al. (1992) também verificaram no inverno maiores temperaturas máximas no interior do ambiente protegido, com amplitude térmica entre o interior e o exterior de aproximadamente $6,0^{\circ} \mathrm{C}$. Folegatti et al. (1997) observaram que, na primavera, os valores das temperaturas máxima, média e mínima do ar dentro do ambiente protegido foram sempre superiores aos do exterior $(14,8 \%, 8,5 \%$ e $5,9 \%$, respectivamente), com o menor valor das mínimas de $12,2^{\circ} \mathrm{C}$ e o maior valor das máximas de $42,2^{\circ} \mathrm{C}$.

Buriol et al. (1993), trabalhando no Rio Grande do Sul, verificaram médias das temperaturas do ar mínimas entre 1,0 a $3,0^{\circ} \mathrm{C}$ superiores às do ambiente externo. As temperaturas do ar encontradas por Fernandes (1996) foram de $32,9^{\circ} \mathrm{C}$ e $28,8^{\circ} \mathrm{C}$ para as 
médias, e $17,3^{\circ} \mathrm{C}$ e $16,7^{\circ} \mathrm{C}$ para as mínimas, respectivamente, no interior e exterior de ambientes protegidos cultivados com crisântemo em Holambra, São Paulo.

Baeten et al. (1985) propuseram um método para cálculo de distribuição de temperatura por meio de vários pontos de amostragem no ambiente protegido $\mathrm{e}$ representação por meio de isotermas calculadas por regressão polinomial bidimensional. Esse método foi aplicado em planos horizontais e em diferentes alturas em todo ambiente protegido. A distribuição de temperatura foi apresentada e discutida permitindo obter uma melhor visão da flutuação de temperatura no ambiente protegido. Entretanto, a análise dos dados obtidos mostrou a ineficiência desse método para extrapolação fora da zona de temperatura medida.

Segundo Al-Jamal (1994) avaliar a adaptação do ambiente protegido através da medição em um ponto não dá a idéia da variação da temperatura e da sua distribuição dentro do ambiente protegido. Dessa forma, vários autores propuseram a análise da distribuição da temperatura do ar no interior do ambiente protegido por meio de vários pontos de amostragem, formando malhas e construindo linhas de distribuição de temperatura iguais no plano, ou seja, isotermas.

Triki et al. (1984) compararam quatro diferentes sistemas de ventilação e sua influência na distribuição de temperatura, mostrada por isotermas, cujas temperaturas foram coletadas a $1,5 \mathrm{~m}$ de altura do solo. Os termopares foram instalados a 2,0m das paredes dos ambientes protegidos e a 4,0m da entrada da mesma, formando uma malha de 3 linhas de 9 termopares espaçados de 7,0m entre des. As dimensões dos ambientes protegidos eram de 64,0 x $8,0 \mathrm{~m}$ com $3,2 \mathrm{~m}$ de pé direito. Foi observado que a distribuição de temperatura foi mais homogênea em ambientes protegidos onde a ventilação lateral foi combinada com ventilação pelo teto. $\mathrm{O}$ uso de dois ventiladores resultou em distribuição de temperatura muito heterogênea, com acúmulo de calor no centro do ambiente protegido. A situação foi ligeiramente amenizada pelo uso de quatro ventiladores, mas houve uma boa melhora quando dois ventiladores foram combinados com um extrator no cume posicionado no centro do ambiente protegido. A comparação da distribuição de temperaturas pelo método octogonal mostrou melhor a influência 
positiva dos sistemas de ventilação na distribuição de temperatura do ar em ambientes protegidos.

Vanhoutte \& Verlodt (1990), estudaram a distribuição de temperatura do ar em cinco ambientes protegidos na Tunísia equipados com diferentes sistemas de ventilação. A distribuição de temperatura do ar em ambiente protegido foi estudada por medidas simultâneas de temperatura usando termopares em diferentes pontos na seção vertical (27 pontos) e horizontal (45 pontos) em 4 níveis de altura $(0,50 \mathrm{~m}, 1,05 \mathrm{~m}, 1,60 \mathrm{~m} \mathrm{e}$ 2,15m). O cálculo de isotermas em diferentes seções do ambiente protegido foi realizado por meio de regressão polinomial bidimensional e interpolação linear. Foi realizado uma análise comparativa dos resultados com os métodos e os desvios entre a imagem calculada e a temperatura medida e concluíram que para a distribuição vertical, a regressão polinomial forneceu resultados com precisão similar bem como a interpolação linear. Entretanto, para a distribuição horizontal, a interpolação linear pareceu ser o método mais correto.

Verheye \& Verlodt (1990), compararam, no sul da Tunísia, três diferentes sistemas de ventilação estática com um ambiente protegido controle com ventilação lateral clássica por meio de aberturas laterais espaçadas na superfície do plástico e encontraram que os melhores resultados foram obtidos no ambiente protegido de maior superfície de ventilação. $\mathrm{O}$ ambiente protegido foi aquele cujo sistema de ventilação consistia em ventilação lateral contínua em combinação com ventilação pela abertura da cobertura plástica na cumieira do ambiente protegido. A influência da ventilação através de aberturas no topo do ambiente protegido foi mostrado através de isotermas por comparação da distribuição vertical de temperatura em ambientes com e sem a abertura, apresentando melhor uniformidade, o ambiente protegido equipado com abertura no teto.

Furlan et al. (1999) avaliaram o efeito de sistemas de resfriamento do ar, usando sistema de nebulização com água à temperatura ambiente através da distribuição da temperatura do ar na horizontal através de isotermas e a distribuição vertical através de gradiente de temperatura do ar em ambiente protegido com cortinas laterais fechadas sobre solo nu em Piracicaba, SP. O ambiente protegido foi instalado no sentido leste- 
oeste, tendo tamanho de 6,4m de largura por 17,5m de comprimento. Foram instalados termopares, formando malhas, com espaçamento horizontal entre eles de 3,0m e nas alturas de $0,5 \mathrm{~m}, 1,0 \mathrm{~m}, 2,0 \mathrm{~m}, 3,0 \mathrm{~m}$ e 4,0m em relação ao solo, constituindo um conjunto de 64 pontos de amostragem. Os dados foram acumulados e armazenados a cada 30 minutos por um sistema de aquisição de dados com dois multiplexadores, em um dia claro de céu aberto (29 de abril de 1999). A nebulização foi aplicada às 12:00h, permanecendo o nebulizador acionado por 30 minutos. A temperatura da água aspergida era de $25,0^{\circ} \mathrm{C}$. Analisou-se a distribuição vertical de temperatura do ar no interior do ambiente protegido antes (12:00h), durante (12:30h) e após o término da nebulização (13:00h). A distribuição horizontal de temperatura foi analisada antes e após a nebulização através de isotermas para os níveis de $0,5 \mathrm{~m}, 2,0 \mathrm{~m}$ e 3,0m de altura em relação ao nível do solo. A homogeneização e a redução da temperatura do ar no ambiente protegido através de nebulização, puderam ser visualizados através de isotermas e do perfil vertical de temperatura do ar. Na altura de 0,5m acima do nível do solo houve menor efeito da nebulização na homogeneização de temperatura. A redução de temperatura do ar provocada pela nebulização da água no ar no ambiente protegido durante 30 minutos foi, em média, de cerca de 12,0\%.

Buriol et al. (1997), determinaram o gradiente térmico vertical no interior de ambientes protegidos com filmes plásticos. Para tanto, foram utilizados dois ambientes protegidos com dimensões de $10,0 \mathrm{~m}$ de largura por $24,0 \mathrm{~m}$ de comprimento, com 3,0m de altura na parte central e 2,0m de pé direito. A temperatura foi medida com sensores instalados nos níveis de $0,2 \mathrm{~m}, 0,6 \mathrm{~m}$ e 2,0 m acima do nível do solo sobre a cultura da alface e do tomate. Calcularam-se os valores médios a cada duas horas, da temperatura do ar nas três alturas medidas. Os resultados mostraram que no interior dos ambientes protegidos, durante o período diurno, ocorreu um aumento da temperatura do ar com a altura, enquanto que no período noturno não se verificou, como seria esperada, a ocorrência de inversão térmica. Este padrão foi observado tanto na cultura de porte baixo (alface), como na cultura de maior porte (tomate).

Com o objetivo de calcular as unidades calóricas (graus dias) no perfil vertical de um ambiente protegido tipo "parral" com 24,0 x 50,0m, com quatro cultivares de 
tomate longa vida e estudar a resposta dos mesmos e sua relação com alguns aspectos de temperatura do ar e do solo, Asborno et al. (1997), conduziram um ensaio em Garina (La Plata). As temperaturas do ar e do solo foram registradas com equipamento programável em seis níveis de observação. Os autores consideraram três subperíodos do ciclo fenológico dos cultivares: transplante - floração; floração - formação do fruto e formação do fruto - maturação, para o estudo da disponibilidade de unidades calóricas dos híbridos em cada nível. As características do perfil térmico das estruturas tipo "parral" determinam grupos de resposta em relação ao rendimento dos cultivares, as quais devem ser consideradas para produção de tomate fora de época convencional.

\subsection{Umidade Relativa do Ar.}

A umidade relativa do ar no interior de um ambiente protegido está inversamente relacionada à temperatura: diminui durante o dia e aumenta durante a noite podendo variar, no período de 24 horas, de 30,0 a 100,0\%. A umidade relativa do ar representa a retenção de vapor de água do ar, cujo déficit de pressão está intimamente vinculado ao processo da evapotranspiração, afetando o equilíbrio hídrico das plantas e provocando um descompasso entre a demanda evaporativa e a capacidade do sistema radicular em absorver água e nutrientes. Nas estações e períodos mais quentes do dia, as plantas, especialmente aquelas com baixo índice de área foliar, diminuem a transpiração, sendo assim impedidas de aproveitar a energia disponível (Lourenzo Míngues, 1998).

A umidade relativa do ar influencia a transpiração, o crescimento, a fecundação das flores e a ocorrência de doenças (Cermeño, 1994). Altos valores de umidade relativa do ar reduzem a taxa de evapotranspiração da cultura. Quando associados a altas temperaturas do ar geram também condições muito favoráveis à ocorrência de doenças. Já valores muito baixos de umidade relativa também podem provocar altas taxas de evapotranspiração, que podem reduzir a taxa fotossintética e, conseqüentemente, a produção da cultura. De acordo com Baêta \& Souza (1997), em ambientes protegidos, as plantas cresceriam melhor quando expostas a alta umidade (70,0 a 80,0\%) porque, 
assim, o estresse evaporativo seria reduzido. A Tabela 1 apresenta a umidade relativa ótima para algumas culturas em ambiente protegido segundo Cermeño (1994).

Tabela 1. Umidade relativa ótima para as principais espécies cultivadas em ambiente protegido.

\begin{tabular}{lc}
\hline Cultura & Umidade Relativa (\%) \\
\hline Tomate & $50-60$ \\
Pimentão & $50-60$ \\
Berinjela & $50-65$ \\
Pepino & $70-90$ \\
Abóbora & $65-80$ \\
Melão & $60-70$ \\
Melancia & $65-75$ \\
Feijão-verde & $60-75$ \\
Morango & $70-80$ \\
Ervilha & $65-75$ \\
Alface & $60-80$ \\
Acelga & $60-70$ \\
Aipo & $65-80$ \\
\hline
\end{tabular}

Fonte: Cermeño (1994).

Outro efeito da umidade do ar no interior dos ambientes protegidos é sua condensação na face interna do filme plástico de cobertura e conseqüente redução na transmitância da radiação solar, afetando negativamente a disponibilidade de energia para as plantas.

Pezzopane et al. (1995) trabalhando em ambiente protegido, coberto com filme de polietileno, com manejo de cortinas laterais, observaram pressões de vapor atuais maiores no ambiente protegido do que a céu aberto. Os maiores valores ocorreram no período da manhã. A não renovação do ar associada à incidência dos primeiros raios solares, aumentando a evapotranspiração, acentuou a elevação da pressão atual de vapor. 
Com a abertura das cortinas de manhã, esses valores decaíram rapidamente, subindo novamente com o fechamento das laterais no período da tarde. Em geral, o valor da umidade relativa máxima é maior dentro do ambiente protegido do que no ambiente externo. Farias et al. (1993) encontraram médias das máximas no interior do ambiente protegido $(95,6$ a 99,2\%) superiores às verificadas a céu aberto $(91,4$ a 99,0\%), na maior parte do experimento. Maiores umidades relativas máximas também foram encontradas por Pezzopane et al. (1995) no ambiente protegido. Esses valores ocorrem, em geral, à noite ou nas primeiras horas da manhã. A retenção de vapor de água pelo filme plástico, associado à queda de temperatura do ar durante a noite, que reduz a tensão de saturação de vapor de água, contribui para os maiores valores de umidade relativa do ar.

Folegatti et al. (1997) utilizando ambiente protegido tipo capela coberta com PEBD de $150 \mu$ e localizada no sentido noroeste-sudeste, observaram para o período de primavera, nos dias com baixa umidade, maior valor de umidade relativa do ar no ambiente protegido em comparação com o meio externo, ao contrário do que aconteceu em dias com muita umidade. Estes autores verificaram ainda uma menor amplitude de umidade relativa do ar no interior do ambiente protegido devido ao manejo das cortinas e à baixa renovação do ar interior.

Farias et al. (1993) verificaram médias de umidade relativa mínima menores o interior da casa de vegetação, o que foi justificado pelas maiores temperaturas do ar diurnas encontradas neste ambiente, o que permite maior valor de pressão de saturação de vapor de água. Com o ambiente protegido aberto neste período, a pressão atual de vapor não permanece muito acima da verificada externamente, propiciando menor valor de umidade relativa no interior do ambiente protegido, devido somente à maior pressão de saturação.

Esses autores mostraram, ainda, que no início do desenvolvimento, os valores de umidade relativa do ar interna foram inferiores aos externos, ocorrendo em seguida um período de equilíbrio e, posteriormente, valores mais altos no interior. Isso é devido ao aumento da transpiração com o desenvolvimento da cultura, aumentando a pressão atual de vapor e, consequentemente, aumentando a umidade relativa do ar acentuada pela pequena renovação da massa de ar interna. 
De acordo com Martins et al. (1996), uma solução para superar os problemas relacionados com a umidade relativa do ar no interior dos ambientes protegidos, especialmente o excesso de vapor de água, seria um adequado manejo. Este compreenderia, no caso de ambientes protegidos não climatizados, aberturas (em 30,0\% da superfície total) que proporcionem uma ventilação natural eficiente e, nos ambientes protegidos climatizados, o uso de ventiladores e desumidificadores. Os mecanismos de ventilação, especialmente os naturais, não dispensam o manejo adequado de abertura e fechamento dos ambientes protegidos, pois dependerão das condições climáticas e meteorológicas locais. Os filmes plásticos, no que pese sua eficiência na transmissão da radiação solar, devem ser capazes de reduzir a condensação e evitar o gotejo sobre as plantas (efeito que em parte pode ser conseguido com um desenho de cumieira que favoreça o escorrimento da água condensada para as laterais do ambiente protegido). Cabe salientar, ainda, a necessidade de ter plantas bem vigorosas e com bom equilíbrio entre parte aérea e raiz para superar os efeitos fisiológicos causados pelos elevados valores de déficit de pressão de vapor, isto é, a baixa umidade relativa do ar e riscos de incidência de patógenos nos momentos de baixo déficit de pressão de vapor, ou seja, de alta umidade relativa.

\subsection{Performance do resfriamento evaporativo.}

Com o aumento da temperatura da água o calor latente de vaporização decresce. Consequentemente, a água quente evapora mais rápido que a fria. Uma vez que adicionando-se energia à água esse processo é facilitado, é concebível que a eficiência de um sistema de resfriamento evaporativo poderia aumentar se a água fornecida for aquecida. Entretanto, esse argumento não considera o calor sensível adicionado à água, o qual é no mínimo parcialmente adicionado na ventilação do ar (Simmons \& Lott, 1996).

A seguinte relação, apresentada por ASHRAE (1983) e modificada por Bottcher et al. (1991) pode ser utilizada para determinar a eficiência do processo de resfriamento de abrigos para frango de corte: 
$\mathrm{E}_{\mathrm{ff}}=\frac{\mathrm{T}_{\mathrm{b}}-\mathrm{T}_{\mathrm{i}}}{\mathrm{T}_{\mathrm{b}}-\mathrm{T}_{\mathrm{wwb}}} * 100 \%$

em que:

$\mathrm{E}_{\mathrm{ff}}=$ eficiência do resfriamento evaporativo (\%);

$\mathrm{T}_{\mathrm{b}}=$ temperatura do bulbo seco interno após a adição de calor sensível $\left({ }^{\circ} \mathrm{C}(\mathrm{F})\right)$;

$\mathrm{T}_{\mathrm{i}}=$ temperatura do bulbo seco interna final $\left({ }^{\circ} \mathrm{C}(\mathrm{F})\right)$;

$\mathrm{T}_{\mathrm{iwb}}=$ temperatura do bulbo úmido interna final $\left({ }^{\circ} \mathrm{C}(\mathrm{F})\right)$;

Essa equação é uma expressão válida para descrever a eficiência do sistema de nebulização. Entretanto, seria virtualmente impossível medir a temperatura do bulbo seco interna, $\mathrm{T}_{\mathrm{b}}$, após a adição de calor sensível. Ela poderia, possivelmente, ser estimada ou medida antes da nebulização e assumida ser similar durante a nebulização, mas medidas cuidadosas durante a nebulização são muito difíceis, devido em parte ao molhamento do sensor de temperatura e incompleta mistura do ar.

Simmons \& Lott (1996) estudaram um protótipo de um sistema de resfriamento evaporativo "pad fan", usado para determinar o efeito da temperatura da água na performance do resfriamento evaporativo. O sistema teste foi construído e operado dentro de um aviário de paredes sólidas e bem isolado. As temperaturas do ar de entrada foram $32,0,35,0$ e $38,0^{\circ} \mathrm{C}$. A temperatura da água fornecida variou de 10,0 a $50,0^{\circ} \mathrm{C}$ com incrementos de $5,5^{\circ} \mathrm{C}$. Para cada temperatura do ar inicial de entrada no teste, com cada incremento de temperatura da água, a performance do sistema de resfriamento evaporativo piorava, pois a quantidade de água que evapora aumentava com o aumento da temperatura da água fornecida e a eficiência do resfriamento evaporativo decrescia com o acréscimo da temperatura da água fornecida. Se o resfriamento evaporativo for por nebulização (com água aquecida), o calor adicionado da água poderia ir a duas direções. Se toda água aspergida no ar for evaporada, o calor sensível extra, poderia ser absorvido pela atmosfera da casa. Entretanto, se a adição de água excedeu a taxa de evaporação (a situação freqüentemente ocorre de manhã e à tarde no dia ou com pressão de água moderada), a porção de calor sensível adicionada poderia favorecer a 
condensação de água sobre as aves, promovendo um molhamento ou umidecimento das aves, o que poderia causar doenças.

2.6. Considerações termodinâmicas sobre a ação do nebulizador.

O diagrama psicrométrico nos permite avaliar a ação nebulizadora do "fogger". Supondo que num determinado momento a temperatura e a umidade relativa do ar no interior de um ambiente protegido esteja a $30,0^{\circ} \mathrm{C}$ e $40,0 \%$ respectivamente. Injetando uma quantidade de neblina de tal forma que a umidade relativa do ar passe no final do processo para 70\%, embora a entalpia seja constante $(18 \mathrm{kcal} / \mathrm{kg}$ de ar), nesta nova condição a emperatura do ar cairá em função do aumento do conteúdo de vapor (de 10 para $13 \mathrm{~g}$ de vapor $/ \mathrm{kg}$ de ar) para $24,0^{\circ} \mathrm{C}$, ocasionando uma queda na temperatura de $6,0^{\circ} \mathrm{C}\left(30,0-24,0^{\circ} \mathrm{C}\right)$.

2.7. Combinação dos sistemas de resfriamento.

$\mathrm{Na}$ prática, não é muito comum usar um único método de resfriamento. Normalmente, a combinação de muitos métodos é utilizada. Para se tornar familiar com o efeito combinado de vários métodos, experimentos tem sido realizados ou modelos de simulação tem sido desenvolvidos (Landsberg et al., 1979).

Um modelo de simulação comparou a diferença de temperatura do ar com a taxa de ventilação em quatro ambientes protegidos em dois climas (Montero \& Antón, 1994):
A) Resfriamento com sistema de nebulização;
B) Sistema de nebulização e malha branca de sombreamento com transmissão de $40 \%$;
C) Malha branca sem nebulização;
D) Controle (sem nebulização e malha).

O modelo de simulação comparou condições de verão ao meio dia na costa próxima a Barcelona (Radiação global de $900 \mathrm{~W} / \mathrm{m}^{2} ; 25,3^{\circ} \mathrm{C} ; 71,0 \%$ de umidade relativa) e clima mais seco e continental (Radiação global de $900 \mathrm{~W} / \mathrm{m}^{2} ; 28,4^{\circ} \mathrm{C} ; 38,0 \%$ de umidade relativa). 
Dos resultados obtidos, pôde-se concluir que:

1) Em todos os ambientes protegidos nos dois climas, pôde-se ver que a diferença de temperatura decresce com o incremento na taxa de ventilação, mas após a taxa de renovação de 20 volumes por hora a diferença de temperatura decresce vagarosamente.

2) $\mathrm{O}$ efeito do sombreamento é mais positivo em ambientes protegidos mal ventilados. Por exemplo, para renovação de ar de 10 volumes por hora, o sombreamento permitiu temperatura mais baixa que o controle entre 3,0 e $4,0^{\circ} \mathrm{C}$, enquanto que para renovação de 60 volumes por hora, o decréscimo foi de apenas $1,0^{\circ} \mathrm{C}$.

3) A eficiência do sistema de nebulização é claramente maior em um clima continental com $38 \%$ de umidade relativa, quando comparada com um clima litorâneo com $71 \%$ de umidade relativa. Então, para um índice de ventilação de 30 volumes por hora, a temperatura do ambiente protegido é praticamente a mesma da temperatura externa no litoral, e entre 5,0 e $7,0^{\circ} \mathrm{C}$ abaixo da temperatura externa em um clima seco.

4) Quando se usa equipamento umidificador, o ambiente protegido deve ser ventilado. A capacidade desse equipamento deve ser suficiente para fornecer água necessária para manter a umidade relativa muito alta $(85,0$ a $90,0 \%)$ no ambiente protegido, com taxa de ventilação de 20 a 30 volumes por hora.

De acordo com Montero \& Antón (1994), quando o ambiente protegido não tem cultura, o clima é consideravelmente diferente.

Simulando situações iguais às anteriores, mas tendo-se dentro do ambiente protegido uma cultura, e com uma razão de Bowen $=1 / 20$ (Landsberg et al., 1979), chegou-se as diferentes conclusões:

1) Em ambientes protegidos sem nebulização, os requerimentos com ventilação são maiores quando comparada àquele ambiente protegido com cultura. Em oposição à situação anterior, a taxa de renovação de ar de 30 volumes por hora é claramente insuficiente.

2) Em ambientes protegidos sem nebulização, o sombreamento reduz a temperatura do ar. Entretanto, quando equipamentos umidificadores são usados, o sombreamento perde a eficiência. Poderia parecer que quando outra fonte de resfriamento existe (transpiração da cultura, sistema de nebulização ou alta taxa de ventilação), o sombreamento tem 
pequeno efeito na temperatura do ar em ambiente protegido, enquanto para estrutura de má ventilação sem cultura ou equipamento umidificador, a eficiência do sombreamento é extremamente alta.

3) Em ambientes protegidos com sistemas de nebulização, as curvas de temperatura comparadas à ventilação são muito similares, independente do ambiente protegido ter cultura ou não. Ambos, transpiração e sistema de nebulização são meios de evaporação de água e uma pode complementar ou substituir o efeito do resfriamento da outra.

4) $\mathrm{Na}$ primeira fase do desenvolvimento da cultura, somente é possível conseguir um clima favorável no ambiente protegido em meses quentes se a taxa de ventilação for igual ou maior que renovação de 60 volumes por hora, ou se a umidade é adicionada ao ar do ambiente protegido com equipamento apropriado.

Com a combinação inteligente de diferentes sistemas de resfriamento, um clima muito adequado pode ser conseguido durante meses mais quentes, tanto em áreas litorâneas como continentais em ambientes protegidos com cultura ou sem. Para alcançar esse clima favorável, os ambientes protegidos de estruturas simples têm um problema sério que é a falta de ventilação. Janelas que podem ser adaptadas ao teto devem ser projetadas para esses ambientes protegidos simples, caso produtos de qualidade venham a ser cultivados nelas durante os meses mais quentes.

De acordo com Andriolo (1999), quando um raio luminoso atinge a superfície do material de cobertura de um ambiente protegido, a sua energia se divide em três frações: uma parte é refletida, outra é absorvida e uma terceira é transmitida. A parte refletida é perdida para a atmosfera e a parte absorvida irá aquecer o material de cobertura, o qual, posteriormente, emitirá a energia absorvida nas duas direções. Por isso, considera-se que somente a metade, aproximadamente, da energia solar absorvida pelo material será recuperada pela cultura. A parte que é transmitida passa diretamente para o interior do ambiente protegido onde está a cultura. Nesse ambiente, uma competição pela energia luminosa se estabelece entre as plantas e todos materiais existentes, como as estruturas de sustentação e condução das plantas e também o solo. Este último é um grande absorvedor de energia luminosa, principalmente pelo calor latente de vaporização da água que esta contida em seu interior. 
Em geral, altas temperaturas do ar no interior do ambiente protegido, diminui o rendimento e a qualidade dos vegetais, chegando a produzir, em alguns casos extremos, a morte de plantas (Berninger ${ }^{2}$, citado por Francescangeli et al.,1994).

De acordo com Andriolo (1999), o manejo das temperaturas excessivamente elevadas pode ser feito pela ventilação ou pela nebulização, sendo a ventilação mais fácil de ser utilizada, aquela do tipo estática, que depende basicamente das diferenças de pressão entre o ar localizado no interior e no exterior do ambiente protegido.

O emprego da nebulização para diminuir a temperatura do ar depende do déficit de saturação do ar. Quando um déficit de saturação existe, a aspersão de finas gotículas de água no estado líquido permite extrair uma parte da energia do ar mediante a passagem dessas gotículas ao estado de vapor, reduzindo a temperatura. Essa técnica será tão mais eficiente quanto maior for o déficit de saturação. Por exemplo: o ar está com $40,0 \%$ de umidade relativa e $35,0^{\circ} \mathrm{C}$ de temperatura. Quando a umidade relativa passa a $100 \%$ pela nebulização, a temperatura do ar diminui para aproximadamente $21,0^{\circ} \mathrm{C}$. Porém, quando a umidade do ar já está em valores elevados, a nebulização proporciona resultados pouco satisfatórios. Por essa razão, é mais conveniente empregar a ventilação e a nebulização simultaneamente. Quando realizada corretamente na forma de finas gotículas, a nebulização pode ser uma alternativa eficiente para o manejo de temperaturas excessivamente elevadas do ar. Porém, quando realizada de maneira incorreta pode provocar o molhamento das plantas, aumentando o risco de ocorrência de moléstias (Andriolo, 1999).

Quando a temperatura e o déficit de saturação do ar são mantidos sob valores moderados através da nebulização, a cultura pode suportar altos níveis de radiação sem que o fechamento dos estômatos ocorra (Andriolo, 1999).

A temperatura do ar no interior de um ambiente protegido, durante as épocas quentes, pode também ser manejada pela redução da intensidade de energia solar que penetra no seu interior. Essa redução se faz pela diminuição da transmissividade do

\footnotetext{
${ }^{2}$ BERNINGER, E. Cultures florales de serre en zone mediterraneenne francaise. Edit. INRA-PHM Revue
} Horticole, 1989. $206 \mathrm{p}$. 
material de cobertura, através de uma pintura de cor branca em uma das faces. Porém, esta técnica tem o inconveniente de reduzir simultaneamente a temperatura e a radiação disponível para a fotossíntese das plantas (Andriolo, 1999).

2.8. Radiação solar no interior dos ambientes protegidos.

A densidade de fluxo de radiação solar no interior do ambiente protegido é menor que a verificada externamente, devido à reflexão e à absorção do material de cobertura plástica (Martin et al., 1982).

O polietileno de baixa densidade (PEBD) é o material plástico mais empregado atualmente na agricultura mundial e é um material que apresenta boa transparência à radiação solar, deixando passar em média 70,0 a 80,0\% da radiação solar, podendo este percentual atingir no máximo, 95,0\% (Martin \& Robledo, 1981).

Robledo de Pedro (1987), comparando vários tipos de plásticos, verificou uma perda média variando de 10,0 a 17,0\% na transmissividade, enquanto que Farias et al. (1993), utilizando polietileno de baixa densidade (PEBD), verificou uma redução de 10,0 a 35,0\% na transmissividade no intervalo de 11 à 13 horas e de 17,0\%, em média, ao longo do dia. Montero et al. (1985) e Mills et al. (1990), também encontraram resultados que muito se aproximam destas observações.

Medindo a radiação solar global no interior de um ambiente protegido coberto com PEBD, Al-Riahi et al. (1989), observaram um aumento na transmissividade devido a uma menor condensação na cobertura plástica e principalmente devido ao aumento do azimute do sol, caracterizando assim uma variação temporal da transmissividade.

De maneira geral, pode-se dizer que a quantidade de energia solar não transmitida é devido ao tipo de cobertura e ao ângulo de incidência dos raios solares, o que é condicionado pela orientação do ambiente protegido, pela inclinação do telhado e posição do sol (Robledo de Pedro \& Vicente, 1988; Hanan et al., 1978)

Contudo, embora exista uma redução da radiação solar global no interior do ambiente protegido, Farias et al. (1993), encontrou um maior valor da razão entre radiação difusa e total ( $\mathrm{Rd} / \mathrm{Rs})$ dentro do ambiente protegido, sendo este fator muito 
importante, pois a radiação difusa é multidirecional podendo ser melhor aproveitada pelas plantas. Esta relação de $\mathrm{Rd} / \mathrm{Rs}$, pode variar bastante entre os diferentes tipos de plásticos, variando de 15,0\% para polietileno normal (sem aditivo), até 65,0\% em alguns materiais (Robledo de Pedro, 1987).

Pezzopane (1994), utilizando ambiente protegido coberto com PEBD na produção de mudas de seringueira, verificou que no interior do ambiente protegido a radiação solar global foi reduzida e a radiação líquida noturna foi menos negativa. Em algumas horas do dia, ocorreu um aumento na pressão atual de vapor e umidade relativa resultando em redução do déficit de pressão de vapor. Também verificou elevação da temperatura do solo e das folhas de seringueira no interior do ambiente protegido.

\subsection{Efeito estufa}

Extremamente importante para as plantas cultivadas dentro de ambientes protegidos, este aumento de temperatura (ou a sua manutenção no período noturno) é causado pelo bloqueio (maior ou menor) que os materiais plásticos fazem às radiações de longo comprimento de onda, entre $5.000-35.000 \mathrm{~nm}$, que partem do solo e das plantas em direção à atmosfera (Siqueira, 1994).

Esta propriedade de reter os comprimentos de onda longos é denominada transmissão térmica que, quanto menor, maior efeito estufa ocasionará.

A pesquisa agronômica no campo da plasticultura procura obter películas plásticas de ambientes protegidos que apresentem níveis cada vez mais baixos de transmissão térmica, fator extremamente importante para as plantas, principalmente no período noturno, onde um maior equilíbrio de temperatura no interior dos ambientes protegidos pode resultar em aumento da produtividade.

As radiações noturnas emitidas pelo solo e pelas plantas situam-se entre 2.500 $70.000 \mathrm{~nm}$, com uma concentração máxima na faixa de $10.000 \mathrm{~nm}$.

As informações sobre as características dos filmes plásticos utilizados na agricultura são de responsabilidade dos fabricantes. Estes devem informar sobre seus filmes 
plásticos, de modo que o técnico, o agrônomo e o produtor rural possam eleger os materiais e marcas pela qualidade da luz que os filmes transmitam.

O filme plástico não deve ser comprado só pelo preço e pela vida útil, mas também pela qualidade na transmissão da radiação solar.

Se o filme plástico utilizado não for de boa qualidade (apesar de transparente) acarretará, após alguns meses de uso, bloqueios de comprimentos de radiação luminosa que poderão interferir na produção. $\mathrm{O}$ que foi ganho com o baixo preço na compra do plástico será perdido com a necessidade de aumento da adubação, irrigação e pulverização, na tentativa de regularizar a produção. 


\section{MATERIAL E MÉTODOS}

3.1. Caracterização do local e período de experimentação.

O presente trabalho foi realizado no período de 01/10/99 a 19/05/00, em ambientes protegidos, sobre solo nu, na área experimental do Departamento de Engenharia Rural, da Escola Superior de Agricultura "Luiz de Queiroz", situada no município de Piracicaba, SP, cujas coordenadas geográficas são: Latitude $22^{\circ} 42^{\prime} \mathrm{S}$, Longitude $47^{\circ} 38^{\prime} \mathrm{W}$ e altitude de 570 metros.

Segundo a classificação climática de Köppen, Piracicaba possui clima Cwa, ou seja, subtropical úmido, com estiagem no inverno. Os valores médios mensais normal obtidos através dos dados coletados no posto agrometeorólogico do Departamento de Ciências Exatas em 83 anos (de 1917 a 2000), de precipitação (mm), umidade relativa $(\%)$, velocidade do vento média $(\mathrm{km} / \mathrm{h})$, temperatura máxima do ar $\left({ }^{\circ} \mathrm{C}\right)$, temperatura mínima do ar $\left({ }^{\circ} \mathrm{C}\right)$ e temperatura média do $\operatorname{ar}\left({ }^{\circ} \mathrm{C}\right)$, estão na Tabela 2.

O solo do local do experimento é classificado como Terra Roxa Estruturada (Alfisol), série Luiz de Queiroz, plana.

Foram instalados dois ambientes protegidos similares para a coleta e comparação dos dados, no sentido leste-oeste, tendo as seguintes características: dimensões de 6,4 m de largura por 17,5 m de comprimento; estrutura pré-fabricada de ferro galvanizado; pé direito de 3,0 m; altura total de 4,2m; área total de 112,0 m²; espessura do plástico de 150 micra; filmes plásticos em PVC SANSUY com tratamento contra raios ultravioleta; janelas zenitais de abertura longitudinal de 1,5m de largura; comprimento de 17,5m fechada com tela de malha 30,0\%; janelas laterais fechadas com sombrite a 60,0\% e 
plástico removível. A Figura 1 apresenta a área experimental em cultivo protegido do Departamento de Engenharia Rural com os ambientes protegidos utilizados.

Tabela 2. Valores médios mensais normal de precipitação $(\mathrm{mm})$, umidade relativa $(\%)$, velocidade do vento média $(\mathrm{km} / \mathrm{h})$, temperatura máxima do ar $\left({ }^{\circ} \mathrm{C}\right)$, temperatura mínima do ar $\left({ }^{\circ} \mathrm{C}\right)$ e temperatura média do ar $\left({ }^{\circ} \mathrm{C}\right)$ para Piracicaba, SP.

\begin{tabular}{lcccccc}
\hline \multicolumn{1}{c}{ Mês } & $\begin{array}{c}\text { Precipitação } \\
(\mathrm{mm})\end{array}$ & $\begin{array}{c}\text { Umidade } \\
\text { Relativa } \\
(\%)\end{array}$ & $\begin{array}{c}\text { Velocidade } \\
\text { Do vento } \\
(\mathrm{km} / \mathrm{h})\end{array}$ & $\begin{array}{c}\text { Temperatura } \\
\text { Máxima } \\
\left({ }^{\circ} \mathrm{C}\right)\end{array}$ & $\begin{array}{c}\text { Temperatura } \\
\text { Mínima } \\
\left({ }^{\circ} \mathrm{C}\right)\end{array}$ & $\begin{array}{c}\text { Temperatura } \\
\text { Média } \\
\left({ }^{\circ} \mathrm{C}\right)\end{array}$ \\
\hline Janeiro & 224,4 & 76,0 & 7,8 & 30,0 & 18,9 & 24,4 \\
Fevereiro & 185,2 & 76,0 & 7,4 & 30,2 & 19,0 & 24,6 \\
Março & 143,0 & 76,0 & 7,2 & 30,0 & 18,2 & 24,1 \\
Abril & 64,0 & 74,0 & 7,1 & 28,3 & 15,3 & 21,8 \\
Maio & 52,1 & 75,0 & 6,4 & 26,1 & 12,1 & 19,1 \\
Junho & 44,0 & 75,0 & 6,8 & 24,9 & 10,3 & 17,6 \\
Julho & 27,2 & 70,0 & 7,5 & 25,3 & 9,5 & 17,4 \\
Agosto & 29,7 & 64,0 & 8,2 & 27,3 & 11,0 & 19,1 \\
Setembro & 63,9 & 65,0 & 9,3 & 28,1 & 13,4 & 20,7 \\
Outubro & 110,3 & 70,0 & 9,8 & 28,9 & 15,6 & 22,3 \\
Novembro & 130,4 & 70,0 & 9,7 & 29,6 & 16,7 & 23,1 \\
Dezembro & 201,0 & 74,0 & 8,9 & 29,6 & 18,2 & 23,9 \\
\hline Média & $\mathbf{1 0 6 , 3}$ & $\mathbf{7 2 , 1}$ & $\mathbf{8 , 0}$ & $\mathbf{2 8 , 2}$ & $\mathbf{1 4 , 9}$ & $\mathbf{2 1 , 5}$ \\
\hline Total & $\mathbf{1 2 7 5 , 2}$ & & & & & \\
\hline
\end{tabular}




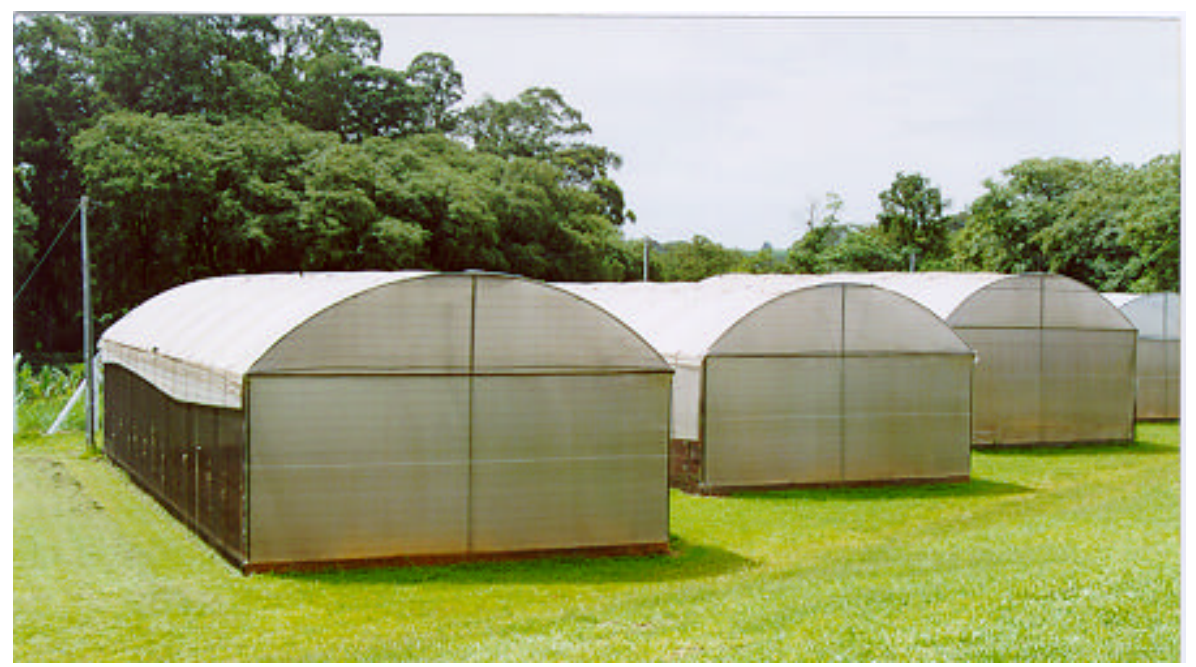

Figura 1. Ambientes protegidos utilizados no experimento, em Piracicaba, SP.

3.2. Variáveis meteorológicas internas e externas.

As medidas de temperatura e umidade relativa do ar e radiação líquida e global e fluxo de calor no solo foram registrados em sistemas de aquisição de dados CR10, CR7 (Campbell Scientific), armazenados em intervalos de 15 minutos, ligados ininterruptamente.

\subsubsection{Temperatura do ar no ambiente protegido.}

Com o propósito de caracterizar e avaliar um sistema de resfriamento por nebulização em ambientes protegidos, foi realizada uma amostragem sistemática pelo uso de 78 termopares regularmente distribuídos nas três direções do espaço (comprimento, largura e altura). Os termopares, constituídos de pares termoelétricos de cobre-constantã foram instalados em micro-abrigos de PVC branco nos níveis correspondentes às alturas de 0,5m, 1,0m, 2,0m, 3,0m e 4,0m em relação ao nível do solo e com espaçamento horizontal entre eles de 3,0m. Esses termopares (seco e úmido) foram calibrados previamente em laboratório. 
$\mathrm{Na}$ Figura 2 estão representadas as dimensões transversais do ambiente protegido.

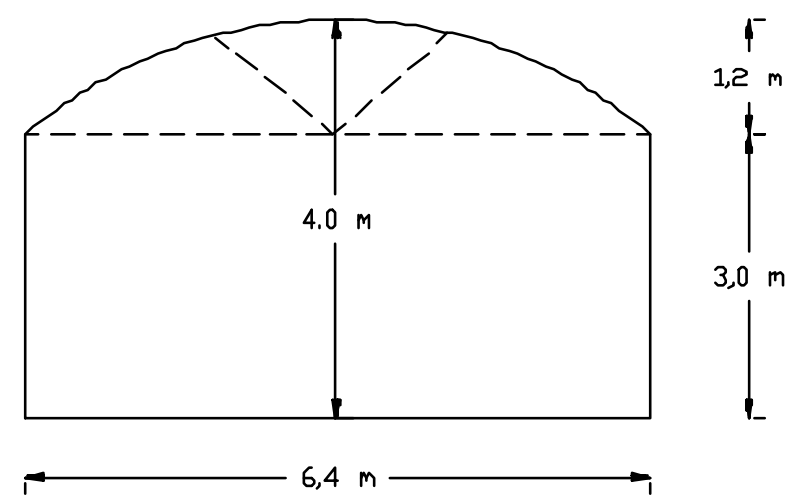

Figura 2. Dimensões do ambiente protegido no sentido transversal.

A Figura 3 mostra a representação esquemática da localização das 18 estacas de sustentação dos termopares na direção horizontal e a Figura 4, a dos termopares na direção vertical.

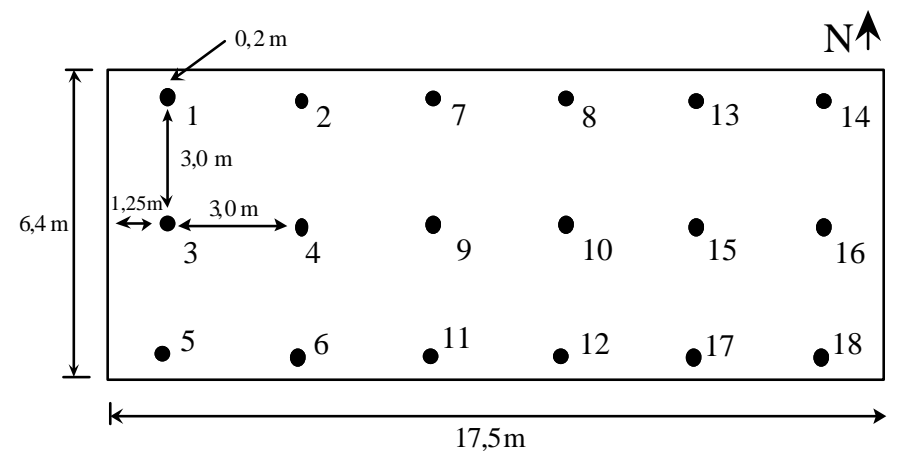

Figura 3. Localização dos termopares na direção horizontal dentro do ambiente protegido. 


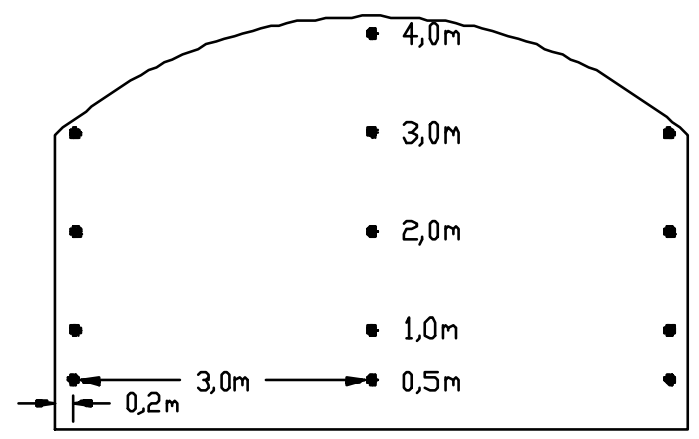

Figura 4. Localização dos termopares na direção vertical dentro do ambiente protegido.

A distribuição dos termopares nas três direções do espaço (comprimento, largura e altura) foi determinada a partir da disponibilidade de equipamento para a coleta de dados, bem como das dimensões do ambiente protegido. Apesar de haver o mesmo esquema de instalação nos dois ambientes protegidos, no ambiente 1, por capacidade do equipamento, alguns termopares não puderam ser ligados, ficando o ambiente com menor número de posições de coleta de dados.

Dois sistemas de aquisição de dados, sendo um CR7 e um CR10 com dois multiplexadores, foram utilizados com o propósito de armazenar o sinal dos termopares instalados nos ambientes protegidos, com leituras a cada segundo e médias a cada 15 minutos. No ambiente protegido 1, foram instalados 59 termopares para medir a temperatura do ar e 5 termopares de bulbo úmido para caracterizar o perfil vertical de umidade relativa do ar. No ambiente protegido 2, foram instalados 78 termopares para medir a temperatura do ar e 5 termopares de bulbo úmido para a caracterização do perfil vertical de umidade relativa do ar.

Os pontos de amostragem formaram uma malha que permitiram traçar as isotermas, ferramenta esta, utilizada para a análise dos ambientes.

\subsubsection{Umidade relativa do ar no ambiente protegido.}

Em cada um dos ambientes protegidos foram instalados termopares de bulbo seco e úmido para obtenção de umidade relativa. A posição destes termopares corresponde a 
posição de número 10, descrita e vista anteriormente na Figura 3. Os psicrômetros foram constituídos de pares termoelétricos de cobre-constantã sendo um seco e um umedecido por uma gaze embebida em água destilada conforme procedimento utilizado por Cunha et al. (1996). Os termopares foram instalados as mesmas alturas correspondentes aos termopares de bulbo seco, ou seja, a 0,5m, 1,0m, 2,0m, 3,0 e 4,0m. Na Figura 5 observam-se os termopares de bulbo seco e de bulbo úmido.

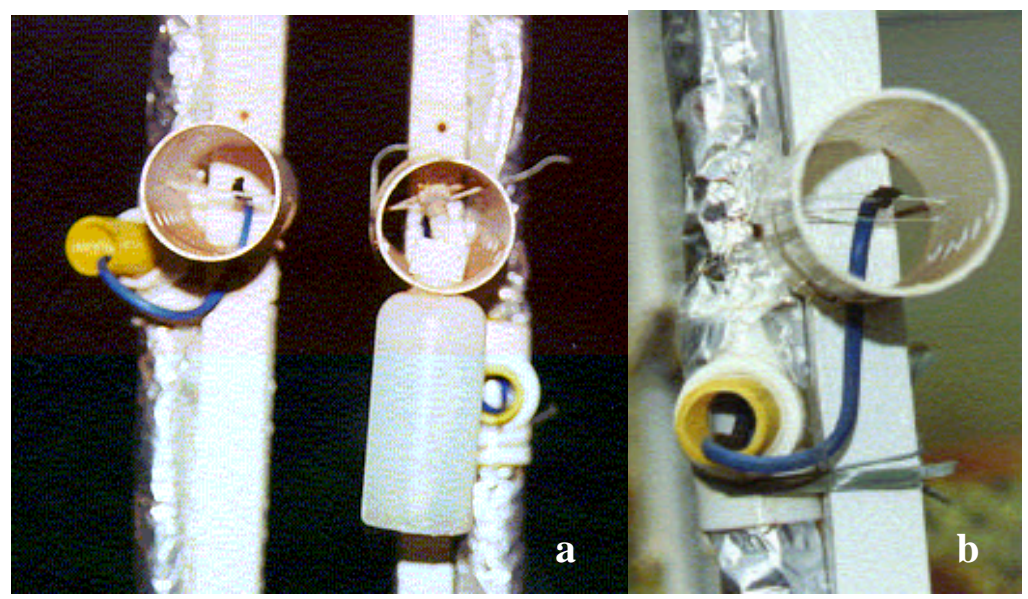

Figura 5. Pares termo-elétricos de cobre-constantã de bulbo seco e de bulbo úmido (a) e de bulbo seco (b), instalados nos ambientes protegidos em micro-abrigos de PVC branco.

\subsubsection{Radiação solar e fluxo de calor no solo no ambiente protegido.}

No ambiente protegido 2 (E2) foram conectados ao sistema de aquisição de dados, conforme recomendação utilizada em postos meteorológicos padrão, os seguintes sensores:

- radiação solar global a 2,0 m de altura (modelo: LI200X Pyranometer - Li-cor Inc.).

- saldo de radiação a 1,0 m de altura em relação ao nível do solo (modelo: Q7.1 Net

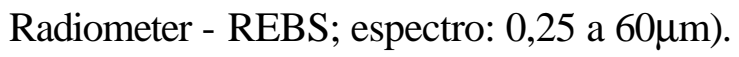

- fluxo de calor no solo a 2,0 cm de profundidade (modelo: HFT-3 Soil Heat Flux Plate)

Os sensores de radiação solar global e o sensor de saldo de radiação foram instalados no centro do ambiente protegido entre as estacas 4 e 9 e o sensor de fluxo de 
calor no solo foi instalado entre as estacas 9 e 10 (sobre um lisímetro de pesagem instalado nesse local). O intervalo de armazenagem de dados foi de 15 minutos.

\subsubsection{Variáveis meteorológicas externas.}

As informações meteorológicas foram obtidas na estação meteorológica automática instalada no posto agrometeorológico do Departamento de Ciência Exatas (Setor de Física e Agrometeorologia) que possui os sensores de:

- temperatura do ar e umidade relativa do ar a 2,0m de altura (modelo: HMP35C Temperature/RH Probe - Campbell; acurácia: temperatura $= \pm 0,1^{\circ} \mathrm{C}$; umidade relativa $= \pm 3,0 \%$ ).

- radiação solar global a 2,0m de altura (modelo: LI200X Pyranometer - Li-cor Inc.).

- velocidade do vento a 2,0m de altura (modelo: 014A Wind Speed Sensor - Met One Instruments; com medidas a partir de $0,45 \mathrm{~m} / \mathrm{s})$.

- direção do vento a 2,0m de altura (modelo: 024A Wind Direction Sensor - Met One Instruments; acurácia $= \pm 5^{\circ}$ ).

- precipitação a 1,5m de altura (modelo: TE525 Tipping Bucket Rain Gage - Weather Bureau; precisão $=0,1 \mathrm{~mm}$ ).

- saldo de radiação a 1,0m da cobertura vegetal (modelo: Q7.1 Net Radiometer - REBS; espectro: 0,25 a $60 \mu \mathrm{m})$.

Todos os sensores estavam conectados a um sistema de aquisição de dados (modelo: CR10, Campbell Scientific) que armazenava informações médias a cada 15 minutos.

\subsection{Sistema de nebulização.}

O sistema de nebulização constituiu de duas linhas com 70 bocais $(0,20 \mathrm{~m}$ de espaçamento entre cada bocal), instalados a uma altura de $3,0 \mathrm{~m}$. O modelo utilizado foi o DAN FOGGER 7800 (Dan Sprinklers) e a densidade de 1,6 $\mathrm{m}^{2} /$ bico nebulizador. No sistema foi aplicada uma pressão de 20 m.c.a. 
$\mathrm{O}$ acionamento do sistema de nebulização foi realizado manualmente em horários pré determinados. A nebulização foi intermitente, permanecendo o nebulizador acionado por 15 minutos e desligado por 15 minutos sucessivamente.

3.4. Distribuição vertical e horizontal de temperatura do ar (isotermas) em ambientes protegidos.

Para a determinação do gradiente térmico vertical no interior do ambiente protegido, utilizou-se a média de quatro pontos de amostragem para cada uma das cinco alturas acima do nível do solo $(0,5 ; 1,0 ; 2,0 ; 3,0$ e 4,0m). Os pontos amostrados corresponderam aos termopares instalados nas estacas 4, 9, 10 e 15, localizados na parte central do ambiente protegido (Figura 3).

Dentro do ambiente protegido foram coletados dados de outubro de 1999 a maio de 2000, em 78 pontos de amostragem regularmente distribuídos nas três direções do espaço (largura, comprimento e altura) para a formação da nalha e caracterização das isotermas, examinando dessa maneira, o perfil térmico no ambiente protegido de acordo com diferentes planos de seção e manejo realizado.

Uma simples representação gráfica das temperaturas do ar coletadas consistiu em plotar cada dado observado e construir superfícies isotérmicas a partir destes. Para cada manejo executado, foram construídas isotermas a $0,5 \mathrm{~m}$ e a $2,0 \mathrm{~m}$ de altura em relação ao nível do solo e em diferentes horas do dia.

Tomando sempre um dos ambientes protegidos como referência, foi obtido, a partir de todos os termopares instalados em cada ambiente, o valor médio de temperatura do ar no interior de cada um destes ambientes ao longo do dia, o perfil vertical de temperatura para cada manejo obtido. Valores de umidade relativa do ar em um perfil vertical com termopares instalados a $0,5 \mathrm{~m}, 1,0 \mathrm{~m}, 2,0 \mathrm{~m}, 3,0 \mathrm{~m}$ e $4,0 \mathrm{~m}$ e dados de radiação líquida e velocidade do vento do ambiente externo, também foram utilizados para estudar a variação e distribuição de temperatura do ar, umidade relativa e radiação no ambiente protegido. 
3.5. Manejo de cortinas e nebulização do ambiente protegido.

Em cada dia considerado, procurou-se verificar a variação temporal e espacial de distribuição de temperatura do ar no interior do ambiente protegido segundo o manejo executado, através da abertura e fechamento das cortinas laterais e zenitais, bem como da nebulização.

Utilizando-se dos dois ambientes protegidos, foram manejadas cortinas laterais e zenitais e aplicação da nebulização através de "foggers".

Os manejos executados foram:

- ambiente protegido com abertura de cortinas zenital e laterais a 2,5m de altura comparado com ambiente protegido controle com cortinas fechadas.

- ambiente protegido com cortinas laterais e zenital fechadas com nebulização comparado com ambiente protegido controle com cortinas laterais fechadas sem nebulização (efeito da nebulização em ambientes fechados).

- ambiente protegido com cortinas laterais abertas a 2,5m de altura e cortina zenital fechada e com nebulização comparado com ambiente protegido controle com cortinas laterais abertas a 2,5m de altura e cortina zenital fechada (efeito da nebulização em ambientes com ventilação natural).

- ambiente protegido com abertura de cortinas zenital e laterais a 1,0m de altura e nebulização comparado com ambiente protegido com cortinas fechadas sem nebulização.

- ambiente protegido com abertura de cortinas zenital e laterais a 2,0m de altura e nebulização comparado com ambiente protegido com cortinas fechadas sem nebulização.

- ambiente protegido com cortinas laterais abertas a $0,5 \mathrm{~m}$ de altura e abertura da cortina zenital comparado com ambiente protegido com cortinas laterais abertas a $0,5 \mathrm{~m}$ de altura.

- ambiente protegido com cortinas laterais abertas a 1,0m de altura e abertura da cortina zenital comparado com ambiente protegido com cortinas laterais abertas a $1,0 \mathrm{~m}$ de altura. 
- ambiente protegido com cortinas laterais abertas a 2,0m de altura e abertura da cortina zenital comparado com ambiente protegido com cortinas laterais abertas a $2,0 \mathrm{~m}$ de altura.

- ambiente protegido com cortinas laterais abertas a 3,0m de altura e abertura da cortina zenital comparado com ambiente protegido com cortinas laterais abertas a $3,0 \mathrm{~m}$ de altura.

- ambiente protegido com cortinas laterais abertas a 2,5m de altura durante todo o dia, comparado com ambiente protegido com cortinas abertas a1,0m de altura durante todo o dia.

- ambiente protegido com cortinas laterais abertas a 2,5m de altura durante todo o dia e nebulização das 9:30 as 13:30h, comparado com ambiente protegido com cortinas abertas a1,0m de altura durante todo o dia e nebulização das 9:30 as 13:30h.

Dos dados obtidos, calculou-se a entalpia do sistema e a eficiência do sistema de resfriamento adotado para cada dia considerado. Entretanto, na demonstração gráfica, foram utilizados os dias com maior valor de entalpia.

O Cálculo da entalpia foi feito pela seguinte fórmula adaptada por Villa Nova ${ }^{1}$

$$
\mathrm{H}=6,7+0,243 * \mathrm{t}+2,216 *\left(\frac{\mathrm{UR}}{100} * 10^{\frac{7,5 * \mathrm{t}}{237,3+\mathrm{t}}}-1\right)
$$

em que:

$\mathrm{H}=$ entalpia; conteúdo de calor total do ar (calor sensível + calor latente) (Kcal/kg ar seco)

$\mathrm{t}=$ temperatura do ar (bulbo seco) $\left({ }^{\circ} \mathrm{C}\right)$.

$\mathrm{UR}=$ umidade relativa $(\%)$

O cálculo da eficiência do rebaixamento de temperatura do ar no ambiente protegido, foi realizada considerando uma temperatura do ar média diária para cada um dos ambientes protegidos (testemunha e ambiente com tratamento) e feita a relação:

\footnotetext{
${ }^{1}$ VILLA NOVA, N. A. Comunicação pessoal, 1999.
} 


$$
\mathrm{E}=\frac{\mathrm{Tt}-\mathrm{T}}{\mathrm{Tt}} * 100
$$

em que:

$\mathrm{E}=$ eficiência do rebaixamento de temperatura do ar no sistema $(\%)$.

$\mathrm{Tt}=$ temperatura do ar média do ambiente testemunha $\left({ }^{\circ} \mathrm{C}\right)$.

$\mathrm{T}=$ temperatura do ar média no ambiente manejado $\left({ }^{\circ} \mathrm{C}\right)$.

A temperatura média do ar dos ambientes protegidos foi calculada considerandose todos os termopares para cada horários de armazenagem dos dados (a cada 15 minutos), conforme descrito anteriormente. Após obtida a eficiência do sistema para cada horário de armazenagem dos dados, foi obtida uma eficiência média para um período de tempo durante o manejo executado e analisado.

\subsection{Utilização de água a diferentes temperaturas.}

De 17 a 30 de dezembro de 1999 o manejo e o controle de temperatura do ar adotado consistiu da aplicação de nebulização nos dois ambientes protegidos, sendo que em um deles foi aspergindo água a temperatura ambiente como testemunha e, no outro ambiente protegido, a nebulização foi aspergindo água resfriada por meio de um motor de refrigeração equivalente ao de um "freezer" de $0,3 \mathrm{~m}^{3}$. As nebulizações foram feitas com água à diferentes temperaturas, cujo gradiente de temperatura variou de 2,0 a $6,0^{\circ} \mathrm{C}$ para se verificar a eficácia no rebaixamento da temperatura do ar. As cortinas laterais permaneceram abertas todo o tempo para permitir uma maior ventilação, resfriamento e renovação do ar, procurando manter uma umidade relativa mais baixa no interior do ambiente protegido.

Em cada tratamento foram avaliadas a distribuição espacial da temperatura do ar (temperatura do bulbo seco) no interior dos ambientes protegidos. 
Esse procedimento foi repetido, no período de 09 de janeiro a 06 de fevereiro de 2000 e 28 de abril a 19 de maio de 2000, porém com cortinas laterais fechadas e gradientes de temperatura da água variando de 15,0 a $20,0^{\circ} \mathrm{C}$. 


\section{RESULTADOS E DISCUSSÃO}

A análise dos resultados para os diferentes manejos de cortinas laterais e zenitais e nebulização realizados no ambiente protegido estão apresentados em itens de acordo com os tratamentos aplicados. A análise foi realizada de modo a obter um entendimento do processo ocorrido durante o decorrer do dia e de forma mais específica através da representação por meio de isotermas. Entretanto, inicialmente o ambiente protegido foi caracterizado de forma a se identificar a variação dos elementos meteorológicos, bem como a distribuição de temperatura do ar, umidade relativa do ar e radiação líquida no ambiente protegido em dias característicos. Analisando-se as medidas de temperatura do ar feitas através de todos os termopares instalados no ambiente, determinou-se o(s) termopar(es), bem como sua posição que representasse a temperatura média do ar deste ambiente.

4.1. Variação da temperatura e umidade relativa do ar e da radiação líquida.

Durante o período diurno, com o aumento da temperatura do ar a umidade relativa do ar diminui no ambiente protegido, chegando a valores mínimos quando a temperatura do ar atinge o seu ponto máximo. Esse valor, portanto depende da quantidade de água disponível na atmosfera nesse dia. Durante a noite, a umidade relativa aumenta, chegando próxima a 100,0\% até antes do nascer do sol, devido à queda de temperatura do ar verificada (Figura 8). 

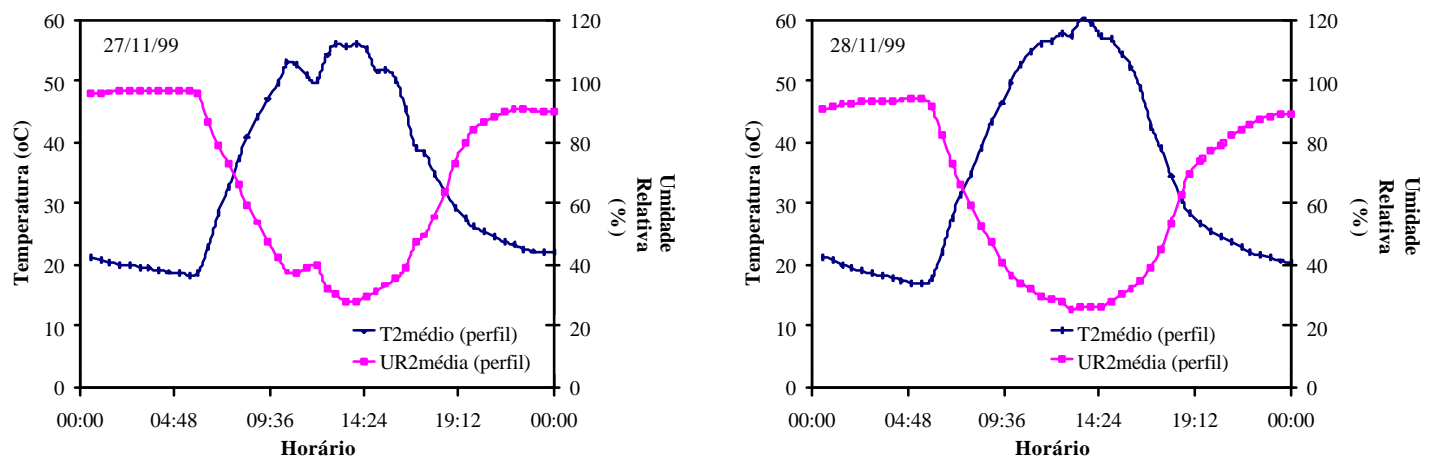

Figura 8: Umidade relativa e temperatura do ar no ambiente protegido em dias de céu limpo (27 e 28/11/99).

Nos ambientes protegidos com as cortinas laterais e zenitais fechadas, observou-se temperatura máxima do ar de $56,0^{\circ} \mathrm{C}$ e $60,0^{\circ} \mathrm{C}$ para os dias 27 e 28/11/99, respectivamente, atingida no período entre 12:30 e 14:30h. Nos dias ensolarados e quentes de primavera-verão, logo após o nascer do sol, as temperaturas começam a se elevar atingindo valores considerados acima da temperatura ótima para a maioria das culturas, principalmente as folhosas e outras culturas tipicamente de inverno e cultivadas fora de época. Entretanto, a temperatura ótima dentro do ambiente protegido vai depender da espécie a ser cultivada e em alguns casos, do estágio de desenvolvimento da planta. Por exemplo, no caso do pimentão, as temperaturas mais favoráveis na época de formação de mudas são de 26,0 a $30,0^{\circ} \mathrm{C}$; aos 90 dias após a semeadura, na frutificação, é de $21,0^{\circ} \mathrm{C}$; após 105 dias, em plena produção, $19,0^{\circ} \mathrm{C}$ e aos 150 dias, $9,0^{\circ} \mathrm{C}$. Durante a germinação e a formação da muda, a planta é mais sensível ao frio exigindo temperaturas mais elevadas m ar e no solo (Filgueira, 1982). Deste modo, a temperatura do ar ideal no ambiente protegido, vai depender da fase fenológica da cultura e da época do ano.

A definição do local onde se deve instalar um determinado sensor no interior de um ambiente protegido é sempre questionável, uma vez que, para fins práticos, se quer conhecer valores médios de um elemento meteorológico.

Analisando-se os 78 pontos de medição de temperatura do ar instalados no ambiente protegido, procurou-se os pontos que representassem a temperatura média de 
todo ambiente. Observou-se numa análise preliminar que vários pontos se aproximam da média, entretanto, dois pontos são bem característicos. Esses pontos estão localizados nas posições 9 e 10 (Figura 3), a 1,0m de altura em relação ao nível do solo e são representados pelos termopares T36 e T41, respectivamente. Esses termopares se encontram no centro geométrico do ambiente protegido onde há maior uniformidade na distribuição de temperatura e menor influência da temperatura do ar externa nas laterais. Na Figura 9 observa-se a temperatura do ar obtida nesses termopares, nos dias 14, 15, 27 e 28/11/99, os quais representaram a temperatura média do ar no decorrer do dia.
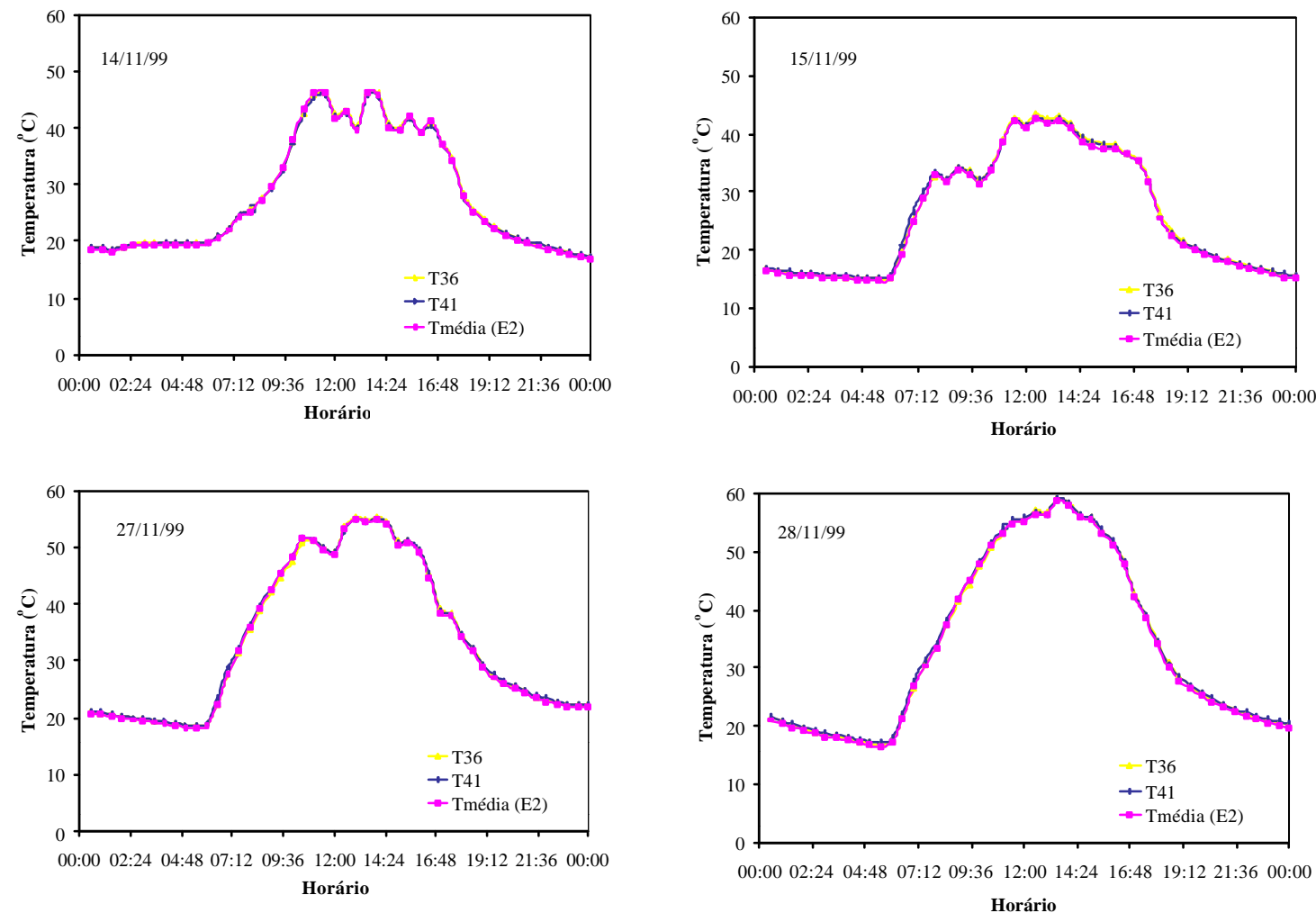

Figura 9. Temperatura média do ar no ambiente protegido e temperatura do ar nos pontos T36 e T41 nos dias 14 e 15/11/99 (dia nublado) e nos dias 27 e 28/11/99 (céu limpo).

Considerando-se a temperatura média do ar como padrão aplicou-se o teste $\mathrm{t}$ comparando essa média com a temperatura do ar obtida pelos termopares T36 e T41. 
Para cada um dos termopares em todos os dias analisados o teste $t$ não foi significativo e portanto as médias não diferiram entre si e podem ser consideradas praticamente iguais.

A porcentagem de radiação que passa pela cobertura do ambiente protegido varia em função do tipo de material utilizado e do grau de deposição de poeira sobre ele. Segundo Cermeño (1994), a quantidade de radiação luminosa que penetra no interior de um ambiente protegido depende do fluxo que chega à cobertura, do fluxo refletido, do fluxo absorvido pelo material de cobertura, do poder de dispersão do material de cobertura, do fluxo absorvido pelo solo e do fluxo refletido pelo solo e do que é perdido para o exterior pela cobertura. Na Figura 10 observa-se a variação do saldo de radiação externa e interna nos ambientes protegidos para os dias 17, 18, 27 e 28/11/99, sendo a porcentagem de radiação líquida no ambiente protegido em relação a externa, para estes dias, de 53,9\%, $57,4 \%, 47,7 \%$ e $53,0 \%$, respectivamente. O teste $\mathrm{t}$ aplicado para o saldo de radiação nesses dias foram significativos a 1,0\% de probabilidade. Folegatti et al. (1997), observaram valores médios de perda de 37,0\% da radiação solar global por reflexão ou absorção do plástico (polietileno de baixa densidade de $0,15 \mathrm{~mm}$ de espessura) em ambientes protegidos cultivados com crisântemo.

A radiação solar no ambiente protegido é parcialmente absorvida pelo solo, plantas e objetos, sendo parte convertida em energia térmica (radiação de onda longa). Esta radiação térmica é irradiada para o espaço e, ao atingir algum material opaco, fica retido nesse ambiente, propiciando uma elevação da temperatura (efeito estufa) (Tapia, 1981).

Além das perdas de radiação térmica, o ambiente protegido também perde energia por processos de condução-convecção através da cobertura, pelas aberturas existentes. A céu aberto, também há grande perda de radiação térmica, porém, os movimentos horizontais e verticais de massa de ar podem transportar calor, aquecendo o ambiente externo por mistura de camadas de ar, o que não ocorre no interior de ambientes protegidos, que quando fechados impede a ação dos ventos. Desta forma, é possível a ocorrência de temperaturas internas inferiores as verificadas externamente (Farias et al., 1993). 

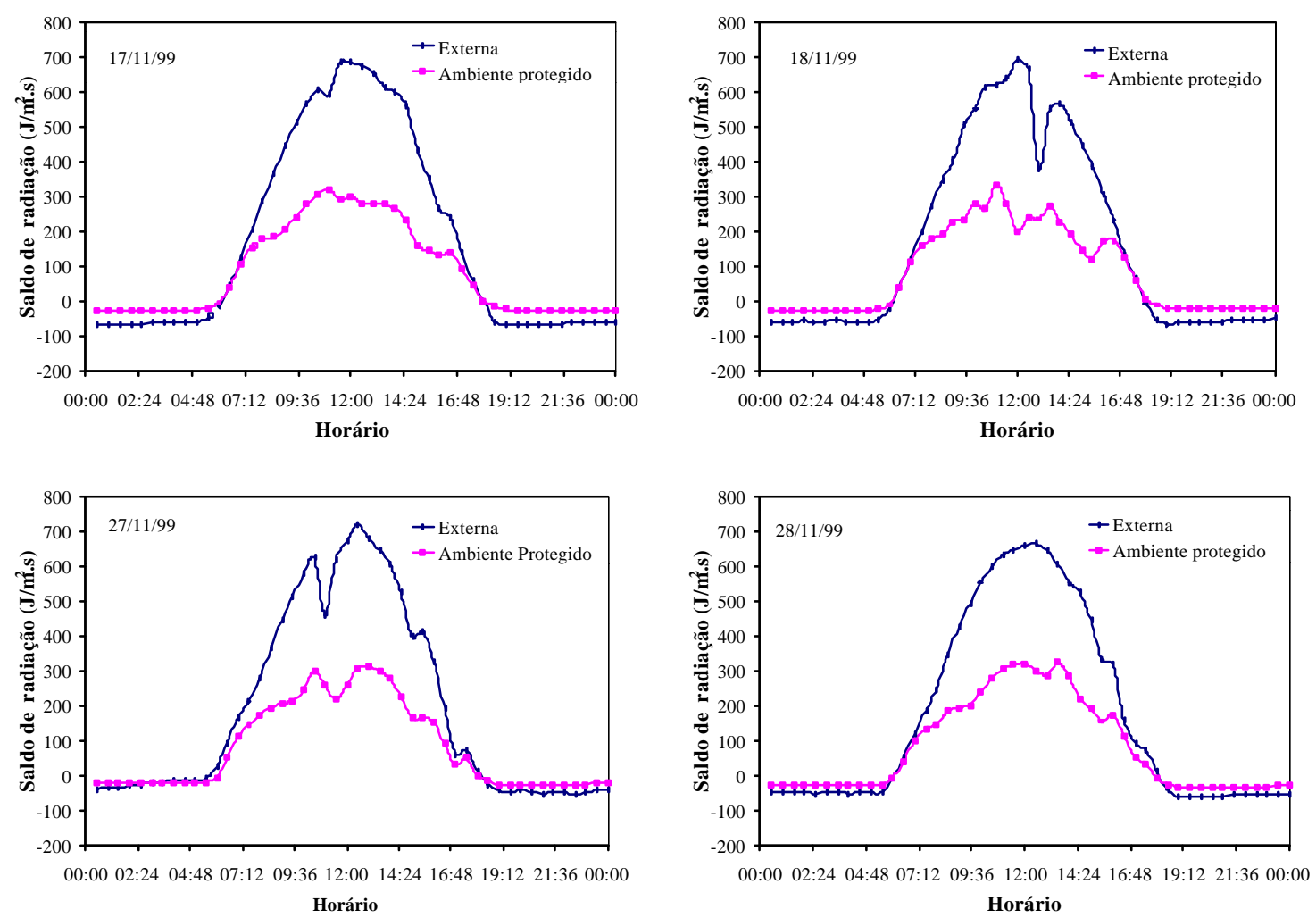

Figura 10. Saldo de radiação externa e no ambiente protegido nos dias 17, 18, 27 e 28/11/99.

Segundo Kittas (1996), a temperatura do ar no ambiente protegido durante a noite, pode ser assumida como sendo igual a temperatura do ar no ambiente externo, mas, durante o dia a temperatura do ar dentro do ambiente protegido aumenta significativamente. $\mathrm{Na}$ Figura 11, estão representadas as temperaturas médias internas nos ambientes protegidos 1 e 2 e a temperatura externa durante dias nublados e dias claros. Em dias nublados e em dias claros, observa-se que a temperatura do ar no ambiente protegido esteve acima da temperatura do ar externa, ao longo do dia, chegando à diferença de até $30,0^{\circ} \mathrm{C}$. As temperaturas internas mais elevadas foram observadas entre 12:00h e 16:00h.

As diferenças de temperaturas do ar entre o ambiente protegido 1 e o ambiente protegido 2 nos dias nublados (14 e 15/11/99) e nos dias de céu limpo (27 e 28/11/99) não foram significativas pelo teste $t$, mas as diferenças de temperatura do ar nesses dias entre as 
temperaturas do ar dos ambientes protegidos e as temperaturas do ar no ambiente externo foram significativas a $1,0 \%$ de probabilidade.
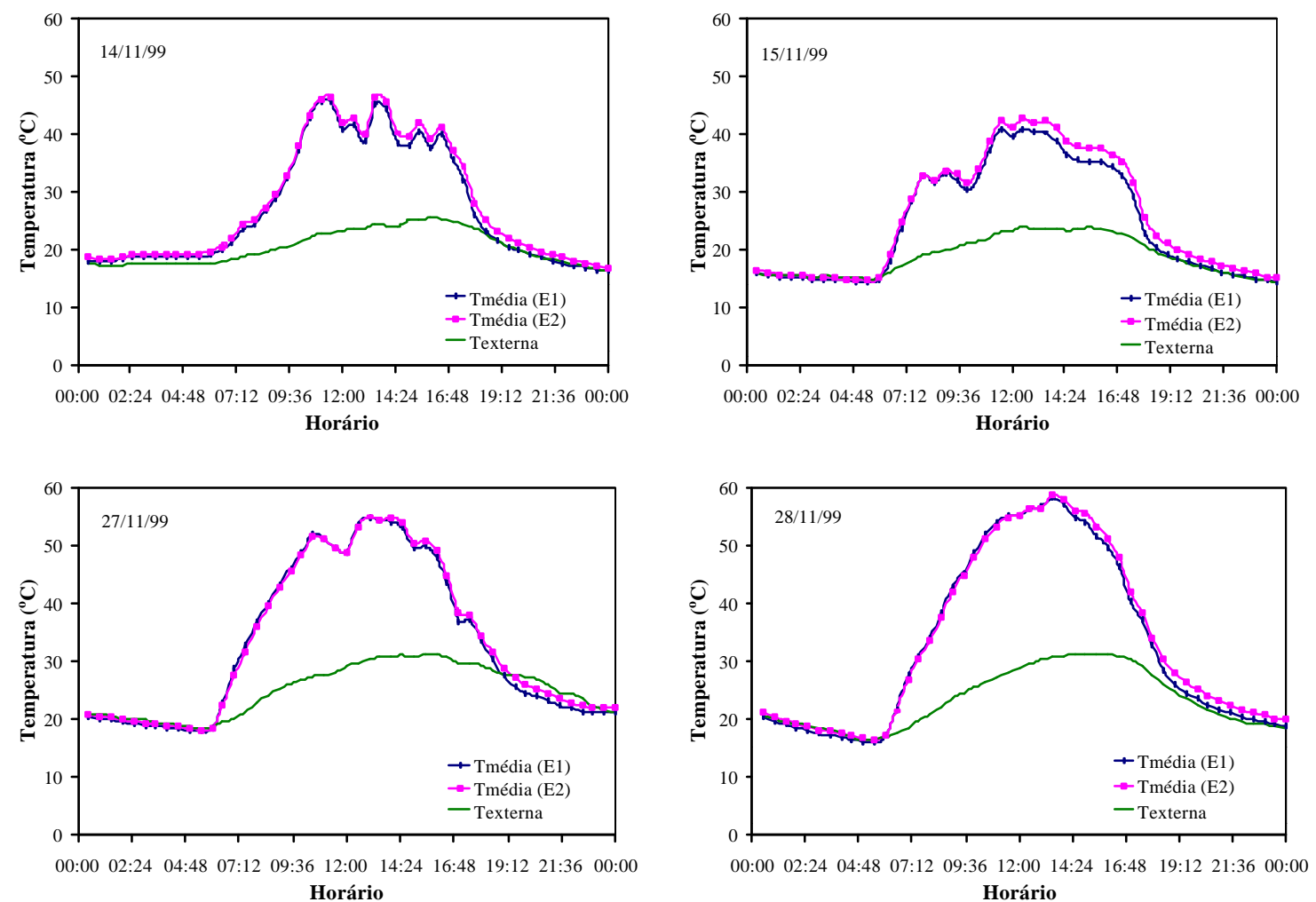

Figura 11. Variação da temperatura do ar nos dois ambientes protegidos e no ambiente externo em dias nublados (14 e 15/11/99) e dias de céu limpo (27 e 28/11/99).

4.2. Efeito do manejo de cortinas e nebulização em ambientes protegidos

O controle microclimático eficiente no verão é um dos maiores desafios para produtores que utilizam o cultivo em ambiente protegido para obter produtos de melhor qualidade e fora da época convencional. O cultivo no verão, apesar de ser favorecido pelo efeito "guarda-chuva" proporcionado pelo cultivo protegido, enfrenta problemas sérios de temperaturas do ar elevadas, que pode causar até a morte da planta. Ambientes protegidos com pé-direito baixo apresentam maiores problemas com a elevação de temperatura e seu controle é mais difícil. Nesse trabalho passaremos a descrever o efeito 
das técnicas de resfriamento e do manejo das cortinas no microclima dos ambientes protegidos.

4.2.1. Efeito da abertura de cortinas laterais e zenitais na temperatura do ar.

\subsubsection{Variação da temperatura do ar}

Mantendo-se um dos ambientes protegidos com as cortinas fechadas (E1) e outro com manejo de abertura e fechamento de cortinas laterais e zenitais (E2), comparou-se à variação da temperatura média do ar nos dois ambientes. Na Figura 12, observa-se a redução da temperatura média do ar no ambiente protegido (E2) onde as cortinas foram abertas, em comparação com o ambiente (E1) para o dia 23/11/99. Às 9:00h, foram abertas as cortinas laterais do ambiente protegido (E2) a 2,5m de altura em relação ao nível do solo e, às 16:00h, foram fechadas. Nesse período, comparando-se a temperatura média do ar de E1 com E2 obtida a cada 15 minutos, a redução de temperatura média do ar foi significativa a 1,0\% de probabilidade pelo teste $\mathrm{t}$. A temperatura média do ar nesse intervalo, para o ambiente testemunha (E1), foi de $46,9^{\circ} \mathrm{C}$ e a média para o ambiente com abertura de cortinas foi de $35,5^{\circ} \mathrm{C}$, correspondendo a uma redução de $11,4^{\circ} \mathrm{C}$ ou $24,2 \%$ da temperatura média do ar. A temperatura do ar externa média para esse intervalo foi de $27,9^{\circ} \mathrm{C}$, ficando o ambiente protegido com cortinas abertas com temperatura do ar $27,4 \%$ superior a externa e o ambiente testemunha com $68,17 \%$.

Na Figura 13, observa-se a redução da temperatura média do ar no ambiente protegido onde se manejou as cortinas (E2) em comparação com o ambiente testemunha (E1) no dia 30/11/99. A cortina zenital foi aberta às $11: 00 \mathrm{~h}$ e às $12: 30 \mathrm{~h}$ as cortinas laterais do ambiente protegido E1 foram abertas a 2,0m de altura em relação ao nível do solo, e às 14:00h, foram fechadas as cortinas laterais e a zenital. Nesse período, a redução de temperatura do ar no ambiente protegido manejado foi significativa a 1,0\% de probabilidade pelo teste $\mathrm{t}$ 


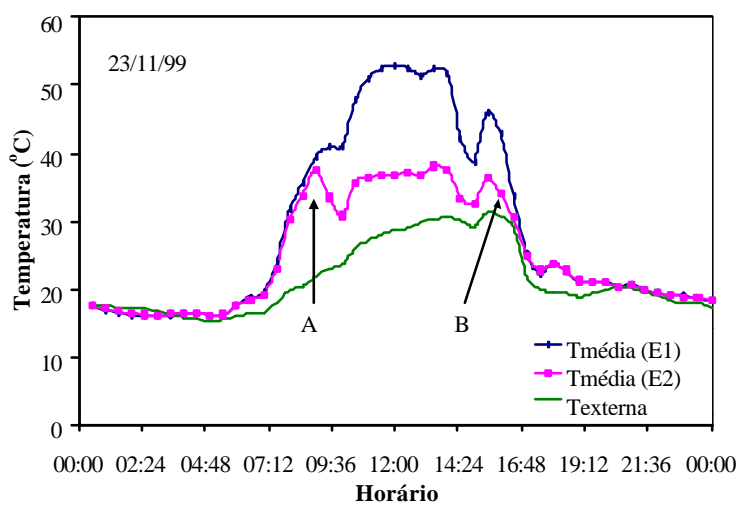

A - abertura das cortinas laterais a $2,5 \mathrm{~m}$ de altura em relação ao nível do solo (9:00h).

B - cortinas fechadas (16:00h)

Figura 12. Variação da temperatura média do a no ambiente protegido com as cortinas fechadas (E1), no ambiente protegido com manejo das cortinas laterais (E2) e no ambiente externo, no dia 23/11/99.

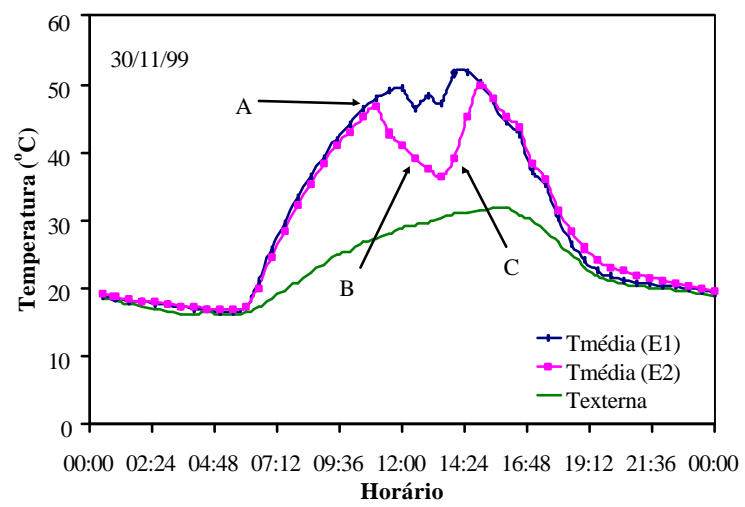

A - abertura da cortina zenital (11:00h)

B - abertura das cortinas laterais a 2,0m em relação ao nível do solo (12:30h)

C - cortinas laterais e zenital fechadas (14:00h)

Figura 13. Variação da temperatura média do ar no ambiente protegido com as cortinas fechadas (E1), no ambiente protegido com manejo das cortinas laterais e zenital (E2) e no ambiente externo, no dia 30/11/99.

A temperatura média do ar nesse intervalo no ambiente testemunha (E1) foi de $49,1^{\circ} \mathrm{C}$ e no ambiente com as cortinas abertas foi de $40,2^{\circ} \mathrm{C}$. A diferença de $8,9^{\circ} \mathrm{C}$ representa uma temperatura média do ar 18,2\% inferior. A temperatura média do ar externa para esse intervalo foi de $29,6^{\circ} \mathrm{C}$, ficando o ambiente protegido com manejo de cortinas com temperatura do ar $35,68 \%$ superior à temperatura externa e o ambiente testemunha, $65,8 \%$.

Nesses dias, a relação entre a temperatura do ar externa e a temperatura do ar no ambiente protegido testemunha manteve-se praticamente a mesma, porém, quando se 
inicia a abertura de cortinas tardiamente há maior acúmulo de energia calorífica no ambiente pela absorção de calor pelo solo e pelas peças estruturais do ambiente protegido, ocasionando elevação da temperatura média do ar e a redução da temperatura do ar torna-se menos eficiente. Outro fator que influi na redução da temperatura é a direção e velocidade do vento, as quais não foram mensuradas no ambiente protegido. No entanto, a velocidade média do vento no ambiente externo durante o período de cortinas abertas dos ambientes protegidos foi de $1,87 \mathrm{~m} / \mathrm{s}$ e $1,53 \mathrm{~m} / \mathrm{s}$ para os dias 23 e 30/11/99, respectivamente.

\subsubsection{Variação vertical e horizontal de temperatura do ar.}

Na Figura 14a observa-se o perfil vertical de temperatura média do ar no dia 23/11/99 no ambiente protegido onde houve abertura de cortinas laterais a 2,5m de altura em relação ao nível do solo. Na Figura 14b observa-se os perfis de distribuição vertical de temperatura média do ar no ambiente protegido controle, com cortinas fechadas. Às 8:30h, representa o horário anterior à abertura das cortinas laterais, quando os dois ambientes protegidos apresentavam condições de distribuição de temperatura do ar próximas a $33,5^{\circ} \mathrm{C}$ a $0,5 \mathrm{~m}$ de altura e ao redor de $37,0^{\circ} \mathrm{C}$ a $4,0 \mathrm{~m}$. O perfil determinado às 9:00h, representa a média de temperatura do ar no momento da abertura das cortinas laterais. Nesse momento, a temperatura média do ar no ambiente protegido variou de $37,0^{\circ} \mathrm{C}$ a $0,5 \mathrm{~m}$ de altura em relação ao nível do solo a $41,5^{\circ} \mathrm{C}$ a $4,0 \mathrm{~m}$.

No perfil determinado às $12: 00 \mathrm{~h}$ na Figura 14a comparando com a Figura 14b, notou-se o efeito da redução de temperatura do ar no ambiente protegido pela abertura das cortinas laterais a 2,5m de altura (ventilação natural). Nesse horário, com as cortinas abertas, a temperatura média do ar variou de $34,5^{\circ} \mathrm{C}(0,5 \mathrm{~m}$ de altura $)$ a $41,5^{\circ} \mathrm{C}(4,0 \mathrm{~m}$ de altura) no ambiente protegido manejado em comparação com o ambiente protegido controle que variou de $50,0^{\circ} \mathrm{C}$ a $55,5^{\circ} \mathrm{C}$. A redução de temperatura média do ar nesse horário foi de aproximadamente $15,0^{\circ} \mathrm{C}$ quando comparada com o ambiente controle (com valores médios de temperatura no perfil de $38,0^{\circ} \mathrm{C}$ no ambiente protegido com as cortinas abertas e de $52,8^{\circ} \mathrm{C}$ no ambiente protegido testemunha). 

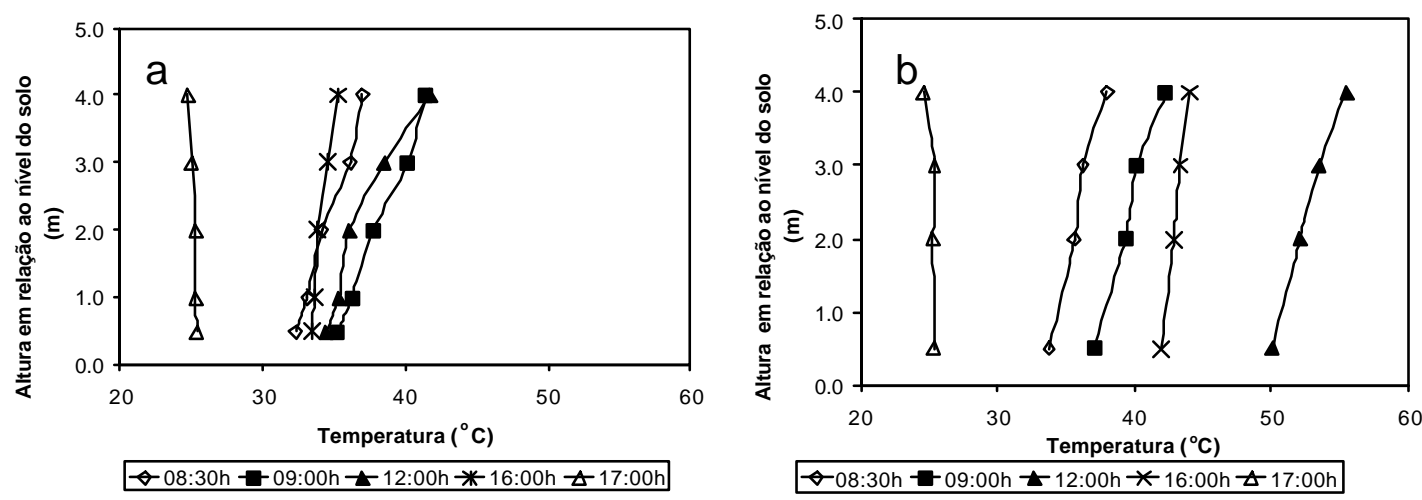

Figura 14. Perfil vertical de temperatura do ar no ambiente protegido com abertura de cortinas laterais a 2,5m de altura em relação ao nível do solo (a) e ambiente protegido testemunha (b), antes da abertura (8:30h), no momento da abertura (9:00h), com as cortinas abertas (12:00h), no momento do fechamento das cortinas laterais (16:00h) e uma hora após o fechamento das cortinas (17:00h), no dia 23/11/99.

O perfil de temperatura do ar obtido às $16: 00 \mathrm{~h}$ representa a temperatura média do ar antes do fechamento das cortinas laterais. Nesse horário a temperatura média do ar no perfil variou de 33,0 a $35,0^{\circ} \mathrm{C}$ no ambiente protegido com as cortinas abertas e de 42,0 a $44,0^{\circ} \mathrm{C}$ no ambiente protegido controle, de $0,5 \mathrm{~m}$ a $4,0 \mathrm{~m}$ de altura em relação ao nível do solo. O perfil das 17:00h representa o período após o fechamento das cortinas laterais. No ambiente protegido manejado e no controle, a temperatura média no perfil variou de 25,4 a $25,0^{\circ} \mathrm{C}$ a 0,5 e a $4,0 \mathrm{~m}$, respectivamente. A pequena variação de temperatura média do ar nos perfis nos horários de 16 e 17:00h foi em função do aquecimento da cobertura plástica pela radiação solar e da transmissão de calor através dessa para o ar do ambiente protegido. Esta interferência é pequena e não causa o gradiente de temperatura que ocorre nos períodos mais quentes.

Na Figura 15 estão representadas as isotermas a 0,5m de altura no dia 23/11/99 para o ambiente protegido com as cortinas laterais abertas (15a, 15b, 15c e 15d) e o ambiente protegido controle (15e, 15f, 15g e 15h) para os horários de 9:00h (15a e 15e), 12:00h (15b e 15f), 16:00h (15c e 15g) e 17:00h (15d e 15h). 

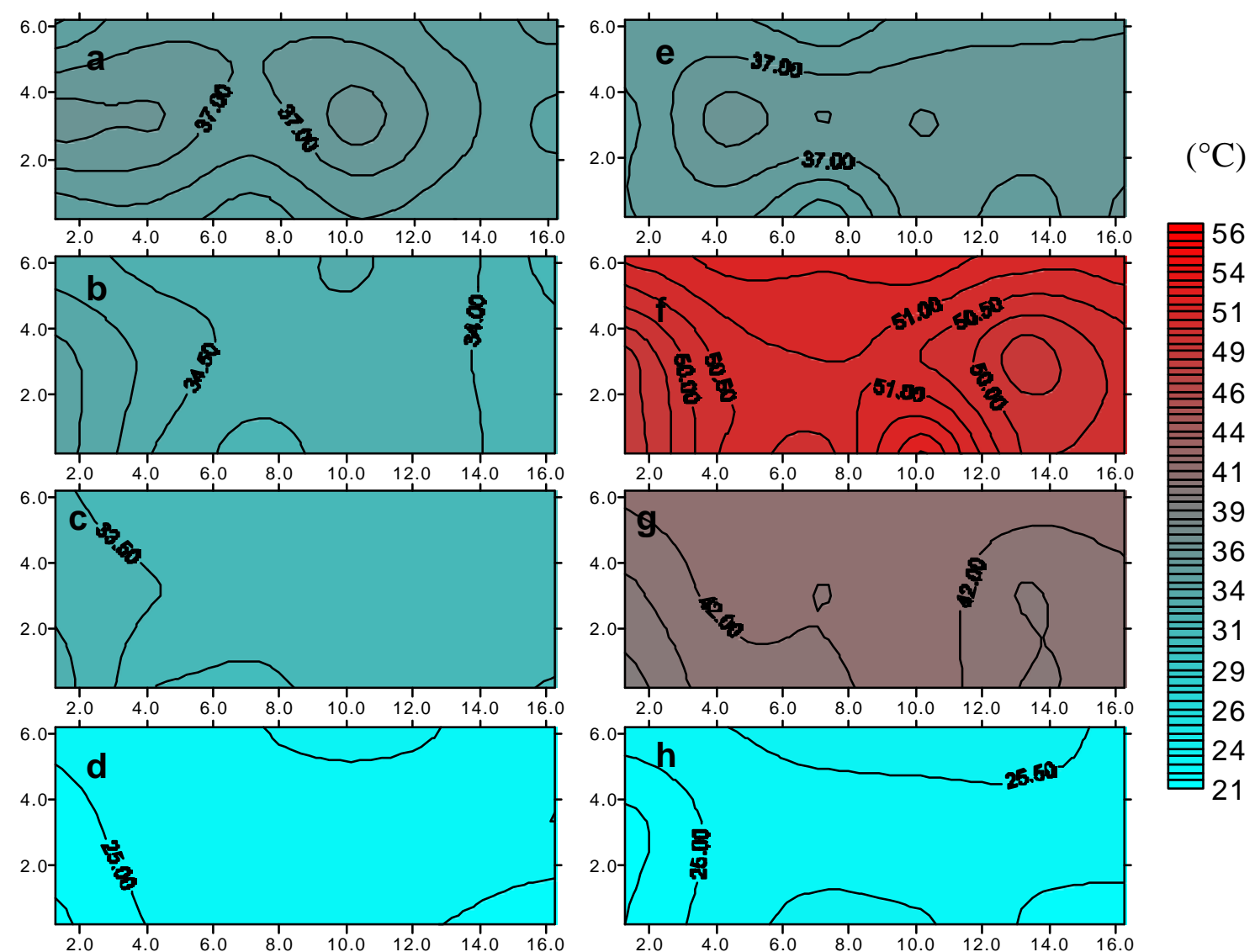

Figura 15. Distribuição de temperatura do ar no ambiente protegido com abertura de cortinas laterais (a, b, c e d) e no ambiente protegido controle (e, f, g e h) para os horários de 9:00h (a e e), 12:00h (b e f), 16:00h (c e g), 17:00h (d e h) a 0,5m de altura no dia 23/11/99. O eixo x representa a largura (m) e y o comprimento do ambiente protegido (m).

Às 9:00h, a variação de temperatura em diferentes pontos de amostragem nos ambientes protegidos, não tiveram grande amplitude, com variação de cerca de $1,0^{\circ} \mathrm{C}$. Às 12:00h, período de grande elevação de temperatura no ambiente protegido (Figuras $15 b$ e $15 f)$, houve efeito da abertura de cortinas laterais na redução de temperatura do ar no ambiente protegido quando comparado com o ambiente protegido controle. A temperatura do ar no ambiente protegido variou de 34,0 a $35,5^{\circ} \mathrm{C}$ (Figura $15 \mathrm{~b}$ ) enquanto que no ambiente protegido controle (Figura 15f), a variação foi de 49,0 a $51,5^{\circ} \mathrm{C}$, reduzindo cerca de 31,9\%, com temperaturas do ar médias, a 0,5m de altura, de 34,4 e 
$50,5^{\circ} \mathrm{C}$, respectivamente. A distribuição de temperatura do ar no ambiente protegido com abertura de cortinas laterais foi praticamente homogênea, porém, com temperaturas ligeiramente superiores na direção oeste.

Nas Figuras 15c e 15g estão representadas as distribuições horizontais de temperatura do ar no ambiente protegido no momento do fechamento das cortinas laterais às 16:00h. A distribuição de temperatura do ar era praticamente homogênea, com temperatura média de $33,5^{\circ} \mathrm{C}$. Comparando com as medidas no ambiente protegido controle, a temperatura média do ar variou de 41,0 a $42,0^{\circ} \mathrm{C}$, com média de temperatura do perfil de $41,9^{\circ} \mathrm{C}$, obtendo-se redução da temperatura de $20,0 \%$.

Nas Figuras 15d e 15h, estão representados os perfis de distribuição horizontal nos ambientes protegidos às 17:00h, uma hora após o fechamento das cortinas laterais. Nos ambientes protegidos, a distribuição de temperatura do ar teve pouca amplitude de variação, sendo que as temperaturas médias do ar nos dois ambientes protegidos foram 25,2 e $25,4^{\circ} \mathrm{C}$ para o ambiente com manejo de cortinas e o ambiente controle, respectivamente.

$\mathrm{Na}$ Figura 16, estão representadas as isotermas a 2,0m de altura no dia 23/11/99 para o ambiente protegido com abertura de cortinas laterais (16a, 16b, 16c e 16d) e o ambiente protegido controle (16e, 16f, 16g e 16h) para os horários de 9:00h (16a e 16e), 12:00h (16b e 16f), 16:0h (16c e 16g) e 17:00h (16d e 16h).

A 2,0m de altura em relação ao nível do solo (Figura 16) ocorreu elevação da temperatura do ar quando comparado com as isotermas determinadas a 0,5m de altura (Figura 15), principalmente às 9 e 12:00h. Às 16 e 17:00h, praticamente se manteve a mesma média de temperatura do ar que a $0,5 \mathrm{~m}$. As temperaturas do ar no ambiente protegido com abertura de cortinas laterais às 9:00h (Figura 16a) variaram de 38,0 a $38,5^{\circ} \mathrm{C}$ e de 38,0 a $39,5^{\circ} \mathrm{C}$ no ambiente protegido controle (Figura 16e), com médias de temperatura do ar de 38,5 e $38,6^{\circ} \mathrm{C}$, respectivamente. Às $12: 00 \mathrm{~h}$, a variação foi de 36,0 a $38,0^{\circ} \mathrm{C}$ no ambiente protegido com ventilação natural e de 52,0 a $53,5^{\circ} \mathrm{C}$ no ambiente protegido com as cortinas fechadas, com temperaturas médias do perfil de 36,7 e $52,9^{\circ} \mathrm{C}$, respectivamente, obtendo-se redução de temperatura do ar de 30,6\%. 

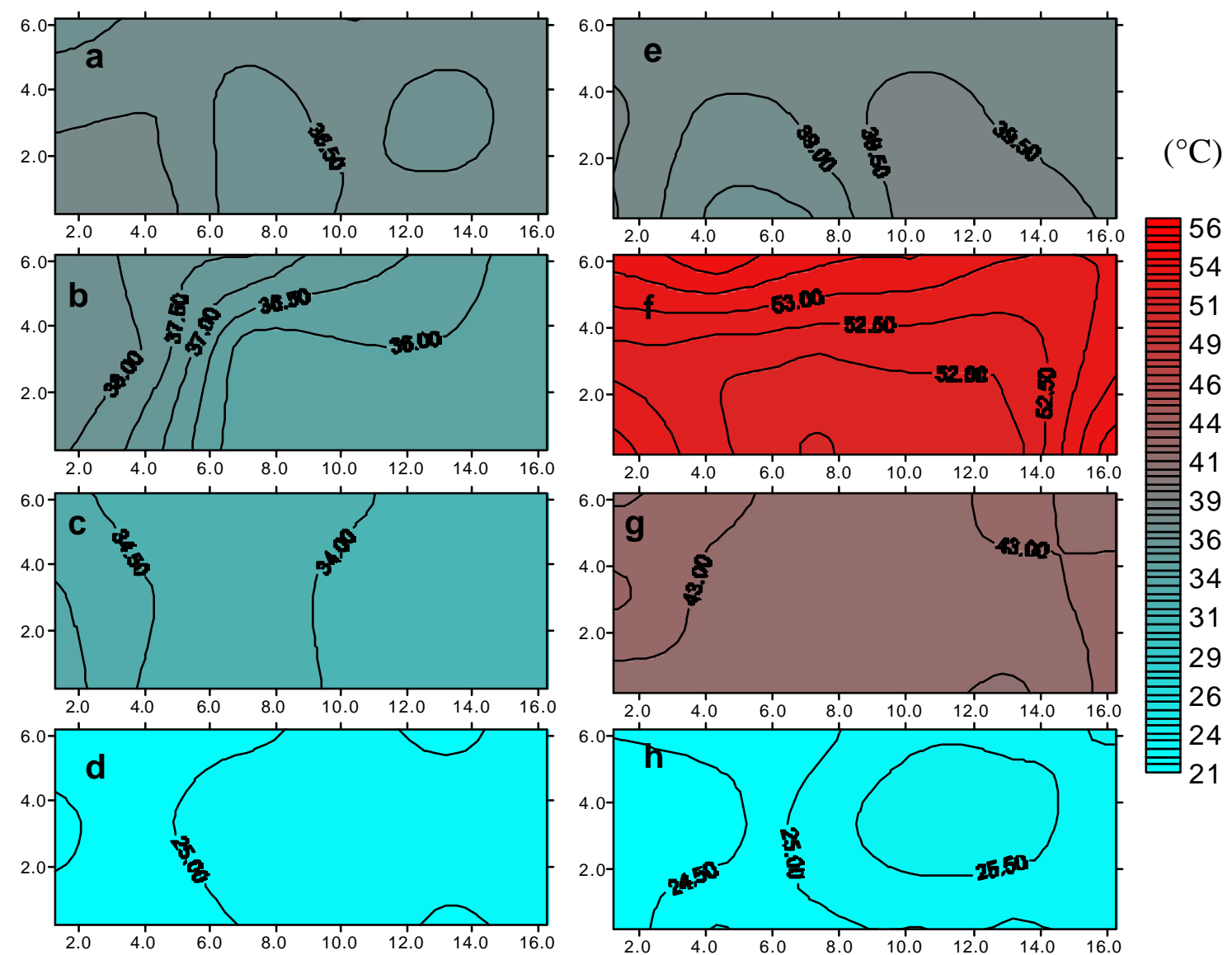

Figura 16. Distribuição de temperatura do ar no ambiente protegido com abertura de cortinas laterais (a, b, c e d) e no ambiente protegido controle (e, f, g e h) para os horários de 9:00h (a e e), 12:00h (b e f), 16:00h (c e g), 17:00h (d e h) a 2,0m de altura no dia 23/11/99. O eixo x representa a largura (m) e y o comprimento do ambiente protegido (m).

Às 17:00h, entretanto, não houve aumento de temperatura do ar com a altura, mantendo-se a distribuição de temperatura do ar com valores muito próximos das observadas a $0,5 \mathrm{~m}$. As temperaturas do ar variaram de 34,0 a $34,5^{\circ} \mathrm{C}$ no ambiente protegido com cortinas abertas e de 42,5 a $43,0^{\circ} \mathrm{C}$ no ambiente protegido controle, com temperaturas médias de 34,2 e $42,9^{\circ} \mathrm{C}$, respectivamente. A redução de temperatura do ar no ambiente protegido com cortinas abertas em relação ao ambiente protegido controle foi de $20,3 \%$. Entretanto, às 17:00h, uma hora após o fechamento das cortinas laterais no ambiente protegido, a distribuição e a amplitude de temperatura do ar nos ambientes 
protegidos foram praticamente a mesma, tendo como média de temperatura do ar de $25,0^{\circ} \mathrm{C}$, nos dois ambientes.

$\mathrm{O}$ ambiente protegido com cortinas fechadas atingiu temperaturas impróprias para o desenvolvimento das culturas. De acordo com Andriolo (1999) o manejo das temperaturas excessivamente elevadas pode ser feita pela ventilação do ambiente protegido, como observada nas Figuras 12, 13, 14, 15 e 16. A renovação do ar no ambiente protegido manejado foi obtida basicamente das diferenças de pressão entre o ar localizado no interior e no exterior do ambiente.

4.2.2. Nebulização e redução da temperatura do ar no ambiente protegido.

O resfriamento evaporativo é um dos métodos mais eficientes utilizado na redução da temperatura do ar em ambientes protegidos. A diminuição da temperatura do ar em ambientes protegidos com nebulizadores foi avaliada pela comparação da temperatura média do ar durante o dia em dois ambientes protegidos similares, sendo que em um deles utilizour-se o sistema de nebulização.

\subsubsection{Cortinas fechadas.}

\subsection{Variação da temperatura do ar.}

Para se verificar o efeito da nebulização na redução da temperatura do ar no ambiente protegido, sem o efeito da ação do vento, foram analisados dias em que as cortinas laterais e zenitais dos ambientes protegidos permaneceram fechadas. Nesta situação, há uma grande elevação da temperatura do ar no ambiente protegido. Na Figura 17 observa-se a variação da temperatura média do ar durante o dia 07/11/99 nos dois ambientes. A maior elevação da temperatura corresponde ao ambiente que permaneceu fechado e não houve nebulização (E2). Às 9:00h no dia 07/11/99, acionouse o nebulizador no ambiente E1, com nebulização intermitente. $\mathrm{O}$ nebulizador permaneceu acionado por 15 minutos e desligado pelos 15 minutos seguintes e assim sucessivamente até às 16:00h, quando o nebulizador foi desligado. 
A umidade relativa média do ar durante o dia no ambiente sem nebulização foi de $38,0 \%$ e no ambiente em que houve nebulização foi de $71,8 \%$. O incremento na umidade relativa proporcionada pela evaporação da água adicionada ao ambiente pelo nebulizador foi de $89,0 \%$. Essa elevação na umidade relativa do ar foi devido ao fato das cortinas laterais estarem fechadas e, portanto, impedindo a renovação de ar no interior do ambiente protegido e acumulando água evaporada.

A diferença de temperatura do ar entre o ambiente protegido nebulizado e o não nebulizado durante o período manejado foi significativa a 1,0\% de probabilidade pelo teste t.

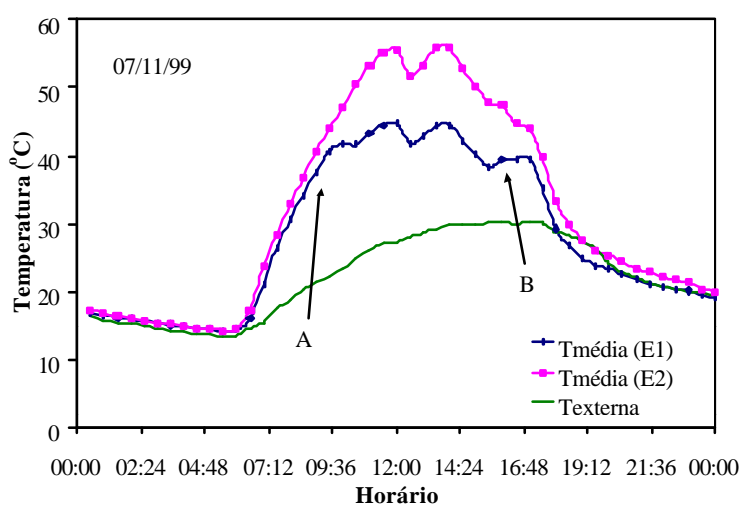

A $\quad$ nebulização início da intermitente (9:00h)

B - final da nebulização (16:00h)

Figura 17. Variação da temperatura média do ar no ambiente protegido com acionamento do nebulizador (E1), no ambiente protegido testemunha (E2) e no ambiente externo, no dia 07/11/99.

Durante o período de acionamento do nebulizador a temperatura média do ar foi de $50,8^{\circ} \mathrm{C}$ no ambiente testemunha e de $41,8^{\circ} \mathrm{C}$ no ambiente com nebulização. Houve redução da temperatura por efeito da evaporação de $9,0^{\circ} \mathrm{C}$, ficando o ambiente com temperatura média do ar de 17,6\% abaixo da testemunha. A média da temperatura externa para esse intervalo foi de $27,2^{\circ} \mathrm{C}$, ficando o ambiente protegido manejado com uma temperatura 53,9\% superior a externa e o ambiente testemunha com 86,9\% acima da temperatura externa. Esses resultados concordam com Montero et al. (1990) que encontraram redução na temperatura do ar de $3,0^{\circ} \mathrm{C}$, na média devido ao resfriamento 
evaporativo dos ambientes protegidos, quando comparado com o ambiente protegido controle e uma redução máxima de $5,0^{\circ} \mathrm{C}$ em dias de sol.

Na Figura 18 observa-se a distribuição da temperatura média do ar durante o dia 17/11/99 nos dois ambientes protegidos. O maior aumento da temperatura do ar corresponde ao ambiente que permaneceu fechado e não houve nebulização (E1). No dia 17/11/99 às 11:00h, acionou-se o nebulizador no ambiente protegido E2. A nebulização também foi intermitente permanecendo acionado por 15 minutos e desligado pelos 15 minutos seguintes e assim sucessivamente até às 15:30hs, quando o nebulizador foi desligado.

A umidade relativa média do ar durante o dia no ambiente sem nebulização foi de $46,0 \%$ e no ambiente em que houve nebulização foi de $63,5 \%$. O aumento nesse dia da umidade relativa no ambiente pelo acionamento do nebulizador foi de $38,1 \%$.

As diferenças entre as temperaturas do ar no ambiente protegido nebulizado e as temperaturas do ar no ambiente protegido sem nebulização foram significativas a 1,0\% de probabilidade pelo teste t. Durante o período de acionamento do nebulizador a temperatura média foi de $50,4^{\circ} \mathrm{C}$ no ambiente testemunha e de $41,7^{\circ} \mathrm{C}$ no ambiente com nebulização. Houve uma diminuição de temperatura por efeito da evaporação de $8,7^{\circ} \mathrm{C}$, ficando o ambiente com temperatura média cerca de 17,3\% abaixo da testemunha. A temperatura média externa do ar para esse intervalo foi de $26,0^{\circ} \mathrm{C}$, ficando o ambiente protegido com nebulização com uma temperatura $60,4 \%$ superior à externa e o ambiente testemunha com 93,9\% acima da temperatura externa.

Apesar da temperatura do ar estar acima da ideal para as culturas, a umidade relativa do ar após a nebulização atingiu valores que segundo Cermeño (1994) estão na faixa de umidade relativa ótima para as principais espécies cultivadas em ambiente protegido. Assim, a nebulização nesse caso não atingiu valores de umidade relativa que poderiam propiciar maiores incidências de doenças. 


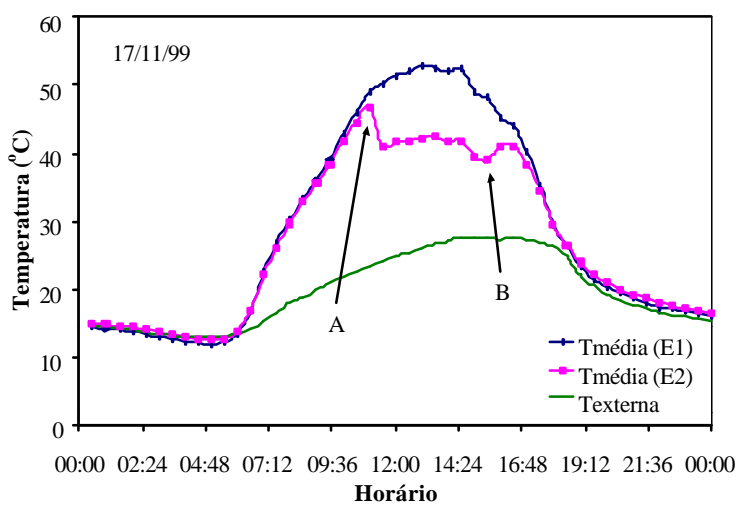

A - início da nebulização intermitente (11:00h)

B $\quad-$ final da nebulização (15:30h)

Figura 18. Variação da temperatura média do ar no ambiente protegido com acionamento do nebulizador (E2), no ambiente protegido testemunha (E1) e no ambiente externo, no dia 17/11/99.

\subsection{Variação vertical e horizontal de temperatura do ar.}

Na Figura 19a estão representados os perfis verticais de temperatura do ar no dia 07/11/99, no ambiente protegido onde houve nebulização com as cortinas laterais fechadas e na Figura 19b, os perfis verticais de temperatura no ambiente testemunha. As 8:30h, representa o horário anterior a nebulização, quando os dois ambientes protegidos apresentavam distribuição de temperatura do ar semelhante, com temperaturas variando de $32,0^{\circ} \mathrm{C}$ ao nível de $0,5 \mathrm{~m}$ e ao redor de $38,0^{\circ} \mathrm{C}$ ao nível de $4,0 \mathrm{~m}$.

O perfil vertical de temperatura do ar determinado às 9:00h, representa o momento anterior ao início da nebulização intermitente. Nesse horário, as temperaturas médias dos dois ambientes protegidos apresentam distribuição semelhantes, com temperaturas variando de cerca de $36,0^{\circ} \mathrm{C}$, ao nível de $0,5 \mathrm{~m}$, a $42,0^{\circ} \mathrm{C}$ ao nível de $4,0 \mathrm{~m}$. 

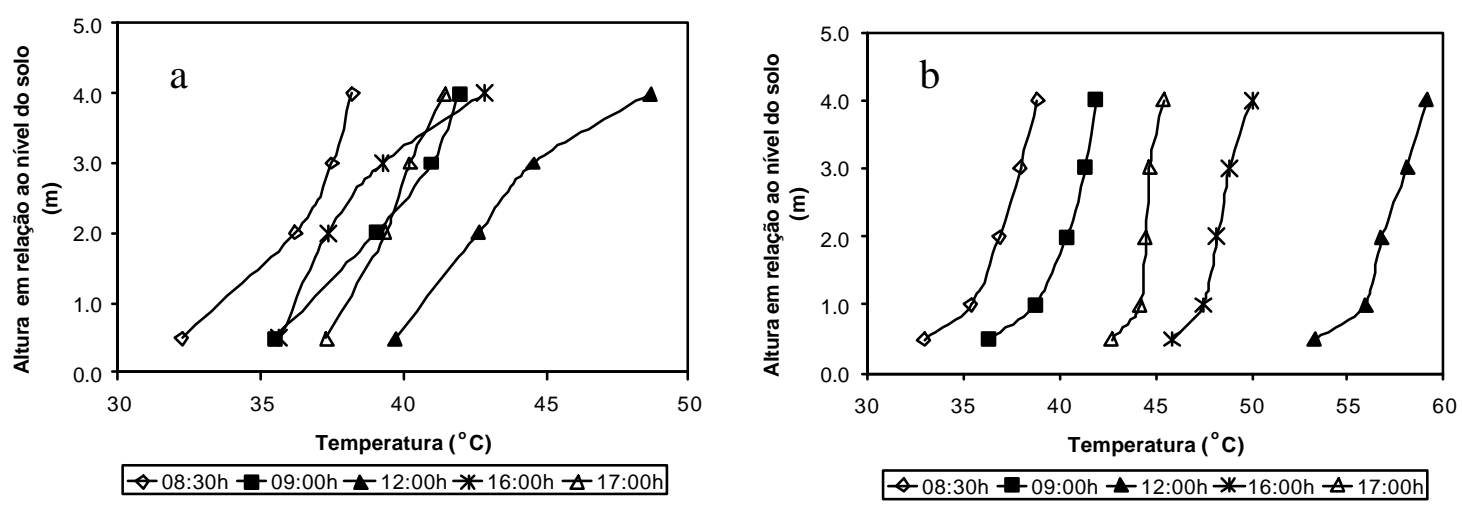

Figura 19. Perfil vertical de temperatura no ambiente protegido com cortinas fechadas e nebulização (a) e ambiente protegido controle (b). Início da nebulização (9:00h), durante a nebulização (12:00h), no final da nebulização (16:00h) e uma hora após o final da nebulização (17:00h), no dia 07/11/99.

No perfil determinado às 12:00h, Figura 19a, em comparação com a Figura 19b, observa-se a redução de temperatura do ar pela nebulização no ambiente protegido de cerca de $12,0^{\circ} \mathrm{C}$, ou seja, $21,4 \%$, com valores médios de temperatura do ar no perfil de $56,2^{\circ} \mathrm{C}$ no ambiente protegido controle e $44,2^{\circ} \mathrm{C}$ no ambiente com nebulização. No perfil das 16:00h observa-se a distribuição vertical de temperatura no momento final da nebulização. Este perfil segue a mesma tendência de distribuição do perfil das 12:00h com maior influência da nebulização na redução da temperatura do ar ao nível de 0,5 a 3,0m de altura em relação ao nível do solo, devido ao fato de que o sistema de nebulização estar instalado a 3,0m de altura. A 4,0m de altura, a redução de temperatura do ar às $12: 00 \mathrm{~h}$ foi de $10,0^{\circ} \mathrm{C}$ e a $0,5 \mathrm{~m}$ de $13,6^{\circ} \mathrm{C}$, enquanto que às $16: 00 \mathrm{~h}$, a redução de temperatura do ar foi de $10,2^{\circ} \mathrm{C}$ e $7,1^{\circ} \mathrm{C}$, respectivamente.

No perfil determinado às 17:00h, estão representadas as temperaturas do ar após o encerramento da nebulização. Nesse horário, a temperatura média do ar no perfil no ambiente protegido manejado variou de 37,3 a $41,5^{\circ} \mathrm{C}$, nos níveis de 0,5 a 4,0m de altura, enquanto que no ambiente protegido controle a temperatura média do ar variou de 42,7 a $45,4^{\circ} \mathrm{C}$, respectivamente. Mesmo após o encerramento da nebulização, houve redução na temperatura média do ar no perfil de $4,7^{\circ} \mathrm{C}$, com valores de temperatura 
média do perfil de $44,1^{\circ} \mathrm{C}$ para o ambiente protegido controle e $39,4^{\circ} \mathrm{C}$ para o ambiente protegido com nebulização.

$\mathrm{Na}$ Figura 20, estão representadas as isotermas a 0,5m de altura em relação ao nível do solo no dia 07/11/99 para o ambiente protegido com nebulização e cortinas laterais fechadas (20a, 20b, 20c e 20d) e o ambiente protegido testemunha (20e, 20f, 20g e 20h) para os horários de 9:00h (20a e 20e), 12:00h (20b e 20f), 16:00h (20c e 20g) e 17:00h (20d e 20h).
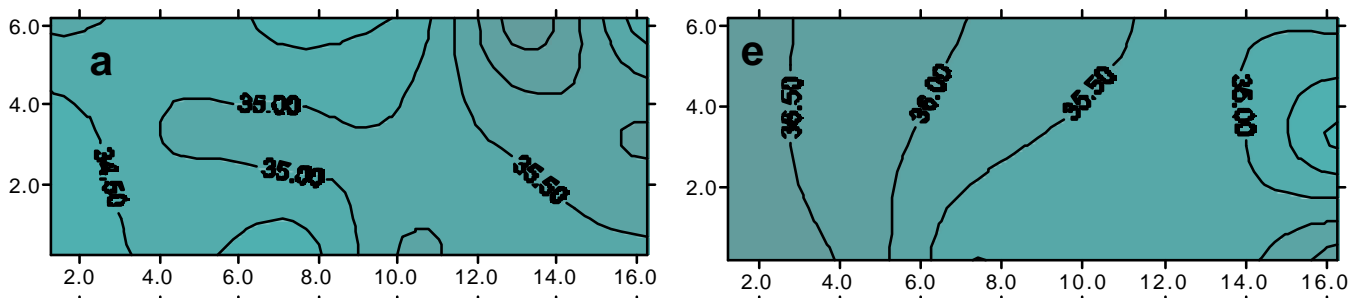

$\left({ }^{\circ} \mathrm{C}\right)$
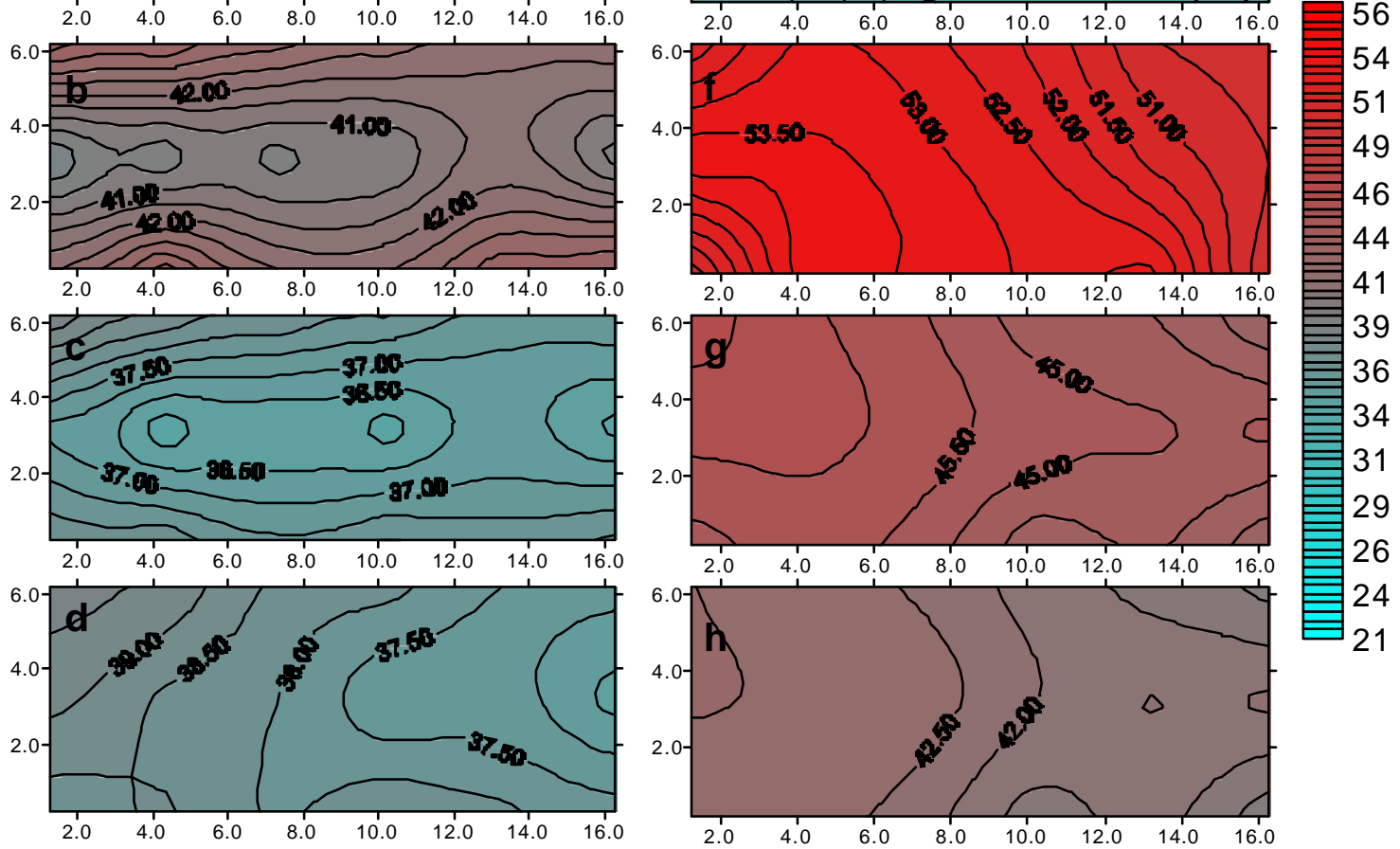

Figura 20. Distribuição de temperatura do ar no ambiente protegido com nebulização e cortinas laterais fechadas ( $\mathrm{a}, \mathrm{b}, \mathrm{c}$ e d) e no ambiente protegido controle (e, $\mathrm{f}$, g e h) para os horários de 9:00h (a e e), 12:00h (b e f), 16:00h (c e g), 17:00h (d e h) a 0,5m de altura no dia 07/11/99 O eixo x representa a largura (m) e y o comprimento do ambiente protegido (m). 
Às 9:00h, a variação de temperatura nos diferentes pontos de amostragem nos ambientes protegidos, foi de 1,5 a $2,0^{\circ} \mathrm{C}$, no ambiente protegido manejado e o ambiente protegido controle, respectivamente.

Observa-se nas isotermas das 12:00h (Figuras 20b e 20f), um período de grande elevação de temperatura do ar no ambiente protegido, onde o efeito da nebulização promoveu a redução de temperatura do ar. Enquanto no ambiente protegido controle (Figura 20f) as temperaturas médias no perfil atingiram $52,1^{\circ} \mathrm{C}$, no ambiente protegido nebulizado (Figura 20b), a temperatura do ar média reduziu para $42,2^{\circ} \mathrm{C}$, ou seja, $19,0 \%$. As temperaturas do ar no ambiente protegido nebulizado variaram de 40,5 a $43,5^{\circ} \mathrm{C}$, formando uma zona central de redução de temperatura do ar por efeito do alcance da névoa aspergida pelos nebulizadores. Já no ambiente protegido controle, a variação de temperatura do ar foi de 49,5 a cerca de $55,0^{\circ} \mathrm{C}$.

Às 16:00h, no ambiente protegido com nebulização (Figura 20c) comparado com o ambiente protegido controle (Figura 20g), a redução na temperatura média do ar foi de $7,8^{\circ} \mathrm{C}(17,2 \%)$, com temperatura do ar média do perfil de 37,5 e $45,3^{\circ} \mathrm{C}$, respectivamente. A temperatura do ar no ambiente protegido nebulizado, variou de 36,0 a $38,0^{\circ} \mathrm{C}$ formando também no centro uma zona de maior resfriamento, devido ao efeito da nebulização, enquanto que no ambiente protegido controle a temperatura do ar variou de 44,0 a $46,0^{\circ} \mathrm{C}$.

Às 17:00h, uma hora após o término da nebulização, o ambiente protegido controle estava com temperatura $4,4^{\circ} \mathrm{C}$ acima no ambiente protegido nebulizado, ou seja, com temperatura média do ar 11,6\% maior.

Na Figura 21, estão representadas as isotermas a 2,0m de altura no dia 07/11/99 para o ambiente protegido com nebulização e cortinas laterais fechadas (21a, 21b, 21c e 21d) e o ambiente protegido controle (21e, 21f, $21 \mathrm{~g}$ e 21h) para os horários de 9:00h (21a e 21e), 12:00h (21b e 21f), 16:00h (21c e 21g) e 17:00h (21d e 21h). 

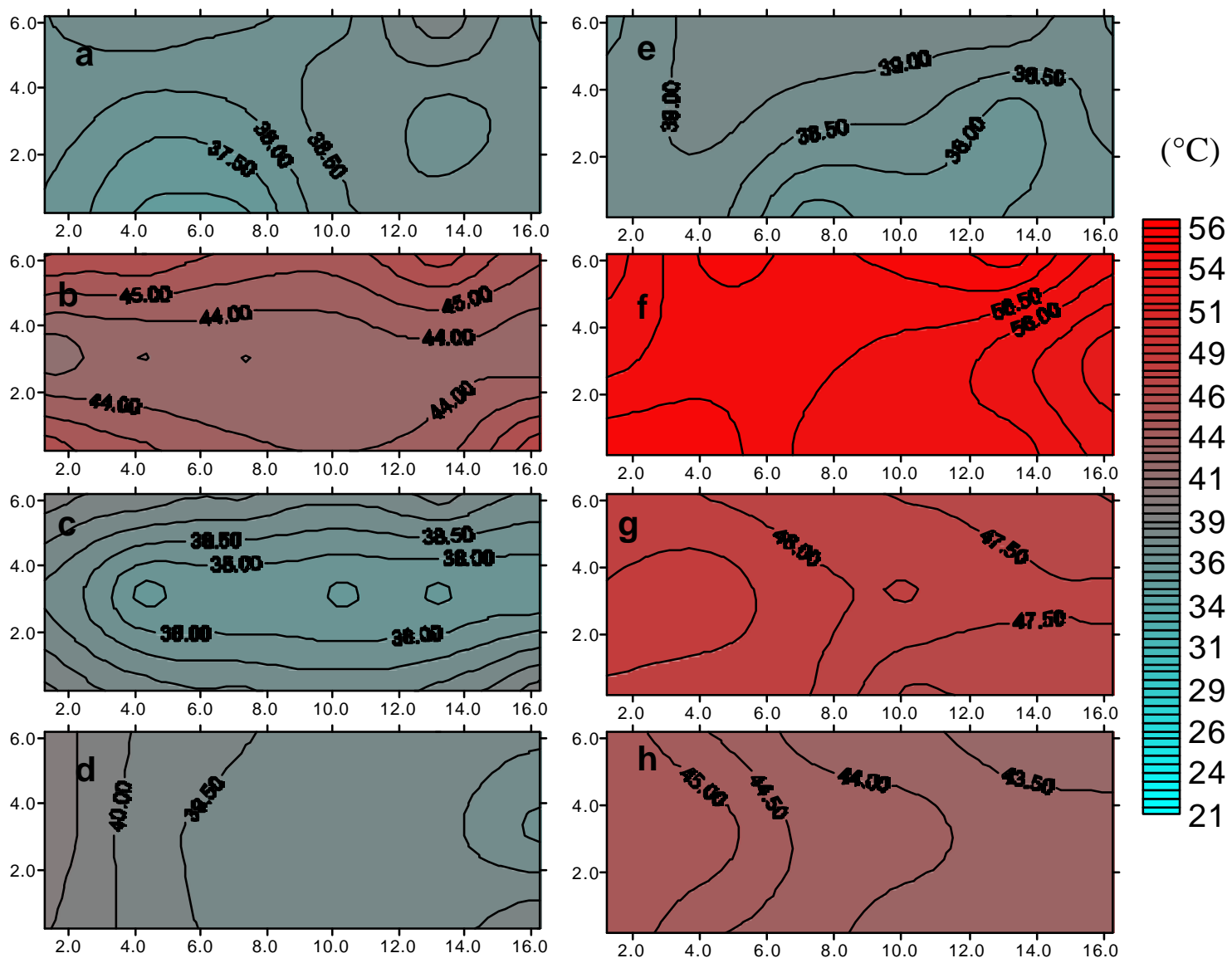

Figura 21. Distribuição de temperatura do ar no ambiente protegido com nebulização e cortinas laterais fechadas ( $a, b, c$ e d) e no ambiente protegido controle (e, $f$, g e h) para os horários de 9:00h (a e e), 12:00h (b e f), 16:00h (c e g), 17:00h (d e h) a 2,0m de altura no dia 07/11/99 O eixo x representa a largura (m) e y o comprimento do ambiente protegido (m).

A 2,0m de altura, a distribuição horizontal de temperatura média do ar nos ambientes protegidos seguiu a mesma tendência da ocorrida a $0,5 \mathrm{~m}$, porém com temperaturas mais elevadas, conforme pôde também ser observado na Figura 19 que representa o perfil de distribuição vertical de temperatura do ar no ambiente protegido durante determinados períodos do dia. As temperaturas do ar no ambiente protegido manejado, às 9:00h (Figura 21a), variaram de 37,0 a $39,0^{\circ} \mathrm{C}$, enquanto que no ambiente protegido controle variaram de 38,0 a $39,0^{\circ} \mathrm{C}$ (Figura 21e), com médias de temperatura do ar de 37,9 e $38,4^{\circ} \mathrm{C}$, respectivamente. As $12: 00 \mathrm{~h}$, a variação foi de 43,5 a $45,5^{\circ} \mathrm{C}$ no 
ambiente protegido com nebulização e de 55,0 a $57,0^{\circ} \mathrm{C}$ no ambiente protegido controle, com médias de 44,8 e $56,4^{\circ} \mathrm{C}$, respectivamente, reduzindo a temperatura em $20,6 \%$. Às 16:00h, a variação foi de 37,5 a $39,5^{\circ} \mathrm{C}$ no ambiente protegido com nebulização (Figura 21c) e de 47,5 a $48,5^{\circ} \mathrm{C}$ no ambiente protegido controle (Figura $21 \mathrm{~g}$ ), com médias de 38,8 e $47,8^{\circ} \mathrm{C}$, respectivamente, reduzindo a temperatura em 18,8\%. Nos horários em que houve nebulização, ocorreu a formação de zonas centrais no ambiente protegido com temperaturas do ar menores que nas laterais dos mesmos. Às 17:00h, mesmo após o encerramento da nebulização, houve efeito da redução de temperatura do ar. No ambiente protegido manejado as temperaturas do ar variaram de 39,0 a $40,5^{\circ} \mathrm{C}$ (Figura 21d) e no ambiente protegido controle de 43,5 a 45,0 ${ }^{\circ} \mathrm{C}$ (Figura 21h), com temperaturas médias de 39,6 e $44,2^{\circ} \mathrm{C}$, respectivamente.

Ambientes protegidos com as cortinas fechadas atingem valores de temperatura do ar a níveis acima dos ideais de temperatura da maioria das culturas. Somente a utilização do sistema de nebulização como sistema de resfriamento, não seria suficiente para manter uma condição ideal de desenvolvimento para as plantas. $O$ correto dimensionamento do sistema de nebulização proporcionaria melhor homogeneidade na distribuição de temperatura do ar, evitando a formação de zonas de maior resfriamento e zonas de maior aquecimento como ocorreu com as laterais do ambiente protegido. A maior redução de temperatura do ar na zona central do ambiente protegido provavelmente foi devida a sobreposição da névoa aspergida pelos nebulizadores.

\subsubsection{Cortinas laterais abertas}

\subsection{Distribuição temporal de temperatura do ar}

O efeito do nebulizador sobre a redução da temperatura do ar no ambiente protegido com as cortinas abertas, pode ser observado nas Figuras 22 e 23, onde as cortinas dos ambientes permaneceram abertas desde o dia anterior e a temperatura do ar no ambiente protegido se encontrava em equilíbrio com a externa. As cortinas foram mantidas abertas a $2,5 \mathrm{~m}$ de altura. 
No ambiente protegido (E1), onde foi utilizado a nebulização no dia 02/11/99 (Figura 22), às 9:00h iniciou-se a nebulização intermitente com 15 minutos de funcionamento e 15 minutos sem nebulização e assim sucessivamente até o final da nebulização às 15:30h. Observou-se que mesmo após a interrupção da nebulização, a evaporação influenciou na redução da temperatura do ar no ambiente (Figuras 22 e 23). As reduções na temperatura do ar proporcionadas pela nebulização no ambiente protegido manejado em relação ao ambiente protegido controle nos dias 2 e 3/11/99 foram significativas a $1,0 \%$ de probabilidade pelo teste $\mathrm{t}$.

$\mathrm{O}$ aumento da umidade relativa do ar ocasionada pela nebulização no ambiente (E1) em relação ao ambiente controle foi de 51,1\%. O ambiente controle apresentou, para este dia, uma umidade relativa do ar média durante o período de acionamento do nebulizador de 36,1\%, enquanto que no ambiente onde houve nebulização (E1), a umidade relativa do ar média foi de 55,1\%. De acordo com Cermeño (1994) esse valor de umidade relativa, mesmo com nebulização, estaria no limite inferior do valor de umidade relativa ótima indicada para as culturas do tomate, pimentão e abaixo para maioria das culturas em ambiente protegido. Porém, como a umidade relativa está inversamente relacionada com a temperatura do ar, maiores valores de umidade relativa do ar poderão ser encontradas a noite ou nas primeiras horas da manhã quando a temperatura do ar diminui. Pezzopane et al. (1995), Farias et al. (1993) e Folegatti et al. (1997) encontraram maiores valores de umidade relativa no interior do ambiente protegido que em ambiente externo, principalmente nas primeiras horas da manhã. Assim, o manejo correto das cortinas laterais é importante para se garantir a renovação do ar, evitar o acúmulo de vapor de água no interior do ambiente protegido e a condensação de água na cobertura plástica e gotejo sobre as plantas.

A temperatura média do ar no ambiente protegido durante o período em que o ambiente foi nebulizado foi de $28,4^{\circ} \mathrm{C}$, enquanto que, a temperatura do ar no ambiente controle nesse mesmo período foi $32,7^{\circ} \mathrm{C}$. Houve uma redução de temperatura do ar da ordem de $4,3^{\circ} \mathrm{C}$, que representou uma redução de $13,1 \%$ em relação ao ambiente controle. A temperatura do ar externa do ar média para este período foi de $27,1^{\circ} \mathrm{C}$, próxima a temperatura do ar no ambiente protegido resfriado por nebulização. $\mathrm{O}$ 
ambiente controle ficou com temperatura média do ar, naquele período, 20,4\% superior à temperatura do ar externa, enquanto que o ambiente nebulizado ficou com temperatura média do ar 4,6\% superior à externa.

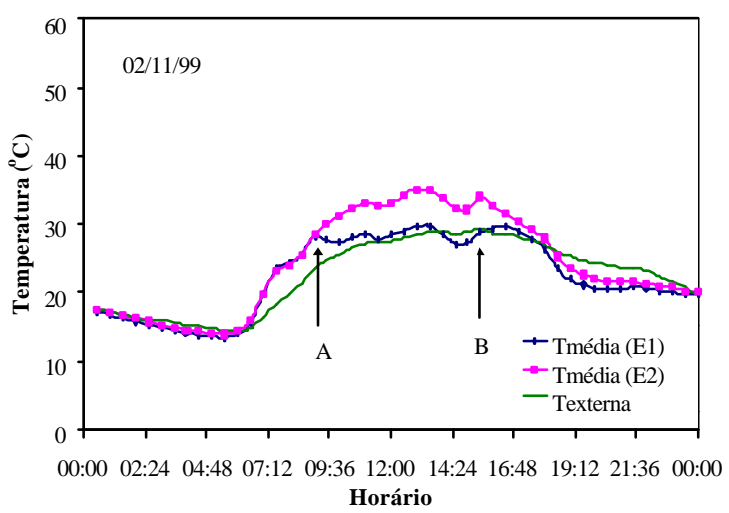

A - início da nebulização intermitente (9:00h)

B $\quad-$ final da nebulização (15:30h)

Figura 22. Variação da temperatura média do ar no ambiente protegido com acionamento do nebulizador e cortinas abertas (E1), no ambiente protegido controle com cortinas abertas (E2) e no ambiente externo, no dia 02/11/99.

No dia 03/11/99, observou-se resultados muito semelhantes (Figura 23). Nesse dia, o nebulizador foi acionado às 9:15h e desligado às 15:30h. As cortinas laterais dos ambientes protegidos foram fechadas às 17:00h.

A umidade relativa do ar média no ambiente, correspondente ao período em que o nebulizador esteve em funcionamento, foi de $55,3 \%$ e a umidade relativa do ar média no ambiente controle, durante este mesmo período, foi de 33,9\%. O acréscimo na umidade relativa do ar média para este período foi de $63,3 \%$.

A temperatura média do ar no ambiente protegido nebulizado durante o período de acionamento do sistema foi de $29,2^{\circ} \mathrm{C}$, enquanto que a temperatura média do ar no ambiente controle no período considerado foi de $34,5^{\circ} \mathrm{C}$ e a temperatura do ar externa, $29,4^{\circ} \mathrm{C}$. A temperatura média do ar no ambiente protegido com nebulização ficou $5,3^{\circ} \mathrm{C}$ abaixo da temperatura do ar no ambiente controle, ou seja, 15,3\% menor. 


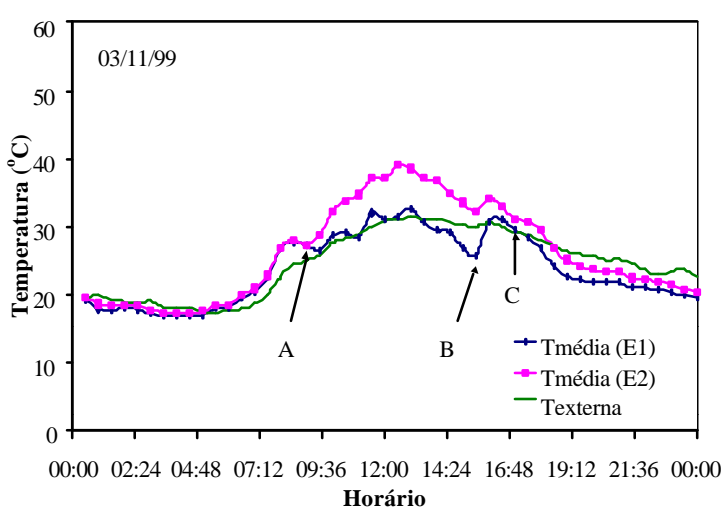

A - início da

nebulização

intermitente (9:15h)

B - final da nebulização (15:30h)

$\mathrm{C}-$ cortinas laterais fechadas (17:00h)

Figura 23. Variação da temperatura média do ar no ambiente protegido com acionamento do nebulizador e cortinas abertas (E1), no ambiente protegido controle com cortinas abertas (E2) e no ambiente externo, no dia 03/11/99.

A nebulização em ambiente protegido bem ventilado proporcionou redução na temperatura do ar a níveis próximos à temperatura do ar externa. Das observações dos resultados obtidos nos dias 2 e 3/11/99 pode-se inferir que o período de nebulização pode ser reduzido, desde que o manejo das cortinas seja adequado.

\subsection{Variação vertical e horizontal de temperatura do ar.}

$\mathrm{Na}$ Figura 24a estão representados os perfis de distribuição vertical de temperatura do ar no dia 03/11/99 no ambiente protegido onde houve nebulização com as cortinas laterais abertas a 2,5m de altura e a Figura $24 \mathrm{~b}$ apresenta o perfil vertical de temperatura do ar no ambiente protegido com cortinas abertas a 2,5m de altura, porém, sem nebulização (testemunha).

O perfil vertical de temperatura do ar determinado às 9:00h, representa o momento anterior ao início da nebulização intermitente. Nesse horário, as temperaturas médias do ar dos ambientes protegidos apresentavam condições de distribuição de temperatura do ar semelhantes, com temperaturas do ar variando de cerca de $26,5^{\circ} \mathrm{C}$ ao nível de $0,5 \mathrm{~m}$ de altura e ao redor de $27,5^{\circ} \mathrm{C}$ ao nível de $4,0 \mathrm{~m}$. 

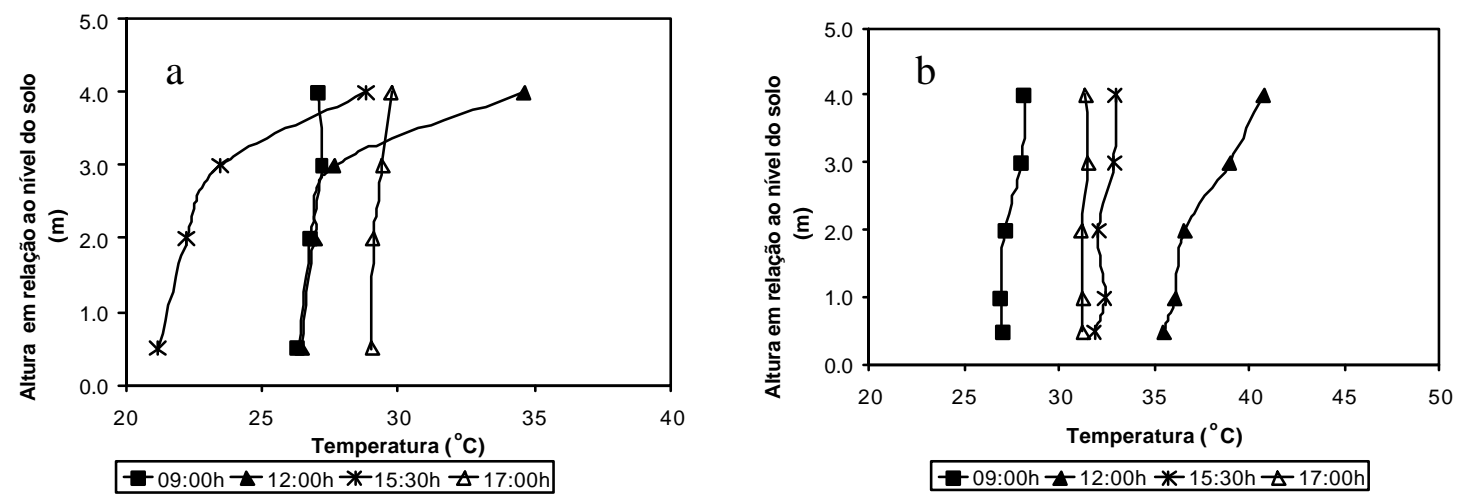

Figura 24. Perfil vertical de temperatura do ar no ambiente protegido com cortinas fechadas e nebulização (a) e ambiente protegido testemunha (b), no início da nebulização (9:00h), durante a nebulização (12:00h), no final da nebulização (16:00h) e uma hora após o final da nebulização (17:00h), no dia 03/11/99.

Às 12:00h houve redução de temperatura do ar pela nebulização no ambiente protegido, comparado com o ambiente controle, de cerca de $7,6^{\circ} \mathrm{C}$, ou seja, $19,9 \%$, com valores médios de temperatura do ar no perfil de $38,1^{\circ} \mathrm{C}$ no ambiente protegido testemunha e $30,5^{\circ} \mathrm{C}$ no ambiente com nebulização. O perfil das 15:30h (Figura 24a e 24b) representa a distribuição vertical de temperatura do ar no momento final da nebulização. Houve redução média de temperatura do ar no perfil de $7,4^{\circ} \mathrm{C}$, ou $22,8 \%$, com temperaturas médias do ar do perfil de 25,0 e $32,4^{\circ} \mathrm{C}$, para o ambiente protegido com nebulização e controle, respectivamente. Este perfil segue a mesma tendência de distribuição que o perfil das 12:00h com maior influência da nebulização na redução da temperatura do ar de 0,5 a 3,0m de altura. Com as cortinas laterais abertas, houve maior aquecimento do ar a 4,0m de altura em relação ao nível do solo. A 4,0m de altura, a redução de temperatura do ar às $12: 00 \mathrm{~h}$ foi de cerca de $6,1^{\circ} \mathrm{C}$ e a $0,5 \mathrm{~m}$ de altura foi de $9,1^{\circ} \mathrm{C}$, enquanto que às $15: 30 \mathrm{~h}$, a redução de temperatura do ar foi de $4,1^{\circ} \mathrm{C}$ e $10,6^{\circ} \mathrm{C}$, respectivamente.

O perfil das 17:00h (Figura 24a e 24b) representa o período após o encerramento da nebulização. Nesse horário, a temperatura média do ar no perfil no ambiente protegido com nebulização variou de 29,0 a $29,7^{\circ} \mathrm{C}$, de 0,5 a $4,0 \mathrm{~m}$ de altura, enquanto que no ambiente protegido controle a temperatura média do ar variou de 31,2 a 
$31,3^{\circ} \mathrm{C}$, respectivamente. Nesse perfil vertical, não houve variação de temperatura do ar. Mesmo após o encerramento da nebulização, houve redução na temperatura média do ar no perfil de $1,9^{\circ} \mathrm{C}$, com valores de temperatura média do ar no perfil de $29,4^{\circ} \mathrm{C}$ para o ambiente protegido controle e $31,3{ }^{\circ} \mathrm{C}$ para o ambiente protegido com nebulização.

$\mathrm{Na}$ Figura 25, estão representadas as isotermas a 0,5m de altura no dia 03/11/99 para o ambiente protegido com nebulização e cortinas laterais abertas a 2,5m de altura em relação ao nível do solo (25a, 25b, 25c e 25d) e no ambiente protegido testemunha (25e, 25f, 25g e 25h) para os horários de 9:00h (25a e 25e), 12:00h (25b e 25f), 15:30h (25c e $25 \mathrm{~g})$ e $17: 00 \mathrm{~h}(25 \mathrm{~d}$ e $25 \mathrm{~h})$.

Às 9:00h, a variação de temperatura do ar nos diferentes pontos de amostragem nos ambientes protegidos, foi de 26,5 a $27,0^{\circ} \mathrm{C}$ nos ambientes protegidos, com temperaturas do ar médias de 26,6 e $26,9^{\circ} \mathrm{C}$ para o ambiente protegido nebulizado e o ambiente protegido controle, respectivamente (Figuras 25a e 25e).

Analisando-se a Figura 25b, às 12:00h, observou-se elevação de temperatura do ar na face norte do ambiente protegido. Da região central do ambiente protegido ao lado sul, onde ocorreu o efeito da nebulização e ventilação natural, houve maior redução de temperatura do ar. Enquanto que no ambiente protegido controle (Figura 25f) as temperaturas médias do ar no perfil foram de $35,3^{\circ} \mathrm{C}$, o ambiente protegido nebulizado (Figura 25b), teve sua temperatura do ar média reduzida a $28,8^{\circ} \mathrm{C}$, ou seja, $18,4 \%$. A temperatura do ar no ambiente protegido nebulizado variou de 26,0 a $32,0^{\circ} \mathrm{C}$, apresentando uma região central onde a redução de temperatura do ar por efeito da nebulização foi mais pronunciada. No ambiente protegido controle, a variação de temperatura do ar foi de 34,0 a $35,5^{\circ} \mathrm{C}$. Às $15: 30 \mathrm{~h}$, no ambiente protegido com nebulização (Figura 25c) comparado com o ambiente protegido controle (Figura 25g), a redução na temperatura média do ar foi de $8,8^{\circ} \mathrm{C}$ (27,9\% de redução), com temperatura do ar média de 22,7 e $31,5^{\circ} \mathrm{C}$, respectivamente. A temperatura do ar no ambiente protegido nebulizado, variou de 21,5 a $23,5^{\circ} \mathrm{C}$ formando no centro uma região de maior resfriamento, devido o efeito da nebulização, enquanto que no ambiente protegido controle a distribuição de temperatura do ar oscilou de 31,0 a $32,0^{\circ} \mathrm{C}$. 

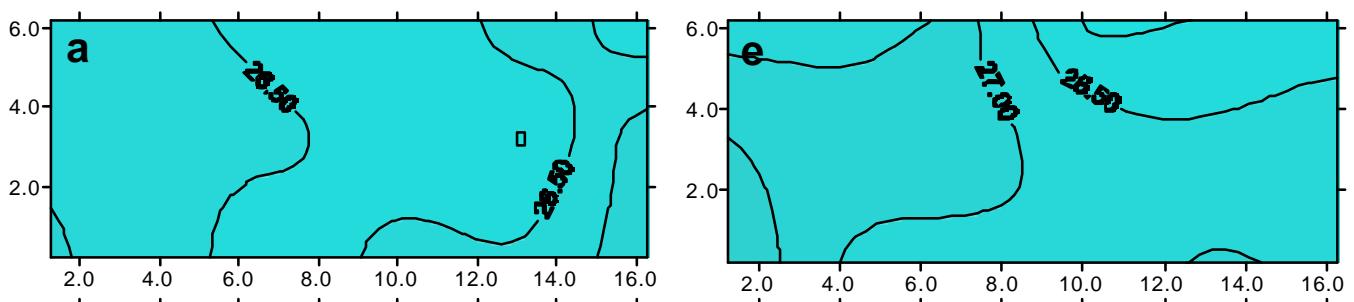

$\left({ }^{\circ} \mathrm{C}\right)$
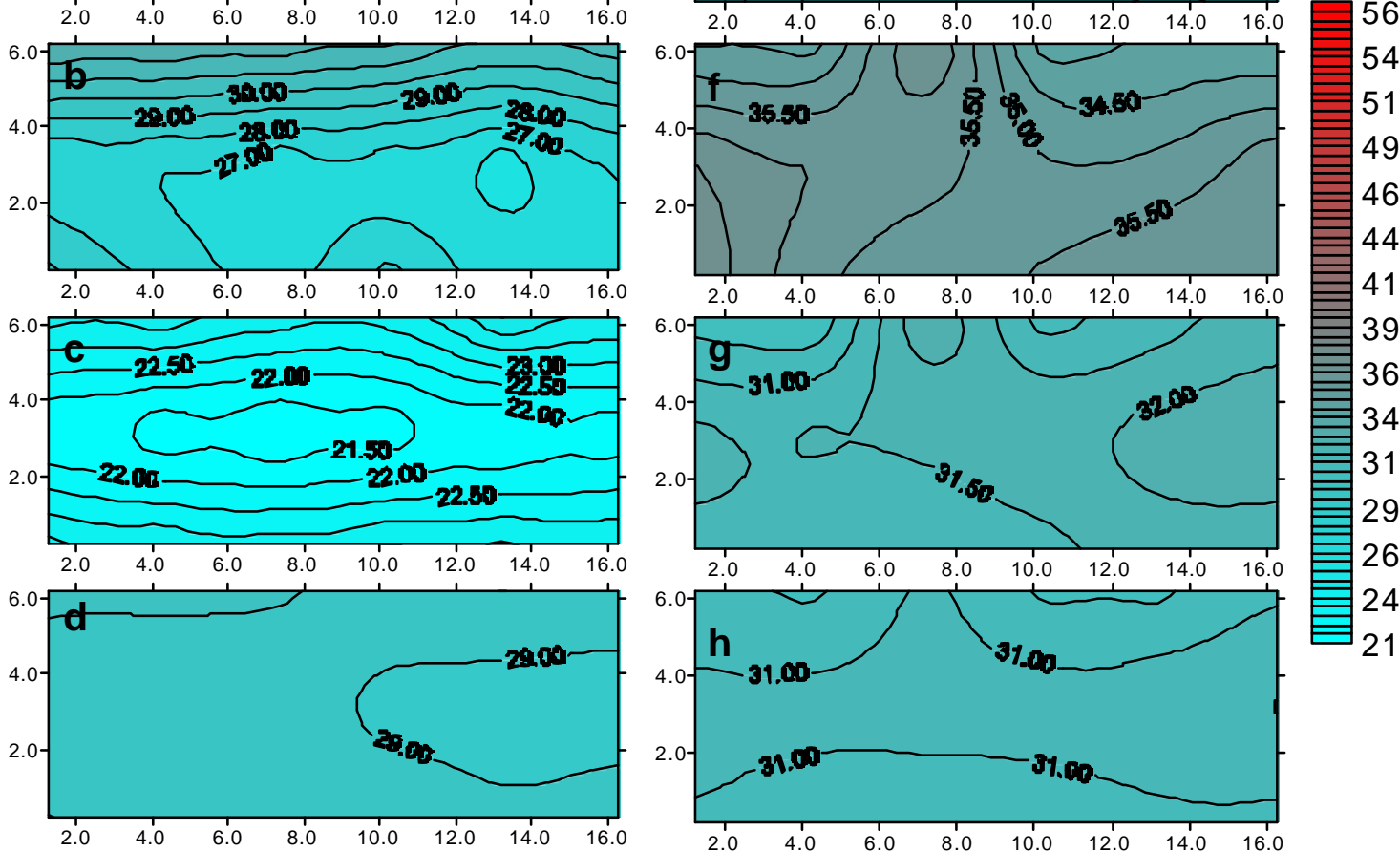

Figura 25. Distribuição de temperatura do no ambiente protegido com nebulização e cortinas laterais abertas a 2,5m de altura em relação ao nível do solo (a, b, c e d) e no ambiente protegido controle (e, f, g e h) para os horários de 9:00h (a e e), 12:00h (b e f), 15:30h (c e g), 17:00h (d e h) a 0,5m de altura dia 03/11/99. O eixo x representa a largura (m) e y o comprimento do ambiente protegido (m).

Às 17:00h, após o término da nebulização no ambiente protegido controle a temperatura do ar estava $1,6^{\circ} \mathrm{C}$ acima da temperatura do ar no ambiente protegido com nebulização. As temperaturas médias do ar no perfil horizontal a $0,5 \mathrm{~m}$ de altura no ambiente protegido nebulizado foi de $29,3^{\circ} \mathrm{C}$ e no ambiente protegido testemunha foi de $30,9^{\circ} \mathrm{C}$. A distribuição de temperatura do ar no ambiente protegido foi bastante homogênea. 
$\mathrm{Na}$ Figura 26, estão representadas as isotermas a 2,0m de altura em relação ao nível do solo no dia 03/11/99 para o ambiente protegido com nebulização e cortinas laterais abertas a 2,5m de altura em relação ao nível do solo (26a, 26b, 26c e 26d) e o ambiente protegido testemunha (26e, 26f, 26g e 26h) para os horários de 9:00h (26a e 26e), 12:00h (26b e 26f), 15:30h (26c e 26g) e 17:00h (26d e 26h).
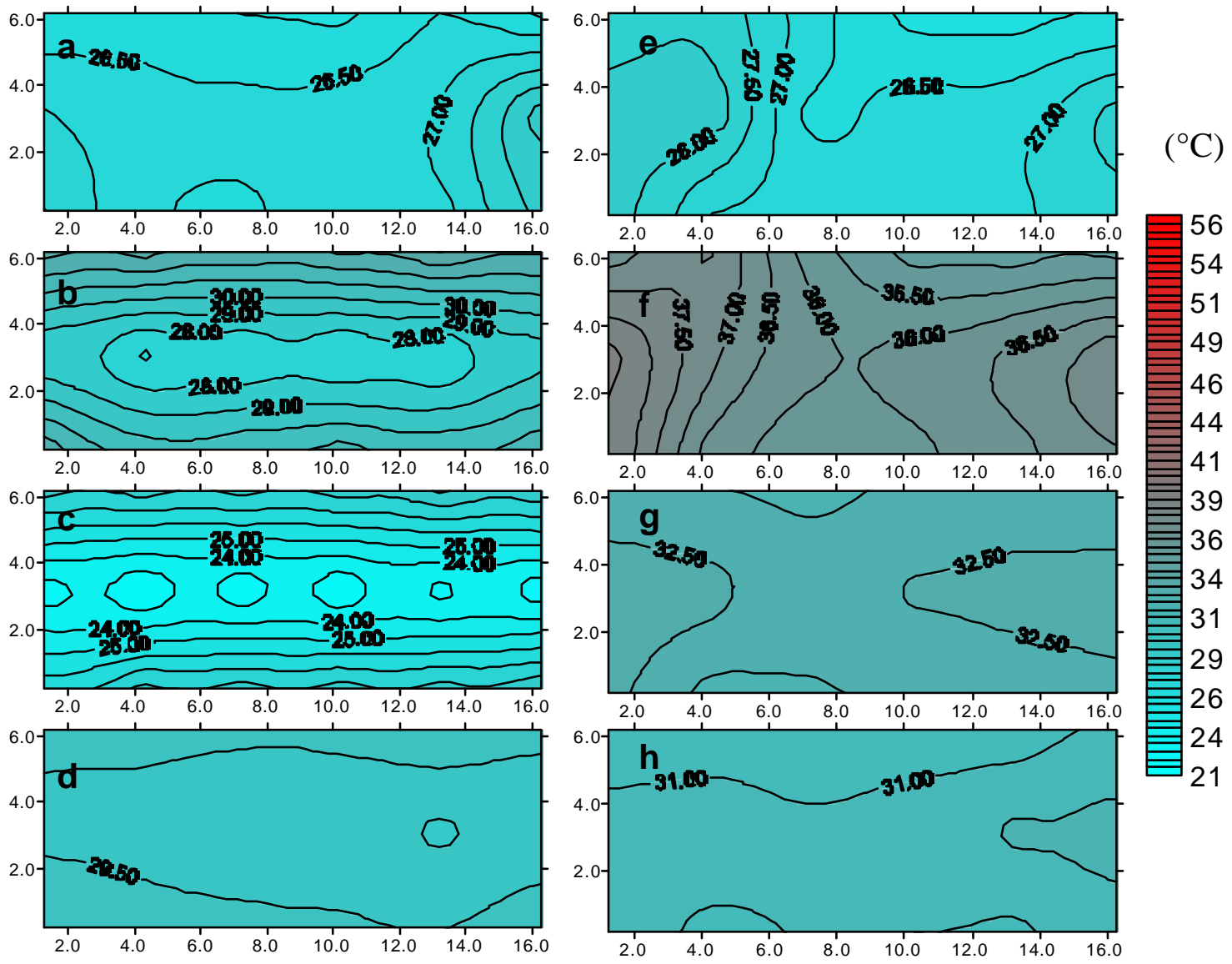

Figura 26. Distribuição de temperatura do ar no ambiente protegido com nebulização e cortinas laterais abertas a 2,5m de altura em relação ao nível do solo (a, b, c e d) e no ambiente protegido controle (e, f, g e h) para os horários de 9:00h (a e e), 12:00h (b e f), 15:30h (c e g), 17:00h (d e h) a 2,0m de altura no dia 03/11/99. O eixo x representa a largura $(\mathrm{m})$ e y o comprimento do ambiente protegido (m). 
A 2,0m de altura a distribuição horizontal de temperatura média do ar nos ambientes protegidos seguiu a mesma tendência da ocorrida a $0,5 \mathrm{~m}$, porém com temperaturas do ar mais elevadas, conforme pôde também ser observado na Figura 24 que representa o perfil de distribuição vertical de temperatura do ar no ambiente protegido durante o dia. As temperaturas do ar no ambiente protegido com nebulização e cortinas laterais abertas às 9:00h (Figura 26a) e no ambiente protegido controle (Figura 26e) variaram de 26,0 a $28,0^{\circ} \mathrm{C}$, com médias de temperatura do ar de 26,8 e $27,0^{\circ} \mathrm{C}$, respectivamente. Às 12:00h, a variação foi de 27,0 a $32,0^{\circ} \mathrm{C}$ no ambiente protegido com nebulização (Figura 26b) e de 35,0 a $38,0^{\circ} \mathrm{C}$ no ambiente protegido controle (Figura 26f), com médias de 30,7 e $36,4^{\circ} \mathrm{C}$, respectivamente, reduzindo a temperatura do ar em 15,7\%. Às 15:30h, a variação da temperatura do ar foi de 23,0 a $27,0^{\circ} \mathrm{C}$ no ambiente protegido com nebulização (Figura 26c) e de 32,0 a $32,5^{\circ} \mathrm{C}$ no ambiente protegido controle (Figura 26g), com médias de 26,4 e $32,1^{\circ} \mathrm{C}$, respectivamente, reduzindo a temperatura do ar em 17,8\%. Nos horários em que houve nebulização, da mesma forma como ocorreu a 0,5m de altura em relação ao nível do solo, ocorreu a formação de áreas centrais com temperaturas do ar menores que nas laterais do ambiente protegido. Às 17:00h, mesmo após o encerramento da nebulização, houve efeito da redução de temperatura do ar. No ambiente com nebulização as temperaturas do ar variaram de 29,0 a $29,5^{\circ} \mathrm{C}$ (Figura $26 \mathrm{~d}$ ) e no ambiente protegido controle de 31,0 a $31,5^{\circ} \mathrm{C}$ (Figura 26h), com temperaturas médias do ar de 29,5 e $31,0^{\circ} \mathrm{C}$, respectivamente (4,8\% inferior).

Com a combinação de diferentes sistemas de resfriamento pode-se alcançar um clima favorável às culturas durante os meses mais quentes. A nebulização combinada com boa ventilação do ambiente protegido proporcionou as maiores reduções na temperatura do ar. 
4.2.3. Efeito da abertura das cortinas e da nebulização na redução da temperatura do ar nos ambientes protegidos.

\subsubsection{Cortinas laterais abertas a 1,0m de altura em relação ao nível do solo.}

\subsection{Variação da temperatura do ar}

A Figura 27 representa a redução da temperatura média do ar no ambiente protegido (E1) onde as cortinas ficaram abertas a 1,0m de altura em relação ao nível do solo em comparação com o ambiente testemunha com cortinas fechadas (E2) para o dia 04/11/99. As cortinas laterais foram abertas e o sistema de nebulização foi acionado às 9:00h e às 15:00h foram fechadas as cortinas e desligado o nebulizador. A redução da temperatura do ar no ambiente protegido manejado em comparação com o ambiente controle foi significativa a 1,0\% de probabilidade pelo teste t. A temperatura média do ar nesse intervalo foi de $47,1^{\circ} \mathrm{C}$ para o ambiente testemunha (E2) e de $33,1^{\circ} \mathrm{C}$ para o ambiente com as cortinas abertas e nebulizado, diferença de $14,0^{\circ} \mathrm{C}$, que representou redução na temperatura média do ar de 29,7\%, em relação ao ambiente controle. A temperatura média do ar externa para esse intervalo foi de $30,8^{\circ} \mathrm{C}$, ficando o ambiente protegido com cortinas abertas e nebulização com temperatura do ar de 7,6\% superior a do ar externa e o ambiente testemunha com 52,9\% acima da temperatura do ar externa. A umidade relativa do ar média no ambiente correspondente ao período em que o nebulizador esteve em funcionamento foi de $54,3 \%$, e a umidade relativa do ar média no ambiente controle durante este mesmo período foi de 32,1\%. O acréscimo na umidade relativa do ar média para este período foi de $69,3 \%$.

A variação da temperatura média do ar nos ambientes protegidos com cortinas abertas e nebulização e o ambiente protegido controle no dia 01/12/99 está representada na Figura 28. A cortina zenital foi aberta às 10:45h. Às 12:00h, as cortinas laterais do ambiente E2 foram abertas a 1,0m de altura em relação ao nível do solo. O acionamento do nebulizador iniciou-se às $12: 45 \mathrm{~h}$ e o seu desligamento às $14: 30 \mathrm{~h}$. A redução da temperatura do ar no ambiente protegido manejado em comparação com o ambiente controle foi significativa a $1,0 \%$ de probabilidade pelo teste $t$. 


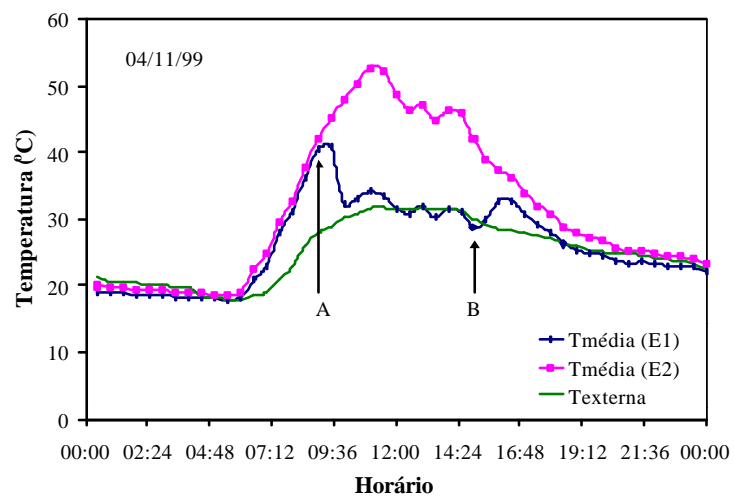

A - cortinas laterais abertas a 1,0m de altura em relação ao nível do solo e início da nebulização (9:00hs)

B - cortinas laterais fechadas e final da nebulização (15:00hs)

Figura 27. Variação da temperatura média do ar no ambiente protegido com nebulização e cortinas abertas a 1,0m de altura em relação ao nível do solo (E1), no ambiente protegido controle (E2) e no ambiente externo, no dia 04/11/99.

A temperatura média do ar no ambiente protegido controle durante o manejo foi de $48,2^{\circ} \mathrm{C}$ e a temperatura média do ar para o ambiente protegido com cortinas abertas e nebulização foi de $36,8^{\circ} \mathrm{C}$, mostrando uma redução na temperatura do ar de $11,3^{\circ} \mathrm{C}$ (23,6\% de redução). Entretanto, a temperatura do ar externa nesse período foi de $29,6^{\circ} \mathrm{C}$, representando um aumento da temperatura do ar no ambiente controle em relação à temperatura do ar média externa de $62,5 \%$ e uma elevação da temperatura do ar no ambiente com cortinas abertas e nebulização em relação à temperatura do ar externa de $24,2 \%$. Porém, considerando-se apenas o período de nebulização, observou-se uma temperatura média do ar no ambiente protegido controle de $45,1^{\circ} \mathrm{C}, 32,2^{\circ} \mathrm{C}$ no ambiente protegido com as cortinas abertas e nebulização e $30,5^{\circ} \mathrm{C}$ no ambiente externo. Assim, ocorreu redução de $12,9^{\circ} \mathrm{C}$ entre as temperaturas médias dos dois ambientes $(28,5 \%)$. A elevação na temperatura média do ar no ambiente protegido com nebulização em relação à temperatura do ar externa foi de 5,5\% e a elevação da temperatura do ar média no ambiente controle de 47,6\% em relação ao ambiente externo.

A umidade relativa do ar média no ambiente protegido controle foi de $49,9 \%$ e no ambiente protegido com cortinas abertas e nebulização foi de 43,8\%. A redução da umidade relativa do ar no ambiente protegido foi de 12,3\%. Com a abertura das cortinas laterais e zenitais no ambiente (E2) ocorreu redução da umidade relativa do ar pela troca 
de vapor d'água com o ambiente externo. Com a nebulização, posteriormente houve nova adição de água (vapor) no ambiente, voltando a elevar a umidade relativa (Figura 29).

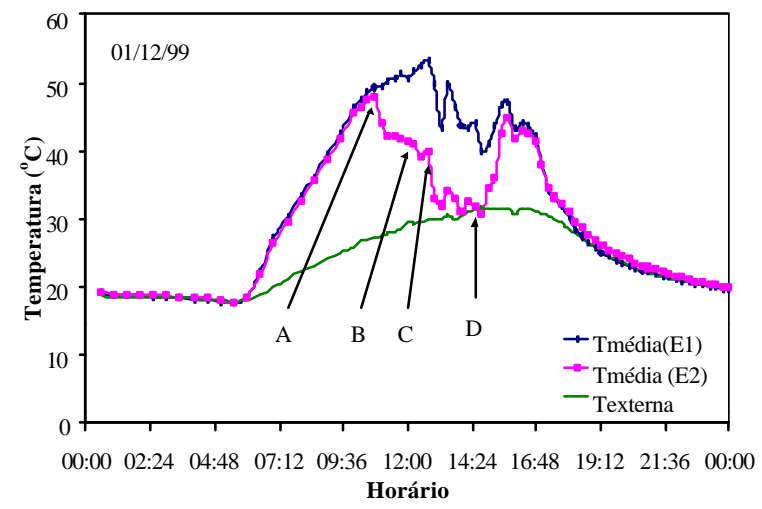

A - abertura da cortina zenital (10:45h)

B - cortinas laterais abertas a $1,0 \mathrm{~m}$ de altura em relação ao nível do solo (12:00h)

C - início da nebulização $(12: 45 h)$

D - final da nebulização $(14: 30 \mathrm{~h})$

Figura 28. Variação da temperatura média do ar no ambiente protegido com nebulização e cortinas abertas a 1,0m de altura em relação ao nível do solo (E2), no ambiente protegido controle (E1) e no ambiente externo, no dia 01/12/99.

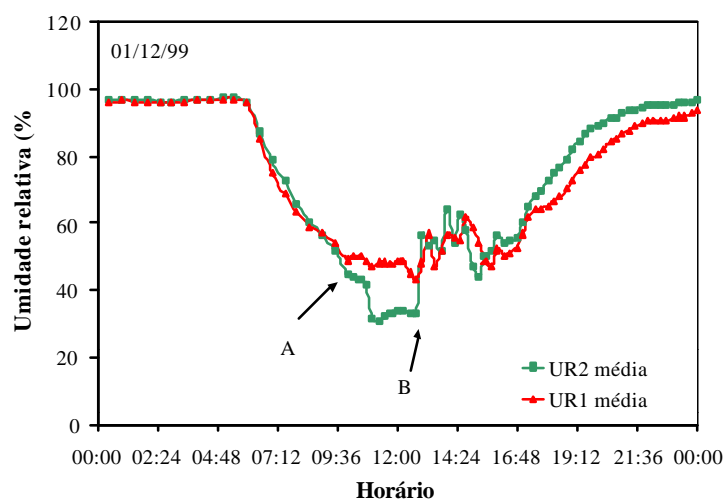

A - abertura da cortina zenital (10:45h) e abertura das cortinas laterais a $1,0 \mathrm{~m}$ de altura em relação ao nível do solo (12:00h)

B - início da nebulização (12:45h)

Figura 29. Variação temporal da umidade relativa do ar média no ambiente protegido com cortinas abertas e nebulização (UR2média) e ambiente controle (UR1média) durante o dia 01/12/99.

O manejo combinado de abertura de cortinas e nebulização apresentou-se como mais eficiente na redução da temperatura do ar em ambientes protegidos. A nebulização reduziu a temperatura do ar até ficar inferior a temperatura do ar externa, conforme citado Montero \& Antón (1994). Nas Figuras 27 e 28, observou-se o efeito da 
nebulização na redução da temperatura do ar, no dia 01/12/99, onde a temperatura do ar no ambiente protegido com cortinas abertas e nebulização se equiparou à temperatura do ar externa após o início da nebulização. O uso de um método de redução da temperatura do ar em ambientes protegidos pode não ser suficiente para reduzir a temperatura do ar a um nível aceitável pelas culturas em períodos de elevadas temperaturas. A combinação dos métodos permitiu uma redução da temperatura do ar mais eficiente.

\subsection{Variação vertical e horizontal de temperatura do ar.}

No dia 04/11/99, no ambiente protegido (E1), as cortinas laterais foram abertas a 1,0m de altura e acionado o sistema de nebulização às 9:00h. Às 15:00h, foram fechadas as cortinas e desligado o nebulizador.

Na Figura 30a estão representados os perfis de distribuição de temperatura do ar no dia 04/11/99, no ambiente protegido onde houve abertura de cortinas laterais a 1,0m de altura e nebulização e na Figura 30b estão representados os perfis de temperatura do ar no ambiente protegido controle. Às 9:00h, representa o horário anterior ao manejo das cortinas e nebulização, quando os dois ambientes protegidos apresentaram condições de distribuição de temperatura do ar muito semelhantes, com temperaturas do ar próximas a $40,0^{\circ} \mathrm{C}$ a $0,5 \mathrm{~m}$ de altura e ao redor de $44,0^{\circ} \mathrm{C}$ a $4,0 \mathrm{~m}$. No perfil determinado às $12: 30 \mathrm{~h}$, na Figura $30 \mathrm{a} \mathrm{em}$ comparação com a Figura 30b, observou-se o efeito da redução de temperatura do ar pela nebulização e ventilação natural. Nesse horário as cortinas foram abertas e a nebulização foi acionada, reduzindo a temperatura média do ar no ambiente em $17,0^{\circ} \mathrm{C}$, com valores médios de temperatura do ar no perfil de $47,2^{\circ} \mathrm{C}$ no ambiente protegido testemunha e $29,8^{\circ} \mathrm{C}$ no ambiente com nebulização e ventilação natural. $\mathrm{O}$ perfil das 17:00h representa o período após o encerramento da nebulização e o fechamento das cortinas. Nesse horário, ocorreu distribuição homogênea de temperatura do ar em todo o perfil, porém com valores médios de $30,5^{\circ} \mathrm{C}$ no ambiente protegido onde houve nebulização e ventilação natural e $34,0^{\circ} \mathrm{C}$ no ambiente controle, evidenciando o efeito de redução de temperatura do ar pela nebulização mesmo após o seu encerramento. Nesta hora do dia, o aquecimento da cobertura plástica pela radiação solar e a transmissão de calor através dessa para o ar do 
ambiente protegido, passou a ser pequena, não interferindo na temperatura do ar e não causando gradiente de temperatura, como ocorreu nos períodos mais quentes do dia.
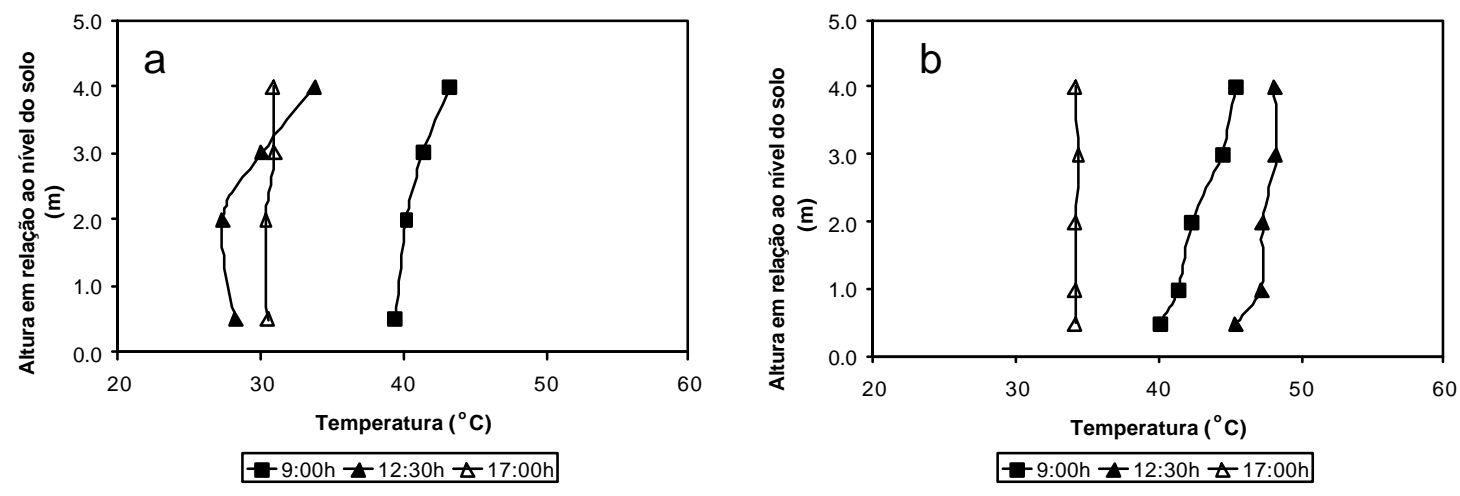

Figura 30. Perfil vertical de temperatura do ar no ambiente protegido com abertura de cortinas laterais e nebulização (a) e ambiente protegido testemunha (b), antes da abertura e nebulização (9:00h), durante (12:30h) e duas horas após o término da nebulização (17:00h), no dia 04/11/99.

Na Figura 31 estão representados os perfis verticais de distribuição de temperatura do ar no ambiente protegido, durante a nebulização. O efeito da nebulização na redução da temperatura do ar no ambiente protegido, independente do horário analisado, ocorreu principalmente de 0,5 a 2,0 m, sendo que seu efeito diminuiu quando se aproximou dos nebulizadores instalados a 3,0 m de altura em relação ao nível do solo. A 4,0 m de altura, a temperatura do ar ficou mais elevada quando comparadas com as demais alturas, durante todo o período com nebulização. A variação de temperatura do ar entre o ponto de menor temperatura $(0,5 \mathrm{~m}$ de altura em relação ao nível do solo) e maior temperatura $(4,0 \mathrm{~m}$ de altura em relação ao nível do solo) foi de $5,0^{\circ} \mathrm{C}$ (às $15: 00 \mathrm{~h}$ ) a $10,4^{\circ} \mathrm{C}$ (às $10: 30 \mathrm{~h}$ ). As maiores diferenças de temperatura do ar entre o nível de $0,5 \mathrm{~m}$ e 4,0 m ocorreram nos períodos mais quentes do dia devido ao maior aquecimento da cobertura plástica, onde a redução de temperatura do ar através da nebulização foi menor, não igualando a temperatura do ar em todo o perfil. Apesar da temperatura do ar a 4,0m de altura estar mais elevada que nas alturas inferiores, no ambiente protegido manejado a temperatura do ar estava a $33,7^{\circ} \mathrm{C}$ enquanto que no ambiente protegido controle a temperatura estava a $48,0^{\circ} \mathrm{C}$, evidenciando a redução na temperatura do ar. 


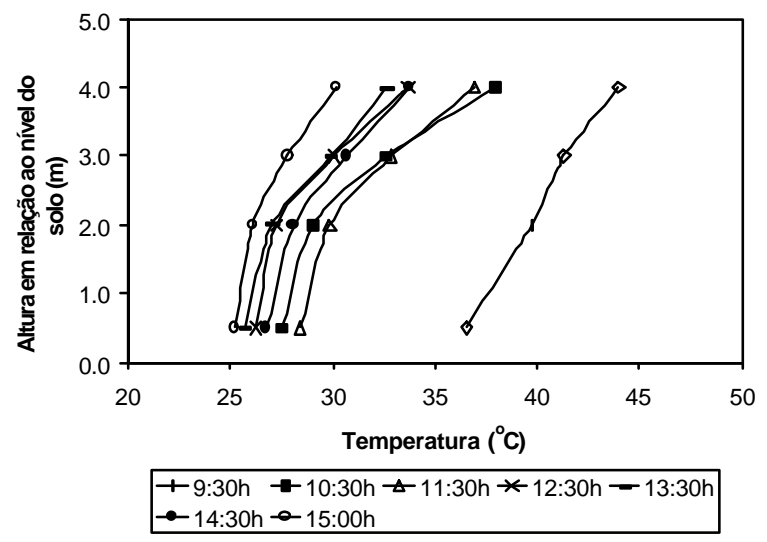

Figura 31. Distribuição vertical de temperatura do ar durante o período em que ocorreu a nebulização (das 9:30h às 15:00h) no dia 04/11/99.

Na Figura 32 estão representadas as isotermas a 0,5m de altura no dia 04/11/99 para o ambiente protegido com nebulização e de cortinas laterais abertas (32a, 32b e 32c) e o ambiente protegido controle (32d, 32e e 32f) para os horários de 9:00h (32a e 32d), 12:30h (32b e 32e), e 17:00h (32c e 32f).

Às 9:00h (Figura 32a e 32d), a variação de temperatura do ar nos diferentes pontos de amostragem nos ambientes protegidos, não tiveram grande amplitude, com variação de $1,5^{\circ} \mathrm{C}$ a $2,5^{\circ} \mathrm{C}$, no ambiente protegido com nebulização e ventilação natural e o ambiente controle, respectivamente. O ambiente protegido testemunha (Figura 32d), imediatamente após a abertura das cortinas laterais e nebulização (Figura 32a), estava com $1,0^{\circ} \mathrm{C}$ de temperatura do ar acima da temperatura do ar no ambiente protegido com abertura de cortinas e nebulização. Num dos períodos de maior elevação de temperatura do ar no ambiente protegido (12:30h), houve efeito da nebulização e ventilação natural na redução da temperatura do ar, (Figuras 32b e 32e). A temperatura do ar no ambiente protegido controle a $0,5 \mathrm{~m}$ de altura em relação ao nível do solo (Figura 32e), variou de 43,5 a $46,5^{\circ} \mathrm{C}$, enquanto que no ambiente protegido com nebulização e ventilação natural (Figura 32b), variou de 27,0 a $31,0^{\circ} \mathrm{C}$, reduzindo cerca de $34,5 \%$ da temperatura do ar, com temperaturas do ar médias a $0,5 \mathrm{~m}$ de 44,6 e $29,2^{\circ} \mathrm{C}$, respectivamente. No ambiente protegido nebulizado (Figura 32b), as isotermas divergiram do centro e longitudinalmente do ambiente protegido, formando uma zona de redução de 
temperatura do ar por efeito do alcance dos nebulizadores que não atingiram as laterais ou pelo efeito da entrada de ar mais seco vindo do ambiente externo. Porém, tal fato também ocorreu quando foi realizada nebulização com as cortinas laterais fechadas (Figura 20), embora com menor amplitude de variação.
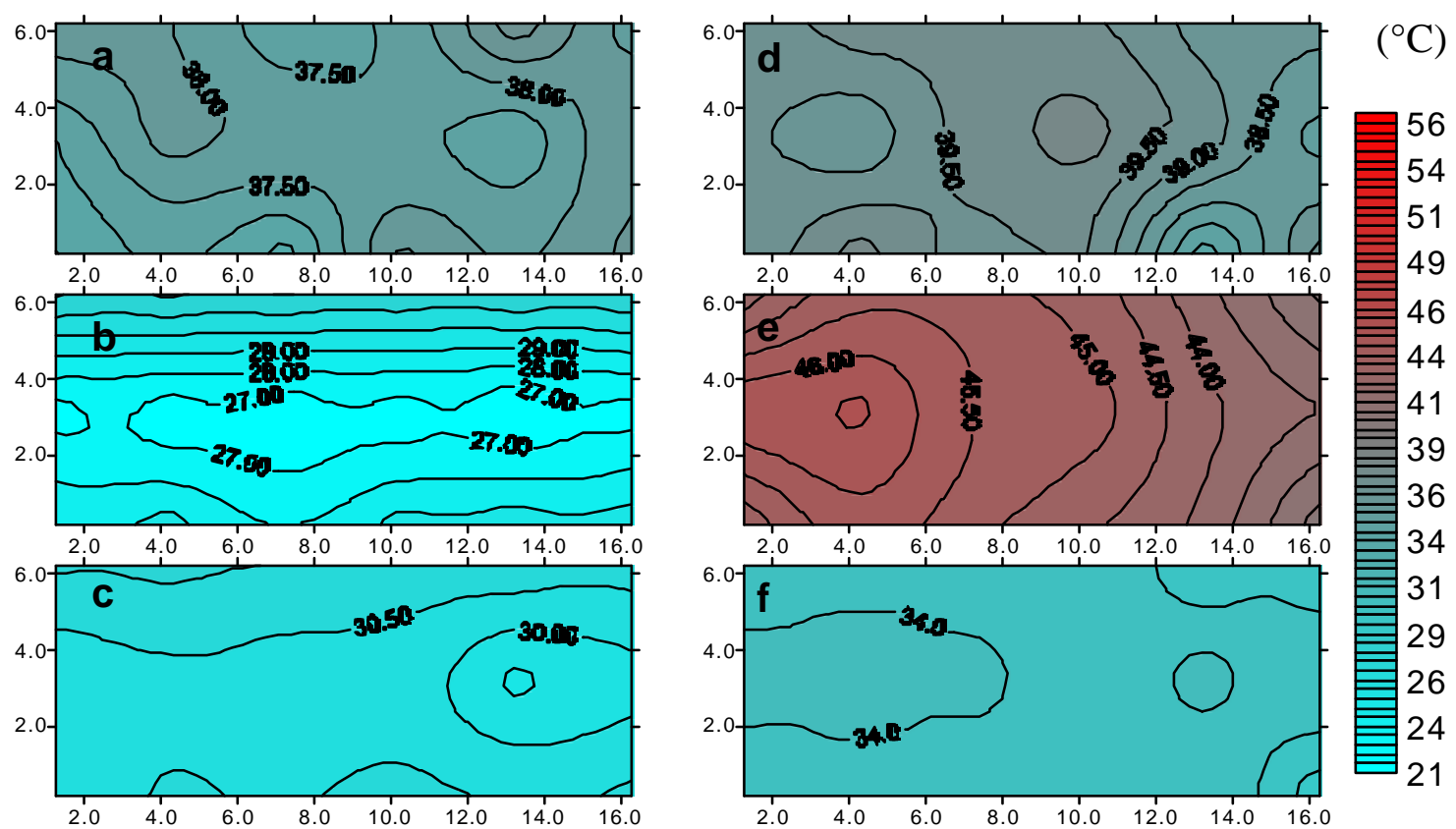

Figura 32. Distribuição de temperatura do ar no ambiente protegido com nebulização e abertura de cortinas laterais (32a, 32b e 32c) e no ambiente protegido controle (32d, 32e e 32f) para os horários de 9:00h (32a e 32d), 12:30h (32b e 32e), e 17:00h (32c e 32f) a 0,5m de altura no dia 04/11/99. O eixo x representa a largura (m) e y o comprimento do ambiente protegido (m).

Nas Figuras 32c e 32f (às 17:00h) estão representadas as distribuições horizontais de temperatura do ar no ambiente protegido após o término da nebulização e após o fechamento das cortinas. A distribuição de temperatura do ar no ambiente protegido nebulizado (Figura 32c) estava com temperaturas inferiores a do ambiente protegido controle (Figura 32f) variando de 30,0 a $31,0^{\circ} \mathrm{C}$ e 33,5 a $34,0^{\circ} \mathrm{C}$, com temperaturas médias de 30,5 e $33,7^{\circ} \mathrm{C}$, respectivamente, mostrando a influência da nebulização e ventilação natural do ambiente na redução da temperatura do ar e seu efeito pós sua interrupção. Ocorreu elevação da temperatura do ar no ambiente protegido após a interrupção da 
nebulização e ventilação natural de cerca de 4,5\%, porém, a temperatura do ar nesse ambiente manteve-se abaixo da temperatura do ar no ambiente controle, conforme visto anteriormente.

Na Figura 33 estão representadas as isotermas a 2,0m de altura no dia 04/11/99 para o ambiente protegido com nebulização e abertura de cortinas laterais (33a, 33b e 33c) e o ambiente protegido controle (33d, 33e e 33f) para os horários de 9:00h (33a e 33d), 12:30h (33b e 33e), e 17:00h (33c e 33f).
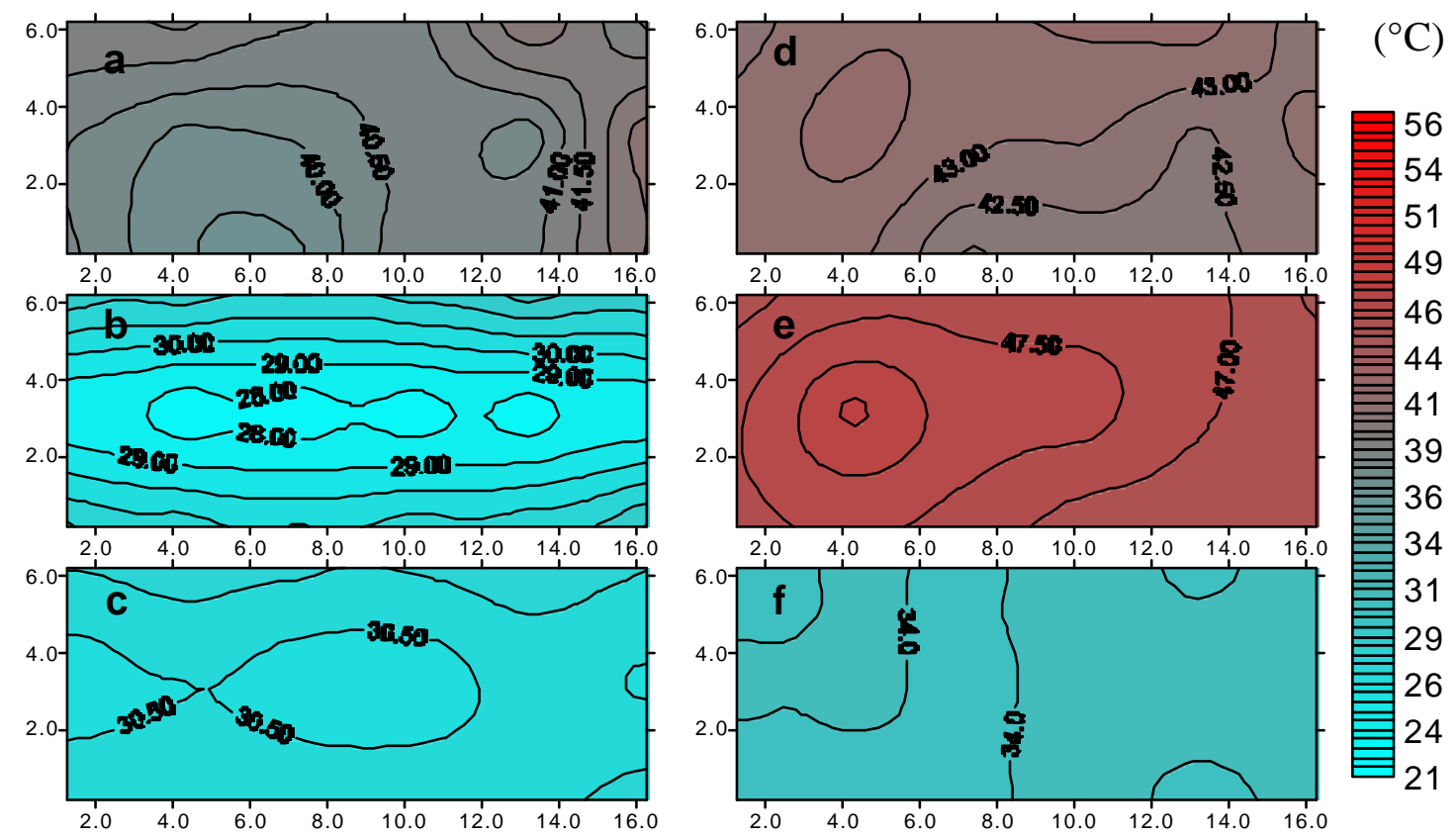

Figura 33. Distribuição de temperatura do ar no ambiente protegido com nebulização e abertura de cortinas laterais (33a, 33b e 33c) e no ambiente protegido controle (33d, 33e e 33f) para os horários de 9:00h (33a e 33d), 12:30h (33b e 33e), e 17:00h (33c e 33f), a 2,0m de altura no dia 04/11/99. O eixo x representa a largura (m) e y o comprimento do ambiente protegido (m).

A 2,0m de altura, temos praticamente a mesma situação ocorrida a $0,5 \mathrm{~m}$, porém com uma pequena elevação da temperatura do ar para os horários de 9:00h e 12:30h. As temperaturas do ar no ambiente protegido com nebulização e ventilação natural às 9:00h (Figura 33a) variaram de 40,0 a $42,0^{\circ} \mathrm{C}$ e de 42,5 a $43,5^{\circ} \mathrm{C}$ no ambiente protegido controle (Figura 33d), com médias de temperatura do ar de 40,9 e $42,8^{\circ} \mathrm{C}$, respectivamente. Às 
12:30h, a variação foi de 28,0 a $32,0^{\circ} \mathrm{C}$ no ambiente protegido com nebulização e ventilação natural e de 46,0 a $47,0^{\circ} \mathrm{C}$ no ambiente controle com médias de 30,7 e $47,1^{\circ} \mathrm{C}$, respectivamente, reduzindo a temperatura do ar em 34,8\%. Às 17:00h, entretanto, não houve aumento de temperatura do ar com a altura, ficando com distribuição de temperatura do ar e valores muito próximos das observadas a $0,5 \mathrm{~m}$, conforme pôde ser também observado na Figura 30.

4.2.3.2. Cortinas laterais abertas a 2,0m de altura em relação ao nível do solo.

4.2.3.2.1. Variação da temperatura do ar no ambiente protegido.

Na Figura 34 está representada a variação da temperatura média do ar no ambiente protegido com cortinas abertas e nebulização (E1) e no ambiente controle (E2), no dia 08/11/99. Às 9:00h as cortinas laterais foram abertas a 2,0m de altura e iniciada a nebulização. Às 15:00h, a nebulização foi cessada e às 15:30h, as cortinas laterais foram fechadas. A redução da temperatura do ar no ambiente protegido manejado em comparação com o ambiente controle foi significativa a 1,0\% de probabilidade pelo teste t.

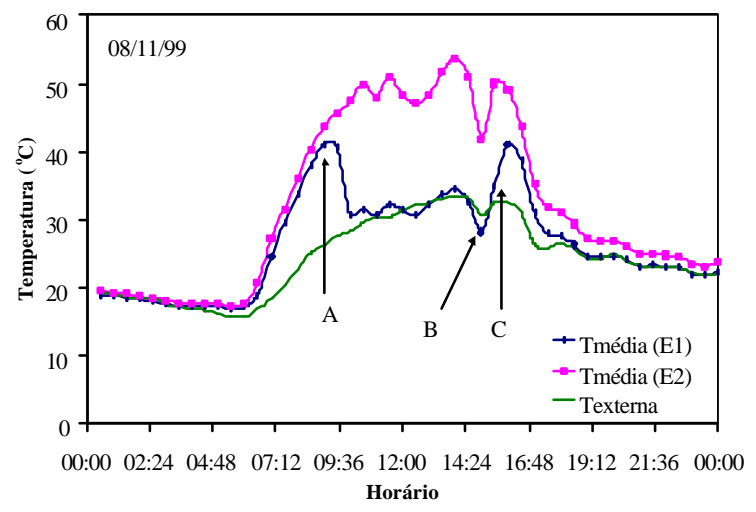

A - abertura das cortinas laterais a 2,0m de altura em relação ao nível do solo e início da nebulização (9:00h)

B - final da nebulização $(15: 00 \mathrm{~h})$

C - fechamento das cortinas laterais $(15: 30 \mathrm{~h})$

Figura 34. Variação da temperatura média do ar no ambiente protegido com nebulização e abertura de cortinas a 2,0m de altura em relação ao nível do solo (E1), no ambiente protegido controle (E2) e no ambiente externo, no dia 08/11/99. 
A temperatura média do ar no ambiente protegido controle no período das 9:00h às $15: 30 \mathrm{~h}$ foi de $48,4^{\circ} \mathrm{C}$ e as temperaturas médias do ar no ambiente protegido com cortinas abertas e nebulização e externa foram de $33,2^{\circ} \mathrm{C}$ e $30,8^{\circ} \mathrm{C}$, respectivamente. A abertura de cortinas e a nebulização reduziu a temperatura do ar no ambiente protegido em relação ao ambiente controle em $15,2^{\circ} \mathrm{C}$, o que representou redução de 31,3\% na temperatura média do ar. Em relação a temperatura do ar externa, o ambiente protegido com cortinas abertas e nebulizado ficou com temperatura do ar $8,0 \%$ superior enquanto que o ambiente controle ficou com temperatura média do ar 57,4\% superior. A umidade relativa do ar, com nebulização, aumentou de 32,2\% para 57,4\%, ou seja, 78,0\% de acréscimo.

$\mathrm{Na}$ Figura 35, observa-se a variação temporal de temperatura média do ar no ambiente protegido controle e com cortinas abertas e nebulização no dia 02/12/99. Nesse dia, a cortina zenital foi aberta às 10:45h. A abertura das cortinas laterais a 2,0m de altura em relação ao nível do solo ocorreu às 12:00h e a nebulização iniciou-se às $12: 45 \mathrm{~h}$. A nebulização terminou às $14: 30 \mathrm{~h}$ e o fechamento das cortinas laterais e zenital ocorreu às $16: 30 \mathrm{~h}$.

A - abertura da cortina zenital (10:45h)

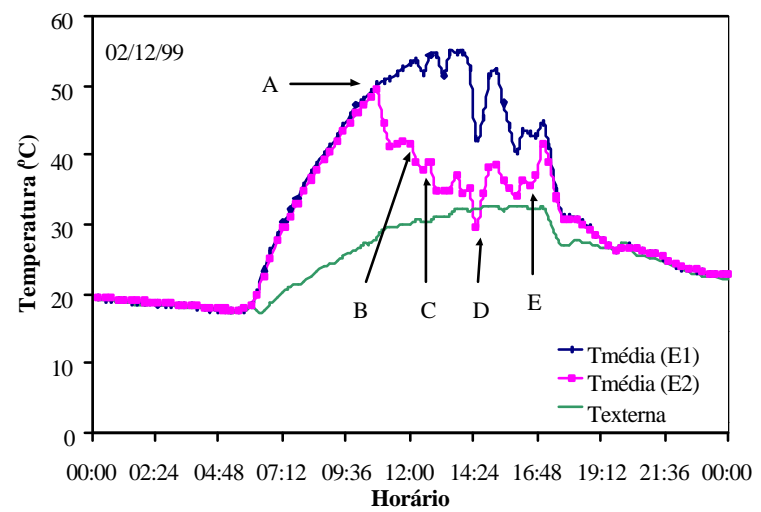

B - abertura das cortinas laterais a 2,0m de altura em relação ao nível do solo (12:00h)

C - início da nebulização $(12: 45 h)$

D - fim da nebulização $(14: 30 h)$

E - fechamento das cortinas $(16: 30 \mathrm{~h})$

Figura 35. Variação da temperatura média do ar no ambiente protegido com nebulização e abertura das cortinas a 2,0m de altura em relação ao nível do solo (E2), no ambiente protegido controle (E1) e no ambiente externo, no dia 02/12/99. 
A redução da temperatura do ar no ambiente protegido manejado em comparação com o ambiente controle foi significativa a 1,0\% de probabilidade pelo teste t.

Nesse dia, a redução entre a temperatura média do ar no ambiente protegido controle e ambiente com cortinas abertas e nebulização foi de $12,4^{\circ} \mathrm{C}(24,7 \%)$. A temperatura média do ar no ambiente protegido controle no período das 10:45 às 16:30h foi de $50,2^{\circ} \mathrm{C}$. A temperatura média do ar no ambiente com cortinas abertas e nebulização (E2) foi de $37,8^{\circ} \mathrm{C}$ e a temperatura do ar externa ficou em $31,3^{\circ} \mathrm{C}$. Isso representou aumento de temperatura do ar no ambiente protegido controle em relação ao ambiente externo de 60,3\% e no ambiente com as cortinas abertas e nebulizado em relação ao externo de 20,8\%. A umidade relativa do ar média para esse período ficou menor no ambiente protegido com as cortinas abertas e nebulizado que no ambiente controle, em 7,0\%, pois com a abertura das cortinas, houve troca de vapor de água acumulado pelo fechamento das cortinas ou evaporado do solo durante as elevadas temperaturas com as cortinas fechadas. Após a nebulização, a umidade relativa no ambiente protegido com cortinas abertas se elevou a 45,6\% (18,0\% acima do ambiente controle).

Nas Figuras 34 e 35, observa-se a variação temporal das temperaturas médias no ambiente protegido controle e ambiente com cortinas abertas e nebulizado e a temperatura média do ar externa durante os dias 08/11 e 02/12/99. Nesses dias, o uso dos métodos combinados de abertura de cortinas e nebulização, proporcionou redução significativa da temperatura do ar no ambiente protegido, chegando até a se equiparar a temperatura do ar externa. O uso de ventilação forçada com ventiladores poderia melhorar a eficiência desse sistema, reduzindo ainda mais a temperatura. $\mathrm{O}$ resfriamento no dia 08/11 foi mais eficiente pela maior renovação do ar no ambiente protegido devido a maior velocidade do vento no ambiente externo que foi de 2,9 m/s. No dia 02/12/99, a velocidade do vento foi de $1,7 \mathrm{~m} / \mathrm{s}$.

Os dias 4 e 8/11/99 (Figuras 27 e 34) tiveram praticamente o mesmo manejo de cortinas e nebulização, porém com altura de abertura de cortina lateral diferentes (dia 04/11/99 com abertura da cortina lateral a 1,0m de altura e dia 08/11/99 com abertura da 
cortina lateral a 2,0m de altura). Observa-se que, mesmo sendo dias diferentes, porém com valores semelhantes de entalpia, as reduções de emperatura do ar entre o ambiente protegido com cortinas abertas e nebulização e o ambiente protegido controle foram semelhantes $\left(14,0^{\circ} \mathrm{C}\right.$ no dia $04 / 11 / 99$ e $15,2^{\circ} \mathrm{C}$ no dia $\left.08 / 11 / 99\right)$. Porém, as diferenças de temperatura entre a temperatura do ar do ambiente protegido com cortinas abertas e nebulização e o ambiente externo foram praticamente as mesmas $\left(2,3^{\circ} \mathrm{C}\right.$ no dia $04 / 11 / 99$ e $2,4^{\circ} \mathrm{C}$ no dia 08/11/99), mostrando que, nessa situação, utilizando-se nebulização, a altura de abertura da cortina lateral teve pouca influência. Nos dias 01e 02/12/99 obtevese resultados semelhantes, porém com reduções um pouco menores para o dia 01/12/99 com abertura da cortina lateral a 1,0m de altura quando comparado com o dia 02/12/99 que teve abertura de cortinas laterais a 2,0m de altura. Talvez, isso tenha ocorrido devido ao maior acúmulo de calor, maior aquecimento da estrutura, do solo e do ar nos ambientes protegidos ocorrido pelo início tardio da nebulização e pelo menor tempo de manejo das cortinas e nebulização, diminuindo o tempo de permanência das cortinas abertas e, consequentemente, da renovação de ar no ambiente protegido.

4.2.3.2.2. Variação vertical e horizontal de temperatura do ar.

No dia 08/11/99, no ambiente protegido manejado, as cortinas laterais foram abertas a 2,0m de altura em relação ao nível do solo e acionado o sistema de nebulização intermitente às 9:00h. Às 15:00h, o nebulizador foi desligado e às 15:30h, foram fechadas as cortinas.

Na Figura 36a estão representados os perfis de distribuição de temperatura no dia 08/11/99, no ambiente protegido onde houve abertura de cortinas laterais a 2,0m de altura e nebulização e na Figura 36b estão representados os perfis de temperatura do ar no ambiente protegido controle. Às 9:00h, representa o horário anterior ao manejo das cortinas e nebulização, quando os ambientes protegidos apresentaram condições de distribuição de temperatura do ar muito semelhantes, com temperaturas próximas a $41,0^{\circ} \mathrm{C}$ ao nível de $0,5 \mathrm{~m}$ de altura e ao redor de $47,0^{\circ} \mathrm{C}$ ao nível de $4,0 \mathrm{~m}$. No perfil determinado às $12: 30 \mathrm{~h}$ na Figura 36a em comparação com a Figura 36b, observa-se claramente o efeito da redução de 
temperatura do ar pela nebulização e ventilação natural. Nesse horário as cortinas estavam abertas e a nebulização estava acionada, reduzindo a temperatura média do ar no ambiente em cerca de $17,8^{\circ} \mathrm{C}$, ou $37,5 \%$, com valores médios de temperatura do ar no perfil de $47,5^{\circ} \mathrm{C}$ no ambiente protegido testemunha e de $29,7^{\circ} \mathrm{C}$ no ambiente com nebulização e ventilação natural. O perfil das 17:00h representa o período após o encerramento da nebulização e o fechamento das cortinas. Nesse horário, houve distribuição homogênea de temperatura do ar em todo o perfil, porém, com valores médios de $30,8^{\circ} \mathrm{C}$ no ambiente protegido, onde houve nebulização e ventilação natural e $35,5^{\circ} \mathrm{C}$ no ambiente controle, evidenciando o efeito de redução de temperatura do ar pela nebulização mesmo após o seu encerramento.
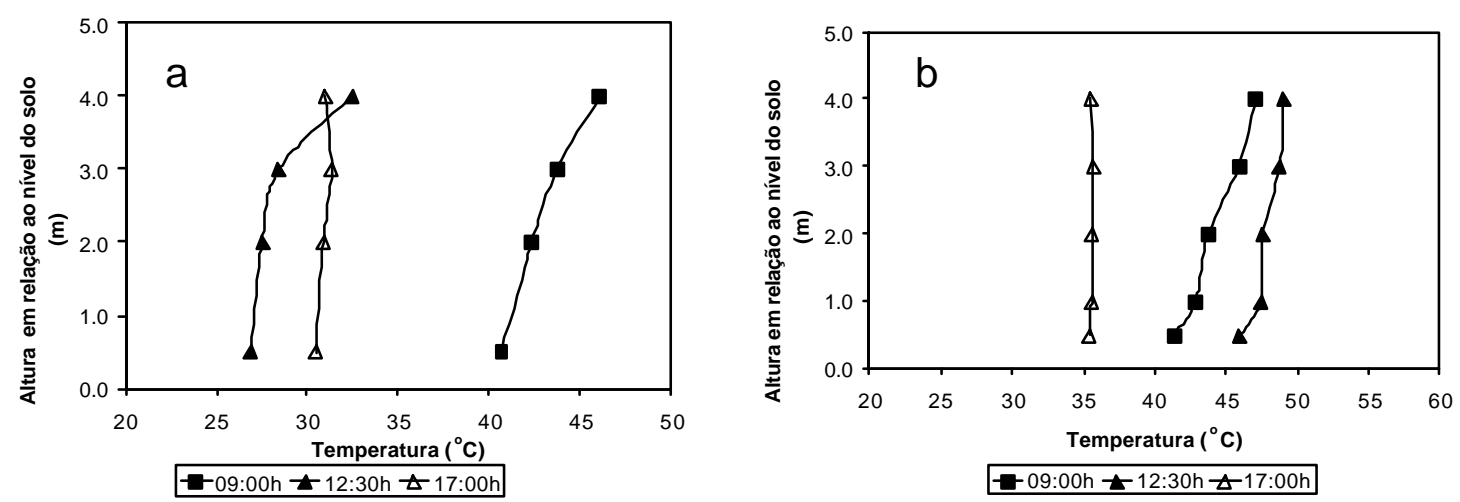

Figura 36. Perfil vertical de temperatura do ar no ambiente protegido com abertura de cortinas laterais a 2,0m de altura e nebulização (a) e ambiente protegido testemunha (b), antes da abertura e nebulização (9:00h), durante (12:30h) e após o término da nebulização e fechamento das cortinas laterais (17:00h), no dia 08/11/99.

O efeito da nebulização na redução da temperatura do ar no ambiente protegido, ocorreu principalmente de 0,5 a 3,0 m. A 4,0 m de altura, a temperatura do ar ficou mais elevada quando comparada com as demais alturas, durante todo o período com nebulização, porém, com temperaturas do ar menores que no ambiente protegido controle.

Na Figura 37 estão representadas as isotermas a 0,5m de altura no dia 08/11/99 para o ambiente protegido com nebulização e abertura de cortinas laterais $(37 \mathrm{a}, 37 \mathrm{~b}$ e 
37c) e o ambiente protegido controle (37d, 37e e 37f) para os horários de 9:00h (37a e 37d), 12:30h (37b e 37e), e 17:00h (37c e 37f).
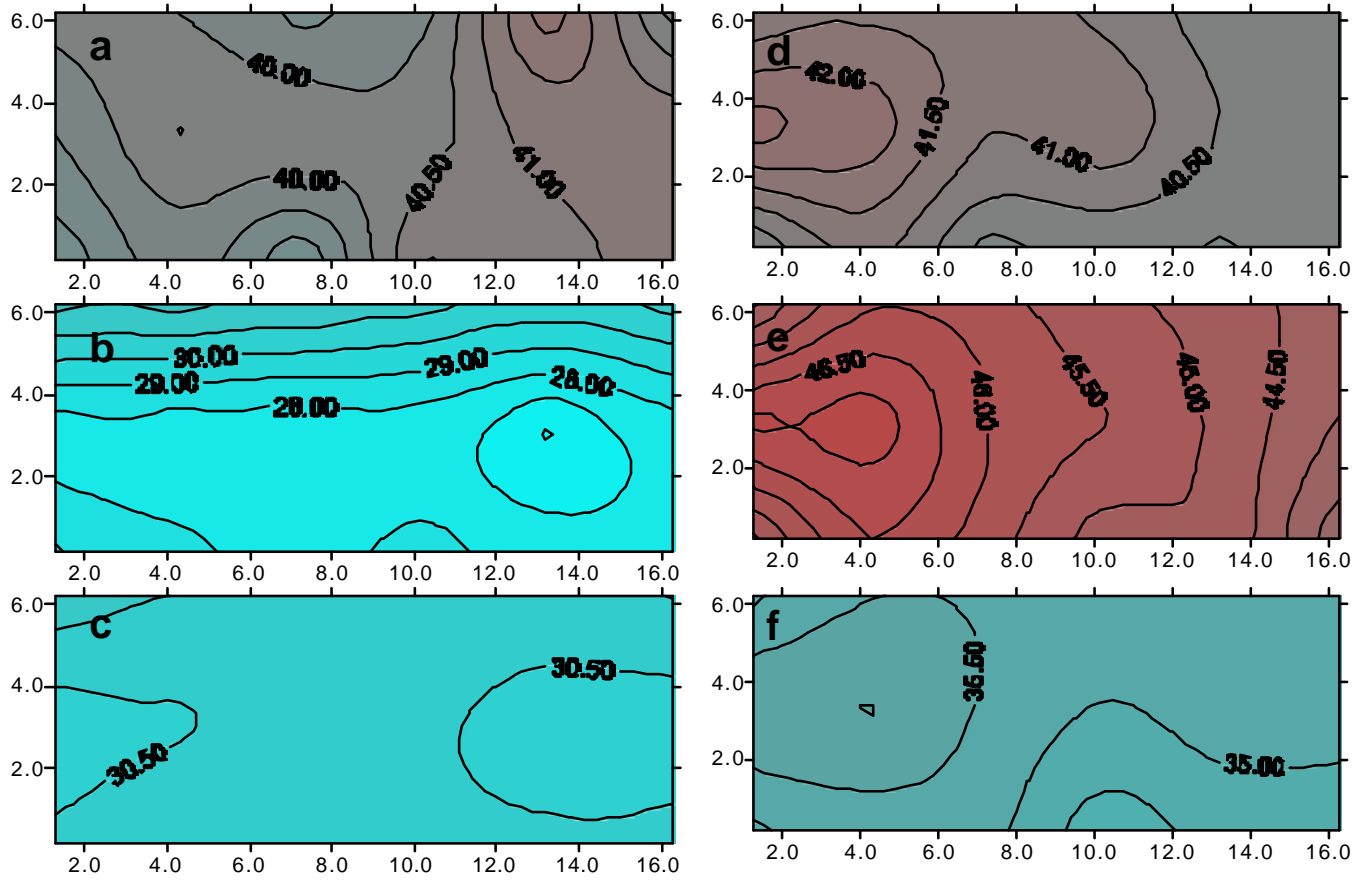

Figura 37. Distribuição de temperatura do ar no ambiente protegido com nebulização e abertura de cortinas laterais $(37 \mathrm{a}, 37 \mathrm{~b}$ e 37c) e no ambiente protegido controle (37d, 37e e 37f) para os horários de 9:00h (37a e 37d), 12:30h (37b e 37e), e 17:00h (37c e 37f) a 0,5m de altura no dia 08/11/99. O eixo x representa a largura (m) e y o comprimento do ambiente protegido (m).

Às 9:00h (Figura 37a e 37d), a variação de temperatura do ar nos diferentes pontos de amostragem nos ambientes protegidos, foi de $2,0^{\circ} \mathrm{C}$ a $1,5^{\circ} \mathrm{C}$, com médias de temperatura do ar a $0,5 \mathrm{~m}$ de altura de 40,1 e $40,7^{\circ} \mathrm{C}$, no ambiente protegido com nebulização e ventilação natural e o ambiente controle, respectivamente. Às 12:30h, houve efeito da nebulização e ventilação natural na redução da temperatura do ar, conforme observado nas Figuras 37b e 37e. A temperatura do ar no ambiente protegido controle a 0,5m de altura em relação ao nível do solo (Figura 37e), variou de 44,0 a $47,0^{\circ} \mathrm{C}$, enquanto que no ambiente protegido com nebulização e ventilação natural (Figura 37 b), variou de 27,0 a $31,0^{\circ} \mathrm{C}$, reduzindo cerca de $35,8 \%$ da temperatura do ar, 
com temperaturas do ar médias a $0,5 \mathrm{~m}$ de 45,2 e $29,0^{\circ} \mathrm{C}$, respectivamente. No ambiente protegido nebulizado (Figura 37b), as isotermas divergiram do centro e longitudinalmente no ambiente protegido por efeito da nebulização.

Nas Figuras 37c e 37f (às 17:00h) estão representadas as distribuições horizontais de temperatura do ar no ambiente protegido após o término da nebulização e após o fechamento das cortinas. Apesar da distribuição homogênea de temperatura do ar no ambiente protegido, a temperatura média do ar no ambiente protegido nebulizado (Figura 37c) ficou inferior a do ambiente protegido controle (Figura 37f), com temperaturas médias de 31,0 e $35,3^{\circ} \mathrm{C}$, respectivamente. Ocorreu elevação da temperatura do ar no ambiente protegido após a interrupção da nebulização e ventilação natural de $5,9 \%$ (de $29,0^{\circ} \mathrm{C}$ às 12:00h para $30,7^{\circ} \mathrm{C}$ às $17: 00 \mathrm{~h}$ ), porém, a temperatura do ar nesse ambiente manteve-se abaixo da temperatura do ar no ambiente controle, conforme visto anteriormente.

Na Figura 38 estão representadas as isotermas a 2,0m de altura no dia 08/11/99 para o ambiente protegido com nebulização e abertura de cortinas laterais (38a, 38b e 38c) e o ambiente protegido controle (38d, 38e e 38f) para os horários de 9:00h (38a e 38d), 12:30h (38b e 38e), e 17:00h (38c e 38f).

Observa-se que a 2,0m de altura (Figura 38), houve elevação da temperatura do ar, quando comparado com a temperatura a 0,5m de altura (Figura 37), para os horários de 9:00h e 12:30h. As temperaturas do ar no ambiente protegido com nebulização e ventilação natural às 9:00h (Figura 38a) variaram de 42,0 a 44, $0^{\circ} \mathrm{C}$ e de 44,0 a $45,0^{\circ} \mathrm{C}$ no ambiente protegido controle (Figura 38d), com médias de temperatura do ar de 43,2 e 44,1 ${ }^{\circ} \mathrm{C}$, respectivamente. Às $12: 30 \mathrm{~h}$, a variação foi de 28,0 a $32,0^{\circ} \mathrm{C}$ no ambiente protegido com nebulização e ventilação natural e de 47,0 a $48,5^{\circ} \mathrm{C}$ no ambiente controle com médias de 30,7 e $47,4^{\circ} \mathrm{C}$, respectivamente, reduzindo a temperatura do ar em 35,2\%. Às 17:00h, entretanto, não houve aumento de temperatura do ar com a altura, ficando com distribuição de temperatura do ar e valores muito próximos das observadas a $0,5 \mathrm{~m}$, conforme pôde ser também observado na Figura 36. As temperaturas médias do perfil horizontal para 17:00h foram de $31,0^{\circ} \mathrm{C}$ para o ambiente protegido com nebulização e cortinas abertas $\left(30,7^{\circ} \mathrm{C}\right.$ para $0,5 \mathrm{~m}$ de altura) e $35,3^{\circ} \mathrm{C}$ para o ambiente protegido controle $\left(35,1^{\circ} \mathrm{C}\right.$ para $0,5 \mathrm{~m}$ de altura). A redução de temperatura do ar foi de $12,2 \%$. 

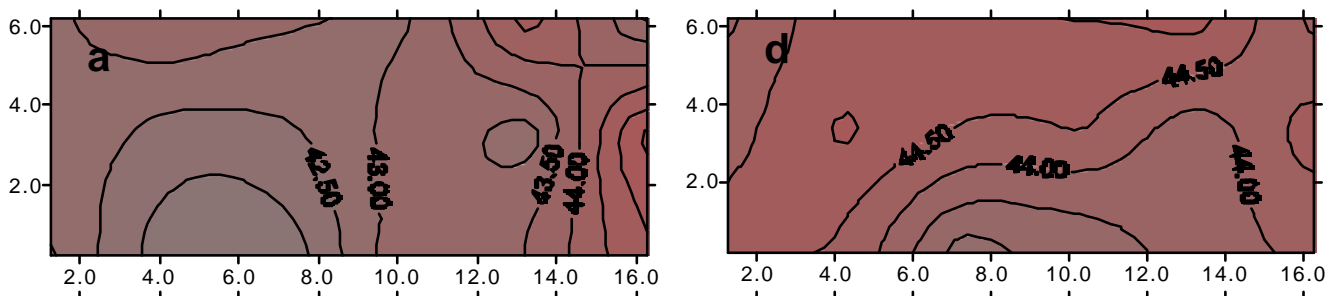

$\left({ }^{\circ} \mathrm{C}\right)$
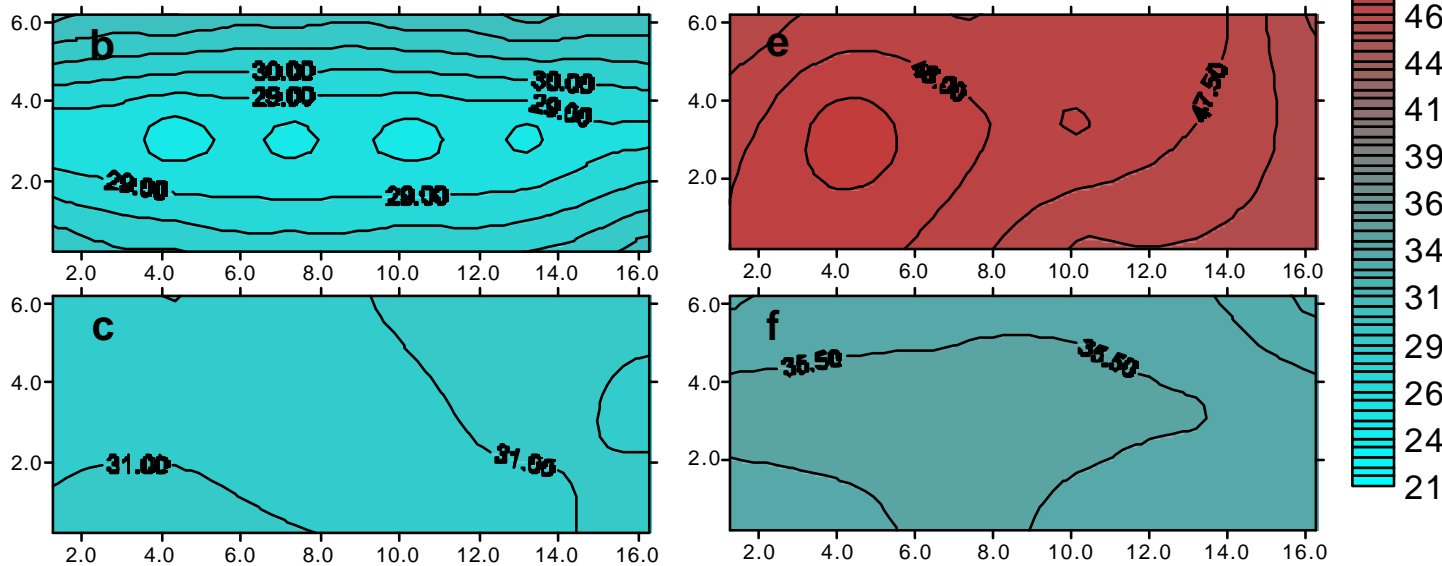

Figura 38. Distribuição de temperatura do ar no ambiente protegido com nebulização e abertura de cortinas laterais $(38 \mathrm{a}, 38 \mathrm{~b}$ e $38 \mathrm{c})$ e no ambiente protegido controle (38d, 38e e 38f) para os horários de 9:00h (38a e 38d), 12:30h (38b e 38e), e 17:00h (38c e 38f), a 2,0m de altura no dia 08/11/99. O eixo x representa a largura (m) e y o comprimento do ambiente protegido (m).

4.2.4. Efeito da abertura de cortinas zenitais, com diferentes alturas de abertura de cortinas laterais.

De 25 de março a 20 de maio de 2000 foram realizados manejos de abertura de cortinas zenitais com diferentes aberturas de cortinas laterais comparando com ambientes protegidos sem abertura de cortina zenital e com diferentes aberturas de cortinas laterais. Entretanto, foram selecionados dois dias de cada uma das diferentes aberturas de cortinas. 
4.2.4.1. Cortinas laterais abertas a $0,5 \mathrm{~m}$ de altura.

4.2.4.1.1. Variação da temperatura do ar no ambiente protegido.

O efeito da redução da temperatura do ar no ambiente protegido através da renovação do ar pelo manejo das cortinas, pode ser observado nas Figuras 39 e 40.

Mantendo-se os ambientes protegidos com as cortinas laterais abertas a 0,5m de altura, comparou-se a variação de temperatura média do ar nos ambientes protegidos, onde em um deles foi realizada a abertura da cortina zenital. Na Figura 39 observa-se a redução da temperatura média do ar no ambiente protegido (E2) onde a cortina zenital foi aberta, em comparação com o ambiente protegido testemunha (E1) para o dia 23/04/00. A redução da temperatura do ar no ambiente protegido manejado em comparação com o ambiente controle foi significativa a 1,0\% de probabilidade pelo teste t. Às 11:00h foi aberta a cortina zenital do ambiente protegido (E1) sendo fechada posteriormente às 15:00h. A temperatura média do ar nesse intervalo para o ambiente testemunha (E2) foi de $42,5^{\circ} \mathrm{C}$ e a média para o ambiente com abertura da cortina zenital foi de $35,9^{\circ} \mathrm{C}$. Houve redução de $6,6^{\circ} \mathrm{C}$, a qual representou redução de $15,6 \%$ da temperatura média do ar no ambiente protegido testemunha.

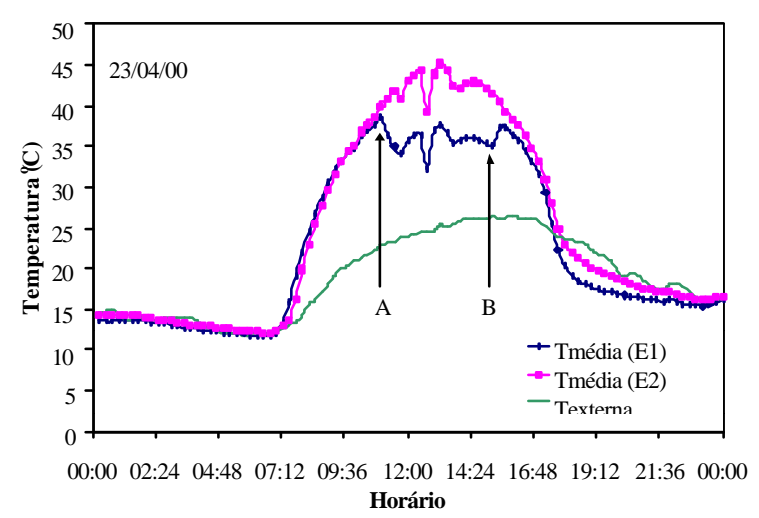

A - abertura da cortina zenital (11:00h).

B - cortina zenital fechada (15:00h)

Figura 39. Variação da temperatura média do ar no ambiente protegido com abertura da cortina zenital e cortina lateral a 0,5m (E1), no ambiente protegido controle com as cortinas laterais abertas a 0,5m (E2) e no ambiente externo, no dia 23/04/00. 
Na Figura 39 estão representadas as variações de temperatura do ar no ambiente externo durante o dia 23. A temperatura do ar externa média para esse intervalo foi de $24,8^{\circ} \mathrm{C}$, ficando o ambiente protegido com as cortinas zenitais abertas com temperatura do ar 44,8\% superior à externa e o ambiente protegido testemunha com 71,4\% acima da temperatura do ar externa.

Na Figura 40, observa-se a redução da temperatura média do ar no ambiente protegido onde foi aberta a cortina zenital (E1) em comparação com o ambiente protegido testemunha (E2) no dia 24/04/00. A cortina zenital foi aberta às 11:00h sendo fechada às 15:00h. Na Figura 40 estão representadas as variações de temperatura do ar no ambiente externo durante o dia 24/04/00. A redução da temperatura do ar no ambiente protegido manejado em comparação com o ambiente controle foi significativa a $1,0 \%$ de probabilidade pelo teste $\mathrm{t}$.

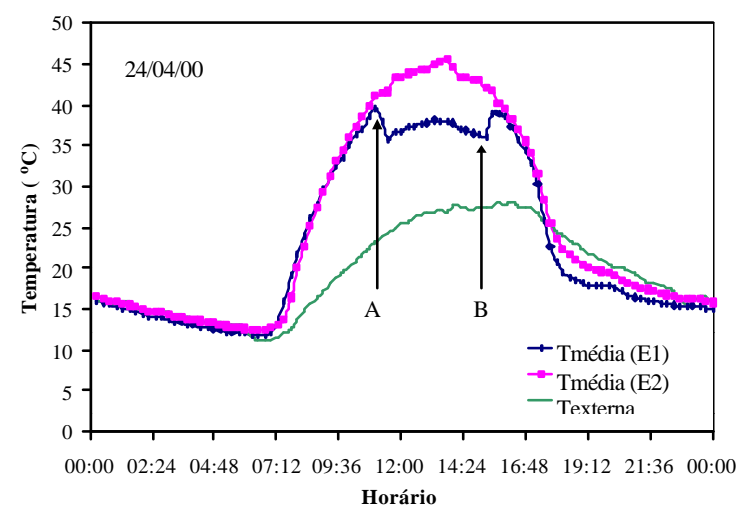

A - abertura da cortina zenital (11:00h).

B - cortina zenital fechada (15:00h)

Figura 40. Variação da temperatura média do ar no ambiente protegido com abertura da cortina zenital e cortina lateral a $0,5 \mathrm{~m}$ (E1), no ambiente protegido controle com as cortinas laterais abertas a $0,5 \mathrm{~m}$ (E2) e no ambiente externo, no dia 24/04/00.

A temperatura média do ar nesse intervalo para o ambiente testemunha (E2) foi de $43,6^{\circ} \mathrm{C}$ e a média nesse mesmo intervalo para o ambiente com a cortina zenital aberta foi de $37,4^{\circ} \mathrm{C}$. A diferença de $6,2^{\circ} \mathrm{C}$ representa uma temperatura média do ar $14,2 \%$ inferior quando comparada com o ambiente testemunha. A temperatura do ar externa média para esse intervalo foi de $26,2^{\circ} \mathrm{C}$, ficando o ambiente protegido manejado com 
temperatura do ar 42,7\% superior à temperatura do ar externa e o ambiente testemunha, com $63,9 \%$ acima da temperatura do ar externa.

Nesses dias, a relação entre a temperatura do ar externa e a temperatura do ar no ambiente protegido testemunha manteve-se praticamente a mesma. Nesse período verificou-se que a velocidade média do vento no ambiente externo foi de $1,3 \mathrm{~m} / \mathrm{s}$ e 1,0m/s para os dias 23 e 24/04/00, respectivamente. A umidade relativa para esse período considerado foi de 56,1 e 53,4\%, para os dias 23 e 24/04/00, respectivamente.

\subsection{Variação vertical e horizontal de temperatura do ar.}

$\mathrm{Na}$ Figura 41a estão representados os perfis verticais de distribuição de temperatura média do ar no dia 24/04/00 no ambiente protegido onde houve abertura da cortina zenital com as cortinas laterais abertas a 0,5m de altura e na Figura $41 \mathrm{~b}$ estão representados os perfis verticais de distribuição de temperatura média do ar no ambiente protegido controle com as cortinas laterais abertas a $0,5 \mathrm{~m}$ de altura em relação ao nível do solo.
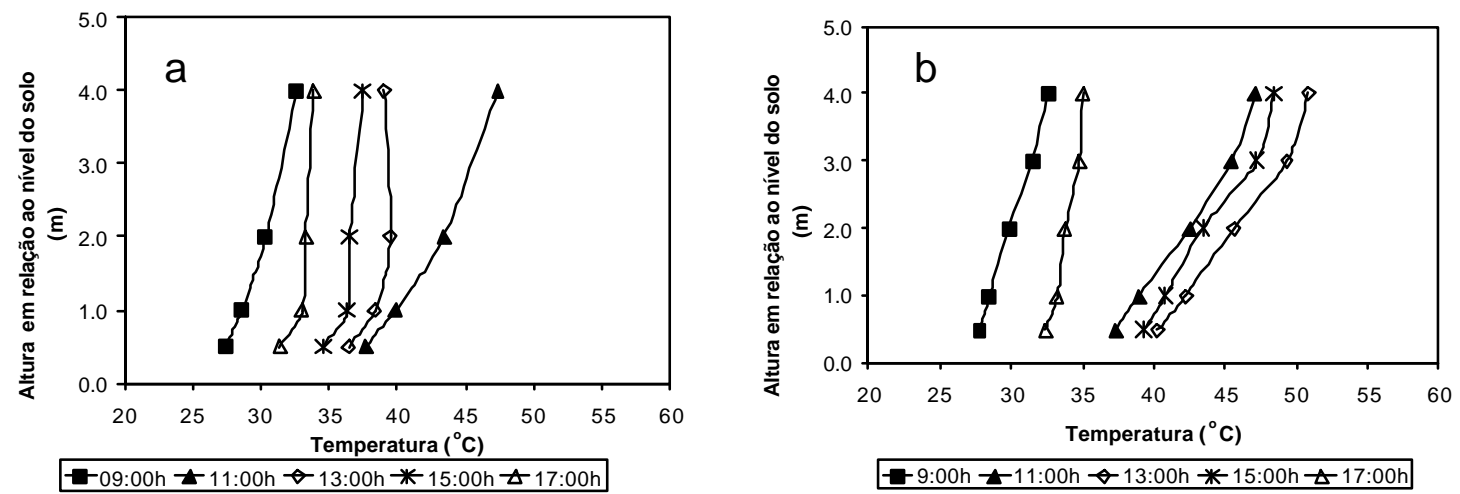

Figura 41. Perfil vertical de temperatura do ar no ambiente protegido com cortinas laterais abertas a $0,5 \mathrm{~m}$ de altura e abertura da cortina zenital (a) e no ambiente protegido testemunha com cortinas laterais abertas a 0,5m (b), antes da abertura da cortina zenital (9:00h), na abertura (11:00h), durante o período em que a cortina permaneceu aberta (13:00h), no fechamento (15:00h) e após o fechamento da cortina zenital (17:00h), no dia 24/04/00. 
Às 9:00h, representa o horário anterior a abertura da cortina zenital, porém com as cortinas laterais abertas a $0,5 \mathrm{~m}$ de altura. Nessas condições, os ambientes protegidos se encontravam com a mesma distribuição de temperatura do ar, chegando a valores próximos a $27,5^{\circ} \mathrm{C}$ ao nível de $0,5 \mathrm{~m}$ de altura e ao redor de $32,6^{\circ} \mathrm{C}$ ao nível de $4,0 \mathrm{~m}$ de altura. No perfil determinado no momento da abertura da cortina zenital (11:00h) na Figura 41a e 41b, os ambientes protegidos apresentavam temperaturas do ar ao redor de $37,5^{\circ} \mathrm{C}$ a $0,5 \mathrm{~m}$ de altura e cerca de $47,0^{\circ} \mathrm{C}$ a $4,0 \mathrm{~m}$ de altura. Nos perfis verticais determinados antes da abertura da cortina zenital, observa-se o aumento da temperatura média do ar com o aumento na altura de coleta de dados, nos ambientes protegidos, chegando a temperatura do ar máxima a 4,0m de altura onde a concentração de ar quente é maior no ambiente protegido. A abertura de $0,5 \mathrm{~m}$ de altura das cortinas laterais teve pouco efeito na redução de temperatura do ar. Após abertura da cortina zenital às 13:00h, no ambiente protegido manejado em comparação com o ambiente protegido controle observou-se o efeito da redução de temperatura média do ar pela abertura da cortina zenital e diminuição do gradiente de temperatura do ar a partir de $1,0 \mathrm{~m}$ de altura em relação ao nível do solo, proporcionando uma temperatura média do ar homogênea no perfil. Entretanto, no ambiente protegido controle a temperatura do ar se elevou a medida que houve elevação na altura analisada. A temperatura média do ar no perfil vertical no ambiente protegido manejado foi de $37,7^{\circ} \mathrm{C}$, com amplitude de variação de $36,4^{\circ} \mathrm{C}$ a $39,0^{\circ} \mathrm{C}$ a $0,5 \mathrm{~m}$ e a $4,0 \mathrm{~m}$ de altura, respectivamente, enquanto que a temperatura média do ar no ambiente protegido controle foi de $45,6^{\circ} \mathrm{C}$, com temperatura média do ar de $40,3^{\circ} \mathrm{C}$ a $0,5 \mathrm{~m}$ e de $50,8^{\circ} \mathrm{C}$ a $4,0 \mathrm{~m}$ de altura. A abertura da cortina zenital nesse horário proporcionou redução média de temperatura do ar de $17,3 \%$. No perfil correspondente às 15:00h, obtivemos a mesma tendência de distribuição vertical de temperatura do ar observada no perfil das 13:00h. A temperatura média do ar no perfil vertical no ambiente protegido manejado foi de $36,1^{\circ} \mathrm{C}$, com temperatura média do ar de $34,6^{\circ} \mathrm{C}$ a $0,5 \mathrm{~m}$ e de $37,5^{\circ} \mathrm{C}$ a $4,0 \mathrm{~m}$ de altura e a temperatura média do ar no perfil vertical no mbiente protegido controle foi de $43,9^{\circ} \mathrm{C}$, com temperatura média do ar de $39,3^{\circ} \mathrm{C}$ a $0,5 \mathrm{~m}$ e $48,4^{\circ} \mathrm{C}$ a $4,0 \mathrm{~m}$, com redução média de temperatura do ar de 17,8\%. Nos ambientes protegidos, os perfis correspondentes às 17:00h, a distribuição de temperatura do ar foram semelhantes com pequena diferença de 
temperatura entre as alturas, porém maiores no ambiente protegido controle. A temperatura média do ar do perfil vertical no ambiente protegido com cortina zenital aberta foi de $32,7^{\circ} \mathrm{C}$, com temperatura média do ar de $31,4^{\circ} \mathrm{C}$ a $0,5 \mathrm{~m}$ e de $33,9^{\circ} \mathrm{C}$ a $4,0 \mathrm{~m}$ de altura e a temperatura média do ar no perfil vertical no ambiente protegido controle foi de $33,7^{\circ} \mathrm{C}$, com temperatura média do ar de $32,4^{\circ} \mathrm{C}$ a $0,5 \mathrm{~m}$ e $35,0^{\circ} \mathrm{C}$ a $4,0 \mathrm{~m}$, representando redução média de temperatura do ar de 3,0\%.

$\mathrm{Na}$ Figura 42 estão representadas as isotermas a 0,5m de altura no dia 24/04/00 para o ambiente protegido com cortinas laterais abertas a $0,5 \mathrm{~m}$ e abertura de cortina zenital (42a, 42b e 42c) e no ambiente protegido controle com cortinas laterais abertas a 0,5m de altura (42d, 42e e 42f) para os horários de 11:00h (42a e 42e), 13:00h (42b e 42f), 15:00h (42c e 42g) e 17:00h (42d e 42h).

No perfil correspondente às 11:00h (Figuras 42a e 42e) a variação de temperatura do ar nos ambientes protegidos foi de cerca de $2,0^{\circ} \mathrm{C}$, com temperaturas menores nas laterais por estarem as cortinas laterais abertas a $0,5 \mathrm{~m}$ de altura. Nesse horário, a velocidade do vento foi de $0,9 \mathrm{~m} / \mathrm{s}$, sudeste. A temperatura média do ar do perfil horizontal foi de 34,6 e $34,4^{\circ} \mathrm{C}$ para o ambiente protegido manejado e testemunha, respectivamente.

Às 13:00h, com a cortina zenital aberta (Figura 42b) a distribuição de temperatura do ar no ambiente protegido foi irregular, enquanto que no ambiente protegido testemunha houve a mesma distribuição que às 11:00h, com temperaturas menores nas laterais (Figura 42f). A temperatura média do ar no perfil no ambiente protegido com cortina zenital aberta foi de $36,3^{\circ} \mathrm{C}$, enquanto que a temperatura média do ar no perfil no ambiente protegido controle foi de $37,7^{\circ} \mathrm{C}$. A abertura da janela zenital reduziu a temperatura média do ar no perfil de $3,7 \%$. No momento do fechamento da cortina zenital (15:00h), a distribuição de temperatura do ar nos ambientes protegidos permaneceu a mesma, porém, com temperaturas médias do ar de 34,6 e $38,1^{\circ} \mathrm{C}$, para o ambiente com cortina zenital aberta (Figura 42c) e testemunha (Figura 42g), respectivamente, sendo que a temperatura média do ar sofreu redução de $9,2 \%$. 

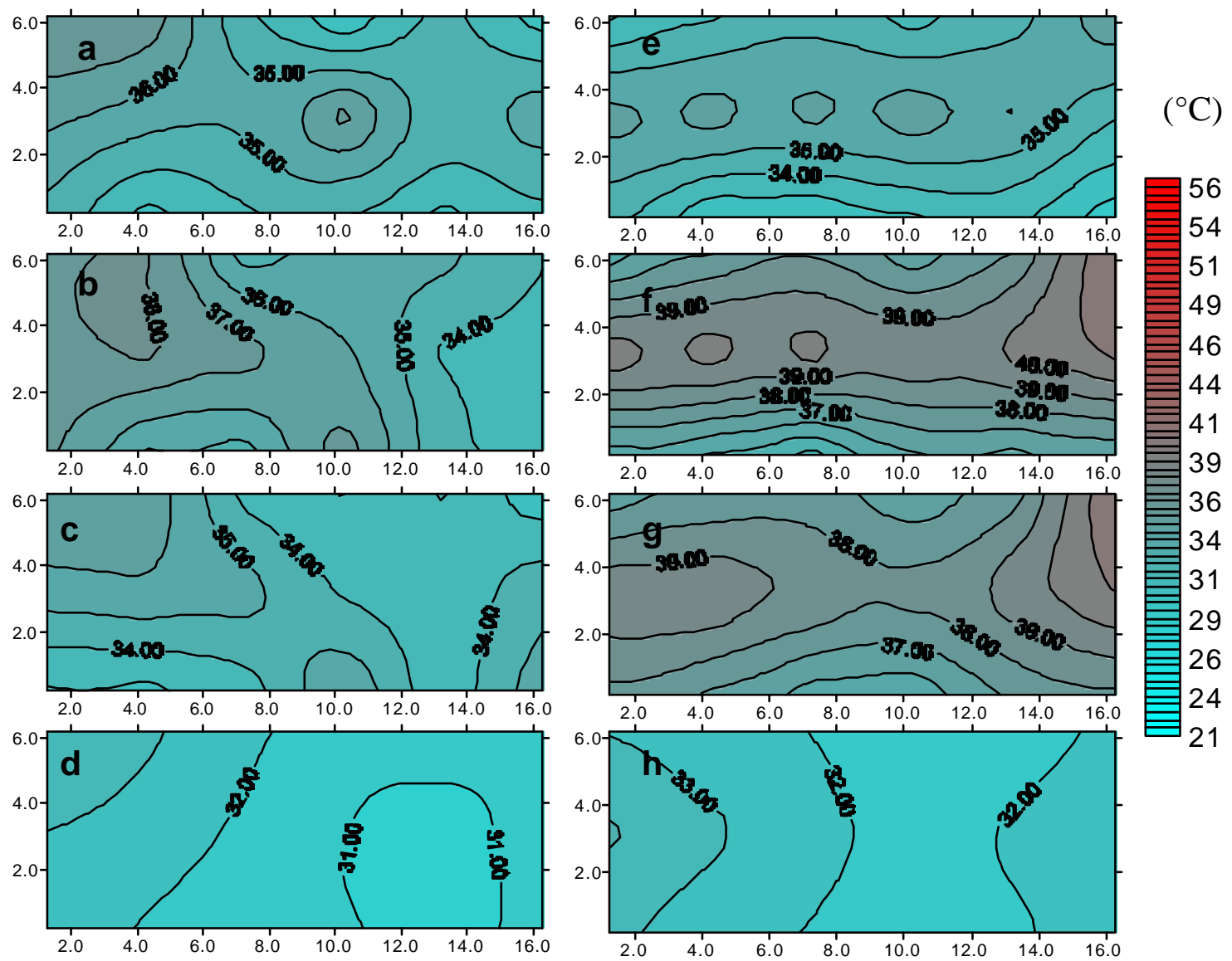

Figura 42. Distribuição de temperatura do ar no ambiente protegido com cortinas laterais abertas a $0,5 \mathrm{~m}$ de altura e abertura de cortina zenital (42a, 42b e 42c) e no ambiente protegido controle com cortinas laterais abertas a $0,5 \mathrm{~m}$ de altura (42d, 42e e 42f) para os horários de 11:00h (42a e 42e), 13:00h (42b e 42f), 15:00h (42c e 42g) e 17:00h (42d e 42h) a 0,5m de altura no dia 24/04/00. O eixo $\mathrm{x}$ representa a largura $(\mathrm{m})$ e $\mathrm{y}$ o comprimento do ambiente protegido (m).

Nas Figuras 42d e 42h (às 17:00h) estão representadas as distribuições horizontais de temperatura do ar no ambiente protegido após o fechamento da cortina zenital. A distribuição de temperatura do ar no ambiente protegido com abertura de cortina zenital (Figura 42d) teve temperaturas inferiores a no ambiente protegido controle (Figura $42 \mathrm{~h}$ ) variando de 33,0 a $31,0^{\circ} \mathrm{C}$ (e temperatura média do ar no perfil de 
$31,9^{\circ} \mathrm{C}$ ) e de 33,0 a $32,0^{\circ} \mathrm{C}$ (e temperatura média do ar no perfil de $32,5^{\circ} \mathrm{C}$ ), respectivamente, ou seja, cerca de $1,9 \%$ inferior.

Na Figura 43 estão representadas as isotermas a 2,0m de altura no dia 24/04/00 para o ambiente protegido com cortinas laterais abertas a $0,5 \mathrm{~m}$ e abertura de cortina zenital (43a, 43b e 43c) e o ambiente protegido controle com cortinas laterais abertas a 0,5m de altura (43d, 43e e 43f) para os horários de 11:00h (43a e 43e), 13:00h (43b e 43f), 15:00h (43c e 43g) e 17:00h (43d e 43h).
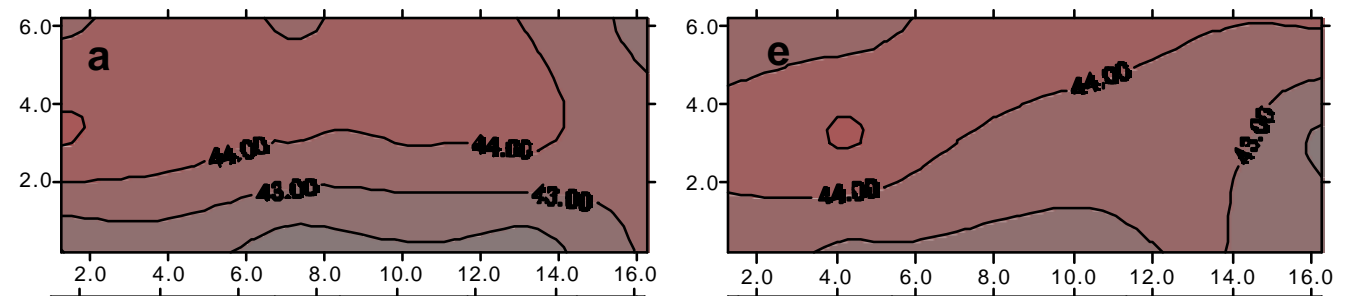

$\left({ }^{\circ} \mathrm{C}\right)$
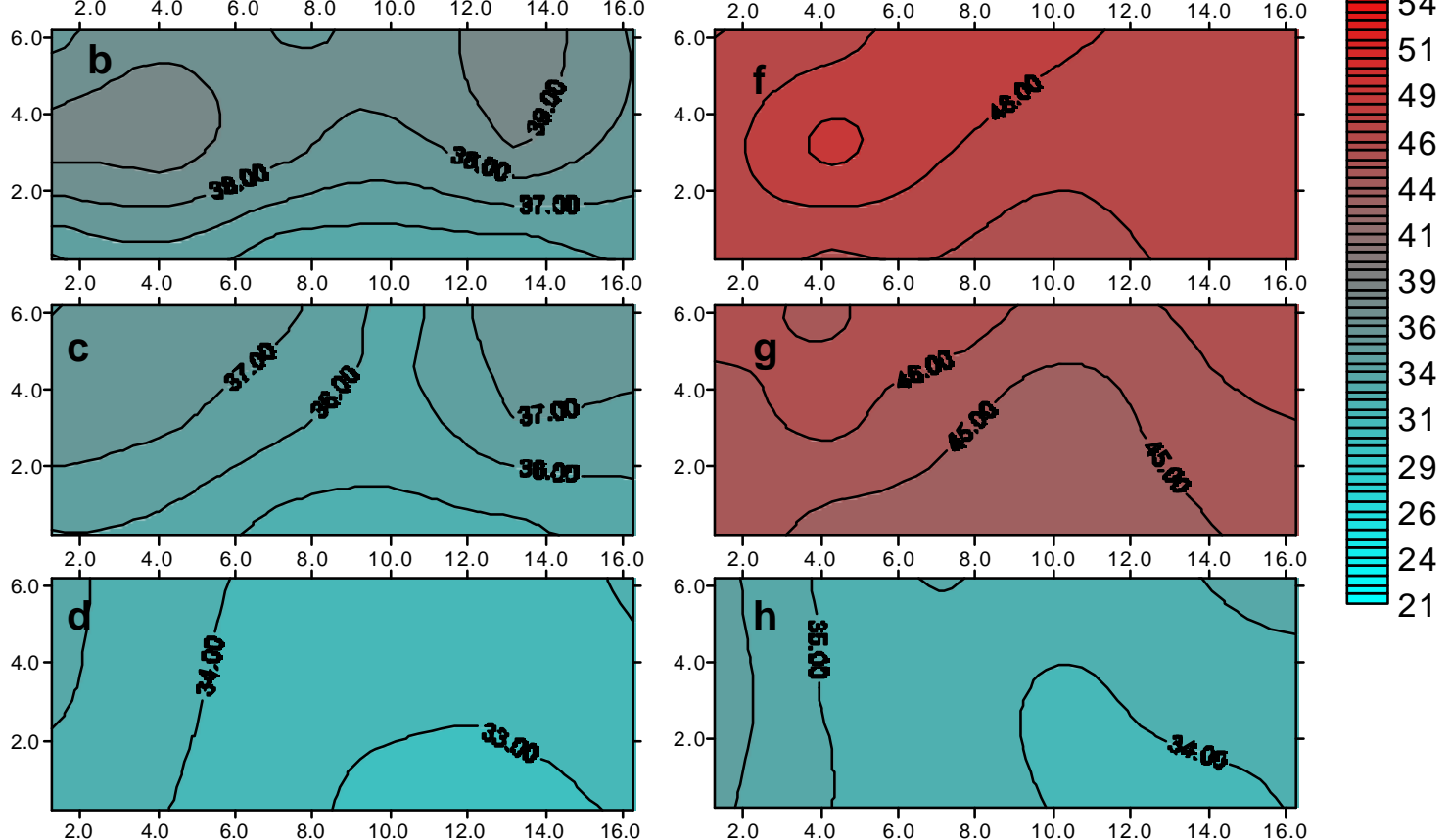

Figura 43. Distribuição de temperatura do ar no ambiente protegido com cortinas laterais abertas a $0,5 \mathrm{~m}$ de altura e abertura de cortina zenital (43a, 43b e 43c) e no ambiente protegido controle com cortinas laterais abertas a $0,5 \mathrm{~m}$ de altura (43d, 43e e 43f) para os horários de 11:00h (43a e 43e), 13:00h (43b e 43f), 15:00h (43c e 43g) e 17:00h (43d e 43h) a 2,0m de altura no dia 24/04/00. O eixo $\mathrm{x}$ representa a largura (m) e y o comprimento do ambiente protegido (m). 
Às 11:00h (Figuras 43a e 43e), a variação de temperatura do ar nos diferentes pontos de amostragem nos ambientes protegidos, não tiveram grande amplitude, com variação de 3,0 a $2,0^{\circ} \mathrm{C}$. A temperatura média do ar no perfil no ambiente protegido manejado foi de $43,4^{\circ} \mathrm{C}$ e a no ambiente protegido controle foi de $43,3^{\circ} \mathrm{C}$. Às $13: 00 \mathrm{~h}$ (Figuras 43b e 43f), a abertura da cortina zenital proporcionou maior efeito na redução de temperatura do ar quando comparado com o ambiente protegido controle. A abertura das cortinas laterais a $0,5 \mathrm{~m}$ de altura teve pouca influência na distribuição de temperatura do ar a 2,0m, não ocorrendo distribuição de temperatura do ar como ocorreu a 0,5m, evidenciando a entrada de ar externo mais frio pelas laterais dos ambientes protegidos. A essa altura, a distribuição foi mais uniforme, com menor entrada de ar pela lateral, por da ação do vento. A temperatura média do ar no perfil no ambiente protegido com abertura da cortina zenital foi de $38,0^{\circ} \mathrm{C}$, enquanto que a temperatura média do ar do perfil no ambiente protegido controle foi de $46,4^{\circ} \mathrm{C}$, ou seja, houve redução de $18,1 \%$. Ainda com a cortina zenital aberta, o perfil das 15:00h (Figuras 43c e 43f) seguiu a mesma tendência de distribuição que o das 13:00h. Nesse horário, a temperatura média do ar no perfil, com cortina zenital aberta foi de $36,6^{\circ} \mathrm{C}$, enquanto que no ambiente protegido controle foi de $44,6^{\circ} \mathrm{C}$. A redução de temperatura do ar para este perfil foi de 17,9\%. Após o fechamento da cortina zenital (17:00h), a temperatura do ar no ambiente protegido $\mathrm{E} 1$ teve variação de 33,0 a $35,0^{\circ} \mathrm{C}$, com valor médio de temperatura do ar no perfil de $33,7^{\circ} \mathrm{C}$ e no ambiente protegido controle de 34,0 a $35,0^{\circ} \mathrm{C}$, com valor médio de temperatura do ar no perfil de $34,6^{\circ} \mathrm{C}$.

$\mathrm{O}$ efeito na redução de temperatura média do ar no ambiente protegido causado pela abertura da janela zenital foi devido ao processo convectivo ou "efeito termo-sifão" descrito por Brun \& Lagier (1985). A abertura da janela zenital com cortinas laterais abertas a $0,5 \mathrm{~m}$ de altura, ocasionou o processo convectivo com a saída do ar quente pela janela zenital e entrada de ar do ambiente externo pela abertura lateral, reduzindo a temperatura média do ar no ambiente protegido, enquanto que no ambiente protegido controle, apenas com abertura das cortinas laterais a 0,5m, houve acúmulo de ar quente, principalmente acima dessa altura. Verheye \& Verlodt (1990) também obtiveram melhores resultados em ambientes protegidos equipado com abertura no teto. 
4.2.4.2. Cortinas laterais abertas a $1,0 \mathrm{~m}$ de altura.

4.2.4.2.1. Variação da temperatura do ar no ambiente protegido.

Na Figura 44 observa-se a variação da temperatura média do ar durante o dia 05/04/00 nos ambientes protegidos. Os ambientes protegidos estavam com as cortinas laterais abertas a 1,0m de altura e, portanto, sua distribuição de temperatura do ar, em equilíbrio com o ambiente externo. A maior elevação de temperatura do ar ocorreu no ambiente onde não houve abertura da cortina zenital (E2). A cortina zenital do ambiente protegido (E1) foi aberta às $11: 00 \mathrm{~h}$ e posteriormente fechada às 15:00h. Durante o período em que a cortina zenital permaneceu aberta, a temperatura média do ar foi de $39,1^{\circ} \mathrm{C}$ no ambiente testemunha e de $34,4^{\circ} \mathrm{C}$ no ambiente com abertura da cortina zenital. Houve redução da temperatura do ar de $4,7^{\circ} \mathrm{C}$, ficando o ambiente com temperatura média do ar 12,0\% abaixo da testemunha.

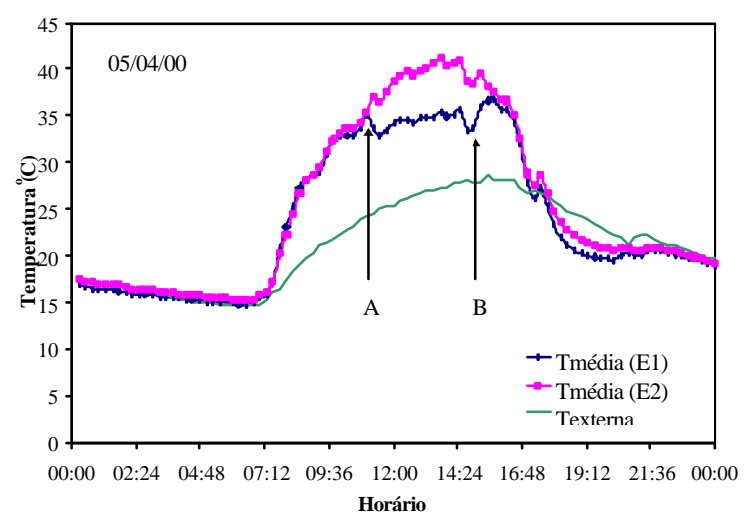

A - abertura da cortina zenital (11:00h).

B - cortina zenital fechada (15:00h).

Figura 44. Variação da temperatura média do ar no ambiente protegido com abertura da cortina zenital e cortina lateral a 1,0m (E1), no ambiente protegido controle com as cortinas laterais abertas a 1,0m (E2) e no ambiente externo, no dia 05/04/00.

A redução da temperatura do ar no ambiente protegido manejado em comparação com o ambiente controle foi significativa a 1,0\% de probabilidade pelo teste t. A temperatura média do ar externa para esse intervalo foi de $26,4^{\circ} \mathrm{C}$, ficando o 
ambiente protegido com abertura da cortina zenital com temperatura do ar 30,3\% superior a temperatura do ar externa e o ambiente testemunha, com 48,1\% acima da temperatura do ar externa.

Na Figura 45 observa-se a redução da temperatura média do ar no ambiente protegido com abertura das cortinas laterais a 1,0m e zenital (E1), em comparação com o ambiente testemunha com cortinas laterais abertas a 1,0m (E2) para o dia 08/04/00. Às 11:00h, a cortina zenital do ambiente protegido (E1) foi aberta e posteriormente fechada às 15:00h. A redução da temperatura do ar no ambiente protegido manejado em comparação com o ambiente controle foi significativa a 1,0\% de probabilidade pelo teste t. A temperatura média do ar nesse intervalo, para o ambiente testemunha (E2) foi de $41,8^{\circ} \mathrm{C}$ e a média para o ambiente com abertura da cortina zenital foi de $37,1^{\circ} \mathrm{C}$. A diferença de $4,7^{\circ} \mathrm{C}$ entre a temperatura média do ar dos ambientes protegidos, representou redução de $11,3 \%$ na temperatura média do ar no ambiente protegido com cortina zenital aberta.

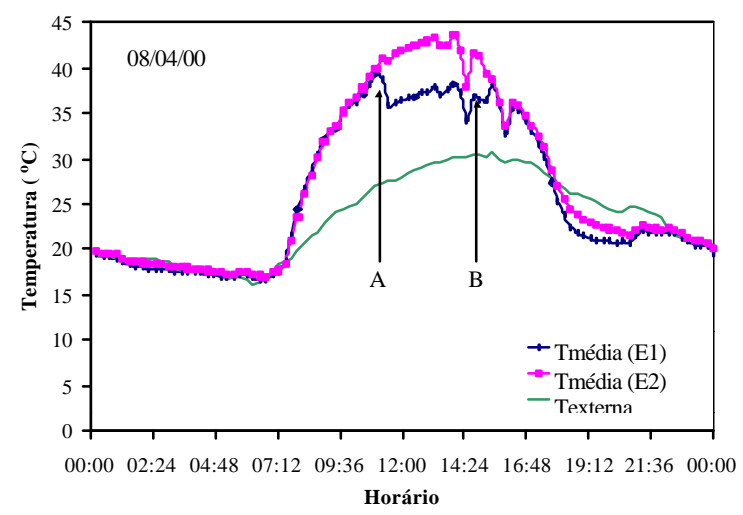

A - abertura da cortina zenital (11:00h).

B - cortina zenital fechada (15:00h).

Figura 45 Variação da temperatura média do ar no ambiente protegido com abertura da cortina zenital e cortina lateral a 1,0m (E1), no ambiente protegido controle com as cortinas laterais abertas a 1,0m (E2) e no ambiente externo, no dia 08/04/00.

A temperatura do ar externa média para esse intervalo foi de $29,0^{\circ} \mathrm{C}$, ficando o ambiente protegido com cortina zenital aberta com temperatura do ar 27,9\% superior à externa e o ambiente testemunha com 44,2\% acima da temperatura do ar externa. Nas 
Figuras 44 e 45 observa-se a variação da temperatura do ar no ambiente externo durante os dias 05 e 08/04/00.

A velocidade média do vento no ambiente externo durante o período de cortinas abertas dos ambientes protegidos foi de $1,25 \mathrm{~m} / \mathrm{s}$ e 1,0m/s para os dias 05 e 08/04/00, respectivamente, e a umidade relativa de 59,3 e 56,5\%, respectivamente.

\subsection{Variação vertical e horizontal de temperatura do ar.}

$\mathrm{Na}$ Figura 46a estão representados os perfis verticais de distribuição de temperatura média do ar no dia 08/04/00 no ambiente protegido onde houve abertura da cortina zenital com as cortinas laterais abertas a 1,0m de altura e na Figura 46b estão representados os perfis verticais de distribuição de temperatura média do ar no ambiente protegido controle com as cortinas laterais abertas a 1,0m de altura em relação ao nível do solo.
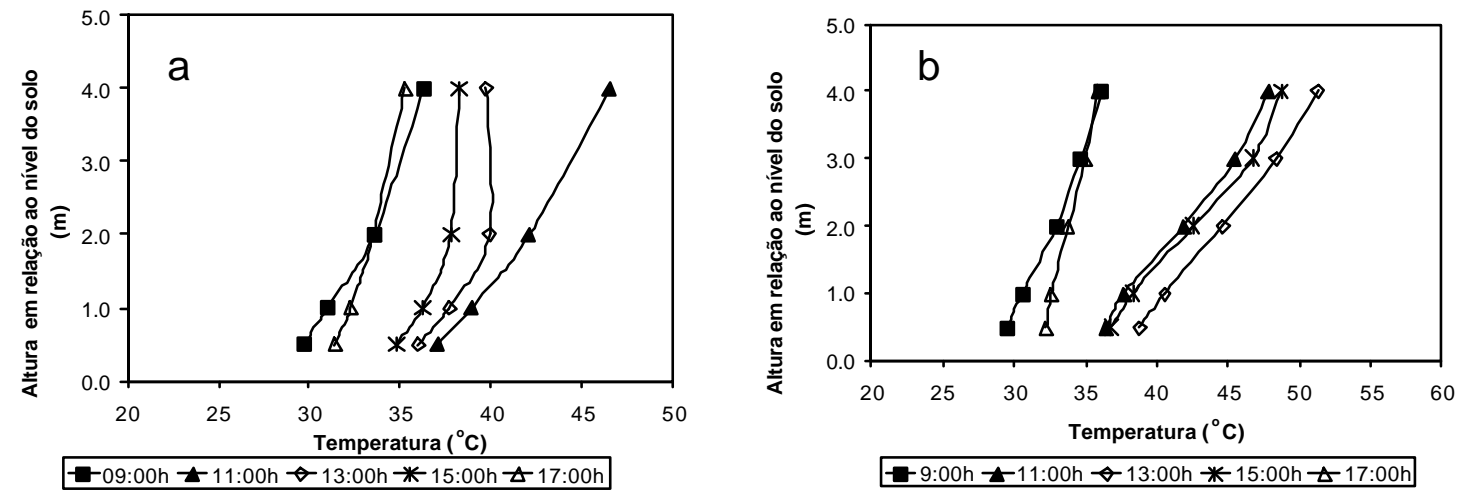

Figura 46. Perfil vertical de temperatura do ar no ambiente protegido com cortinas laterais abertas a 1,0m de altura e abertura da cortina zenital (a) e no ambiente protegido testemunha com cortinas laterais abertas a $1,0 \mathrm{~m}$ de altura (b), antes da abertura da cortina zenital (9:00h), na abertura (11:00h), durante o período em que a cortina permaneceu aberta (13:00h), no fechamento (15:00h) e após o fechamento da cortina zenital (17:00h), no dia 08/04/00. 
Às 9:00h, representa o horário anterior a abertura da cortina zenital, com as cortinas laterais abertas a 1,0m de altura. Nesse horário, os ambientes protegidos se encontravam com a mesma distribuição de temperatura do ar, chegando a $29,7^{\circ} \mathrm{C}$ ao nível de $0,5 \mathrm{~m}$ de altura no ambiente protegido cortina zenital aberta (Figura 46a) e de $29,4^{\circ} \mathrm{C}$ no ambiente protegido controle (Figura 46b) e ao nível de 4,0m de altura, temperaturas ao redor de $36,3^{\circ} \mathrm{C}$ no ambiente protegido com cortina zenital aberta e de $36,1^{\circ} \mathrm{C}$ no ambiente controle. No perfil determinado no momento da abertura da cortina zenital (11:00h) nas Figuras 46a e 46b, os ambientes protegidos apresentavam temperaturas semelhantes ao redor de $37,0^{\circ} \mathrm{C}$ a $0,5 \mathrm{~m}$ de altura e de $47^{\circ} \mathrm{C}$ a $4,0 \mathrm{~m}$ de altura, com média de temperatura do ar no perfil de $41,4^{\circ} \mathrm{C}$. Nos perfis verticais determinados antes da abertura da cortina zenital, observou-se o aumento da temperatura média do ar com o aumento na altura de coleta de dados, nos ambientes protegidos, chegando a temperatura do ar máxima a 4,0m, no ponto mais alto do ambiente protegido e próximo da cobertura plástica. A abertura de $1,0 \mathrm{~m}$ de altura das cortinas laterais teve efeito na redução de temperatura do ar em todo o perfil, não evidenciando efeito somente nas alturas de 0,5 e $1,0 \mathrm{~m}$. $\mathrm{O}$ efeito, entretanto, foi maior nas laterais a $0,5 \mathrm{~m}$ de altura dos ambientes protegidos, determinado através das isotermas (Figura 47). Após abertura da cortina zenital às 13:00h, no ambiente protegido com cortina zenital aberta em comparação com o ambiente protegido controle, observou-se o efeito da redução de temperatura média do ar pela abertura da cortina zenital e diminuição do gradiente de temperatura do ar a partir de 1,0m de altura em relação ao nível do solo, proporcionando uma temperatura média do ar homogênea no perfil principalmente de $2,0 \mathrm{~m}$ a $4,0 \mathrm{~m}$. As temperaturas médias do ar a $2,0 \mathrm{~m}$ e a $4,0 \mathrm{~m}$ tiveram variação de $0,2^{\circ} \mathrm{C}$. Entretanto, no ambiente protegido controle a temperatura do ar se elevou à medida que houve elevação na altura analisada. A temperatura média do ar no perfil vertical no ambiente protegido com cortina zenital aberta foi de $38,3^{\circ} \mathrm{C}$, com temperatura média do ar de $36,0^{\circ} \mathrm{C}$ a $0,5 \mathrm{~m}$ e de $39,7^{\circ} \mathrm{C}$ a $4,0 \mathrm{~m}$ de altura, enquanto que a temperatura média do ar no perfil no ambiente protegido controle foi de $44,7^{\circ} \mathrm{C}$, com temperatura média do ar de $38,8^{\circ} \mathrm{C}$ a $0,5 \mathrm{~m}$ e de $51,3^{\circ} \mathrm{C}$ a $4,0 \mathrm{~m}$ de altura. A abertura da cortina zenital nesse horário proporcionou uma redução de temperatura média do ar no perfil de 14,3\%. No perfil correspondente às 15:00h, obtivemos a mesma tendência de distribuição vertical de 
temperatura do ar observada no perfil das 13:00h. A temperatura média do ar no perfil vertical no ambiente protegido com cortina zenital aberta foi de $36,7^{\circ} \mathrm{C}$, com temperatura média do ar de $34,7^{\circ} \mathrm{C}$ a $0,5 \mathrm{~m}$ e de $38,3^{\circ} \mathrm{C}$ a $4,0 \mathrm{~m}$ de altura e a temperatura média do ar no perfil vertical no ambiente protegido controle foi de $42,6^{\circ} \mathrm{C}$, com temperatura média do ar de $36,9^{\circ} \mathrm{C}$ a $0,5 \mathrm{~m}$ e $48,7^{\circ} \mathrm{C}$ a $4,0 \mathrm{~m}$, representando uma redução média de temperatura de $13,8 \%$. No ambiente protegido com cortina zenital aberta, a variação de temperatura do ar entre a temperatura média do ar obtida a $2,0 \mathrm{~m}$ e a obtida a $4,0 \mathrm{~m}$ foi e $0,5^{\circ} \mathrm{C}$. Nos ambientes protegidos, os perfis correspondentes às 17:00h, a distribuição de temperatura do ar foram semelhantes. A temperatura média do ar no perfil vertical no ambiente protegido (E1) foi de $33,1^{\circ} \mathrm{C}$, com temperatura média do ar de $31,4^{\circ} \mathrm{C}$ a $0,5 \mathrm{~m}$ e de $35,3^{\circ} \mathrm{C}$ a $4,0 \mathrm{~m}$ de altura e a temperatura média do ar no perfil vertical no ambiente protegido controle foi de $33,9^{\circ} \mathrm{C}$, com temperatura média do ar de $32,2^{\circ} \mathrm{C}$ a $0,5 \mathrm{~m}$ e $35,8^{\circ} \mathrm{C}$ a $4,0 \mathrm{~m}$, representando redução média de temperatura do ar de $2,4 \%$.

$\mathrm{Na}$ Figura 47 estão representas as isotermas a 0,5m de altura no dia 08/04/00 para o ambiente protegido com cortinas laterais abertas a $1,0 \mathrm{~m}$ e abertura de cortina zenital $(47 \mathrm{a}, 47 \mathrm{~b}$ e $47 \mathrm{c})$ e o ambiente protegido controle com cortinas laterais abertas a 1,0m de altura (47d, 47e e 47f) para os horários de 11:00h (47a e 47e), 13:00h (47b e 47f), 15:00h (47c e 47g) e 17:00h (47d e 47h).

Às 11:00h (Figuras 47a e 47e) a variação de temperatura do ar nos ambientes protegidos foi de $1,0^{\circ} \mathrm{C}$, com temperaturas menores nas laterais e temperaturas maiores no centro do ambiente protegido por estarem as cortinas laterais abertas a 1,0m de altura em relação ao nível do solo. Nesse horário a velocidade do vento foi de $0,8 \mathrm{~m} / \mathrm{s}$, sudoeste. A temperatura média do ar no perfil horizontal foi de 35,4 e $35,1^{\circ} \mathrm{C}$ para o ambiente protegido com cortina zenital aberta e testemunha, respectivamente.

Às 13:00h, com a cortina zenital aberta (Figura 47b) a temperatura do ar no ambiente protegido não teve distribuição regular, enquanto que no ambiente protegido testemunha houve distribuição com a mesma tendência da ocorrida às 11:00h, com temperaturas menores nas laterais e maiores no centro e próximas às paredes que formam a largura do ambiente protegido, por serem fechadas com plástico e não terem cortinas removíveis (Figura 47f). A temperatura média do ar no perfil no ambiente 
protegido com cortina zenital aberta foi de $35,9^{\circ} \mathrm{C}$, enquanto que a temperatura média do ar no perfil no ambiente protegido controle foi de $37,8^{\circ} \mathrm{C}$. Nessa situação, a abertura da janela zenital reduziu a temperatura média do ar no perfil em 5,0\%. A velocidade do vento média às $13: 00 \mathrm{~h}$ foi de $1,3 \mathrm{~m} / \mathrm{s}$, na direção nordeste.
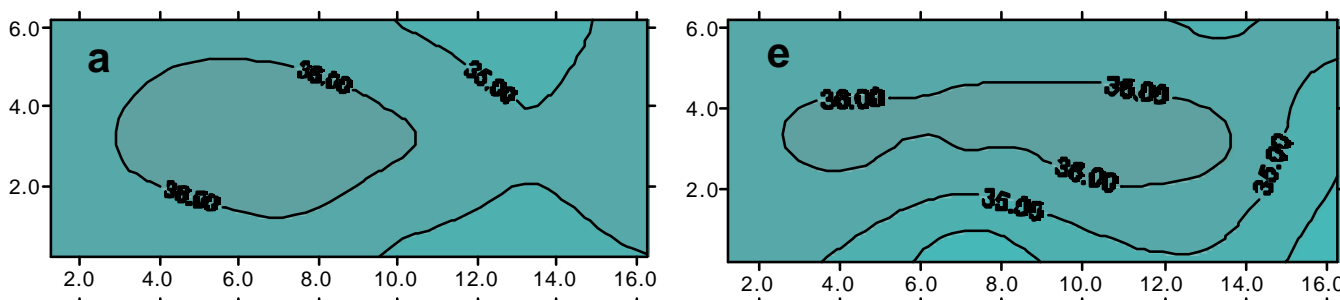

$\left({ }^{\circ} \mathrm{C}\right)$
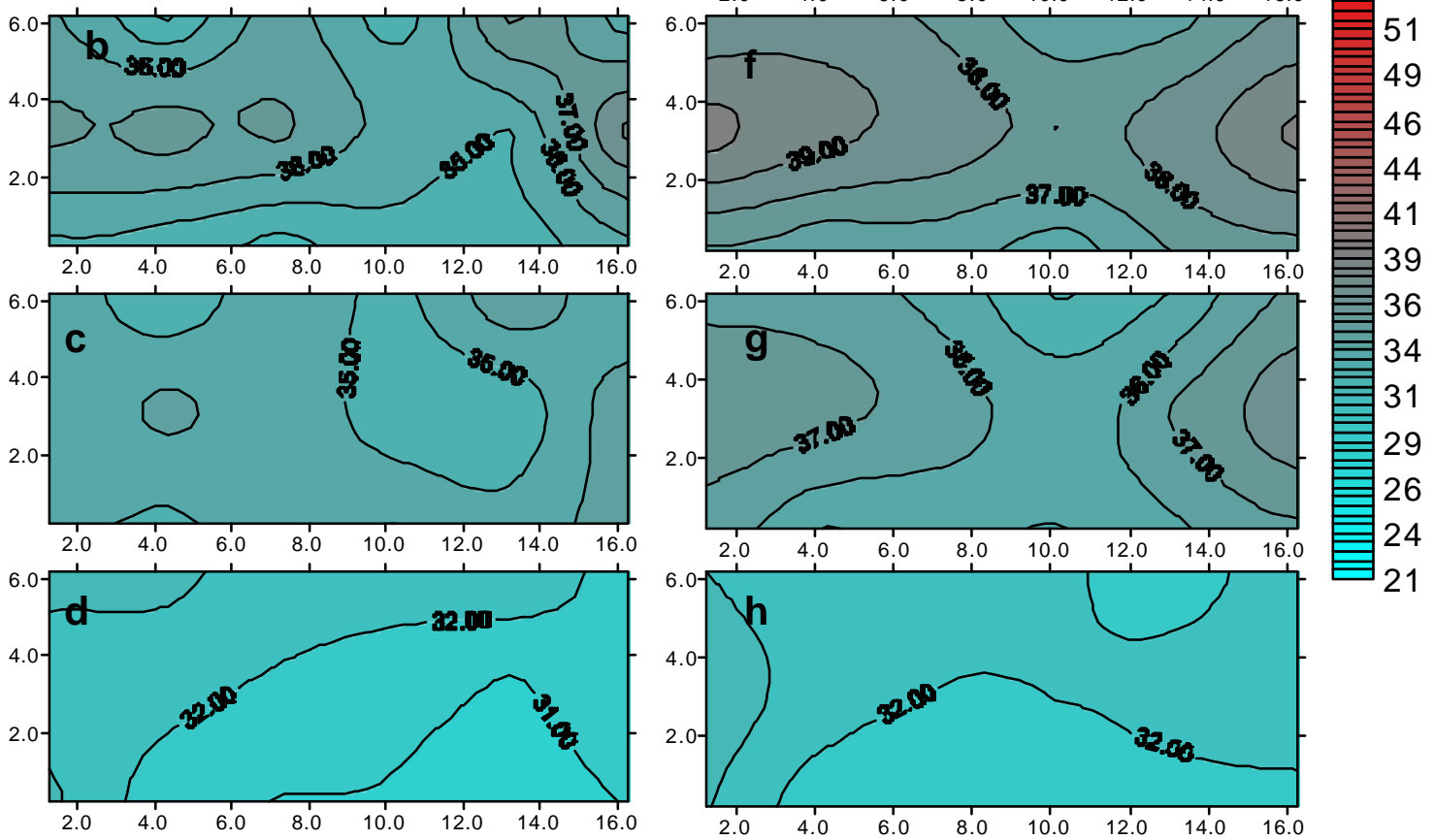

Figura 47. Distribuição de temperatura do ar no ambiente protegido com cortinas laterais abertas a 1,0m e abertura de cortina zenital (47a, 47b e 47c) e no ambiente protegido controle com cortinas laterais abertas a 1,0m de altura $(47 \mathrm{~d}, 47 \mathrm{e}$ e 47f) para os horários de 11:00h (47a e 47e), 13:00h (47b e 47f), 15:00h (47c e 47g) e 17:00h (47d e 47h) a 0,5m de altura no dia 08/04/00. O eixo x representa a largura (m) e y o comprimento do ambiente protegido (m).

No momento do fechamento da cortina zenital (15:00h), a distribuição de temperatura do ar nos ambientes protegidos permaneceram a mesma, porém, com 
temperaturas médias do ar de 35,6 e $36,3^{\circ} \mathrm{C}$, para o ambiente com cortina zenital aberta (Figura 47c) e testemunha (Figura 47g), respectivamente, havendo redução de 1,9\%. A velocidade do vento nesse período foi de $1,7 \mathrm{~m} / \mathrm{s}$ na direção sudoeste. Nas Figuras $47 \mathrm{~d}$ e 47h (às 17:00h) estão representadas as distribuições horizontais de temperatura do ar no ambiente protegido após o fechamento da cortina zenital. A distribuição de temperatura do ar no ambiente protegido com abertura de cortina zenital (Figura 47d) teve temperaturas um pouco inferiores a do ambiente protegido controle (Figura 47h) com temperatura média do ar no perfil de $31,9^{\circ} \mathrm{C}$ e $32,2^{\circ} \mathrm{C}$ respectivamente, ou seja, $0,9 \%$.

Na Figura 48 estão representadas as isotermas a 2,0m de altura no dia 08/04/00 para o ambiente protegido com cortinas laterais abertas a 1,0m de altura e abertura de cortina zenital (48a, 48b e 48c) e o ambiente protegido controle com cortinas laterais abertas a 1,0m de altura (48d, 48e e 48f) para os horários de 11:00h (48a e 48e), 13:00h (48b e 48f), 15:00h (48c e 48g) e 17:00h (48d e 48h).

Às 11:00h (Figuras 48a e 48e) a variação de temperatura do ar nos diferentes pontos de amostragem nos ambientes protegidos, foi de 1,0 a $2,0^{\circ} \mathrm{C}$. A temperatura média do ar no perfil no ambiente protegido com cortina zenital aberta foi de $41,1^{\circ} \mathrm{C}$ e a no ambiente protegido controle foi de $40,8^{\circ} \mathrm{C}$. Às 13:00h (Figuras $48 \mathrm{~b}$ e $48 \mathrm{f}$ ), a abertura da cortina zenital proporcionou redução de temperatura do ar no ambiente protegido com cortina zenital aberta quando comparado com o ambiente protegido controle. A abertura das cortinas laterais a $1,0 \mathrm{~m}$ de altura teve influência na distribuição de temperatura do ar a 2,0m como ocorreu a $0,5 \mathrm{~m}$. A temperatura média do ar no perfil no ambiente protegido com abertura da cortina zenital foi de $38,6^{\circ} \mathrm{C}$, enquanto que a temperatura média do ar no perfil no ambiente protegido controle foi de $43,4^{\circ} \mathrm{C}$, ou seja, houve redução de 11,1\%. Ainda com a cortina zenital aberta, o perfil das 15:00h (Figuras 48c e 48f) seguiu a mesma tendência de distribuição que às 13:00h, porém, com maior influência da ação do vento, conforme visto no perfil de $0,5 \mathrm{~m}$ de altura. Nesse horário, a temperatura média do ar no perfil, com cortina zenital aberta foi de $37,3^{\circ} \mathrm{C}$, enquanto que no ambiente protegido controle foi de $41,8^{\circ} \mathrm{C}$. A redução de temperatura para este perfil foi de 10,8\%. Após o fechamento da cortina zenital (Figuras 48d e 48h), a temperatura do ar no ambiente protegido com a cortina zenital aberta teve variação de 
33,0 a $35,0^{\circ} \mathrm{C}$, com valor médio de temperatura do ar no perfil de $33,8^{\circ} \mathrm{C}$ e no ambiente protegido controle de 34,0 a $35,0^{\circ} \mathrm{C}$, com valor médio de temperatura do ar no perfil de $34,0^{\circ} \mathrm{C}$.
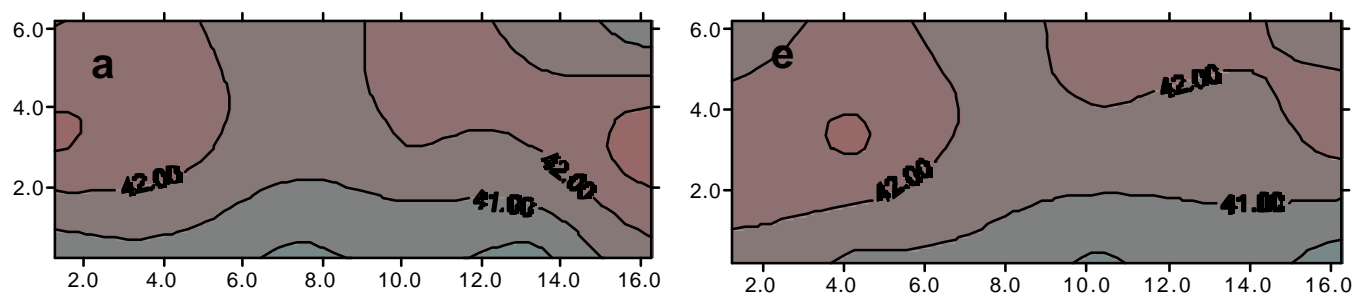

$\left({ }^{\circ} \mathrm{C}\right)$
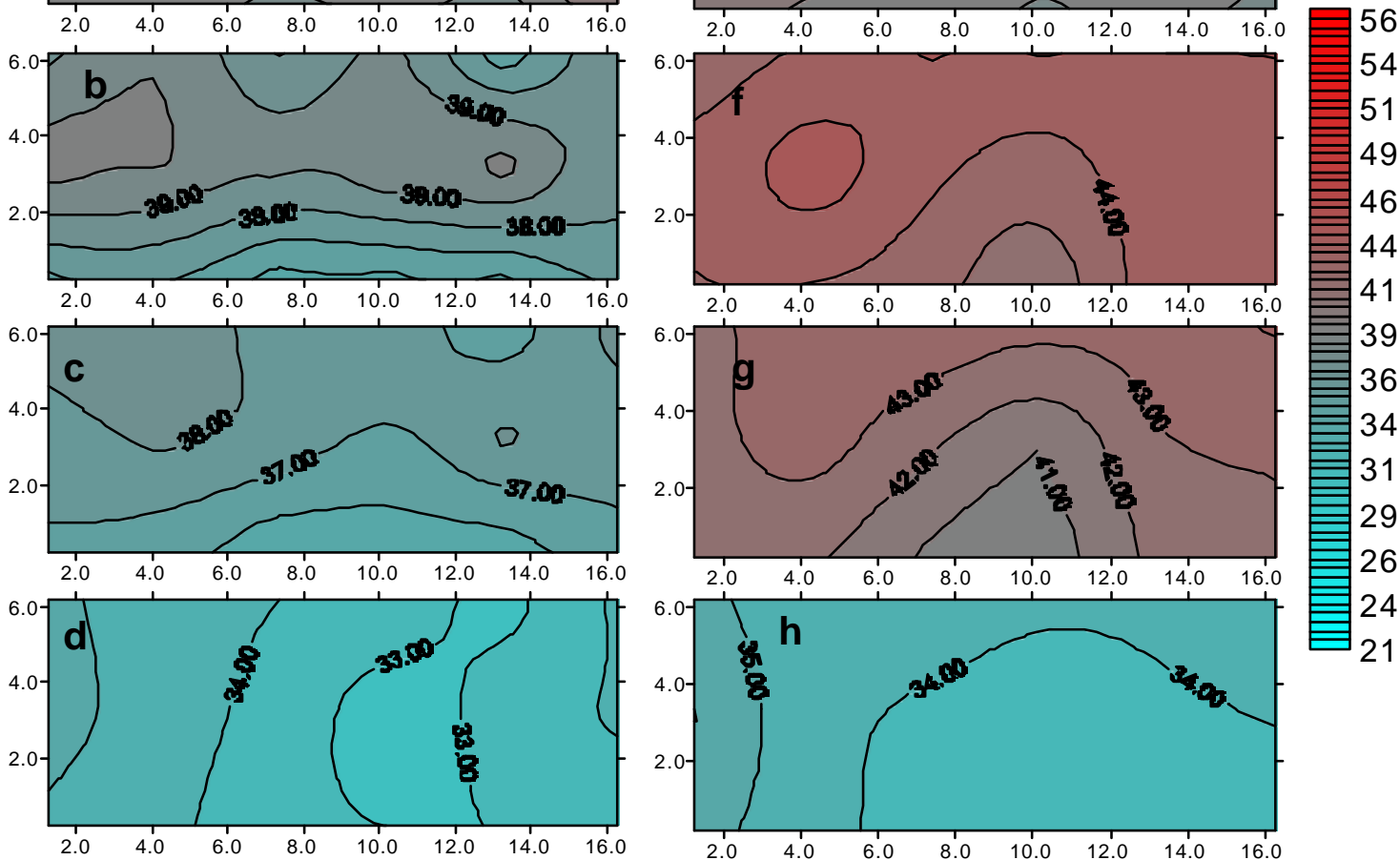

Figura 48. Distribuição de temperatura do ar no ambiente protegido com cortinas laterais abertas a $1,0 \mathrm{~m}$ de altura e abertura de cortina zenital (48a, 48b e 48c) e no ambiente protegido controle com cortinas laterais abertas a $1,0 \mathrm{~m}$ de altura (48d, 48e e 48f) para os horários de 11:00h (48a e 48e), 13:00h (48b e 48f), 15:00h (48c e 48g) e 17:00h (48d e 48h) a 2,0m de altura no dia 08/04/00. O eixo $\mathrm{x}$ representa a largura $(\mathrm{m})$ e $\mathrm{y}$ o comprimento do ambiente protegido (m). 
4.2.4.3. Cortinas laterais abertas a $2,0 \mathrm{~m}$ de altura.

\subsection{Variação da temperatura do ar no ambiente protegido.}

Mantendo-se os ambientes protegidos com as cortinas laterais abertas a 2,0m de altura, comparou-se a variação de temperatura média do ar no ambiente protegido controle e no ambiente protegido com abertura da cortina zenital. Na Figura 49 observase a redução da temperatura média do ar no ambiente protegido (E1) onde a cortina zenital foi aberta, em comparação com o ambiente testemunha (E2) para o dia 12/04/00. A redução da temperatura do ar no ambiente protegido manejado em comparação com o ambiente controle foi significativa a 1,0\% de probabilidade pelo teste t. Às 11:00h, a cortina zenital do ambiente protegido foi totalmente aberta, sendo fechada posteriormente às 15:00h. A temperatura média do ar nesse intervalo, para o ambiente cortina zenital aberta foi de $37,0^{\circ} \mathrm{C}$ e a média para o ambiente controle foi de $38,8^{\circ} \mathrm{C}$. A diferença de $1,8^{\circ} \mathrm{C}$ resultou numa redução da temperatura média do ar de 4,6\% na temperatura média do ar no ambiente com cortina zenital aberta em relação ao ambiente controle.

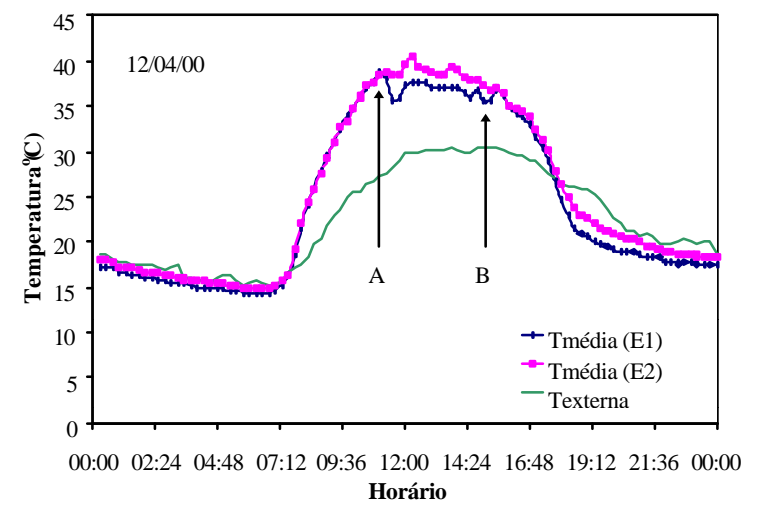

A - abertura da cortina zenital (11:00h).

B - cortina zenital fechada (15:00h).

Figura 49. Variação da temperatura média do ar no ambiente protegido com abertura da cortina zenital e cortina lateral a 2,0m (E1), no ambiente protegido controle com as cortinas laterais abertas a 2,0m (E2) e no ambiente externo, no dia $12 / 04 / 00$. 
A temperatura média do ar no ambiente externo para esse intervalo foi de $29,6^{\circ} \mathrm{C}$, ficando o ambiente protegido com cortina zenital aberta com temperatura do ar $24,9 \%$ superior à externa e o ambiente testemunha com 30,9\% acima da mesma.

Na Figura 50, observa-se a redução da temperatura média do ar no ambiente protegido com abertura da cortina zenital (E1) em comparação com o ambiente controle (E2) no dia 15/04/00. A cortina zenital foi aberta às 11:00h e fechada às 15:00h. A redução da temperatura do ar no ambiente protegido manejado em comparação com o ambiente controle foi significativa a 1,0\% de probabilidade pelo teste t. A temperatura média do ar nesse intervalo para o ambiente testemunha foi de $38,1^{\circ} \mathrm{C}$ e a média para $\mathrm{o}$ ambiente protegido com cortina zenital aberta foi de $35,9^{\circ} \mathrm{C}$. A diferença de $2,2^{\circ} \mathrm{C}$ representa redução da temperatura média do ar no ambiente protegido com abertura da cortina zenital de 5,8\%. A temperatura média do ar externa para este intervalo foi de $28,4^{\circ} \mathrm{C}$, ficando o ambiente protegido com cortina zenital aberta com temperatura do ar $26,3 \%$ superior à temperatura do ar externa e o ambiente controle, com 34,1\% acima da temperatura do ar externa.

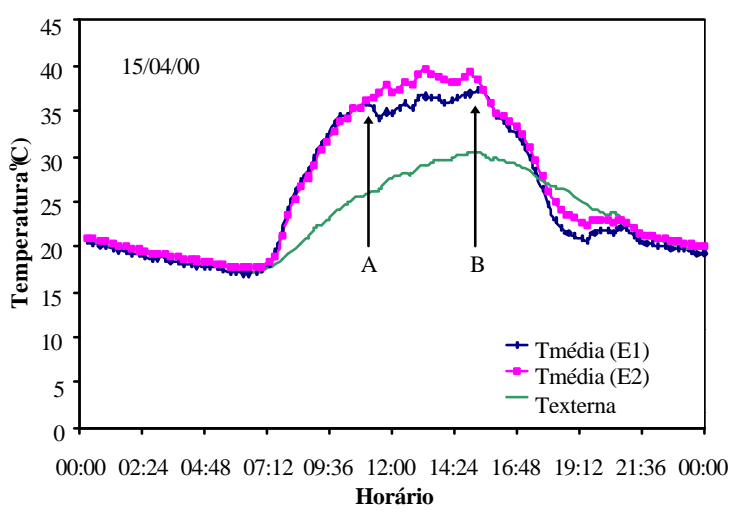

A - abertura da cortina zenital (11:00h).

B - cortina zenital fechada (15:00h).

Figura 50. Variação da temperatura média do ar no ambiente protegido com abertura da cortina zenital e cortina lateral a 2,0m (E1), no ambiente protegido controle com as cortinas laterais abertas a 2,0m (E2) e no ambiente externo, no dia $15 / 04 / 00$.

A velocidade média do vento para os dias 12 e 15/04/00 foi de 1,4m/s e $0,8 \mathrm{~m} / \mathrm{s}$, respectivamente, enquanto que a umidade relativa foi de 53,8\% e $63,8 \%$. 
4.2.4.3.2. Variação vertical e horizontal de temperatura do ar.

$\mathrm{Na}$ Figura 51a estão representados os perfis verticais de distribuição de temperatura média do ar no dia 15/04/00 no ambiente protegido onde houve abertura da cortina zenital com as cortinas laterais abertas a 2,0m de altura e na Figura 51 b estão representados os perfis verticais de distribuição de temperatura média do ar no ambiente protegido controle com as cortinas laterais abertas a 2,0m de altura em relação ao nível do solo.
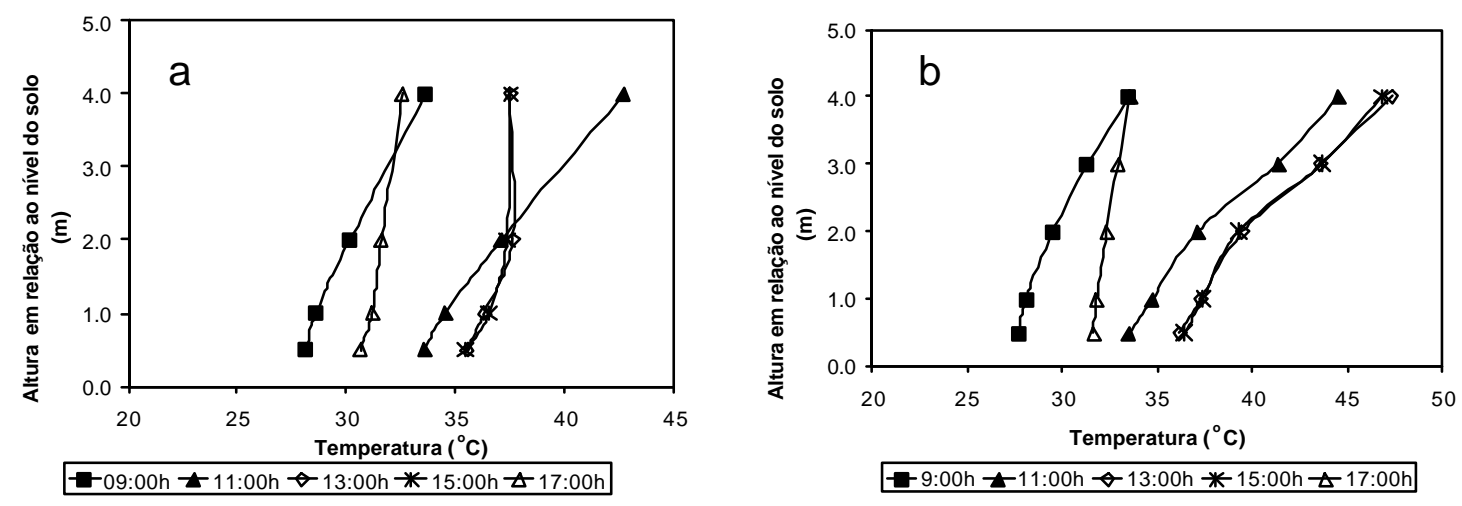

Figura 51. Perfil vertical de temperatura do ar no ambiente protegido com cortinas laterais abertas a 2,0m de altura e abertura da cortina zenital (a) e no ambiente protegido testemunha com cortinas laterais abertas a 2,0m de altura (b), antes da abertura da cortina zenital (9:00h), na abertura (11:00h), durante o período em que a cortina permaneceu aberta (13:00h), no fechamento (15:00h) e após o fechamento da cortina zenital (17:00h), no dia 15/04/00.

Às 9:00h, representa o horário anterior a abertura da cortina zenital, com as cortinas laterais abertas a 2,0m de altura. Nesse horário, os ambientes protegidos se encontravam praticamente com a mesma distribuição de temperatura do ar, chegando a $28,0^{\circ} \mathrm{C}$ ao nível de $0,5 \mathrm{~m}$ de altura no ambiente protegido com cortina zenital aberta (Figura $59 \mathrm{a}$ ) e de $27,8^{\circ} \mathrm{C}$ no ambiente protegido controle (Figura 59b) e ao nível de 4,0m de altura, temperaturas ao redor de $33,6^{\circ} \mathrm{C}$ no ambiente protegido com cortina zenital aberta e de $33,5^{\circ} \mathrm{C}$ no ambiente controle, com temperatura média do ar no perfil de 30,0 e $30,1^{\circ} \mathrm{C}$, 
respectivamente. No perfil determinado no momento da abertura da cortina zenital (11:00h), os ambientes protegidos apresentavam temperaturas semelhantes ao redor de $33,5^{\circ} \mathrm{C}$ a $0,5 \mathrm{~m}$ de altura e $45,5^{\circ} \mathrm{C}$ a $4,0 \mathrm{~m}$ de altura, com média de temperatura do ar no perfil de $38,0^{\circ} \mathrm{C}$. Nos perfis verticais determinados antes da abertura da cortina zenital, observou-se o aumento da temperatura média do ar com o aumento na altura de coleta de dados, nos ambientes protegidos, chegando a temperatura do ar máxima a 4,0m, no ponto mais alto do ambiente protegido e próximo da cobertura plástica. A abertura de 2,0m de altura das cortinas laterais teve efeito na redução de temperatura do ar evidenciando maior efeito nas alturas entre 0,5 e 2,0m, com maior efeito nas laterais dos ambientes protegidos, determinado através das isotermas (Figuras 52 e 53). Após abertura da cortina zenital às 13:00h, no ambiente protegido com cortina zenital aberta em comparação com o ambiente protegido controle, observou-se o efeito da redução de temperatura média do ar pela abertura da cortina zenital e diminuição do gradiente de temperatura a partir de $2,0 \mathrm{~m}$ de altura em relação ao nível do solo, proporcionando uma temperatura média do ar homogênea no perfil principalmente de 2,0m a 4,0m. As temperaturas médias do ar a 2,0m e a $4,0 \mathrm{~m}$ tiveram variação de $0,1^{\circ} \mathrm{C}$, com temperatura do ar média de $37,6^{\circ} \mathrm{C}$ a $2,0 \mathrm{~m}$ e $37,5^{\circ} \mathrm{C}$ a $4,0 \mathrm{~m}$ de altura. Entretanto, no ambiente protegido controle a temperatura do ar se elevou à medida que houve elevação na altura analisada, acentuando o gradiente de temperatura do ar a partir de 2,0m de altura, devido a abertura da cortina lateral a $2,0 \mathrm{~m}$. A temperatura média do ar no perfil vertical no ambiente protegido com cortina zenital aberta foi de $36,7^{\circ} \mathrm{C}$, com temperatura média do ar de $35,5^{\circ} \mathrm{C}$ a $0,5 \mathrm{~m}$ e de $37,5^{\circ} \mathrm{C}$ a $4,0 \mathrm{~m}$ de altura, enquanto que a temperatura média do ar no perfil no ambiente protegido controle foi de $40,7^{\circ} \mathrm{C}$, com temperatura média do ar de $36,2^{\circ} \mathrm{C}$ a $0,5 \mathrm{~m}$ e de $47,3^{\circ} \mathrm{C}$ a $4,0 \mathrm{~m}$ de altura. A abertura da cortina zenital nesse horário proporcionou uma redução de temperatura média do ar no perfil 9,8\%. No perfil correspondente às 15:00h, obtivemos a mesma distribuição vertical de temperatura do ar observada no perfil das 13:00h. A temperatura média do ar no perfil vertical no ambiente protegido com cortina zenital aberta foi de $36,7^{\circ} \mathrm{C}$, com temperatura média do ar de $35,5^{\circ} \mathrm{C}$ a $0,5 \mathrm{~m}$ e de $37,5^{\circ} \mathrm{C}$ a $4,0 \mathrm{~m}$ de altura e a temperatura média do ar no perfil vertical no ambiente protegido controle foi de $40,7^{\circ} \mathrm{C}$, com temperatura média do ar de $36,4^{\circ} \mathrm{C}$ a $0,5 \mathrm{~m}$ e $46,7^{\circ} \mathrm{C}$ a $4,0 \mathrm{~m}$, representando redução média 
de temperatura do ar de 9,8\%. No ambiente protegido com cortina zenital aberta, a variação de temperatura entre a obtida a $2,0 \mathrm{~m}$ e a obtida a $4,0 \mathrm{~m}$ foi e $0,2^{\circ} \mathrm{C}$. Nos ambientes protegidos, os perfis correspondentes às 17:00h, a distribuição de temperatura do ar foram semelhantes nos ambientes protegidos, ficando o ambiente protegido controle com $1,0^{\circ} \mathrm{C}$ a mais. A temperatura média do ar no perfil vertical no ambiente protegido com cortina zenital aberta foi de $31,5^{\circ} \mathrm{C}$, com temperatura média do ar de $30,6^{\circ} \mathrm{C}$ a $0,5 \mathrm{~m}$ e de $32,6^{\circ} \mathrm{C}$ a $4,0 \mathrm{~m}$ de altura e a temperatura média do ar no perfil vertical no ambiente protegido controle foi de $32,4^{\circ} \mathrm{C}$, com temperatura média do ar de $31,6^{\circ} \mathrm{C}$ a $0,5 \mathrm{~m}$ e $33,6^{\circ} \mathrm{C}$ a $4,0 \mathrm{~m}$, reduzindo a temperatura do ar de $2,8 \%$.

Na Figura 52 estão representadas as isotermas a 0,5m de altura no dia 15/04/00 para o ambiente protegido com cortinas laterais abertas a 2,0m e abertura de cortina zenital (52a, 52b e 52c) e no ambiente protegido controle com cortinas laterais abertas a 2,0m de altura (52d, 52e e 52f) para os horários de 11:00h (52a e 52e), 13:00h (52b e 52f), 15:00h (52c e 52g) e 17:00h (52d e 52h).

Às 11:00h (Figuras 52a e 52e) a variação de temperatura do ar nos ambientes protegidos foi de $2,0^{\circ} \mathrm{C}$, com temperaturas menores nas laterais. Nesse horário a velocidade do vento foi de $0,2 \mathrm{~m} / \mathrm{s}$, sudeste. A temperatura média do ar no perfil horizontal foi de 33,2 e $32,9^{\circ} \mathrm{C}$ para o ambiente protegido com cortina zenital aberta e testemunha, respectivamente.

Às 13:00h, com a cortina zenital aberta (Figura 52b), a temperatura do ar no ambiente protegido não teve distribuição regular, com área de menor temperatura do ar central, enquanto que no ambiente protegido testemunha houve distribuição evidenciando a entrada de ar lateral, com concentração de temperaturas maiores nos extremos do ambiente protegido cujas laterais eram construídas com plástico não removível (paredes que formam a largura do ambiente protegido) (Figura 52f). A temperatura média do ar no perfil no ambiente protegido com cortina zenital aberta foi de $36,9^{\circ} \mathrm{C}$, enquanto que a temperatura média do ar no perfil no ambiente protegido controle foi de $36,8^{\circ} \mathrm{C}$. Nessa situação, a abertura da janela zenital reduziu a temperatura média do ar no perfil a $0,5 \mathrm{~m}$ de altura. A velocidade do vento média às 13:00h foi de $0,31 \mathrm{~m} / \mathrm{s}$ na direção sudeste. 

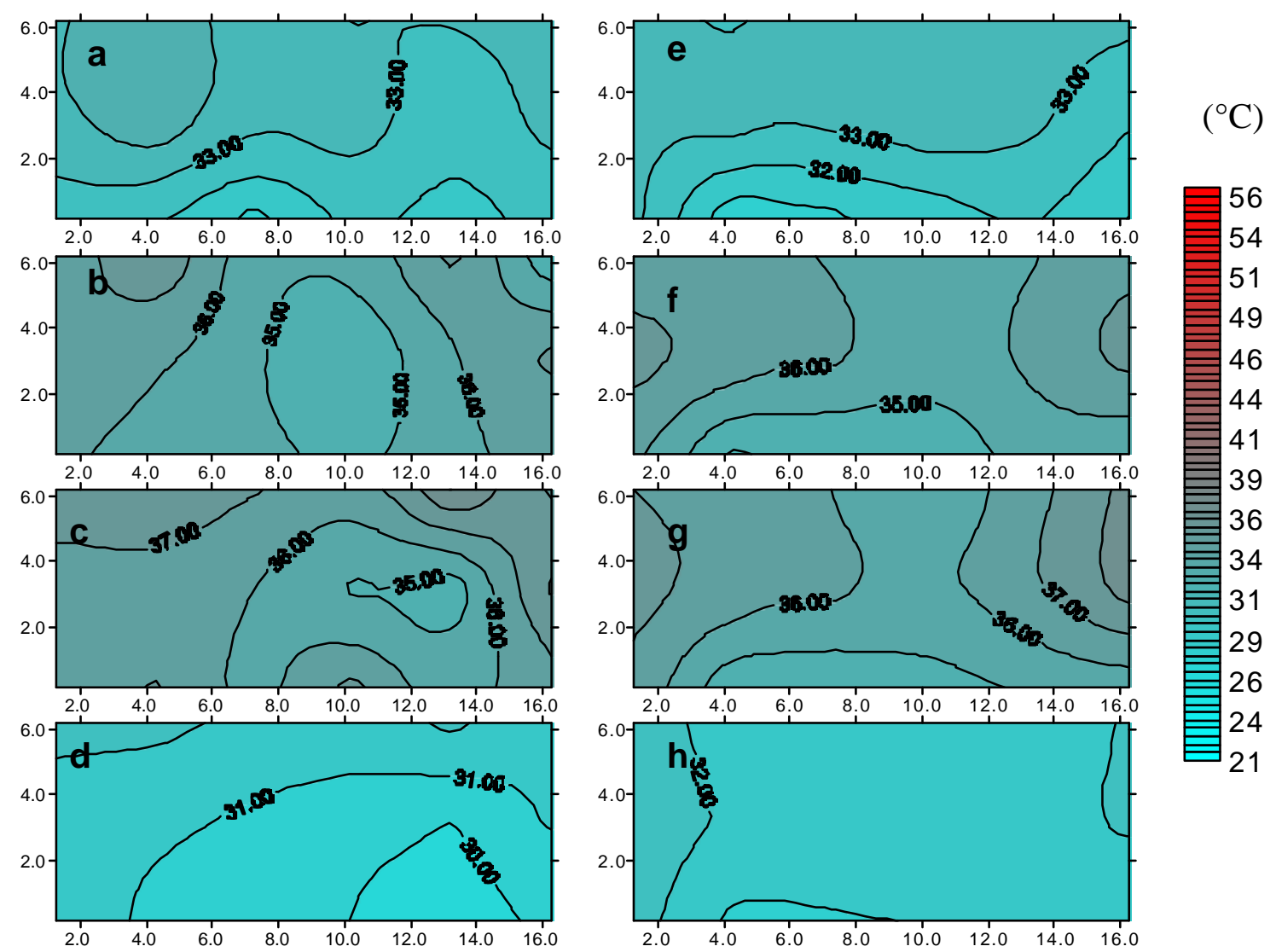

Figura 52. Distribuição de temperatura do ar no ambiente protegido com cortinas laterais abertas a 2,0m e abertura de cortina zenital (52a, 52b e 52c) e no ambiente protegido controle com cortinas laterais abertas a 2,0m de altura $(52 \mathrm{~d}, 52 \mathrm{e}$ e 52f) para os horários de 11:00h (52a e 52e), 13:00h (52b e 52f), 15:00h (52c e 52g) e 17:00h (52d e 52h) a 0,5m de altura no dia 15/04/00. O eixo x representa a largura (m) e y o comprimento do ambiente protegido (m).

No momento do fechamento da cortina zenital (15:00h), a distribuição de temperatura do ar nos ambientes protegidos permaneceu a mesma, porém com temperaturas médias do ar de 36,2 e $36,7^{\circ} \mathrm{C}$, para o ambiente com cortina zenital aberta (Figura 52c) e testemunha (Figura 52g), respectivamente, com redução de 1,4\%. A velocidade do vento nesse período foi de 0,97m/s, na direção sudoeste. Nas Figuras 52d e 52h (às 17:00h) estão representadas as distribuições horizontais de temperatura do ar no ambiente protegido após o fechamento da cortina zenital. A distribuição de temperatura do ar no ambiente protegido com abertura de cortina zenital (Figura 52d) 
teve temperaturas um pouco inferiores a do ambiente protegido controle (Figura 52h) com temperatura média do ar no perfil de $31,1^{\circ} \mathrm{C}$ e $31,6^{\circ} \mathrm{C}$ respectivamente, ou seja, $1,6 \%$ inferior.

Na Figura 53 estão representadas as isotermas a 2,0m de no dia 15/04/00 para o ambiente protegido com cortinas laterais abertas a 2,0m e altura e abertura de cortina zenital (53a, 53b e 53c) e o ambiente protegido controle com cortinas laterais abertas a 2,0m de altura (53d, 53e e 53f) para os horários de 11:00h (53a e 53e), 13:00h (53b e 53f), 15:00h (53c e 53g) e 17:00h (53d e 53h).
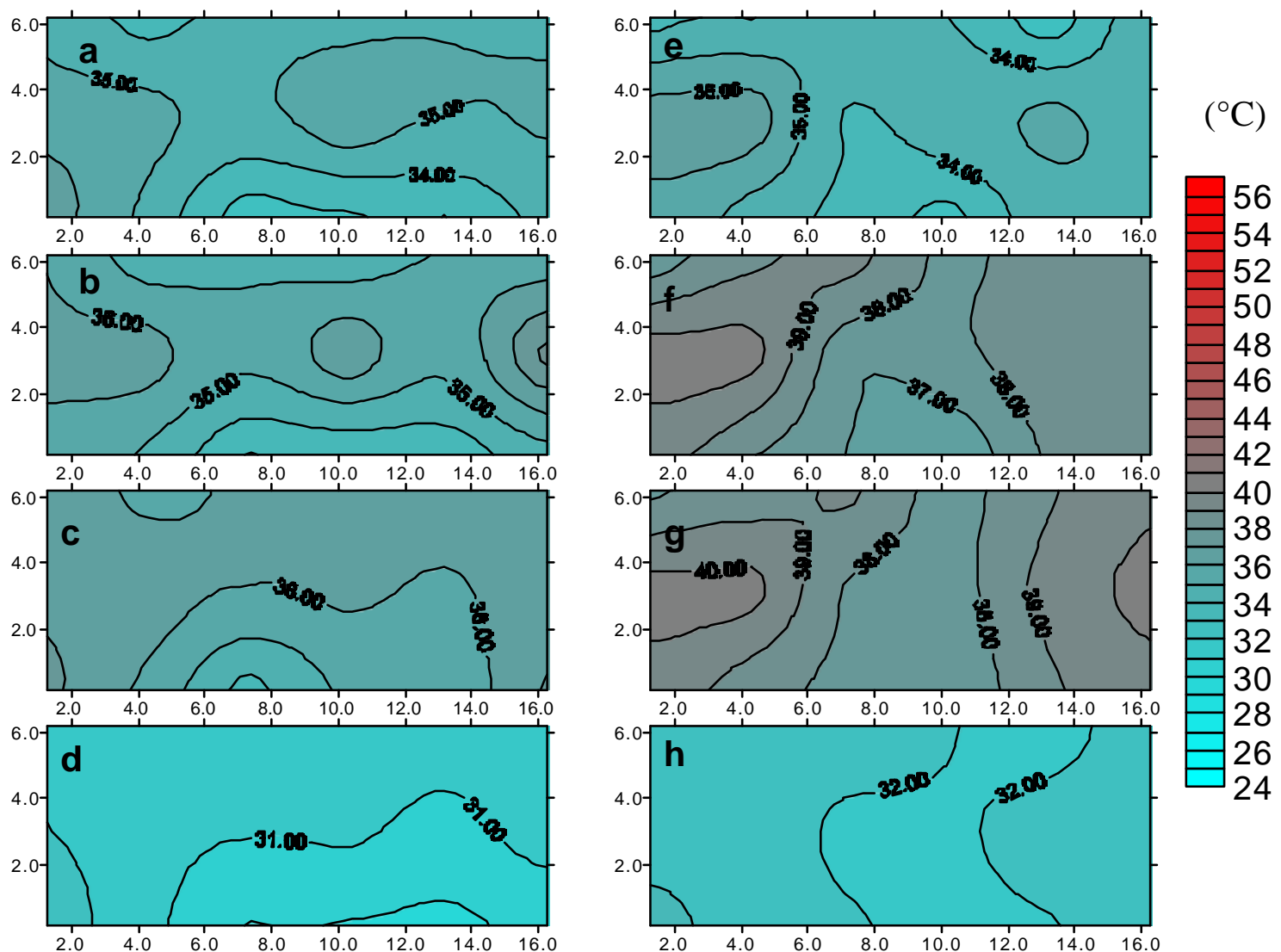

Figura 53. Distribuição de temperatura do ar no ambiente protegido com cortinas laterais abertas a 2,0m de altura e abertura de cortina zenital (53a, 53b e 53c) e no ambiente protegido controle com cortinas laterais abertas a 2,0m de altura (53d, 53e e 53f) para os horários de 11:00h (53a e 53e), 13:00h (53b e 53f), 15:00h (53c e 53g) e 17:00h (53d e 53h) a 2,0m de altura no dia 15/04/00. O eixo x representa a largura (m) e y o comprimento do ambiente protegido (m). 
Às 11:00h (Figuras 53a e 53e) a variação de temperatura do ar nos diferentes pontos de amostragem nos ambientes protegidos, não tiveram grande amplitude, com variação de $3,0^{\circ} \mathrm{C}$. A temperatura média do ar no perfil foi de $34,5^{\circ} \mathrm{C}$ para os ambientes protegidos com cortina zenital aberta e controle. Às 13:00h (Figuras 53b e 53f), a abertura da cortina zenital proporcionou redução de temperatura do ar no ambiente protegido com cortina zenital aberta quando comparado com o ambiente protegido. A temperatura média do ar no perfil no ambiente protegido com abertura da cortina zenital foi de $35,5^{\circ} \mathrm{C}$, enquanto que a temperatura média do ar no perfil no ambiente protegido controle foi de $38,3^{\circ} \mathrm{C}$, ou seja, houve redução de 7,3\%. Ainda com a cortina zenital aberta, o perfil das 15:00h (Figuras 53c e 53f) seguiu a mesma tendência de distribuição que às 13:00h, porém, com maior influência da ação do vento, conforme visto para o perfil de 0,5m de altura (Figura 52c e 52f). Nesse horário, a temperatura média do ar no perfil, com cortina zenital aberta foi de $36,6^{\circ} \mathrm{C}$, enquanto que no ambiente protegido controle foi de $38,6^{\circ} \mathrm{C}$. A redução de temperatura do ar para este perfil foi de 5,2\%. Após o fechamento da cortina zenital (Figuras 53d e 53h), a temperatura do ar no ambiente protegido cortina zenital aberta teve variação de 30,0 a $32,0^{\circ} \mathrm{C}$, com valor médio de temperatura do ar no perfil de $31,2^{\circ} \mathrm{C}$ e no ambiente protegido controle de 32,0 a $33,0^{\circ} \mathrm{C}$, com valor médio de temperatura do ar no perfil de $32,4^{\circ} \mathrm{C}$.

A influência da abertura da cortina zenital foi menor à medida que a abertura das cortinas laterais aumentou, principalmente nos perfis de distribuição mais inferiores $(0,5 \mathrm{~m})$.

4.2.4.4. Cortinas laterais abertas a $3,0 \mathrm{~m}$ de altura.

4.2.4.4.1. Variação da temperatura do ar no ambiente protegido.

Mantendo as cortinas laterais abertas a 3,0m de altura, a cortina zenital foi aberta durante o período das 11 às 15:00h nos dias 18 e 19/04/00. Na Figura 54, observa-se a variação da temperatura média do ar no ambiente protegido testemunha e 
com cortina zenital aberta, durante o decorrer do dia 18/04/00 com abertura da cortina zenital no ambiente E1. A redução da temperatura do ar no ambiente protegido manejado em comparação com o ambiente controle não foi significativa pelo teste $\mathrm{t} e$, portanto, as temperaturas não diferiram entre si. Durante o período em que a cortina zenital permaneceu aberta, a temperatura média do ar foi de $29,5^{\circ} \mathrm{C}$. Nesse mesmo período, a temperatura média do ar no ambiente testemunha foi de $30,4^{\circ} \mathrm{C}$. A diferença de temperatura média do ar entre os ambientes foi de $0,9^{\circ} \mathrm{C}$, representando redução de temperatura do ar de 3,0\%. A média da temperatura do ar externa para esse intervalo foi de $25,2^{\circ} \mathrm{C}$, ficando o ambiente protegido com cortina zenital aberta com temperatura do ar 17,0\% superior à externa e o ambiente protegido com cortina zenital aberta com temperatura do ar $20,6 \%$ acima da externa.

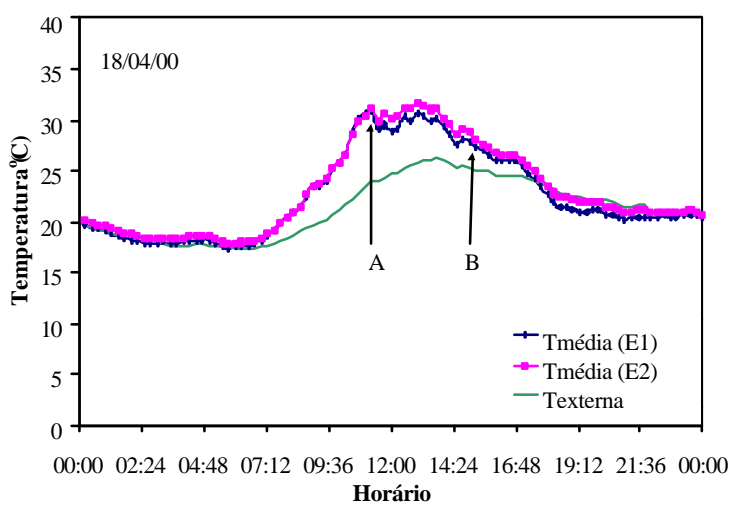

A - abertura da cortina zenital (11:00h).

B - cortina zenital fechada (15:00h).

Figura 54. Variação da temperatura média do ar no ambiente protegido com abertura da cortina zenital e lateral a 3,0m (E1), no ambiente protegido controle com as cortinas laterais abertas a 3,0m (E2) e no ambiente externo, no dia 18/04/00.

Na Figura 55 observa-se a distribuição da temperatura média do ar durante o dia 19/04/00. Também nesse dia, a cortina zenital foi aberta às 11:00h e fechada às 15:00h, enquanto que as laterais estavam abertas a 3,0m de altura. A redução da temperatura do ar no ambiente protegido manejado em comparação com o ambiente controle não foi significativa pelo teste $\mathrm{t} e$, portanto, as temperaturas não diferiram entre si. 
A temperatura média do ar no ambiente protegido com a cortina zenital aberta (E1) foi de $30,8^{\circ} \mathrm{C}$, enquanto que a temperatura média do ar no ambiente controle, no período considerado, foi de $31,4^{\circ} \mathrm{C}$ e a externa $26,5^{\circ} \mathrm{C}$. A temperatura média do ar no ambiente protegido com cortina zenital aberta ficou $0,6^{\circ} \mathrm{C}$ abaixo da temperatura do ar no ambiente protegido controle, ou seja, 1,9\% menor. Isso se deve ao fato de que no dia 19/04/00, a velocidade do vento média nesse intervalo foi de $2,1 \mathrm{~m} / \mathrm{s}$, enquanto que no dia 18/04/00 foi de 1,2m/s. A maior influência do vento na renovação do ar no ambiente protegido, fez com que praticamente não houvesse acúmulo de ar quente nos ambientes protegidos e, conseqüentemente, a abertura da cortina zenital, não surtisse nenhum efeito na média geral da temperatura do ar no ambiente protegido. A umidade relativa média no intervalo considerado foi de 78,1 e 72,9\% para os dias 18 e 19/04/00, respectivamente.

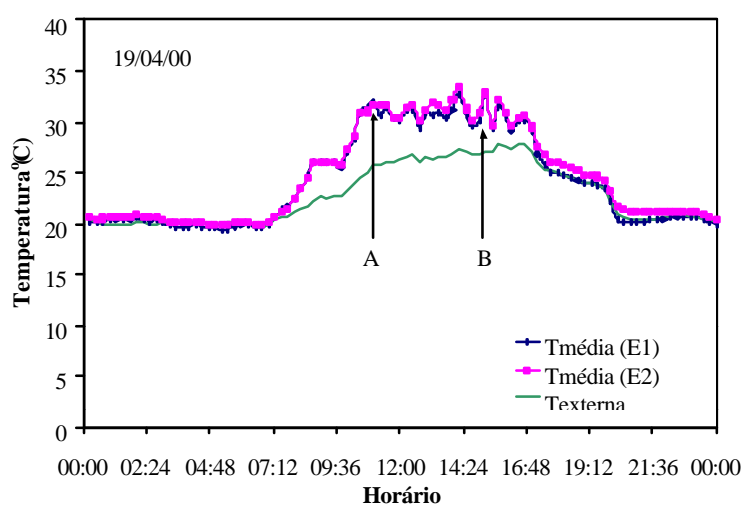

A - abertura da cortina zenital (11:00h).

B - cortina zenital fechada (15:00h).

Figura 55. Variação da temperatura média do ar no ambiente protegido com abertura da cortina zenital e cortina lateral a 3,0m (E1), no ambiente protegido controle com as cortinas laterais abertas a 3,0m (E2) e no ambiente externo, no dia 19/04/00.

A distribuição da temperatura média do ar no ambiente protegido com as cortinas laterais abertas a 3,0m de altura praticamente não foi modificada pela abertura da cortina zenital, principalmente em condições de vento externo maior. $O$ efeito na redução de temperatura média do ar no ambiente protegido causado pela abertura da janela zenital foi maior com a menor abertura (ou altura) das cortinas laterais devido ao 
processo convectivo ou "efeito termo-sifão" descrito por Brun \& Lagier (1985). Concordando com Kai et al. (2000), o efeito da abertura da janela zenital foi mais pronunciado com a abertura das cortinas laterais a $0,5 \mathrm{~m}$ de altura, quando se permitiu menor fluxo de ar pelo manejo de cortinas laterais e maior efeito do processo convectivo.

\subsection{Variação vertical e horizontal de temperatura do ar.}

$\mathrm{Na}$ Figura 56a estão representados os perfis verticais de distribuição de temperatura média do ar no dia 19/04/00 no ambiente protegido onde houve abertura da cortina zenital com as cortinas laterais abertas a 3,0m de altura e na Figura 56b estão representados os perfis verticais de distribuição de temperatura média do ar no ambiente protegido controle com as cortinas laterais abertas a 3,0m de altura.
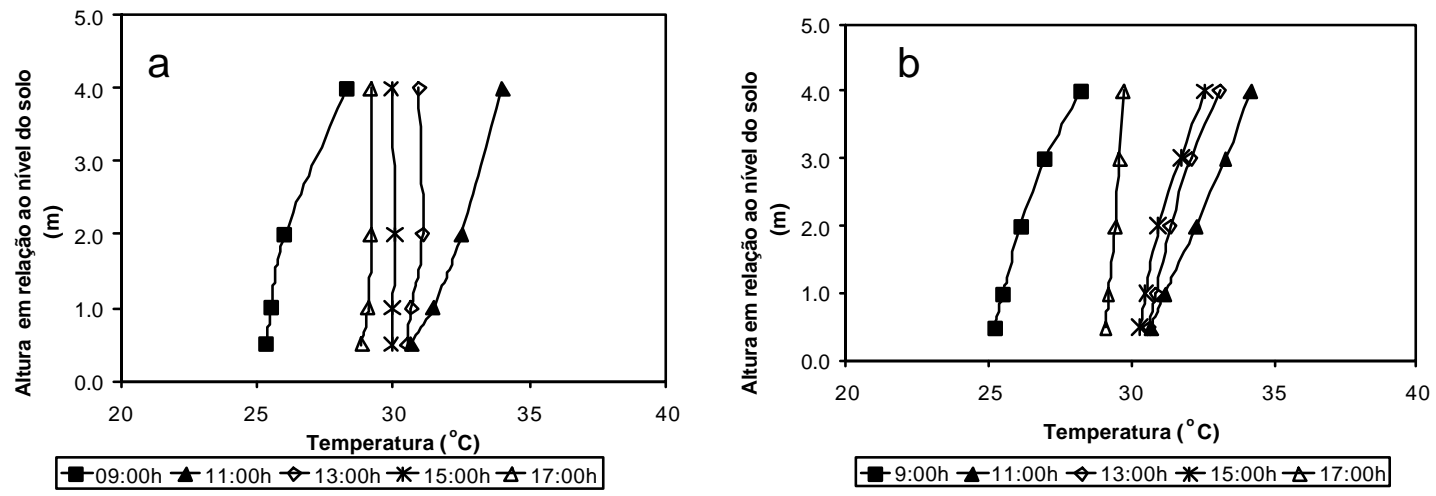

Figura 56. Perfil vertical de temperatura do ar no ambiente protegido com cortinas laterais abertas a 3,0m de altura e abertura da cortina zenital (a) e no ambiente protegido testemunha com cortinas laterais abertas a 3,0m de altura (b), antes da abertura da cortina zenital (9:00h), na abertura (11:00h), durante o período em que a cortina permaneceu aberta (13:00h), no fechamento (15:00h) e após o fechamento da cortina zenital (17:00h), no dia 19/04/00. 
Às 9:00h, representa o horário anterior a abertura da cortina zenital, com as cortinas laterais abertas a 3,0m de altura. Nesse horário, os ambientes protegidos se encontravam praticamente com a mesma distribuição de temperatura do ar, chegando a $25,4^{\circ} \mathrm{C}$ ao nível de $0,5 \mathrm{~m}$ de altura no ambiente protegido com cortina zenital aberta (Figura $56 \mathrm{a}$ ) e de $25,2^{\circ} \mathrm{C}$ no ambiente protegido controle (Figura 56b) e ao nível de $4,0 \mathrm{~m}$ de altura, temperaturas ao redor de $38,3^{\circ} \mathrm{C}$ no ambiente protegido com cortina zenital aberta e de $38,2^{\circ} \mathrm{C}$ no ambiente controle, com temperatura média do ar no perfil de $26,3^{\circ} \mathrm{C}$, nos ambientes. No perfil determinado no momento da abertura da cortina zenital (11:00h) (Figuras 56a e 56b) os ambientes protegidos apresentavam temperaturas semelhantes ao redor de $30,7^{\circ} \mathrm{C}$ a $0,5 \mathrm{~m}$ de altura e $34,1^{\circ} \mathrm{C}$ a $4,0 \mathrm{~m}$ de altura, com média de temperatura do ar no perfil no ambiente protegido com cortina zenital aberta de $32,2^{\circ} \mathrm{C}$ e de $32,3^{\circ} \mathrm{C}$ no ambiente protegido controle. Nos perfis verticais determinados antes da abertura da cortina zenital, observou-se o aumento da temperatura média do ar com o aumento na altura de medida de dados, nos ambientes protegidos, chegando a temperatura do ar máxima a 4,0m, no ponto mais alto do ambiente protegido e próximo da cobertura plástica, conforme visto anteriormente. A abertura de 3,0m de altura das cortinas laterais teve efeito na redução de temperatura do ar em todo o ambiente. Após abertura da cortina zenital às 13:00h, no ambiente protegido com cortina zenital aberta em comparação com o ambiente protegido controle, observou-se a redução de temperatura média do ar pela abertura da cortina zenital e diminuição do gradiente de temperatura do ar a partir de 1,0m de altura, obtendo-se temperatura média do ar homogênea praticamente em todo perfil. As temperaturas médias do ar a $2,0 \mathrm{~m}$ e a $4,0 \mathrm{~m}$ tiveram variação de $0,2^{\circ} \mathrm{C}$, com temperatura do ar média de $31,1^{\circ} \mathrm{C}$ a $2,0 \mathrm{~m}$ e $30,9^{\circ} \mathrm{C}$ a $4,0 \mathrm{~m}$ de altura. Entretanto, no ambiente protegido controle a temperatura do ar se elevou à medida que houve elevação na altura analisada. A temperatura média do ar no perfil vertical no ambiente protegido com cortina zenital aberta foi de $30,8^{\circ} \mathrm{C}$, com temperatura média de $30,5^{\circ} \mathrm{C}$ a $0,5 \mathrm{~m}$ e de $30,9^{\circ} \mathrm{C}$ a $4,0 \mathrm{~m}$ de altura, enquanto que a temperatura média do ar no perfil no ambiente protegido controle foi de $31,5^{\circ} \mathrm{C}$ (com temperatura média de $30,6^{\circ} \mathrm{C}$ a $0,5 \mathrm{~m}$ e de $33,1^{\circ} \mathrm{C}$ a $4,0 \mathrm{~m}$ de altura). A abertura da cortina zenital nesse horário reduziu a temperatura média do ar no perfil de 2,2\%. Observou-se que a temperatura média do ar nos ambientes protegidos foi semelhante nos níveis de $0,5 \mathrm{~m}$ de 
altura, com temperatura média do ar de $30,5^{\circ} \mathrm{C}$ no ambiente protegido com cortina zenital aberta e $30,6^{\circ} \mathrm{C}$ no ambiente protegido controle. Entretanto, com a cortina zenital aberta, a temperatura do ar no ambiente não se elevou como ocorreu no ambiente protegido controle. No perfil correspondente às 15:00h, obteve-se a mesma distribuição vertical de temperatura do ar observada no perfil das 13:00h. A temperatura média do ar do perfil vertical no ambiente protegido com cortina zenital aberta foi de $30,0^{\circ} \mathrm{C}$, com temperatura média de $29,9^{\circ} \mathrm{C}$ a $0,5 \mathrm{~m}$ e de $30,0^{\circ} \mathrm{C}$ a $4,0 \mathrm{~m}$ de altura e a temperatura média do ar do perfil vertical no ambiente protegido controle foi de $31,2^{\circ} \mathrm{C}$, com temperatura média de $30,3^{\circ} \mathrm{C}$ a $0,5 \mathrm{~m}$ e $32,6^{\circ} \mathrm{C}$ a 4,0m. Houve uma redução média de temperatura do ar de 3,8\%. Nesse horário houve maior diferença de temperatura do ar entre os ambientes protegidos. No ambiente protegido com cortina zenital aberta, a variação de temperatura entre a temperatura média do ar obtida a $2,0 \mathrm{~m}$ e a obtida a $4,0 \mathrm{~m}$ foi e $0,2^{\circ} \mathrm{C}$. Nos ambientes protegidos, os perfis correspondentes às 17:00h, a distribuição de temperatura do ar foram semelhantes nos ambientes protegidos, ficando o ambiente protegido controle com temperatura do ar de $0,1^{\circ} \mathrm{C}$ superior. A temperatura média do ar do perfil vertical no ambiente protegido com cortina zenital aberta foi de $29,3^{\circ} \mathrm{C}$, com temperatura média de $28,6^{\circ} \mathrm{C}$ a $0,5 \mathrm{~m}$ e de $29,2^{\circ} \mathrm{C}$ a 4,0m de altura e a temperatura média do ar do perfil vertical no ambiente protegido controle foi de $29,4^{\circ} \mathrm{C}$, com temperatura média de $29,1^{\circ} \mathrm{C}$ a $0,5 \mathrm{~m}$ e $29,5^{\circ} \mathrm{C}$ a $4,0 \mathrm{~m}$. Houve redução média da temperatura do ar de $0,3 \%$.

Na Figura 57 estão representadas as isotermas a 0,5m de altura no dia 19/04/00 para o ambiente protegido com cortinas laterais abertas a 3,0m e abertura de cortina zenital (57a, 57b e 57c) e o ambiente protegido controle com cortinas laterais abertas a 3,0m de altura (57d, 57e e 57f) para os horários de 11:00h (57a e 57e), 13:00h (57b e 57f), 15:00h (57c e 57g) e 17:00h (57d e 57h).

Às 11:00h (Figuras 57a e 57e) a variação de temperatura do ar nos ambientes protegidos foi de $1,0^{\circ} \mathrm{C}$, com distribuição de temperaturas bastantes homogênea. Nesse horário a velocidade do vento foi de $1,5 \mathrm{~m} / \mathrm{s}$ na direção sudoeste. A temperatura média do ar do perfil horizontal foi de 30,5 e $30,3^{\circ} \mathrm{C}$ para o ambiente protegido com cortina zenital aberta e testemunha, respectivamente. 

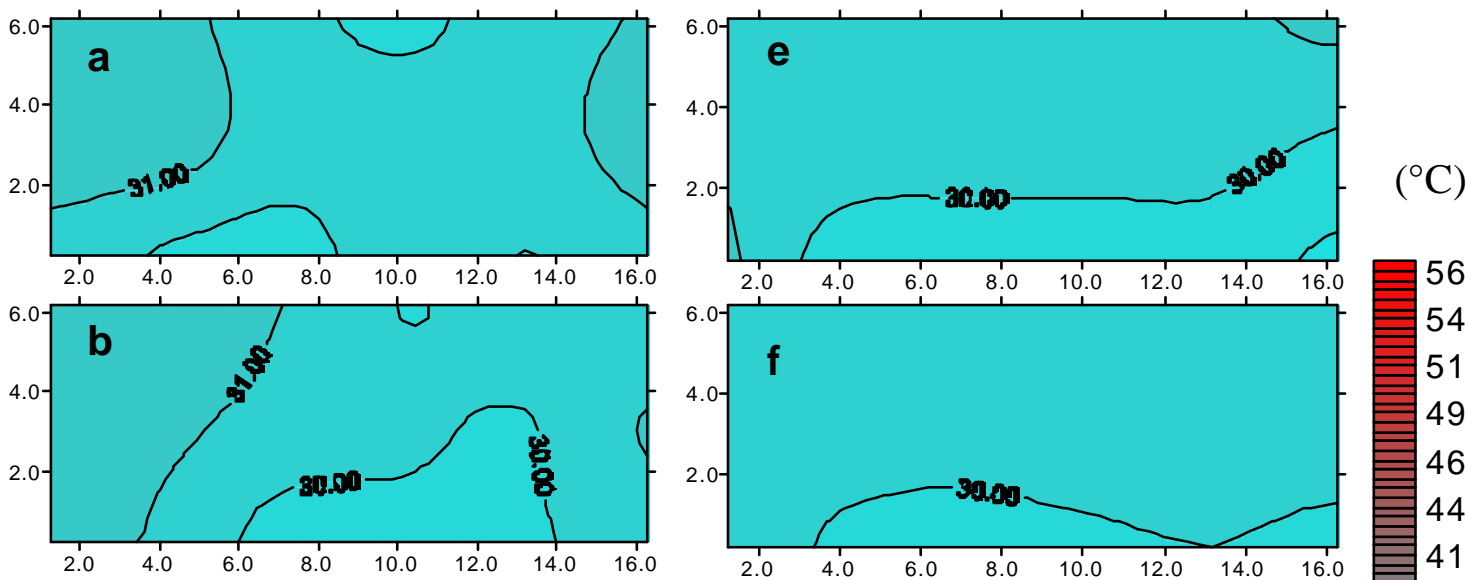

54

51

49

46

44

41
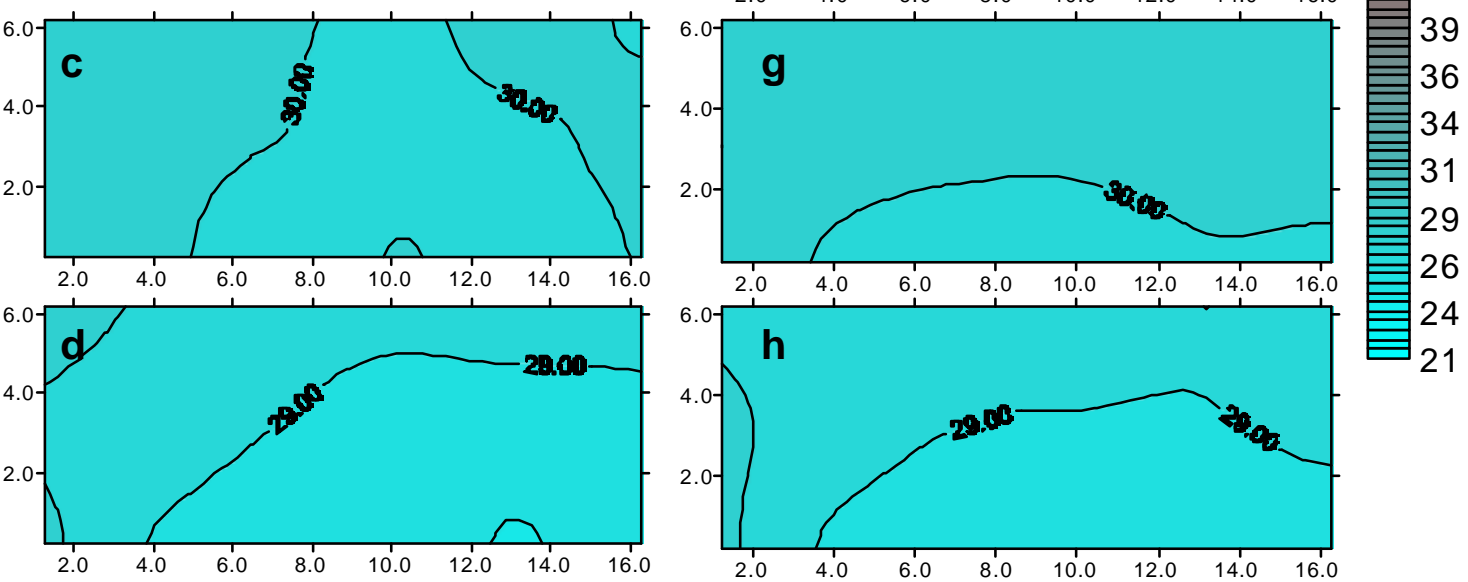

Figura 57. Distribuição de temperatura do ar no ambiente protegido com cortinas laterais abertas a 3,0m e abertura de cortina zenital (57a, 57b e 57c) e no ambiente protegido controle com cortinas laterais abertas a 3,0m de altura (57d, 57e e 57f) para os horários de 11:00h (57a e 57e), 13:00h (57b e 57f), 15:00h (57c e 57g) e 17:00h (57d e 57h) a 0,5m de altura no dia 19/04/00. O eixo x representa a largura $(\mathrm{m})$ e y o comprimento do ambiente protegido (m).

Às 13:00h, as temperaturas médias do ar no ambiente protegido com a cortina zenital aberta (Figura 57b) e controle (Figura 57f) tiveram distribuição regular, com área de menor temperatura do ar no lado sul do ambiente protegido evidenciando a entrada de ar lateral. A temperatura média do ar no perfil no ambiente protegido com cortina zenital aberta foi de $30,6^{\circ} \mathrm{C}$, enquanto que a temperatura média do ar no perfil no ambiente protegido controle foi de $30,5^{\circ} \mathrm{C}$. Nesta situação, a abertura da janela zenital não reduziu a temperatura média do ar no perfil a $0,5 \mathrm{~m}$ de altura. A velocidade do vento média às 
13:00h foi de 2,4m/s na direção sudoeste. Às 15:00h, a distribuição de temperatura do ar nos ambientes protegidos permaneceu a mesma, porém com temperaturas médias do ar de 30,1 e $30,3^{\circ} \mathrm{C}$, para o ambiente com cortina zenital aberta (Figura 57c) e testemunha (Figura $57 \mathrm{~g}$ ), respectivamente, proporcionando redução de $0,7 \%$. A velocidade do vento nesse período foi de $1,7 \mathrm{~m} / \mathrm{s}$ na direção noroeste. Nas Figuras $57 \mathrm{~d}$ e $57 \mathrm{~h}$ estão representadas as distribuições horizontais de temperatura do ar no ambiente protegido após o fechamento da cortina zenital. A distribuição de temperatura do ar no ambiente protegido com abertura de cortina zenital (Figura 57d) foi semelhantes as temperaturas do ar do ambiente protegido controle (Figura 57h) com temperatura média do ar no perfil de $29,1^{\circ} \mathrm{C}$. A temperatura média do ar no ambiente protegido não variou no decorrer do dia entre os ambientes comparados. A abertura da janela zenital não influenciou na redução ou modificação das condições de distribuição de temperatura do ar no ambiente protegido.

Na Figura 58 estão representadas as isotermas a 2,0m de altura no dia 19/04/00 para o ambiente protegido com cortinas laterais abertas a 3,0m de altura e abertura de cortina zenital (58a, 58b e 58c) e o ambiente protegido controle com cortinas laterais abertas a 3,0m de altura (58d, 58e e 58f) para os horários de 11:00h (58a e 58e), 13:00h (58b e 58f), 15:00h (58c e 58g) e 17:00h (58d e 58h).

A distribuição de temperatura do ar no ambiente protegido a 2,0m de altura, não foi diferente da distribuição ocorrida a $0,5 \mathrm{~m}$ de altura.

Às 11:00h (Figuras 58a e 58e) a variação de temperatura do ar nos diferentes pontos de amostragem nos ambientes protegidos, não tiveram grande amplitude, com variação de $1,0^{\circ} \mathrm{C}$. A temperatura média do ar no perfil foi de $31,1^{\circ} \mathrm{C}$ para os ambientes protegidos com cortina zenital aberta e controle. Às 13:00h (Figuras 58b e 58f), a temperatura média do ar do perfil no ambiente protegido com abertura da cortina enital foi de $30,8^{\circ} \mathrm{C}$, enquanto que a temperatura média do ar do perfil no ambiente protegido controle foi de $31,0^{\circ} \mathrm{C}$, ou seja, houve redução de $0,6 \%$. Ainda com a cortina zenital aberta, às $15: 00 \mathrm{~h}$ (Figuras $58 \mathrm{c}$ e 58f), a temperatura média do ar do perfil com cortina zenital aberta foi de $29,9^{\circ} \mathrm{C}$, enquanto que no ambiente protegido controle foi de $30,7^{\circ} \mathrm{C}$. A redução de temperatura do ar para este perfil foi de $2,6 \%$. 

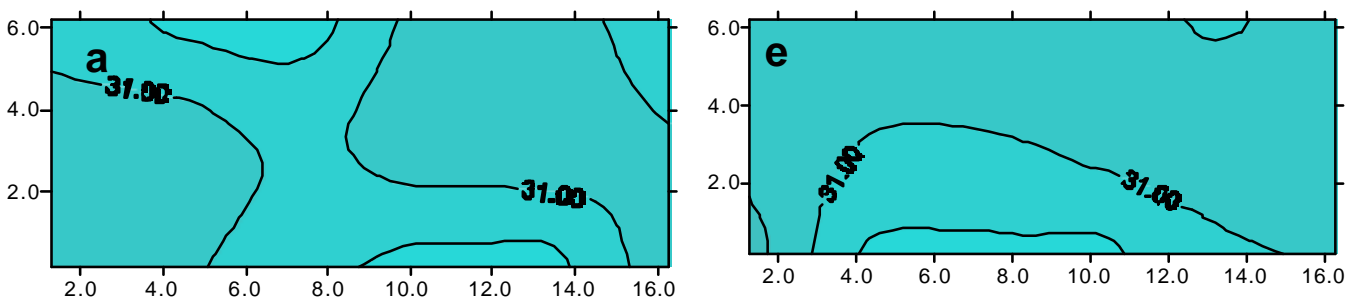

$\left({ }^{\circ} \mathrm{C}\right)$
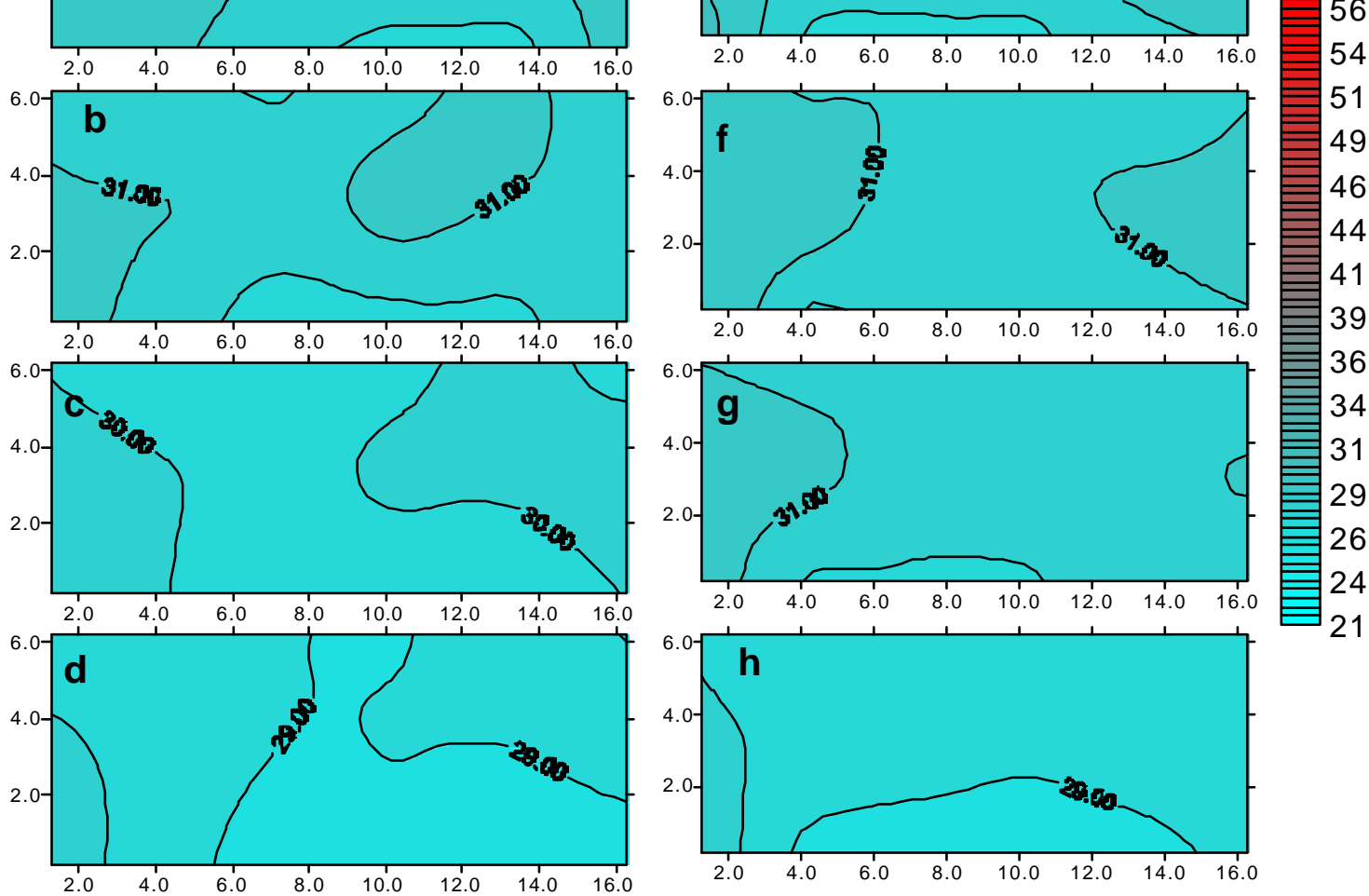

Figura 58. Distribuição de temperatura do ar no ambiente protegido com cortinas laterais abertas a 3,0m de altura e abertura de cortina zenital (58a, 58b e 58c) e no ambiente protegido controle com cortinas laterais abertas a 3,0m de altura (58d, 58e e 58f) para os horários de 11:00h (58a e 58e), 13:00h (58b e 58f), 15:00h (58c e 58g) e 17:00h (58d e 58h) a 2,0m de altura no dia 19/04/00. O eixo x representa a largura (m) e y o comprimento do ambiente protegido (m).

Após o fechamento da cortina zenital (17:00h, Figuras 58d e 58h), a temperatura média do ar no perfil no ambiente protegido com cortina zenital aberta foi de $29,2^{\circ} \mathrm{C}$ e no ambiente protegido controle de $29,4^{\circ} \mathrm{C}$.

A influência da abertura da cortina zenital foi menor à medida que se incrementou a altura das cortinas laterais, principalmente nos perfis de distribuição mais inferiores $(0,5 \mathrm{~m})$. Com cortinas abertas a 3,0m de altura a abertura da cortina zenital 
teve pouca ou nenhuma influência na redução da temperatura do ar no ambiente protegido.

4.2.5. Abertura de cortinas laterais a diferentes alturas.

4.2.5.1. Abertura da cortina lateral a 2,5m comparada com abertura a 1,0m de altura em relação ao nível do solo.

\subsection{Variação da temperatura do ar.}

Mantendo-se um dos ambientes protegidos com as cortinas laterais abertas a $2,5 \mathrm{~m}$ de altura (E1) e o outro com as cortinas laterais a 1,0m de altura (E2), comparou-se a temperatura média do ar nos ambientes.

Na Figura 59 observa-se a diferença de temperatura média do ar nos ambientes protegidos decorrentes dos diferentes manejos e no ambiente externo para o dia 24/02/00. A redução da temperatura do ar no ambiente protegido com cortinas laterais abertas a 2,5m de altura em comparação com o ambiente protegido com cortinas abertas a 1,0m de altura foi significativa a $1,0 \%$ de probabilidade pelo teste $\mathrm{t}$.

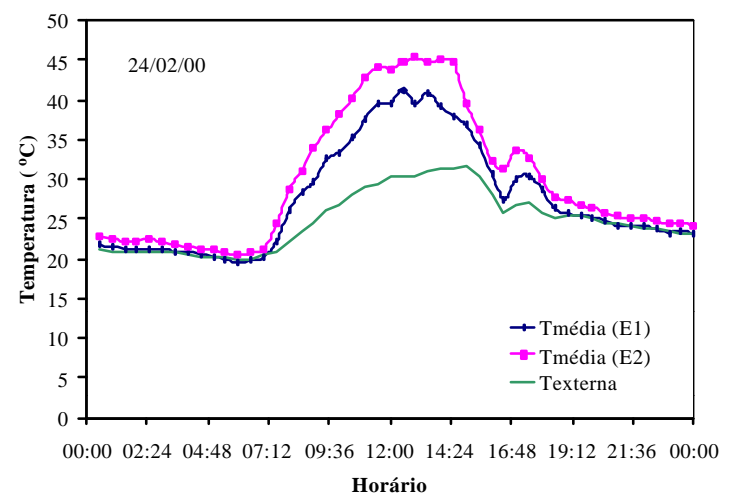

Figura 59. Variação da temperatura média do ar no ambiente protegido com as cortinas laterais abertas a 2,5m (E1), no ambiente protegido com as cortinas laterais abertas a 1,0m (E2) e no ambiente externo, no dia 24/02/00. 
A temperatura média do ar durante todo o dia no ambiente protegido com as cortinas laterais abertas a $2,5 \mathrm{~m}$ (E1) foi de $27,6^{\circ} \mathrm{C}$ e a no ambiente protegido com cortinas a $1,0 \mathrm{~m}(\mathrm{E} 2)$ foi de $29,9^{\circ} \mathrm{C}$. A diferença de temperatura do ar foi de $2,3^{\circ} \mathrm{C}$, o que correspondeu a uma redução de temperatura do ar de 7,7\% da maior temperatura em relação a menor. A temperatura média do ar externa durante o dia foi de $24,8^{\circ} \mathrm{C}$. Assim, o ambiente E1 que ficou com as cortinas abertas a 2,5m de altura em relação ao nível do solo teve temperatura média diária $11,25 \%$ superior ao ambiente externo, enquanto que o ambiente (E2), teve temperaturas médias diárias de 20,5\% superior. A umidade relativa média do dia foi de $84,5 \%$ e a velocidade do vento de $0,65 \mathrm{~m} / \mathrm{s}$. Considerando-se somente o período do dia com luz, a temperatura média do ar no ambiente E1 foi de $31,4^{\circ} \mathrm{C}$ enquanto que o ambiente $\mathrm{E} 2$ foi de $34,6^{\circ} \mathrm{C}$, ou seja, $3,2^{\circ} \mathrm{C}$ superior, ou $9,4 \%$. Da mesma forma, a temperatura média do ar externa foi de $26,7^{\circ} \mathrm{C}$, ficando o E1 com temperaturas $17,4 \%$ superior e o E2, 29,6\%. A umidade relativa média nesse período foi de $76,8 \%$ e a velocidade do vento média foi $0,87 \mathrm{~m} / \mathrm{s}$.

Na Figura 60 observa-se a diferença de temperatura média do ar nos ambientes protegidos decorrentes dos diferentes manejos e no ambiente externo para o dia 29/02/00.

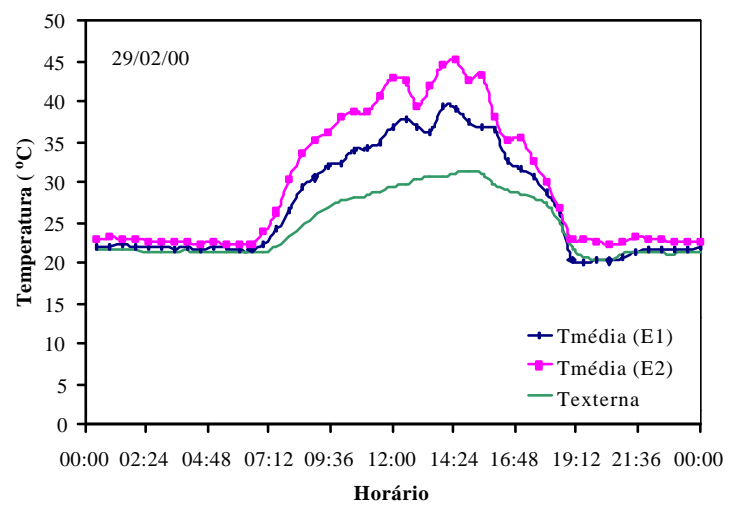

Figura 60. Variação da temperatura média do ar no ambiente protegido com as cortinas laterais abertas a 2,5m (E1), no ambiente protegido com as cortinas laterais abertas a 1,0m (E2) e no ambiente externo, no dia 29/02/00. 
A redução da temperatura do ar no ambiente protegido com cortinas laterais abertas a 2,5m de altura em comparação com o ambiente protegido com cortinas abertas a 1,0m de altura foi significativa a 1,0\% de probabilidade pelo teste $t$.

A temperatura média do ar diária no ambiente protegido com as cortinas laterais abertas a $2,5 \mathrm{~m}$ de altura (E1) foi de $27,2^{\circ} \mathrm{C}$ e a temperatura média do ar diária para o ambiente protegido com as cortinas abertas a $1,0 \mathrm{~m}$ de altura (E2) foi de $29,8^{\circ} \mathrm{C}$. A diferença de temperatura do ar entre os ambientes protegidos foi de $2,6^{\circ} \mathrm{C}$, ou seja, a temperatura média do ar no ambiente protegido E1 ficou 8,9\% abaixo da temperatura média do ar no ambiente protegido E2. A temperatura média diária do ar externo foi de $24,6^{\circ} \mathrm{C}$. Comparando-se com a temperatura média diária do ar no ambiente protegido E1, temos que esta ficou 10,4\% acima da externa e a temperatura média do ar no ambiente protegido E2 ficou 21,1\% acima da mesma. A umidade relativa média diária no ambiente externo foi de $89,1 \%$ e a velocidade do vento foi de $1,25 \mathrm{~m} / \mathrm{s}$.

Entretanto, a temperatura média do ar, considerando-se somente o período com luz para o ambiente protegido $\mathrm{E} 1$, foi de $31,3^{\circ} \mathrm{C}$, enquanto que para o ambiente protegido $\mathrm{E} 2$ foi de $34,8^{\circ} \mathrm{C}$. A diferença de temperatura do ar entre $\mathrm{E} 1$ e $\mathrm{E} 2$ foi de $3,5^{\circ} \mathrm{C}$, ou seja, E1 teve temperatura média do ar 10,1\% abaixo da temperatura média do ar de E2. A temperatura média do ar externa foi de $27,0^{\circ} \mathrm{C}$. Assim, a temperatura média do ar no ambiente protegido E1 ficou 11,8\% acima da temperatura média do ar externo e o ambiente E2 ficou $29,0 \%$ maior.

4.2.5.1.2. Variação vertical e horizontal de temperatura do ar.

Na Figura 61a estão representados os perfis verticais de distribuição de temperatura média do ar no dia 29/02/00 no ambiente protegido onde houve abertura da cortina lateral a 2,5m de altura (E1) e na Figura 61b estão representados os perfis verticais de distribuição de temperatura média do ar no ambiente protegido com as cortinas laterais abertas a 1,0m de altura (E2). 

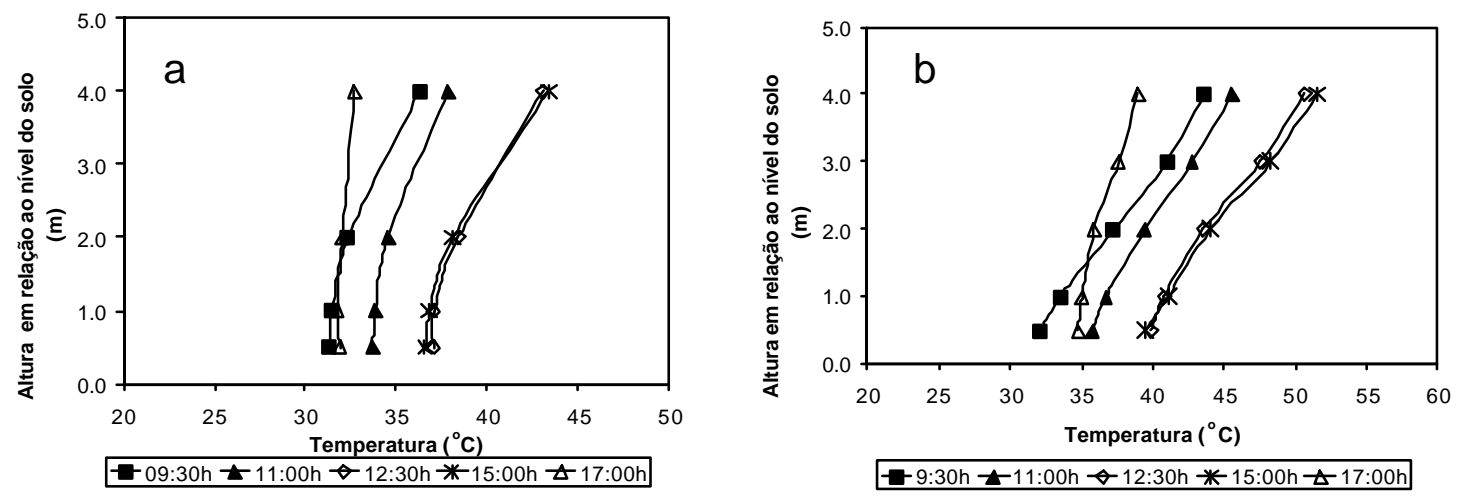

Figura 61. Perfil vertical de temperatura do ar no ambiente protegido com cortinas laterais abertas a $2,5 \mathrm{~m}$ de altura (a) e no ambiente protegido com cortinas laterais abertas a 1,0m de altura (b), às 9:30h, 11:00h, 12:30h, 15:00h e 17:00h, no dia 29/02/00.

Durante todo o decorrer do dia, a temperatura média do ar no ambiente protegido com as cortinas laterais abertas a 1,0m de altura (E2), teve maior temperatura média do ar que o ambiente protegido com as cortinas laterais abertas a 2,5m (E1).

Às 9:30h, a temperatura média do ar no ambiente protegido (E1) no perfil vertical ao nível de $0,5 \mathrm{~m}$ foi de a $31,3^{\circ} \mathrm{C}$ (Figura 61a), enquanto que no ambiente protegido com as cortinas abertas a $1,0 \mathrm{~m}$ (Figura $61 \mathrm{~b}$ ) foi de $32,2^{\circ} \mathrm{C}$. A $4,0 \mathrm{~m}$ de altura, a temperatura média do ar no perfil no ambiente protegido com cortinas a $2,5 \mathrm{~m}$ foi de $36,3^{\circ} \mathrm{C}$ e no ambiente protegido com cortinas abertas a $1,0 \mathrm{~m}$ foi de $43,6^{\circ} \mathrm{C}$. A temperatura média do ar no perfil no ambiente com cortinas a $2,5 \mathrm{~m}$ foi de $32,9^{\circ} \mathrm{C}$ e no ambiente com cortinas a $1,0 \mathrm{~m}$ foi de $37,5^{\circ} \mathrm{C}$. O ambiente protegido com cortinas abertas a 2,5m ficou com temperatura do ar $12,3 \%$ inferior à temperatura do ar no ambiente protegido com cortinas a 1,0m. No perfil determinado às 11:00h, o ambiente protegido com cortinas abertas a 2,5m de altura apresentava temperatura média do ar a $0,5 \mathrm{~m}$ de altura de $33,7^{\circ} \mathrm{C}$ e a $4,0 \mathrm{~m}$ de altura de $37,8^{\circ} \mathrm{C}$, com temperatura média do ar no perfil de $35,0^{\circ} \mathrm{C}$. No ambiente protegido com cortinas abertas a $1,0 \mathrm{~m}$ de altura, para o nível de $0,5 \mathrm{~m}$, a temperatura do ar foi de $35,7^{\circ} \mathrm{C}$ e para o nível de $4,0 \mathrm{~m}$ foi de $45,6^{\circ} \mathrm{C}$, com temperatura média do ar de $40,0^{\circ} \mathrm{C}$. A redução de temperatura foi de $12,5 \%$. Em todos os perfis verticais determinados, observou-se o aumento da temperatura média do ar com o aumento na altura de coleta de dados, nos 
ambientes protegidos, chegando a temperatura máxima a $4,0 \mathrm{~m}$, no ponto mais alto no ambiente protegido e próximo da cobertura plástica, conforme visto anteriormente de acordo com a teoria do "efeito termo-sifão" descrito por Brun \& Lagier (1985). A abertura de $2,5 \mathrm{~m}$ de altura das cortinas laterais teve efeito na redução da temperatura do ar principalmente até a $2,0 \mathrm{~m}$ de altura, enquanto que no ambiente protegido com cortinas abertas a 1,0m, esse efeito não pode ser visualizado. Às 12:30h, no ambiente protegido com cortinas abertas a $2,5 \mathrm{~m}$, a temperatura média do ar a $0,5 \mathrm{~m}$ foi de $37,5^{\circ} \mathrm{C}$ e a $4,0 \mathrm{~m}$ de $43,0^{\circ} \mathrm{C}$, com temperatura média do ar no perfil de $38,9^{\circ} \mathrm{C}$. No ambiente protegido com cortinas abertas a $1,0 \mathrm{~m}$, a temperatura média do ar $0,5 \mathrm{~m}$ foi de $39,9^{\circ} \mathrm{C}$ e a $4,0 \mathrm{~m}$ foi de 50,6 ${ }^{\circ} \mathrm{C}$, com temperatura média do ar no perfil de $44,4^{\circ} \mathrm{C}$. A temperatura média do ar no perfil no ambiente protegido com cortinas abertas a $2,5 \mathrm{~m}$ ficou $12,4 \%$ abaixo da temperatura do ambiente com abertura da cortina lateral a 1,0m de altura. Às 15:00h, a temperatura média do ar no perfil vertical no ambiente protegido com cortinas abertas a $2,5 \mathrm{~m}$ foi de $38,7^{\circ} \mathrm{C}$, com temperatura média de $36,6^{\circ} \mathrm{C}$ a $0,5 \mathrm{~m}$ e de $43,3^{\circ} \mathrm{C}$ a $4,0 \mathrm{~m}$ de altura, enquanto que a temperatura média do ar no perfil no ambiente protegido com cortinas abertas a 1,0m foi de $44,8^{\circ} \mathrm{C}$, com temperatura média de $39,5^{\circ} \mathrm{C}$ a $0,5 \mathrm{~m}$ e de $51,5^{\circ} \mathrm{C}$ a $4,0 \mathrm{~m}$ de altura. A redução de temperatura média do ar no perfil foi de 13,6\% devido ao aumento da abertura da cortina lateral. Às 17:00h a temperatura média do ar no perfil vertical no ambiente protegido com cortinas abertas a $2,5 \mathrm{~m}$ foi de $32,1^{\circ} \mathrm{C}$, com temperatura média de $31,9^{\circ} \mathrm{C}$ a $0,5 \mathrm{~m}$ e de $32,7^{\circ} \mathrm{C}$ a $4,0 \mathrm{~m}$ de altura e a temperatura média do ar no perfil vertical no ambiente protegido com cortinas a $1,0 \mathrm{~m}$ foi de $36,5^{\circ} \mathrm{C}$, com temperatura média de $34,8^{\circ} \mathrm{C}$ a $0,5 \mathrm{~m}$ e $39,0^{\circ} \mathrm{C}$ a $4,0 \mathrm{~m}$, representando uma redução média de temperatura de $12,1 \%$.

A Figura 62 apresenta as isotermas a $0,5 \mathrm{~m}$ de altura em relação ao nível do solo no dia 29/02/00 para o ambiente protegido com cortinas laterais abertas a 2,5m (62a, 62b e 62c) e o ambiente protegido com cortinas laterais abertas a 1,0m de altura $(62 \mathrm{~d}, 62 \mathrm{e}$ e 62f) para os horários de 9:30h (62a e 62e), 12:30h (62b e 62f), 15:00h (62c e 62g) e 17:00h (62d e 62h). 

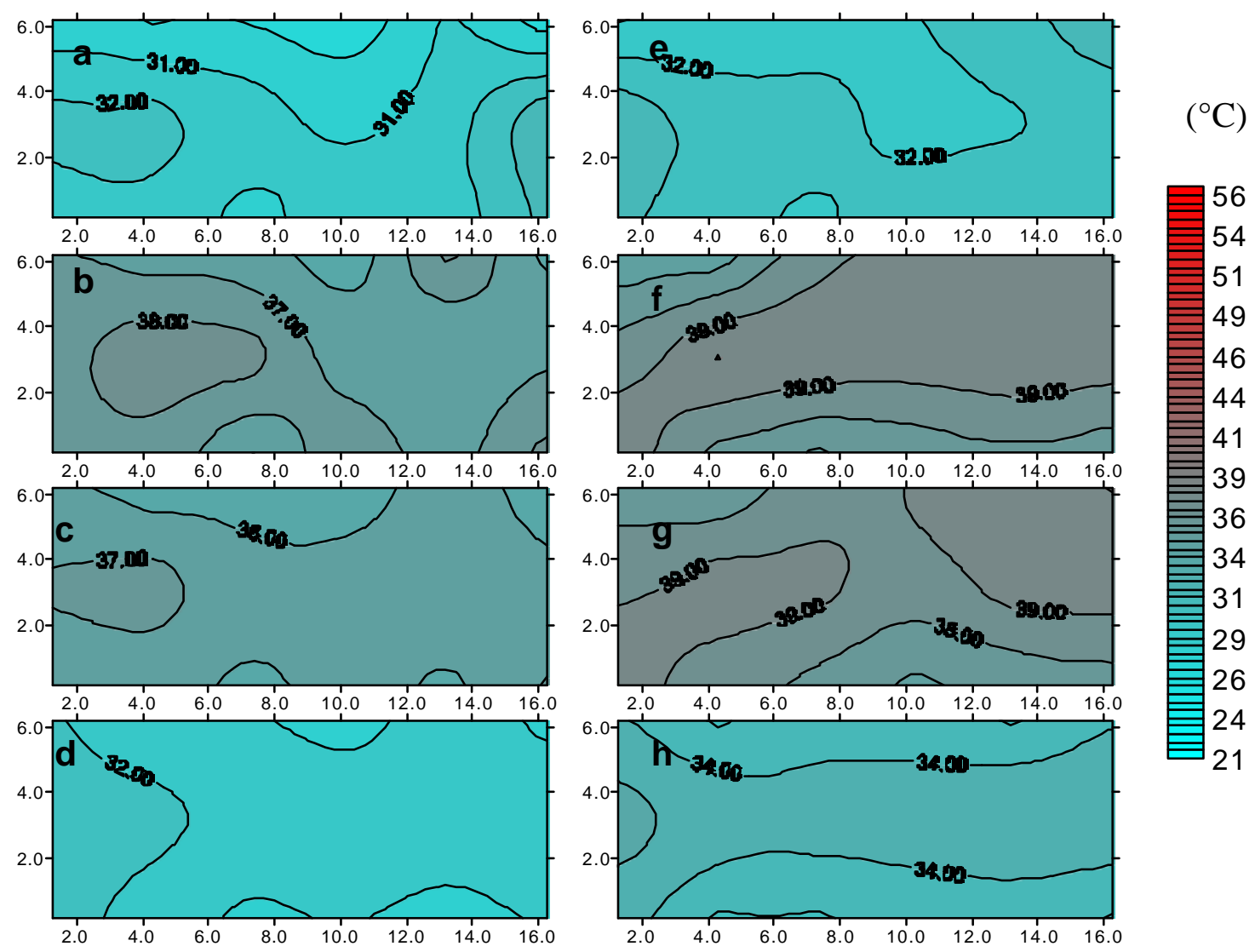

Figura 62. Distribuição de temperatura do ar no ambiente protegido com cortinas laterais abertas a 2,5m de altura (62a, 62b e 62c) e no ambiente protegido com cortinas laterais abertas a 1,0m de altura (62d, 62e e 62f) para os horários de 9:30h (62a e 62e), 12:30h (62b e 62f), 15:00h (62c e 62g) e 17:00h (62d e $62 \mathrm{~h}$ ) a $0,5 \mathrm{~m}$ de altura no dia 29/02/00. O eixo x representa a largura (m) e y o comprimento do ambiente protegido (m).

Às 9:30h (Figuras 62a e 62e) a variação de temperatura do ar nos ambientes protegidos foi de $1,0^{\circ} \mathrm{C}$ a $2,0^{\circ} \mathrm{C}$, com distribuição de temperaturas homogênea. Nesse horário a velocidade do vento foi de $1,75 \mathrm{~m} / \mathrm{s}$, na direção nordeste, reduzindo a temperatura do ar no perfil de distribuição horizontal de temperatura do ar. A temperatura média do ar no perfil horizontal foi de 31,2 e $32,2^{\circ} \mathrm{C}$ para o ambiente protegido com cortinas laterais abertas a 2,5m e com cortinas laterais abertas a $1,0 \mathrm{~m}$, respectivamente, ou seja, a temperatura do ar no ambiente protegido com cortinas abertas a 2,5m ficou 3,1\% inferior a no ambiente protegido com cortinas a 1,0m. 
Às 12:30h, as temperaturas médias do ar no ambiente protegido com as cortinas laterais abertas a 2,5m de altura (Figura 62b) e ambiente protegido com cortinas laterais abertas a 1,0m de altura (Figura 62f) tiveram distribuição de temperatura do ar com menor temperatura do ar do lado sul no ambiente protegido evidenciando a direção predominante do vento $(1,7 \mathrm{~m} / \mathrm{s}$, direção sudeste). A temperatura média do ar no perfil no ambiente protegido com cortinas laterais abertas a $2,5 \mathrm{~m}$ foi de $37,3^{\circ} \mathrm{C}$, enquanto que a temperatura média do ar no perfil no ambiente protegido com cortinas abertas a 1,0m foi de $38,2^{\circ} \mathrm{C}$. A temperatura média do ar no perfil com cortinas laterais abertas a $2,5 \mathrm{~m}$ ficou 2,4\% abaixo da temperatura média do ar no perfil com cortinas abertas a 1,0m. Às 15:00h, as temperaturas médias do ar foram de 36,5 e $38,3^{\circ} \mathrm{C}$, para o ambiente protegido com cortinas laterais abertas a 2,5m de altura (Figura 62c) e ambiente com cortinas laterais abertas a 1,0m (Figura 62g), respectivamente, proporcionando redução de 4,7\%. A velocidade do vento nesse período foi de 2,0m/s na direção sudoeste. Nas Figuras 62d e 62h (às 17:00h) estão representadas as distribuições horizontais de temperatura do ar no ambiente protegido com cortinas laterais abertas a 2,5m e ambiente protegido com cortinas laterais abertas a 1,0m respectivamente. A distribuição de temperatura do ar nos ambientes protegidos foram semelhantes, porém com temperatura média do ar no perfil de 31,5 e $33,9^{\circ} \mathrm{C}$, respectivamente. A redução de temperatura do ar 6 i de $7,1 \%$. A velocidade do vento foi de $2,2 \mathrm{~m} / \mathrm{s}$, na direção sudoeste.

Na Figura 63 estão representadas as isotermas a 2,0m de altura em relação ao nível do solo no dia 29/02/00 para o ambiente protegido com cortinas laterais abertas a $2,5 \mathrm{~m}$ de altura $(63 \mathrm{a}, 63 \mathrm{~b}$ e 63c) e o ambiente protegido com cortinas laterais abertas a 1,0m de altura (63d, 63e e 63f) para os horários de 9:30h (63a e 63e), 12:30h (63b e 63f), 15:00h (63c e 63g) e 17:00h (63d e 63h).

Às 9:30h (Figuras 63a e 63e) a variação de temperatura do ar nos diferentes pontos de amostragem nos ambientes protegidos foi de $2,0^{\circ} \mathrm{C}$. A temperatura média do ar no perfil do ambiente protegido com cortinas laterais abertas a $2,5 \mathrm{~m}$ foi de $31,9^{\circ} \mathrm{C}$ e para o ambiente protegido com cortinas laterais abertas a $1,0 \mathrm{~m}$ foi de $36,5^{\circ} \mathrm{C}$. A temperatura do ar no ambiente protegido com cortinas abertas a 2,5m foi $12,6 \%$ inferior a temperatura do ar no ambiente protegido com cortinas abertas a 1,0m. 

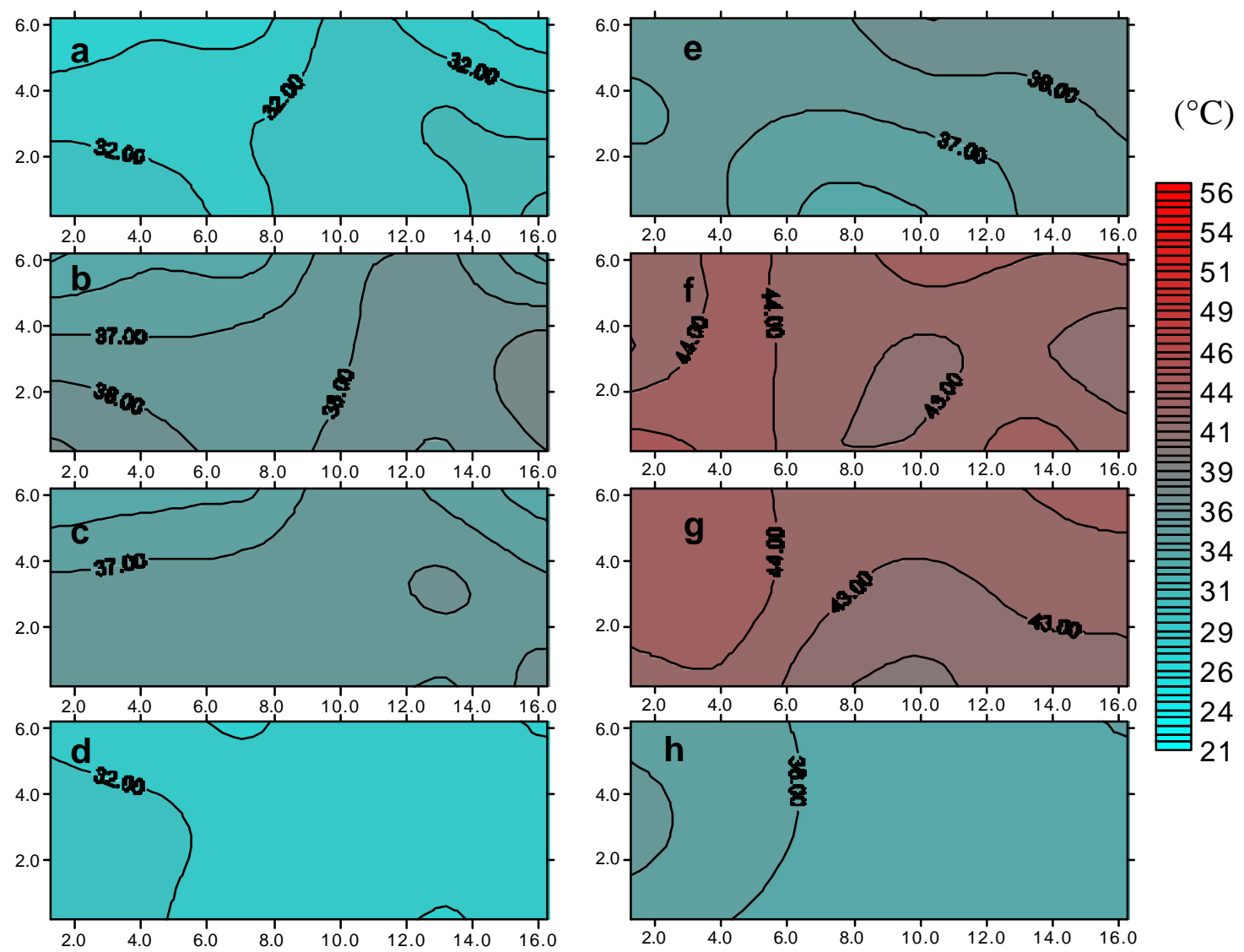

Figura 63. Distribuição de temperatura do ar no ambiente protegido com cortinas laterais abertas a $2,5 \mathrm{~m}$ de altura (63a, 63b e 63c) e no ambiente protegido controle com cortinas laterais abertas a $1,0 \mathrm{~m}$ de altura (63d, 63e e 63f) para os horários de 9:30h (63a e 63e), 12:30h (63b e 63f), 15:00h (63c e 63g) e 17:00h (63d e 63h) a 2,0m de altura no dia 29/02/00. O eixo x representa a largura (m) e y o comprimento do ambiente protegido (m).

Às 12:30h (Figuras 63b e 63f), a temperatura média do ar no perfil no ambiente protegido com abertura da cortina lateral a $2,5 \mathrm{~m}$ foi de $37,8^{\circ} \mathrm{C}$, enquanto que a temperatura média do ar no perfil no ambiente protegido com cortinas laterais abertas a $1,0 \mathrm{~m}$ foi de $42,8^{\circ} \mathrm{C}$, ou seja, houve redução de $11,7 \%$. Às 15:00h (Figuras 63c e 63f), a temperatura média do ar no perfil com cortinas laterais abertas a $2,5 \mathrm{~m}$ foi de $37,2^{\circ} \mathrm{C}$, enquanto que no ambiente protegido com cortinas laterais abertas a $1,0 \mathrm{~m}$ foi de $42,6^{\circ} \mathrm{C}$. A redução de temperatura do ar para esse perfil foi de 12,7\%. Às 17:00h (Figuras 63d e 
63h), a temperatura média do ar no perfil do ambiente protegido com cortinas abertas a $2,5 \mathrm{~m}$ foi de $31,7^{\circ} \mathrm{C}$ e no ambiente protegido com cortinas abertas a $1,0 \mathrm{~m}$, de $35,7^{\circ} \mathrm{C}$, representando redução de $11,2 \%$.

$\mathrm{O}$ ambiente protegido com cortinas laterais abertas a $2,5 \mathrm{~m}$ de altura teve temperaturas média do ar inferiores ao ambiente protegido com cortinas abertas a 1,0m de altura devido a sua maior área de abertura possibilitando melhor renovação do ar. A abertura de 2,5m de altura das cortinas laterais teve efeito na redução da temperatura do ar principalmente até a 2,0m de altura, enquanto que no ambiente protegido com cortinas abertas a 1,0m, esse efeito não pode ser visualizado. A distribuição de temperatura do ar nos ambientes protegidos foi bastante uniforme, principalmente a $0,5 \mathrm{~m}$ de altura e no ambiente protegido com cortinas abertas a $2,5 \mathrm{~m}$ de altura.

4.2.5.2. Abertura das cortinas laterais abertas a $2,5 \mathrm{~m}$ comparada com abertura da cortina lateral aberta a 1,0m de altura e nebulização.

\subsection{Variação da temperatura do ar.}

Estando com as cortinas laterais abertas no ambiente protegido E1 a 2,5m de altura e o ambiente protegido E2 a 1,0m de altura durante todo o dia, foi acionada a nebulização no período do dia de maior elevação da temperatura média do ar no ambiente protegido. A nebulização intermitente (15 minutos acionado e 15 minutos desligado) iniciou-se às 9:30h e terminou às 13:30h. Durante esse período de nebulização, nota-se a redução da temperatura média do ar, porém, em diferentes proporções, conforme a abertura das cortinas laterais. Na Figura 64 observa-se a redução da temperatura média do ar no ambiente protegido com cortinas abertas a 2,5m de altura e nebulização (E1) e a redução da temperatura do ar no ambiente protegido com cortinas abertas a 1,0m e nebulização (E2), no dia 06/03/00. A redução da temperatura do ar no

ambiente protegido com cortinas laterais abertas a 2,5m de altura e nebulização em comparação com o ambiente protegido com cortinas abertas a 1,0m de altura e nebulização foi significativa a 1,0\% de probabilidade pelo teste $t$. 


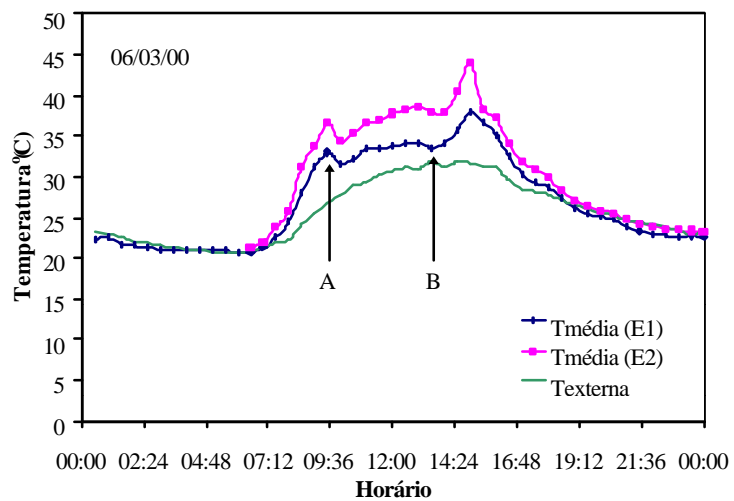

A - início da nebulização intermitente (9:30h)

B - final da nebulização $(13: 30 \mathrm{~h})$

Figura 64. Variação da temperatura média do ar no ambiente protegido com as cortinas laterais abertas a 2,5m e nebulização (E1), da temperatura média do ar no ambiente protegido protegidos com as cortinas laterais abertas a $1,0 \mathrm{~m}$ de altura e nebulização (E2) e no ambiente externo, no dia 06/03/00.

Durante o período com nebulização, a temperatura média do ar no ambiente protegido com cortinas laterais abertas a $2,5 \mathrm{~m}$ de altura (E1) foi de $33,3^{\circ} \mathrm{C}$ e a temperatura média do ar no ambiente protegido com cortinas laterais abertas a $1,0 \mathrm{~m}$ de altura (E2) foi de $37,0^{\circ} \mathrm{C}$. A diferença de temperatura foi de $3,7^{\circ} \mathrm{C}$, ou seja, a temperatura do ar no ambiente protegido E1 ficou 10,0\% abaixo da temperatura do ar no ambiente protegido E2. Nesse mesmo período, a temperatura média do ar externo foi de $29,8^{\circ} \mathrm{C}$. Assim, a temperatura média do ar no ambiente protegido E1 foi $11,8 \%$ superior à temperatura do ar no ambiente externo, bem como, a temperatura média do ar no ambiente protegido E2 foi $24,2 \%$ superior à temperatura do ar no ambiente externo. A umidade relativa média externa durante o período de nebulização foi de 62,6\% e a velocidade média do vento externo foi de $0,8 \mathrm{~m} / \mathrm{s}$.

Analisando o dia como um todo, temos que a temperatura média do ar diária no ambiente protegido $\mathrm{E} 1$ foi de $27,0^{\circ} \mathrm{C}$ e no ambiente protegido $\mathrm{E} 2$ foi de $31,0^{\circ} \mathrm{C}$. A diferença de $4,0^{\circ} \mathrm{C}$ representou uma diminuição da ordem de $12,9 \%$ na temperatura média do ar no ambiente protegido E1 em relação ao ambiente protegido E2. Como a temperatura média do ar externo foi de $25,7^{\circ} \mathrm{C}$, temos que a temperatura média do ar no ambiente protegido E1 e E2 ficaram 5,1\% e 20,7\% acima da mesma respectivamente. A 
umidade relativa média externa do ar nesse período foi de $8,6 \%$ e a velocidade do vento foi de $0,6 \mathrm{~m} / \mathrm{s}$.

Considerando somente o período do dia com luz, a temperatura média do ar no ambiente protegido $\mathrm{E} 1$ e $\mathrm{E} 2$ foi de $30,3^{\circ} \mathrm{C}$ e $33,2^{\circ} \mathrm{C}$, respectivamente. A diferença entre eles foi de $2,9^{\circ} \mathrm{C}$, ou $8,8 \%$. A temperatura média do ar externo nesse período foi de $27,7^{\circ} \mathrm{C}$. Assim, comparando a temperatura média do ar dos ambientes protegidos com a externa, E1 ficou 9,3\% superior e E2 ficou 19,9\% superior a temperatura do ar externa. A média diária de umidade relativa durante o período com luz foi de $61,5 \%$ e a velocidade do vento foi de $0,9 \mathrm{~m} / \mathrm{s}$.

$\mathrm{Na}$ Figura 65 observa-se a distribuição de temperatura do ar no ambiente protegido com cortinas laterais abertas a $2,5 \mathrm{~m}$ de altura (E1) e no ambiente protegido com cortinas abertas a 1,0m de altura (E2) durante o dia 08/03/00. A nebulização intermitente foi acionada às 9:30h e desligada às 13:30h.

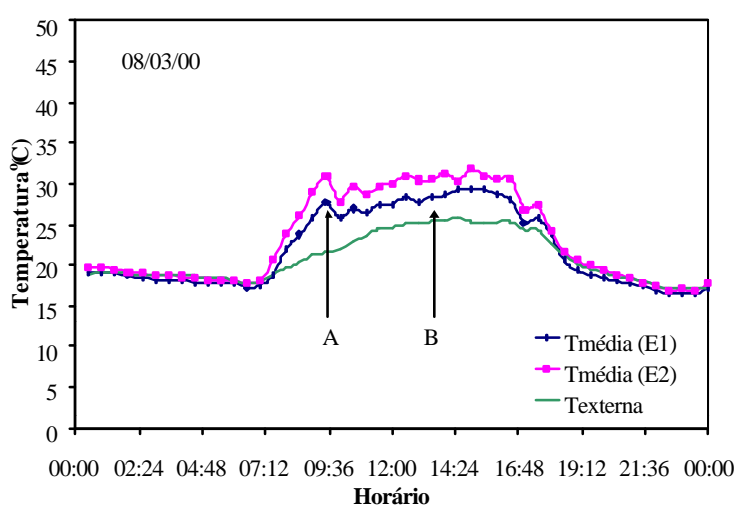

A - início da nebulização intermitente $(9: 30 \mathrm{~h})$

B - final da nebulização $(13: 30 \mathrm{~h})$

Figura 65. Variação da temperatura média do ar no ambiente protegido com as cortinas laterais abertas a 2,5m e nebulização (E1), da temperatura média do ar no ambiente protegido protegidos com as cortinas laterais abertas a $1,0 \mathrm{~m}$ de altura e nebulização (E2) e no ambiente externo, no dia 08/03/00.

A redução da temperatura do ar no ambiente protegido com cortinas laterais abertas a 2,5m de altura em comparação com o ambiente protegido com cortinas abertas a 1,0m de altura foi significativa a $1,0 \%$ de probabilidade pelo teste $t$. 
A temperatura média do ar durante a nebulização no ambiente protegido E1 foi de $27,4^{\circ} \mathrm{C}$ e no ambiente protegido $\mathrm{E} 2$ foi de $29,9^{\circ} \mathrm{C}$. Assim, o ambiente protegido E1 ficou com temperatura média do ar 8,4\% abaixo da temperatura do ar do ambiente protegido E2. A temperatura média do ar externa durante a nebulização foi de $23,9^{\circ} \mathrm{C}$ e, portanto, as cortinas laterais abertas e a nebulização não reduziram a temperatura do ar no ambiente protegido a níveis abaixo da temperatura do ar externa (Figuras 64 e 65), mas reduziu a valores próximos, chegando a porcentagens superiores de temperatura média do ar no ambiente protegido, em relação ao ambiente externo, de 14,7 e 25,2\%, em E1 e E2, respectivamente.

No dia 08/03/00 a velocidade média do vento durante a nebulização foi de $3,7 \mathrm{~m} / \mathrm{s}$, o que em parte responde o fato do dia ter havido valores menores de temperatura média do ar, tanto interna como externamente, bem como menor diferença entre a temperatura média do ar entre os ambientes protegidos. Segundo Feuilloley et al. (1990), independente do tamanho da abertura das janelas, a taxa de renovação de ar aumenta com a velocidade do vento. Assim, com valores maiores de velocidade do vento, a influência da altura de abertura da cortina lateral é menor, já que a ação do vento é mais efetiva na renovação do ar no ambiente protegido.

Considerando todo o dia, temos que a temperatura média do ar no ambiente protegido $\mathrm{E} 1$ foi de $22,0^{\circ} \mathrm{C}$ e a temperatura média do ar no ambiente protegido $\mathrm{E} 2$ foi de $23,3^{\circ} \mathrm{C}$. Assim, a temperatura média do ar no ambiente protegido E1 ficou 5,7\% menor que a temperatura do ar no ambiente E2. Comparando a temperatura do ar no ambiente protegido E1 e E2 com a temperatura média do ar externo (a qual foi de $20,9^{\circ} \mathrm{C}$ ), tem-se que a temperatura média do ar no ambiente protegido $\mathrm{E} 1$ ficou $5,4 \%$ maior que a temperatura média do ar externa e a temperatura média do ar no ambiente protegido E2 ficou $11,8 \%$ maior. A umidade relativa média diária foi de $84,3 \%$ e a velocidade média diária do vento foi de $3,2 \mathrm{~m} / \mathrm{s}$.

Considerando apenas o período do dia com lız, a temperatura média do ar no ambiente protegido $\mathrm{E} 1$ e $\mathrm{E} 2$ foram de $24,9^{\circ} \mathrm{C}$ e $26,8^{\circ} \mathrm{C}$, respectivamente. A diferença foi de $1,9^{\circ} \mathrm{C}$, ou $7,1 \%$. A temperatura média do ar externo nesse período foi de $22,6^{\circ} \mathrm{C}$. Assim, comparando a temperatura média do ar dos ambientes protegidos com a externa, 
E1 ficou 10,2\% superior e E2 ficou 18,6\%. A média diária de umidade relativa durante o período com luz foi de $78,8 \%$ e a velocidade do vento foi de $3,7 \mathrm{~m} / \mathrm{s}$.

\subsection{Variação vertical e horizontal de temperatura do ar.}

A Figura 66a apresenta o perfil vertical de distribuição de temperatura média do ar no dia 06/03/00 no ambiente protegido onde houve abertura da cortina lateral a 2,5m de altura ao nível do solo e nebulização e a Figura 66b apresenta o perfil vertical de distribuição de temperatura média do ar no ambiente protegido com as cortinas laterais abertas a 1,0m de altura em relação ao nível do solo e nebulização.
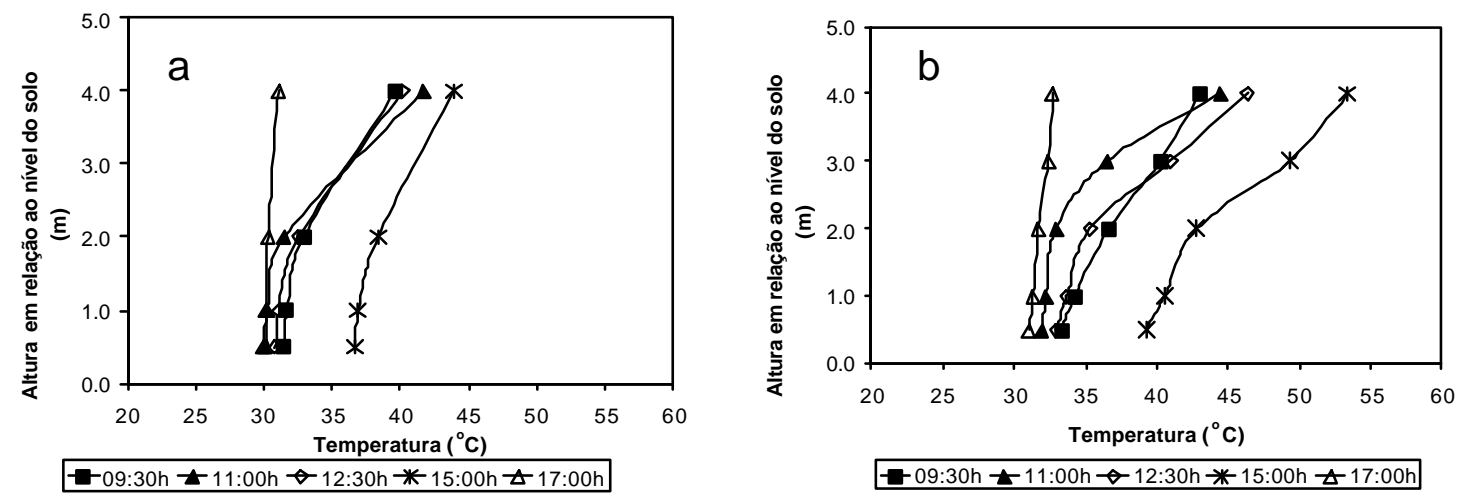

Figura 66. Perfil vertical de temperatura do ar no ambiente protegido com cortinas laterais abertas a 2,5m de altura e nebulização intermitente (a) e no ambiente protegido com cortinas laterais abertas a $1,0 \mathrm{~m}$ de altura e nebulização intermitente (b), às 9:30h, 11:00h, 12:30h, 15:00h e 17:00h, no dia 06/03/00.

Durante todo o decorrer do dia, a temperatura média do ar no ambiente protegido com as cortinas laterais abertas a 1,0m de altura, teve maior temperatura média do ar que $\mathrm{o}$ ambiente protegido com as cortinas laterais abertas a 2,5m.

Às 9:30h, no momento do início da nebulização, a temperatura média do ar no ambiente protegido (E1) no perfil vertical ao nível de $0,5 \mathrm{~m}$ foi de a $31,5^{\circ} \mathrm{C}$ (Figura $66 \mathrm{a}$ ), enquanto que no ambiente protegido com as cortinas abertas a 1,0m (Figura 66b) foi de $33,3^{\circ} \mathrm{C}$. A esse nível, a diferença de temperatura foi de $1,8^{\circ} \mathrm{C}$, ou $5,4 \%$. A $4,0 \mathrm{~m}$ de altura, a 
temperatura média do ar no perfil no ambiente protegido com cortinas a $2,5 \mathrm{~m}$ foi de $39,6^{\circ} \mathrm{C}$ e no ambiente protegido com cortinas abertas a $1,0 \mathrm{~m}$ foi de $43,0^{\circ} \mathrm{C}$, ou seja, $7,9 \%$ superior. A temperatura média do ar no perfil no ambiente com cortinas a $2,5 \mathrm{~m}$ foi de $33,9^{\circ} \mathrm{C}$ e no ambiente com cortinas a $1,0 \mathrm{~m}$ foi de $37,5^{\circ} \mathrm{C}$. $\mathrm{O}$ ambiente protegido com cortinas abertas a 2,5m ficou com temperatura do ar 9,6\% inferior a temperatura do ar no ambiente protegido com cortinas a 1,0m. No perfil de temperatura do ar vertical determinado no ambiente protegido com cortinas abertas a 2,5m de altura houve menor elevação de temperatura do ar até a altura de 2,0m devido a abertura das cortinas laterais. Acima dessa altura, a temperatura do ar se elevou. Já no perfil vertical de temperatura do ar, determinado no ambiente protegido com cortinas abertas a 1,0m de altura a elevação da temperatura do ar ocorreu com a elevação do ponto de determinação da temperatura do ar, sem apresentar o efeito observado na Figura 66a. No perfil determinado às 11:00h, o ambiente protegido com cortinas abertas a 2,5m de altura e nebulização apresentava temperatura média do ar a $0,5 \mathrm{~m}$ de altura de $30,1^{\circ} \mathrm{C}$ e a $4,0 \mathrm{~m}$ de altura de $41,7^{\circ} \mathrm{C}$, com temperatura média do ar no perfil de $33,4^{\circ} \mathrm{C}$. No ambiente protegido com cortinas abertas a $1,0 \mathrm{~m}$ de altura e nebulização, para o nível de $0,5 \mathrm{~m}$, a temperatura do ar foi de $31,9^{\circ} \mathrm{C}$ e para o nível de $4,0 \mathrm{~m}$ foi de $44,4^{\circ} \mathrm{C}$, com temperatura média do ar de $35,6^{\circ} \mathrm{C}$. A redução de temperatura foi de $6,2 \%$. Em todos os perfis verticais determinados, observou-se o aumento da temperatura média do ar com o aumento na altura de coleta de dados, nos ambientes protegidos, chegando a temperatura do ar máxima a 4,0m, no ponto mais alto no ambiente protegido e próximo da cobertura plástica, conforme visto anteriormente. A abertura de 2,5m de altura das cortinas laterais e a nebulização tiveram efeito na redução de temperatura do ar principalmente até a 2,0m de altura, enquanto que no ambiente protegido com cortinas abertas a 1,0m, esse efeito não pode ser visualizado. Entretanto, após o início da nebulização, a redução no gradiente de temperatura do ar nos níveis inferiores a 3,0m de altura que correspondente à instalação do sistema de nebulização, pôde ser observado, com elevação da temperatura do ar ao nível de 4,0m de altura. Às 12:30h, no ambiente protegido com cortinas a $2,5 \mathrm{~m}$ e nebulização a temperatura média do ar a $0,5 \mathrm{~m}$, foi de $30,9^{\circ} \mathrm{C}$ e a $4,0 \mathrm{~m}$ de $40,1^{\circ} \mathrm{C}$ com temperatura média do ar no perfil de $33,6^{\circ} \mathrm{C}$. No ambiente protegido com cortinas a $1,0 \mathrm{~m}$ e nebulização, a temperatura média do ar $0,5 \mathrm{~m}$ foi de $32,9^{\circ} \mathrm{C}$ e a $4,0 \mathrm{~m}$ 
foi de $46,4^{\circ} \mathrm{C}$, com temperatura média do ar no perfil de $37,8^{\circ} \mathrm{C}$. A temperatura média do ar no perfil no ambiente protegido com cortinas abertas a $2,5 \mathrm{~m}$ ficou $11,1 \%$ inferior. Às 15:00h, após o final da nebulização, a temperatura média do ar no perfil vertical no ambiente protegido com cortinas abertas a $2,5 \mathrm{~m}$ foi de $39,0^{\circ} \mathrm{C}$, com temperatura média de $36,7^{\circ} \mathrm{C}$ a $0,5 \mathrm{~m}$ e de $44,0^{\circ} \mathrm{C}$ a $4,0 \mathrm{~m}$ de altura, enquanto que a temperatura média do ar no perfil no ambiente protegido com cortinas abertas a $1,0 \mathrm{~m}$ foi de $45,0^{\circ} \mathrm{C}$, com temperatura média de $39,2^{\circ} \mathrm{C}$ a $0,5 \mathrm{~m}$ e de $53,4^{\circ} \mathrm{C}$ a $4,0 \mathrm{~m}$ de altura. A redução de temperatura média do ar no perfil de temperatura do ar foi de 13,3\%. Às 17:00h a temperatura média do ar no perfil vertical no ambiente protegido com cortinas abertas a $2,5 \mathrm{~m}$ foi de $30,4^{\circ} \mathrm{C}$, com temperatura média de $30,0^{\circ} \mathrm{C}$ a $0,5 \mathrm{~m}$ e de $31,1^{\circ} \mathrm{C}$ a $4,0 \mathrm{~m}$ de altura e a temperatura média do ar no perfil vertical no ambiente protegido com cortinas a $1,0 \mathrm{~m}$ foi de $31,8^{\circ} \mathrm{C}$, com temperatura média de $31,0^{\circ} \mathrm{C}$ a $0,5 \mathrm{~m}$ e $32,7^{\circ} \mathrm{C}$ a $4,0 \mathrm{~m}$, representando uma redução média de temperatura de $4,4 \%$.

Na Figura 67 estão representas as isotermas a 0,5m de altura no dia 06/03/00 para o ambiente protegido com cortinas laterais abertas a 2,5m e nebulização (67a, 67b e 67c) e o ambiente protegido com cortinas laterais abertas a 1,0m de altura e nebulização (67d, 67e e 67f) para os horários de 9:30h (67a e 67e), 12:30h (67b e 67f), 15:00h (67c e 67g) e 17:00h (67d e 67h).

No momento do início da nebulização nos ambientes protegidos, as 9:30h (Figuras 67a e 67e) a variação de temperatura do ar nos ambientes protegidos foi de $1,0^{\circ} \mathrm{C}$, com distribuição de temperaturas homogênea. Nesse horário, a velocidade do vento foi de $0,013 \mathrm{~m} / \mathrm{s}$, na direção leste. A temperatura média do ar no perfil horizontal foi de 31,7 e $32,7^{\circ} \mathrm{C}$ para o ambiente protegido com cortinas laterais abertas a $2,5 \mathrm{~m}$ e com cortinas laterais abertas a 1,0m, respectivamente, ou seja, a temperatura do ar no ambiente protegido com cortinas abertas a $2,5 \mathrm{~m}$ ficou $3,1 \%$ inferior a no ambiente protegido com cortinas a $1,0 \mathrm{~m}$. 

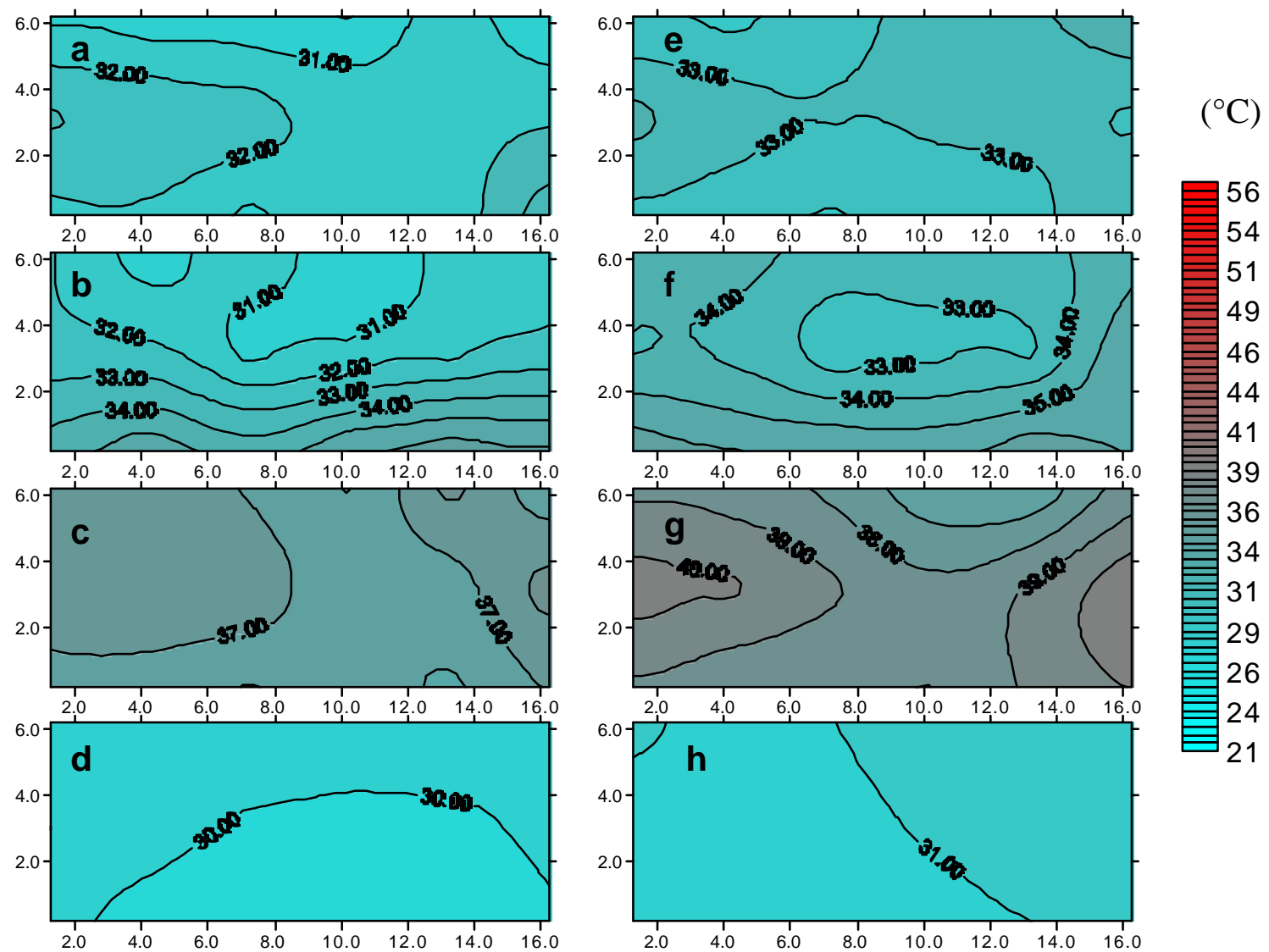

Figura 67. Distribuição de temperatura do ar no ambiente protegido com cortinas laterais abertas a 2,5m de altura e nebulização (67a, 67b e 67c) e no ambiente protegido com cortinas laterais abertas a $1,0 \mathrm{~m}$ de altura e nebulização $(67 \mathrm{~d}$, 67e e 67f) para os horários de 9:30h (67a e 67e), 12:30h (67b e 67f), 15:00h (67c e $67 \mathrm{~g}$ ) e 17:00h (67d e 67h) a 0,5m de altura no dia 06/03/00. O eixo x representa a largura (m) e y o comprimento do ambiente protegido (m).

Às 12:30h, as temperaturas médias do ar no ambiente protegido com as cortinas laterais abertas a 2,5m de altura e nebulização (Figura 67b) e ambiente protegido com cortinas laterais abertas a 1,0m de altura e nebulização (Figura 67f) tiveram distribuição de temperatura do ar com menor temperatura do ar no lado norte no ambiente protegido evidenciando a direção predominante do vento $(1,75 \mathrm{~m} / \mathrm{s}$, direção nordeste). A temperatura média do ar no perfil no ambiente protegido com cortinas laterais abertas a $2,5 \mathrm{~m}$ e nebulização foi de $32,7^{\circ} \mathrm{C}$, enquanto que a temperatura média do ar no perfil no 
ambiente protegido com cortinas abertas a $1,0 \mathrm{~m}$ e nebulização foi de $34,9^{\circ} \mathrm{C}$. A temperatura média do ar no perfil, com cortinas laterais abertas a 2,5m, ficou $6,3 \%$ abaixo da temperatura média do ar no perfil com cortinas abertas a 1,0m. Às 15:00h as temperaturas médias do ar foi de 36,9 e $38,9^{\circ} \mathrm{C}$, para o ambiente (E1) (Figura 67c) e ambiente com cortinas laterais abertas a 1,0m e nebulização (Figura 67g), respectivamente, proporcionando redução de 5,1\%. A velocidade do vento nesse período foi de 1,38m/s, na direção nordeste. Nas Figuras 67d e 67h estão representadas as distribuições horizontais de temperatura do ar no ambiente protegido (E1) e ambiente protegido com cortinas laterais abertas a $1,0 \mathrm{~m}$ respectivamente. A distribuição de temperatura do ar nos ambientes protegidos foram semelhantes, porém, com temperatura média do ar no perfil de 30,1 e $31,0^{\circ} \mathrm{C}$, respectivamente. A redução de temperatura do ar foi de $2,9 \%$. A velocidade do vento foi de $1,6 \mathrm{~m} / \mathrm{s}$, na direção sudoeste.

$\mathrm{Na}$ Figura 68 estão representas as isotermas a 2,0m de altura no dia 06/03/00 para o ambiente protegido (E1) e nebulização (68a, 68b e 68c) e o ambiente protegido com cortinas laterais abertas a 1,0m de altura e nebulização (68d, 68e e 68f) para os horários de 9:30h (68a e 68e), 12:30h (68b e 68f), 15:00h (68c e 68g) e 17:00h (68d e $68 h)$.

Às 9:30h (Figuras 68a e 68e) a variação de temperatura do ar nos diferentes pontos de amostragem nos ambientes protegidos foi de $1,0^{\circ} \mathrm{C}$. A temperatura média do ar no perfil no ambiente protegido com cortinas laterais abertas a $2,5 \mathrm{~m}$ foi de $33,1^{\circ} \mathrm{C}$ e para o ambiente protegido com cortinas laterais abertas a $1,0 \mathrm{~m}$ foi de $36,7^{\circ} \mathrm{C}$. A temperatura do ar no ambiente protegido com cortinas abertas a 2,5m foi 9,8\% inferior a temperatura do ar no ambiente protegido com cortinas abertas a 1,0m. Às 12:30h (Figuras 68b e 68f), a temperatura média do ar no perfil no ambiente protegido com abertura da cortina lateral a $2,5 \mathrm{~m}$ e nebulização foi de $33,9^{\circ} \mathrm{C}$, enquanto que a temperatura média do ar no perfil no ambiente protegido com cortinas laterais abertas a $1,0 \mathrm{~m}$ e nebulização foi de $37,9^{\circ} \mathrm{C}$, ou seja, houve redução de $10,6 \%$. Com a nebulização houve formação de zonas centrais no ambiente protegido com temperaturas menores e aumentando a medida que se afasta do centro. 

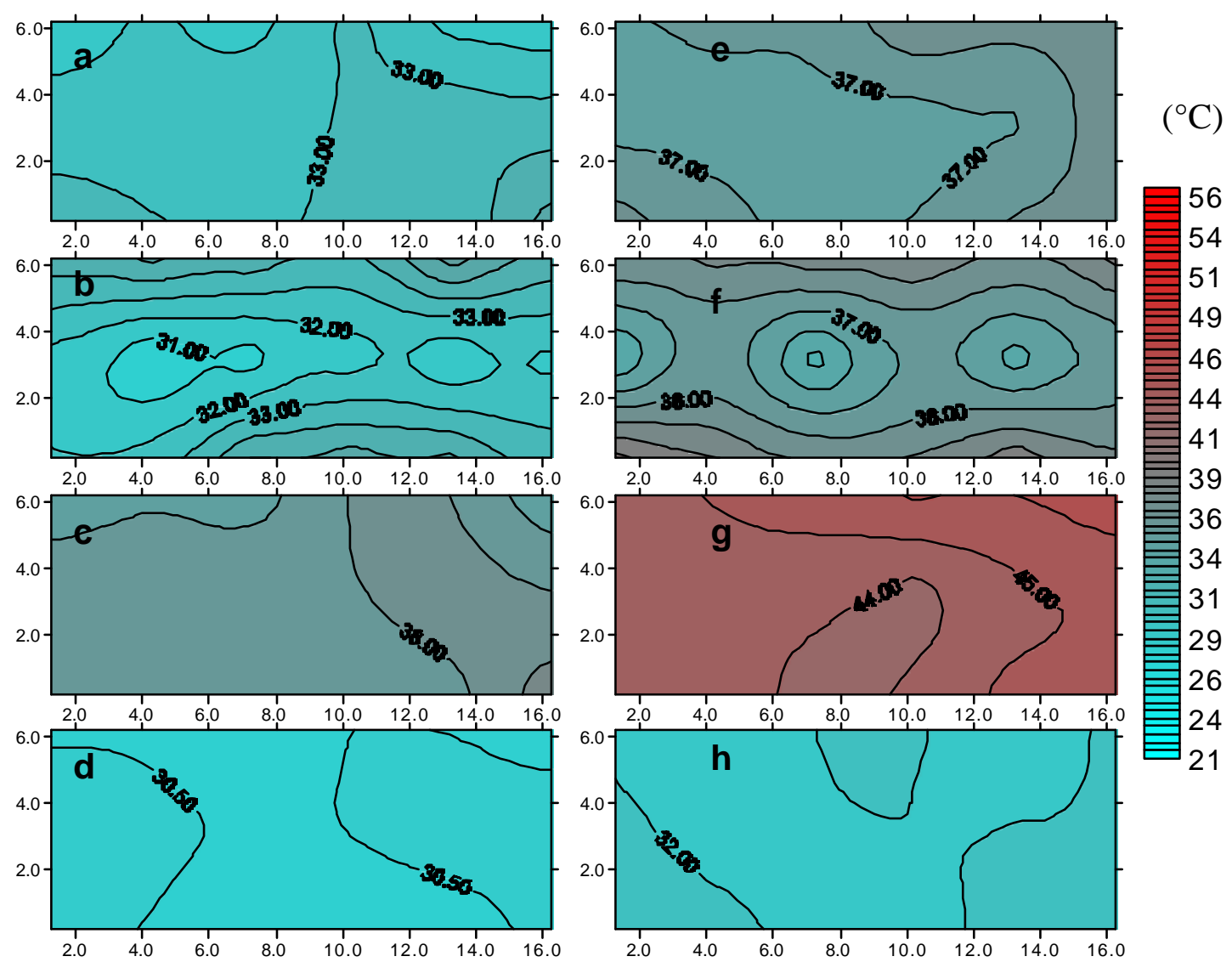

Figura 68. Distribuição de temperatura do ar no ambiente protegido com cortinas laterais abertas a $2,5 \mathrm{~m}$ de altura (68a, 68b e 68c) e no ambiente protegido controle com cortinas laterais abertas a $1,0 \mathrm{~m}$ de altura (68d, 68e e 68f) para os horários de 9:30h (68a e 68e), 12:30h (68b e 68f), 15:00h (68c e 68g) e 17:00h (68d e 68h) a 2,0m de altura no dia 29/02/00. O eixo x representa a largura (m) e y o comprimento do ambiente protegido (m).

Às 15:00h (Figuras 68c e 68f), a temperatura média do ar no perfil com cortinas laterais abertas a $2,5 \mathrm{~m}$ foi de $37,8^{\circ} \mathrm{C}$, enquanto que no ambiente protegido com cortinas laterais abertas a $1,0 \mathrm{~m}$ e foi de $43,9^{\circ} \mathrm{C}$. A redução de temperatura do ar para esse perfil foi de $13,9 \%$. Às 17:00h (Figuras 68d e 68h), a temperatura média do ar no perfil no ambiente protegido com cortinas abertas a $2,5 \mathrm{~m}$ foi de $30,5^{\circ} \mathrm{C}$ e no ambiente protegido com cortinas abertas a $1,0 \mathrm{~m}$, de $31,9^{\circ} \mathrm{C}$, representando redução de $4,4 \%$. 
No manejo com abertura de cortinas laterais à diferentes alturas e nebulização, durante a nebulização dos ambientes protegidos houve a redução da temperatura média do ar por efeito da transformação do calor sensível do ar para calor latente de vaporização. Porém, a diferença de redução de temperatura entre um ambiente e outro se manteve praticamente a mesma daquela ocorrida entre os ambientes protegidos cujo manejo constituiu somente das diferentes aberturas das cortinas laterais, sem nebulização (Figuras 59 e 60).

\subsubsection{Efeito da utilização de água resfriada na nebulização.}

Para melhor visualizar o efeito da nebulização com água resfriada, utilizou-se medidas armazenadas a cada minuto pelos sistemas de aquisição de dados. A nebulização foi intermitente das 12:00 às 12:30h.

A Figura 69 apresenta a comparação entre as temperaturas médias dos ambientes protegidos com nebulização, sendo que, no ambiente protegido E1 a temperatura da água nebulizada estava à temperatura ambiente $\left(21,0^{\circ} \mathrm{C}\right)$ e no ambiente protegido E2 a temperatura da água foi de $4,3^{\circ} \mathrm{C}$, durante o dia $28 / 04 / 00$. A diferença entre as temperaturas de água nebulizada foi de $16,7^{\circ} \mathrm{C}$. A temperatura média do ar no ambiente protegido nebulizado com água à temperatura ambiente durante a nebulização foi de $39,7^{\circ} \mathrm{C}$ enquanto que a temperatura média do ar no ambiente protegido nebulizado com água resfriada foi de $38,9^{\circ} \mathrm{C}$, ou $0,8^{\circ} \mathrm{C}$ de diferença entre as temperaturas do ar, ou seja, 2,0\%. O teste t não foi significativo e, portanto, não houve diferença estatística entre as médias. 


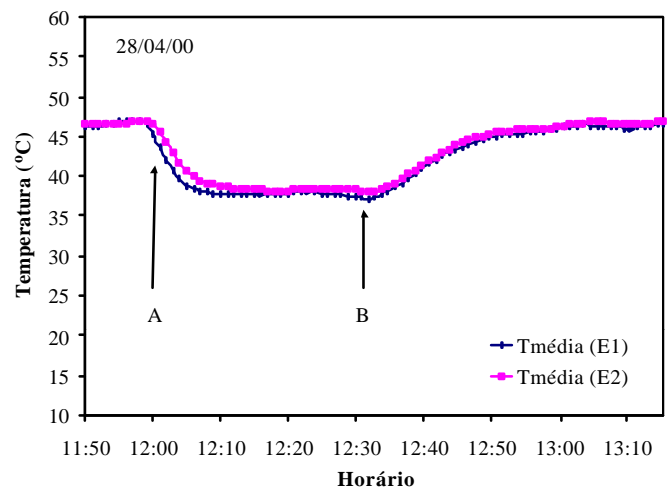
A $\quad-\quad$ início da nebulização (12:00h)

B - final da nebulização

Figura 69. Comparação entre as temperaturas médias do ar no ambiente protegido com nebulização a temperatura ambiente (E2) e no ambiente com nebulização com água resfriada (E1), durante o dia 28/04/00;

A Figura 70 apresenta a comparação entre as temperaturas médias do ar dos ambientes protegidos com nebulização, sendo que, no ambiente protegido E1 a temperatura da água nebulizada estava à temperatura ambiente de $24,0^{\circ} \mathrm{C}$ e no ambiente protegido E2 a temperatura da água foi de $4,9^{\circ} \mathrm{C}$, durante o dia $03 / 05 / 00$. A diferença entre as temperaturas de água nebulizada foi de $19,1^{\circ} \mathrm{C}$. A temperatura média do ar no ambiente protegido nebulizado com água à temperatura ambiente durante a nebulização foi de $42,8^{\circ} \mathrm{C}$ enquanto que a temperatura média do ar no ambiente protegido nebulizado com água resfriada foi de $42,1^{\circ} \mathrm{C}$, ou seja, $0,7^{\circ} \mathrm{C}$ de diferença, ou $1,6 \%$. O teste $\mathrm{t}$ não foi significativo e, portanto, não houve diferença estatística entre as médias.

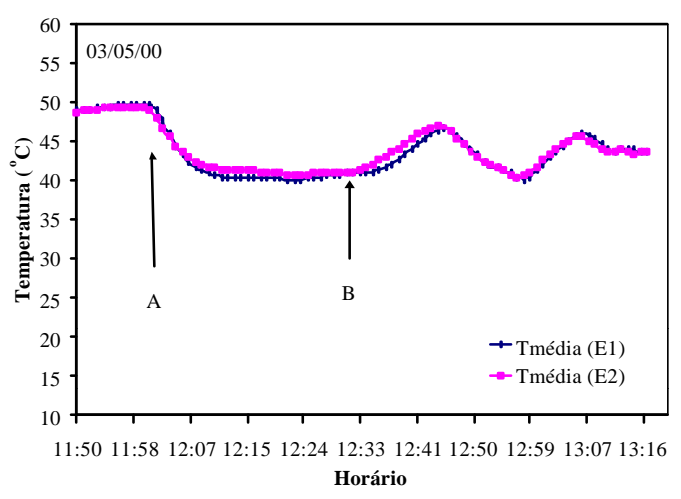

A - início da nebulização

B - final da nebulização

Figura 70. Comparação entre as temperaturas médias do ar no ambiente protegido com nebulização a temperatura ambiente (E2) e no ambiente com nebulização com água resfriada (E1), durante o dia 03/05/00. 
De acordo com Pereira et al. (1997), o calor latente de evaporação é dependente da temperatura da água e é dado pela equação:

$$
\mathrm{L}=(-2497-2,37 \mathrm{~T}) / 1000
$$

\section{Em que:}

$\mathrm{L}=$ calor latente de evaporação $(\mathrm{MJ} / \mathrm{kg})$;

$\mathrm{T}=$ temperatura da água $\left({ }^{\circ} \mathrm{C}\right)$.

Assim, se a água estiver com $20,0^{\circ} \mathrm{C}$ serão necessários $2,45 \mathrm{MJ}$ para evaporar $1,0 \mathrm{~kg}$ de água e se ela estiver a $5,0^{\circ} \mathrm{C}$ serão necessários $2,48 \mathrm{MJ}$. Como a diferença de calor latente necessário para evaporar $1,0 \mathrm{~kg}$ de água a $20,0^{\circ} \mathrm{C}$ e a $5,0^{\circ} \mathrm{C}$ é pequena, mesmo com grandes gradientes de temperatura da água, a utilização de água resfriada na nebulização teve pequena contribuição na redução da temperatura do ar.

\subsection{Resultados obtidos.}

A Tabela 3 apresenta as taxas de redução de temperatura do ar e os diferentes manejos executados obtidas no experimento. 
Tabela 3. Taxas de redução de temperatura do ar obtidas pelos diferentes manejos executados.

\begin{tabular}{|c|c|c|c|}
\hline Ambiente manejado & Ambiente controle & Data & $\begin{array}{l}\text { \% taxas } \\
\text { (reduções) }\end{array}$ \\
\hline $\begin{array}{l}\text { - Abertura das cortinas laterais a } 2,5 \mathrm{~m} \\
\text { de altura ( } 9 \text { as } 16: 00 \mathrm{~h})\end{array}$ & - Cortinas laterais fechadas & $23 / 11 / 99$ & $24,2 \%\left(11,4^{\circ} \mathrm{C}\right)$ \\
\hline $\begin{array}{l}\text { - Abertura das cortinas laterais a } 2,0 \mathrm{~m} \\
\text { de altura e abertura da cortina zenital } \\
\text { (11 as } 14: 00 \mathrm{~h})\end{array}$ & - Cortinas laterais fechadas & $30 / 11 / 99$ & $18,2 \%\left(8,9^{\circ} \mathrm{C}\right)$ \\
\hline $\begin{array}{l}\text { - Cortinas laterais e zenital fechadas e } \\
\text { nebulização ( } 9 \text { as 16:00h) }\end{array}$ & - Cortinas laterais fechadas & 07/11/99 & $17,6 \%\left(9,0^{\circ} \mathrm{C}\right)$ \\
\hline $\begin{array}{l}\text { - Cortinas laterais e zenital fechadas e } \\
\text { nebulização (11 as 15:30h) }\end{array}$ & - Cortinas laterais fechadas & $17 / 11 / 99$ & $17,3 \%\left(8,7^{\circ} \mathrm{C}\right)$ \\
\hline $\begin{array}{l}\text { - Cortinas laterais abertas a } 2,5 \mathrm{~m}(24 \mathrm{~h}) \text {, } \\
\text { zenitais fechadas e nebulização ( } 9 \text { as }\end{array}$ & $\begin{array}{l}\text { - Cortinas laterais abertas a } \\
2,5 \mathrm{~m}(24 \mathrm{~h}) \text { e zenitais }\end{array}$ & $02 / 11 / 99$ & $13,1 \%\left(4,3^{\circ} \mathrm{C}\right)$ \\
\hline $15: 30 \mathrm{~h})$ & fechadas & & \\
\hline $\begin{array}{l}\text { - Cortinas laterais abertas a 2,5m ( } 24 \mathrm{~h}) \text {, } \\
\text { zenitais fechadas e nebulização ( } 9 \text { as }\end{array}$ & $\begin{array}{l}\text { - Cortinas laterais abertas a } \\
2,5 \mathrm{~m}(24 \mathrm{~h}) \text { e zenitais }\end{array}$ & 03/11/99 & $15,3 \%\left(5,3^{\circ} \mathrm{C}\right)$ \\
\hline $15: 30 \mathrm{~h})$ & fechadas & & \\
\hline $\begin{array}{l}\text { - Abertura das cortinas laterais a } 1,0 \mathrm{~m} \text { e } \\
\text { nebulização ( } 9 \text { as } 15: 00 \mathrm{~h})\end{array}$ & - Cortinas laterais fechadas & $04 / 11 / 99$ & $29,7 \%\left(14,0^{\circ} \mathrm{C}\right)$ \\
\hline $\begin{array}{l}\text { - Abertura das cortinas zenital e laterais } \\
\text { a } 1,0 \mathrm{~m} \text { e nebulização (10:45 as } 14: 30 \mathrm{~h})\end{array}$ & - Cortinas laterais fechadas & $01 / 12 / 99$ & $28,5 \%\left(12,9^{\circ} \mathrm{C}\right)$ \\
\hline $\begin{array}{l}\text { - Abertura das cortinas laterais a 2,0m e } \\
\text { nebulização ( } 9 \text { as } 15: 30 \mathrm{~h} \text { ) }\end{array}$ & - Cortinas laterais fechadas & 08/11/99 & $31,3 \%\left(15,2^{\circ} \mathrm{C}\right)$ \\
\hline $\begin{array}{l}\text { - Abertura das cortinas zenital e laterais } \\
\text { a } 2,0 \mathrm{~m} \text { e nebulização (10:45 as } 16: 30 \mathrm{~h})\end{array}$ & - Cortinas laterais fechadas & $02 / 12 / 99$ & $24,7 \%\left(12,4^{\circ} \mathrm{C}\right)$ \\
\hline $\begin{array}{l}\text {-Cortinas laterais abertas a } 0,5 \mathrm{~m} \mathrm{e} \\
\text { abertura da janela zenital ( } 11 \text { as } 15: 00 \mathrm{~h})\end{array}$ & $\begin{array}{l}\text { - Cortinas laterais abertas a } \\
0,5 \mathrm{~m}\end{array}$ & $23 / 04 / 00$ & $15,6 \%\left(6,6^{\circ} \mathrm{C}\right)$ \\
\hline $\begin{array}{l}\text { - Cortinas laterais abertas a } 0,5 \mathrm{~m} \mathrm{e} \\
\text { abertura da janela zenital ( } 11 \text { as } 15: 00 \mathrm{~h})\end{array}$ & $\begin{array}{l}\text { - Cortinas laterais abertas a } \\
0,5 \mathrm{~m}\end{array}$ & $24 / 04 / 00$ & $14,2 \%\left(6,2^{\circ} \mathrm{C}\right)$ \\
\hline $\begin{array}{l}\text { - Cortinas laterais abertas a 1,0m e } \\
\text { abertura da janela zenital ( } 11 \text { as } 15: 00 \mathrm{~h})\end{array}$ & $\begin{array}{l}\text { - Cortinas laterais abertas a } \\
1,0 \mathrm{~m}\end{array}$ & 05/04/00 & $12,0 \%\left(4,7^{\circ} \mathrm{C}\right)$ \\
\hline
\end{tabular}


Tabela 3. Continuação.

\begin{tabular}{|c|c|c|c|}
\hline Ambiente manejado & Ambiente controle & Data & $\begin{array}{l}\text { \% taxas } \\
\text { (reduções) }\end{array}$ \\
\hline $\begin{array}{l}\text { - Cortinas laterais abertas a } 1,0 \mathrm{~m} \mathrm{e} \\
\text { abertura da janela zenital (11 as 15:00h) }\end{array}$ & $\begin{array}{l}\text { - Cortinas laterais abertas a } \\
1,0 \mathrm{~m}\end{array}$ & $08 / 04 / 00$ & $11,3 \%\left(4,7^{\circ} \mathrm{C}\right)$ \\
\hline $\begin{array}{l}\text { - Cortinas laterais abertas a } 2,0 \mathrm{~m} \mathrm{e} \\
\text { abertura da janela zenital (11 as 15:00h) }\end{array}$ & $\begin{array}{l}\text { - Cortinas laterais abertas a } \\
2,0 \mathrm{~m}\end{array}$ & $12 / 04 / 00$ & $4,6 \%\left(1,8^{\circ} \mathrm{C}\right)$ \\
\hline $\begin{array}{l}\text { - Cortinas laterais abertas a } 2,0 \mathrm{~m} \mathrm{e} \\
\text { abertura da janela zenital (11 as 15:00h) }\end{array}$ & $\begin{array}{l}\text { - Cortinas laterais abertas a } \\
2,0 \mathrm{~m}\end{array}$ & $15 / 04 / 00$ & $5,8 \%\left(2,2^{\circ} \mathrm{C}\right)$ \\
\hline $\begin{array}{l}\text { - Cortinas laterais abertas a } 3,0 \mathrm{~m} \mathrm{e} \\
\text { abertura da janela zenital (11 as 15:00h) }\end{array}$ & $\begin{array}{l}\text { - Cortinas laterais abertas a } \\
3,0 \mathrm{~m}\end{array}$ & $18 / 04 / 00$ & $3,0 \%\left(0,9^{\circ} \mathrm{C}\right)$ \\
\hline $\begin{array}{l}\text { - Cortinas laterais abertas a } 3,0 \mathrm{~m} \mathrm{e} \\
\text { abertura da janela zenital (11 as 15:00h) }\end{array}$ & $\begin{array}{l}\text { - Cortinas laterais abertas a } \\
3,0 \mathrm{~m}\end{array}$ & $19 / 04 / 00$ & $1,9 \%\left(0,6^{\circ} \mathrm{C}\right)$ \\
\hline - Cortinas laterais abertas a $2,5 \mathrm{~m}$ & $\begin{array}{l}\text { - Cortinas laterais abertas a } \\
1,0 \mathrm{~m}\end{array}$ & $24 / 02 / 00$ & $7,7 \%\left(2,3^{\circ} \mathrm{C}\right)$ \\
\hline - Cortinas laterais abertas a $2,5 \mathrm{~m}$ & $\begin{array}{l}\text { - Cortinas laterais abertas a } \\
1,0 \mathrm{~m}\end{array}$ & $29 / 02 / 00$ & $8,9 \%\left(2,6^{\circ} \mathrm{C}\right)$ \\
\hline $\begin{array}{l}\text { - Cortinas laterais abertas a 2,5m e } \\
\text { nebulização ( } 9: 30 \text { as 13:30h) }\end{array}$ & $\begin{array}{l}\text { - Cortinas laterais abertas a } \\
1,0 \mathrm{~m} \text { e nebulização }\end{array}$ & 06/03/00 & $10,0 \%\left(3,7^{\circ} \mathrm{C}\right)$ \\
\hline $\begin{array}{l}\text { - Cortinas laterais abertas a } 2,5 \mathrm{~m} \mathrm{e} \\
\text { nebulização ( } 9: 30 \text { as } 13: 30 \mathrm{~h})\end{array}$ & $\begin{array}{l}\text { - Cortinas laterais abertas a } \\
1,0 \mathrm{~m} \text { e nebulização }\end{array}$ & 08/03/00 & $8,4 \%\left(2,5^{\circ} \mathrm{C}\right)$ \\
\hline - Água resfriada $\left(4,3^{\circ} \mathrm{C}\right)$ & $\begin{array}{l}\text { - Água a temperatura } \\
\text { ambiente }\left(21,0^{\circ} \mathrm{C}\right)\end{array}$ & $28 / 04 / 00$ & $2,0 \%\left(0,8^{\circ} \mathrm{C}\right)$ \\
\hline - Água resfriada $\left(4,9^{\circ} \mathrm{C}\right)$ & $\begin{array}{l}\text { - Água a temperatura } \\
\text { ambiente }\left(24,0^{\circ} \mathrm{C}\right)\end{array}$ & $03 / 05 / 00$ & $1,6 \%\left(0,7^{\circ} \mathrm{C}\right)$ \\
\hline
\end{tabular}




\section{CONCLUSÕES}

- Efeito do manejo de cortinas e nebulização no ambiente protegido.

A nebulização em ambientes protegidos mostrou-se eficaz no processo de redução de temperaturas do ar durante o seu acionamento. A combinação do manejo de cortinas e nebulização foi o sistema mais eficiente na redução de temperatura do ar e pode reduzir a temperatura do ar no ambiente protegido a níveis muito próximos à temperatura do ar externa e em alguns casos a temperaturas abaixo da mesma.

- Efeito da abertura de cortinas zenitais, com diferentes alturas de abertura de cortinas laterais.

O efeito na redução de temperatura média do ar no ambiente protegido causado pela abertura da janela zenital foi maior com a menor abertura das cortinas laterais devido ao processo convectivo ou "efeito termo-sifão". A distribuição da temperatura média do ar no ambiente protegido com as cortinas laterais abertas a 3,0m de altura praticamente não foi modificada pela abertura da cortina zenital, principalmente quando a velocidade de vento externo era elevada. O efeito da janela zenital foi mais pronunciado com abertura de cortinas laterais a $0,5 \mathrm{~m}$ de altura, quando ocorria menor fluxo de ar pelo manejo de cortinas laterais e maior efeito do processo convectivo.

- Variação vertical e horizontal de temperatura do ar em ambientes protegidos.

A análise da distribuição da temperatura do ar por meio de isotermas permitiu uma visão global instantânea do processo de redução de temperatura do ar. As isotermas confirmam o fato de que a distribuição de temperatura do ar no ambiente protegido não é homogênea e a escolha do local ideal para instalação de sensores e equipamentos de 
coleta de dados é muito importante para a obtenção dos dados mais representativos das condições micrometeorológicas do ambiente protegido. 


\section{REFERÊNCIAS BIBLIOGRÁFICAS}

ABREU, P. G. de; ABREU, V. M. N.; MAZZUCO, H. Uso do resfriamento evaporativo (adiabático) na criação de frangos de corte. Concórdia: EMBRAPA-CNPSA, 1999. 51p. (EMBRAPA-CNPSA. Documentos, 59).

AL-JAMAL, K. Greenhouse cooling in hot countries. Energy, v. 19, n.11, p. 1187$1192,1994$.

AL-RIAHI, M.; AL-KARAGHOULI.; HASSON, A. W. Relations between radiation fluxes of a greenhouse in semi-arid conditions. Agricultural and Forest Meteorology, n.44, p. 329-338, 1989.

ALPI, A.; TOGNONI, F. Cultivo en invernadero. 3.ed. Madrid: Mundi-Prensa, 1991. $347 \mathrm{p}$.

ANDRIOLO, J. L. Fisiologia das culturas protegidas. Santa Maria: Ed. da UFSM, 1999. 142p.

ASBONO, M; MARTINEZ, S.; GARBI, M. Distribución vertical de las unidades caloricas en tomate LV (Lycopersicon sculentum) conducidos bajo cobertura plástica. In: CONGRESSO BRASILEIRO DE AGROMETEOROLOGIA, 10, Piracicaba, SP. Anais. Piracicaba: Sociedade Brasileira de Agrometeorologia. p.1214, 1997. (13 a 18 de jul. 1997).

ASHRAE. Equipment Handbook. New York: American Society of Heating, Refrigerating, and Air-Conditioning Engeneers. 1983. 
BAÊTA , F. C.; SOUZA, C. F. Ambiência em edificações rurais - conforto animal. Viçosa: UFV, 1997. 246p.

BAETEN, S.; VERLODT, H.; EL FAHEN, S.; HARBAOUI, Y. Visualization of temperature distribution in $\mathrm{PE}$ greenhouses with static aeration. Acta Horticulturae, v. 170, p.173-184, 1985.

BLISKA Jr., A.; HONÓRIO, S. L. Plasticultura e estufa. Campinas: UNICAMP/Faculdade de engenharia agrícola, 1996. 85p.

BOTTCHER, R. W.; BAUGHMAN, G. R.; GATES, R. S.; TIMMONS, M. B. Characterizing efficiency of misting systems for poultry. Transactions of the ASAE, v.34, n.2, p.586-590, 1991.

BURIOL, G. A.; SCHNEIDER, F.M.; ESTEFANEL, V.; ANDRIOLO, J. L.; MEDEIROS, S. L.P. Modificação na temperatura mínima do ar causada por estufas de polietileno transparente de baixa densidade. Revista Brasileira de Agrometeorologia, v.1, p.43-49, 1993.

BURIOL, G. A.; HELDWEIN, A. B.; STRECK, N. A.; SCHNEIDER, F. M.; ESTEFANEL, V.; DALMAGO, G. A. Gradiente vertical de temperatura do ar no interior de estufas plásticas. In: CONGRESSO BRASILEIRO DE AGrometeorologiA, 10, Piracicaba, SP, 1997. Anais. Piracicaba: Sociedade Brasileira de Agrometeorologia. p. 471-472, 1997. (13 a 18 jul. 1997).

BURN, R.; LAGIER, I. A new greenhouse structure adapted to mediterranean growing. Acta Horticulturae, v. 170, p.37-46, 1985.

CAMACHO, M. J.; ASSIS, F. N.; MARTINS, S. R.; MENDEZ, M. E. G. Avaliação de elementos meteorológicos em estufa plástica em Pelotas (RS). Revista Brasileira de Agrometeorologia, v.3, n.1, p.19-24, 1995.

CERMEÑO, Z. S. Construccion de invernaderos. Madrid: Mundi-Prensa, 1994. 445p. 
CUNHA, R.C.; BERGAMASCHI, H.; BERLATO, M. A.; MATZENAUER, R. Balanço de energia em cultura de milho. Revista brasileira de agrometeorologia, v.4, p.1-14, 1996.

FANG, W. Greenhouse cooling in subtropical regions. Acta Horticulturae, v. 399, p.37-48, 1995.

FARIA JÚNIOR, M. J.; SENO, S.; ARAÚJO, J. A. C.; BORRMANN, E. G. V.; YOSHIDA, E. S. Avaliação de cultivares de alface e de dois modelos de estufa com cobertura plástica, durante o verão, em Ilha Solteira-SP. Cultura Agronômica, v.2, n.1, p.119-128, 1993.

FARIAS, J. R. B.; BERGAMASCHI, H.; MARTINS, S. R.; BERLATO, M. A.; OLIVEIRA, A. C. B. Alterações na temperatura e umidade relativa do ar provocadas pelo uso de estufa plástica. Revista Brasileira de Agrometeorologia, , v.1, n.1, p.51-62, 1993.

FEHR, R. L.; PRIDDY, K. T.; McNEILL, S. G. Limiting swine stress with evaporative cooling. Livestock Environment II, Ames, Iowa. P.577-84, 1982.

FERNANDES, A. L. T. Monitoramento da cultura de crisântemo em estufa através do uso de lisímetro e estação agrometeorológica automatizados. Piracicaba, 1996. 96p. Dissertação (Mestrado) - Escola Superior de Agricultura "Luiz de Queiroz", Universidade de São Paulo.

FEUILLOLEY, P.; MEKIKDJIAN, Ch.; SEVILA, F. Static aeration in greenhouses. Acta Horticulturae, v.281, p.175-182, 1990.

FILGUEIRA, F. A. R. Manual de olericultura: Cultura e comercialização de hortaliças. 2ed. São Paulo: Ed. Agronômica Ceres, 1982. 357p. 
FOlEGATTI, M. V.; SCATOLINI, M. E.; PAZ, V. P. S.; PEREIRA, A. R.; FRIZZONE, J. A. Efeitos da cobertura plástica sobre os elementos meteorológicos e evapotranspiração da cultura de crisântemo em estufa. Revista Brasileira de Agrometeorologia, v.5, n.2, p.155-163, 1997.

FRANCESCANGELI, N.; FERRATO, J.; ROSANIA, A.; LEVIT, H. Efecto del branqueado, sombreado y aspersion de água sobre techo, en la temperatura y otros parametros climáticos en invernaderos, durante el período estival. Acta Horticulturae, v. 357, p.269-294, 1994.

FURLAN, R.A.; SILVA, F.C.da; FOLEGATTI, M.V.. Avaliação do controle de temperatura no interior de ambientes protegidos através de nebulização. In: CONGRESSO BRASILEIRO DE AGROMETEOROLOGIA E ENCONTRO LATINOAMERICANO DE AGROMETEOROLOGIA. Florianópolis, 1999. /Resumo em CBA 99 CD-ROM. (19 a 23 jul. 1999).

GOTO, R. Estufas plásticas: Manejo. In: KEIGO, M.; IAMAMOTO, M. M.; RICCI, A. P. SEALQ: Manejos alternativos na agricultura. Piracicaba: ESALQ, 1993. p. $1-27$.

HANAN, J.J.; HOLEY, W.D.; GOLDSBERRY, K.L. Greenhouse manegement, Berlim: Springer-Verlag, 1978. 530p.

KAI, E. S.; SILVA, I. O. da; PIEDADE, S. M. Avaliação do sistema de ventilação natural com o uso de janela zenital no condicionamento térmico de estufas. . In: CONGRESSO BRASILEIRO DE OLERICULTURA. 40; CONGRESSO IBEROAMERICANO SOBRE UTILIZAÇÃO DE PLÁSTICO NA AGRICULTURA. 2; SIMPÓSIO LATINO-AMERICANO DE PRODUÇÃO DE PLANTAS MEDICINAIS, AROMÁTICAS E CONDIMENTARES, 1. São Pedro, SP. 2000. Anais. São Pedro: Revista da Sociedade de Olericultura do Brasil. v. 18, suplemento, julho, p. 238-239, 2000. 
KITTAS, C. A simple climagraph for characterizing regional suitability for greenhouse cropping in Greece. Agricultural and Forest Meteorology, v. 78, p. 133-141, 1996.

KITTAS, C.; BOULARD, T.; PAPADAKIS, G. Greenhouse ventilation rates through combined roof and side openings: An experimental study. Acta Horticulturae, v. 443, p.31-38, 1997.

LANDSBERG, J. J.; WHITE, B.; THORPE, M. R. Computer analysis of the efficacy of evaporative cooling for glasshouses in high energy environments. Journal Agriculture Engineering Resource. v.24, p.29-39, 1979.

LOURENZO MÍNGUEZ, P. Los determinantes microclimáticos de la horticultura intensiva em el sur mediterrâneo. In: Tecnologia de invernadero II. Almeria: FIAPA, 1998. p.25-44.

MARTIN, E.C.; NOVOA, A. C.; GOMES, S. J. Estudio comparativo de las propriedades de diversos materiales utilizados como cobertura en cultivos protegidos. Revista de Plásticos Modernos, Espanha, v.308, p.185-9, 1982.

MARTIN, E. C.; ROBLEDO, L. V. Aplication de los plásticos en la agricultura. Madrid, Mund-Pressa, 1981, 55p.

MARTINS, S.R. Desafios da plasticultura brasileira: limites sócio-econômicos e tecnológicos frente as novas e crescentes demandas. Horticultura Brasileira, v.14, n.2. p.133-138, nov. 1996.

MILLS, P.J.W.; SMITH, I.E.; MORAIS, G. A greenhouse design for a cool subtropical climate with winters based on microclimatic measurements of protected environments. Acta Horticulturae, v. 281, p.83-93, 1990.

MONTERO, J. I. ; CASTILLA, N.; GUTIERREZ de RAVÉ, E.; BRETONES, F. Climate under plastic in the Almeria. Acta Horticulturae, v.170, p.227-234, 1985. 
MONTERO, J. I.; ANTÓN, A.; BIEL, C.; FRANQUET, A. Cooling of greenhouse with compressed air fogging nozzles. Acta Horticulturae, v. 281, p.199-209, 1990.

MONTERO, J. I.; ANTÓN, A. Greenhouse cooling during warm periods. Acta Horticulturae, v. 357, p.49-61, 1994.

PEREIRA, R. P.; VILLA NOVA, N. A.; SEDIYAMA, G. C. Evapo(transpi)ração. Piracicaba: FEALQ, 1997. 183p.

PEZZOPANE, J. E. M. Uso de estufa com cobertura plástica e de quebra ventos na produção de porta-enxertos de seringueira, na região de Campinas, S.P. Piracicaba, 1994. 86p. (Mestrado) - Escola Superior de Agricultura "Luiz de Queiroz", Universidade de São Paulo.

ROBLEDO DE PEDRO, F. Laminas de polietileno y copolimero EVA para usos en agricultura. Hojas Divulgadoras, Madrid, n 2, 1987. 20p.

ROBledo De PEDro, F.; VICENTE, L.M. Aplicación de Los Plasticos en la Agricultura. 2ed., Madrid, Mundi-Prensa, 1988.573p.

SEEMAN, J. Greenhouse Climate. Agrometeorology, p. 165-178, 1979.

SIMMONS, J. D.; LOTT, B. D. Evaporative cooling performance resulting from changes in water temperature. American Society of Agricultural Engineers, v.12, n.2, p.497-500, 1996.

SIQUEIRA, C. E. M. Propriedades óticas dos filmes agrícolas. In: AEASP. Programa de plasticultura para o Estado de São Paulo. Apostila. São Paulo, 1994. 36 p.

SIQUEIRA, C. E. M. A importância dos materiais plásticos na agricultura do Brasil e do mundo. In: AEASP. Programa de plasticultura para o Estado de São Paulo. Apostila. São Paulo, 1996. 109p. 
TAPIA, G. J. Filmes térmicos para invernaderos. Revista de los plásticos modernos, v.295, p. 75-82, 1981.

TRIKI, J.; VERLODT, H.; BAETEN, S. Influence de differents systemes d'aeration sur la distribution des temperatures sous serre polyethylene. Acta Horticulturae, v. 154, p.241-248, 1984.

VANHOUTTE, S.; VERLODT, H. Comparison of polynomial regression and linear interpolation as methods for temperature distribution studies under greenhouses. Acta Horticulturae, v.281, p.211-229, 1990.

VECCHIA, P. T. D.; KOCH, P. S. História e perspectivas da produção de hortaliças em ambiente protegido no Brasil. Informe Agropecuário, v.20, n.200/201, p.5-10, set./dez. 1999.

VERHEYE, Ph.; VERLODT, H. Comparison of different systems for static ventilation of hemispheric plastic greenhouses. Acta Horticulturae, v.281, p.183-197, 1990.

VILlA NOVA, N.A.; OMETTO, J. C.; SALATI, E. Aspectos termodinâmicos da atmosfera. Piracicaba: CENA/ESALQ, 1972. 24p. (Boletim didático, n.06).

WHITAKER, J. H. Agricultural building and structure. Heston Publishing Company, Heston, Virginia, 1979.

WIERSMA, F.; SHORT, T. H. Evaporative cooling. In: HELLICKSON, M. A.; WALKER, J. N. Ventilation of agricultural structures. ASAE, 1983. p.103-118. 